\title{
3D P- and Converted Shear wave characteristics of the Morrow production trend in the Buffalo Valley field, Chaves-Eddy County, New Mexico
}

Sandeep Pyakurel

West Virginia University

Follow this and additional works at: https://researchrepository.wvu.edu/etd

\section{Recommended Citation}

Pyakurel, Sandeep, "3D P- and Converted Shear wave characteristics of the Morrow production trend in the Buffalo Valley field, Chaves-Eddy County, New Mexico" (2005). Graduate Theses, Dissertations, and Problem Reports. 2231.

https://researchrepository.wvu.edu/etd/2231

This Thesis is protected by copyright and/or related rights. It has been brought to you by the The Research Repository @WVU with permission from the rights-holder(s). You are free to use this Thesis in any way that is permitted by the copyright and related rights legislation that applies to your use. For other uses you must obtain permission from the rights-holder(s) directly, unless additional rights are indicated by a Creative Commons license in the record and/ or on the work itself. This Thesis has been accepted for inclusion in WVU Graduate Theses, Dissertations, and Problem Reports collection by an authorized administrator of The Research Repository @ WVU. For more information, please contact researchrepository@mail.wvu.edu. 


\title{
3D P- and Converted Shear wave characteristics of the Morrow production trend in the Buffalo Valley field, Chaves-Eddy County, New Mexico
}

\author{
Sandeep Pyakurel \\ Thesis submitted to the \\ Eberly College of Arts and Sciences at West Virginia University \\ in partial fulfillment of the requirement for the degree of \\ Master of Science in Geology
}

\section{Committee}

Dr. Tom Wilson, Ph.D., Dept. of Geology and Geography (Chair)

Dr. Jaime Toro, Ph.D., Dept. of Geology and Geography

Dr. Dave Oldham, Ph.D., Dept. of Geology and Geography

Department of Geology and Geography

Morgantown, West Virginia

2005

Keywords: 3d seismic, Buffalo Valley field, converted shear wave, Morrow play, Atoka, Morrow, Seismic inversion, Poisson's ratio, vp/vs ratio, acoustic impedance 


\begin{abstract}
3D P- and Converted Shear wave characteristics of the Morrow production trend in the Buffalo Valley field, Chaves-Eddy County, New Mexico
\end{abstract} Sandeep Pyakurel

Regional and local subsurface log and 3D seismic interpretations were undertaken in the vicinity of the Buffalo Valley field in southeastern New Mexico. Oil production in the field is trapped in early Pennsylvanian basal Morrow Formation Harris Channel. Regional interpretation shows that the field is located on the Northwestern Shelf along the rim of the Delaware basin. Structure and isopach maps reveal that high production is associated with a structural low that actively developed during deposition of the reservoir interval. The Harris Channel scoured into the upper Mississippian Barnett shale. Areas of thin Barnett Shale coincide with production and define the channel course.

Seismic data from the field consisted of 24 square miles of 3D P-wave and mode converted shear wave (PS-wave) data collected by WesternGeco. The 3D seismic interpretation reveals that the field is bounded by steeply dipping north-south trending faults along its west and east margins. Dip reversals along these faults suggest they may be strike-slip in origin. The 5 to 30 foot thickness of the Harris Channel lies below the resolution limit (60 feet) of the P-wave seismic and does not produce an easily detectable seismic response. Recursive inversions of the P and PS-wave volumes were combined to provide 3D Vp/Vs and Poisson's ratio volumes. Poisson's ratios were averaged over a $5 \mathrm{~ms}$ window of time including reflection events from the reservoir interval. Poisson's ratio/lithology relationships were derived from a well in the field. The mapped distribution of Poisson's ratio throughout the survey helps define the distribution of producing sands. 


\section{ACKNOWLEDGEMENT}

I would have never accomplished this research within short time frame (20042005) without the continuous encouragement and support from my advisor Dr. Tom H. Wilson. I'm very much indebted for his guidance and advice in every step of difficult moments for the completion of this research, especially during the time when my daughter "Shrina" was born. I also want to thank him for providing a chance for publication in the GSA annual meeting 2004 at Denver, Colorado.

I'm also grateful to Dr. Jaime Toro being part of my committee member and his never ending guidance and feedback on my thesis.

Dr. Dave Oldham who is also my committee member has helped me considerably with the well log interpretations and hands on GeoGraphix use. I'm indebted by his effort as he was always available to discuss technical issues and helped to solve them.

I also want to thank Dr. Robert Shumaker for discussing problems related to the fault interpretation and the helpful papers he provided.

I'm also grateful to Department of Geology and Geography, University of West Virginia for the education and experience I’ve received during my MS. Program.

Appreciation is extended to WesternGeco for providing the 3D seismic data used in this study. This research would not have been possible without their support. This work was also supported in part through U. S. Department of Energy. NETL contract DE-FC26-03NT41629 and through a teaching assistantship with the Department of Geology and Geography.

Software used in this research included Seismic Micro-Technology, Inc.'s Kingdom Suite software (used for 3D seismic interpretation and analysis) and Landmark Graphics GeoGraphix Discovery Suite software (used to compile subsurface interpretations from well log data).

I'm also thankful to my colleagues and friends for helping to resolve technical issues encountered during the preparation of this thesis.

Last but not the least; I want to thank my wife Archana and my family for their continuous support and encouragement to accomplish the research. 


\section{TABLE OF CONTENTS}

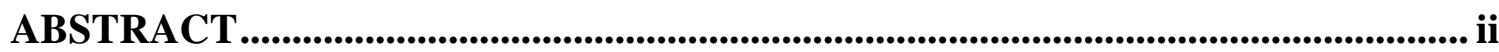

ACKNOWLEDGEMENT....................................................................................................iii

TABLE OF CONTENTS ....................................................................................................iv

TABLE OF FIGURES..............................................................................................................vi

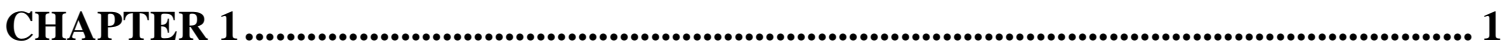

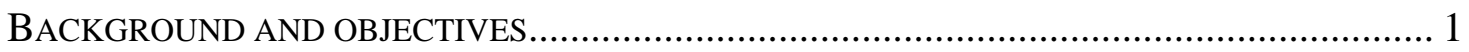

1.1 General Background ..................................................................................... 1

1.2 Purpose and Objective ................................................................................ 2

1.3 Location .................................................................................................. 2

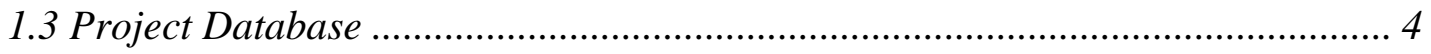

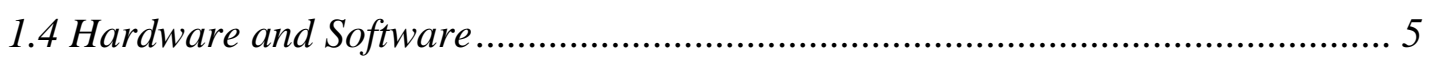

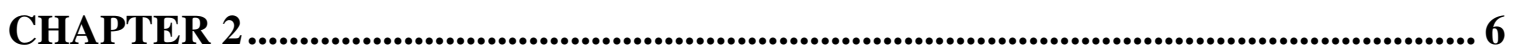

Geological SETTING AND PReVIOUS WorKS............................................................... 6

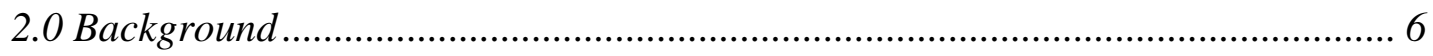

2.1 Geological Setting and Tectonic history of the area ............................................ 7

2.2 Basin Evolution and Sedimentation ................................................................. 11

2.3 Stratigraphy ……………………………………..................................... 13

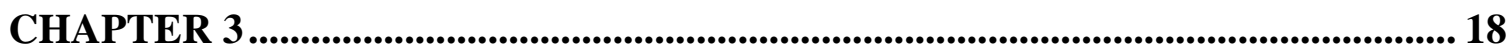

REGIONAL AND LOCAL GEOLOGY FROM WELL LOGS ................................................... 18

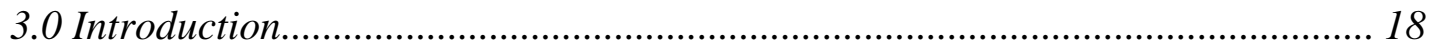

3.1 Well log Characteristics for the Atoka-Morrow interval...................................... 18

3.2 Structure in terms of the Regional Setting ............................................................. 23

3.3 Local Structure within the Buffalo Valley field................................................... 28

3.3.1 Chester Formation (Upper Mississippian interval) …………………………….... 28

3.3.2 Atoka Formation......................................................................................... 37

3.3.3 Strawn Formation ...................................................................................... 41 


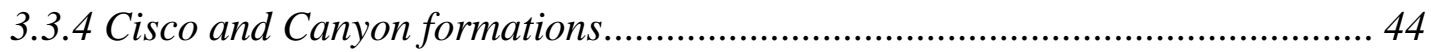

3.3.5 Wolfcamp Formation and Glorietta formations ….................................................. 48

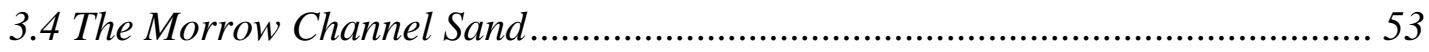

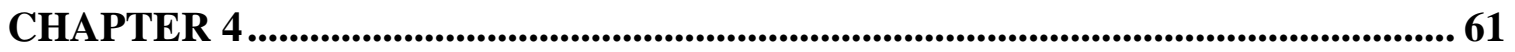

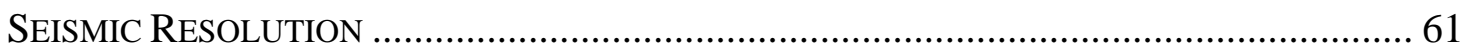

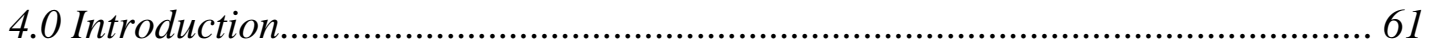

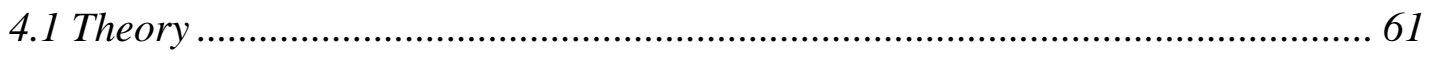

4.2 Resolution of the Atoka-Morrow Interval ...................................................... 66

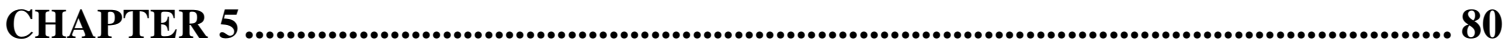

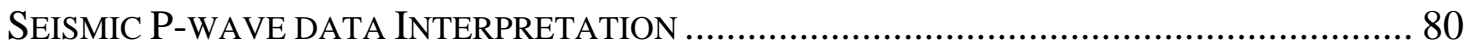

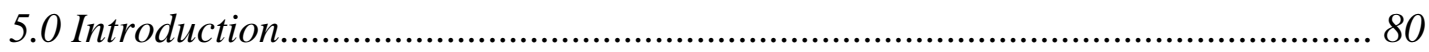

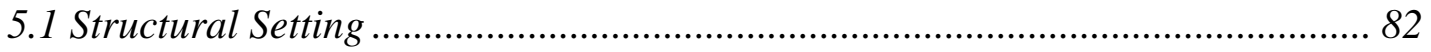

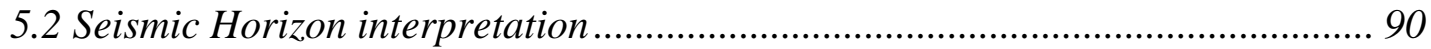

5.2.1 Mississippian Chester Horizon................................................................................. 90

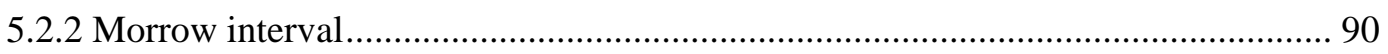

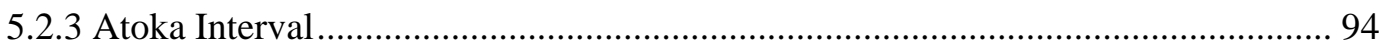

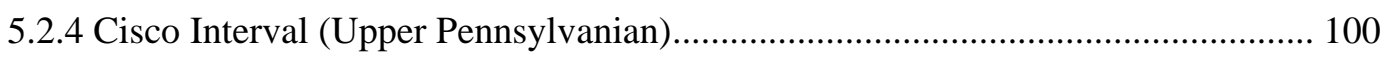

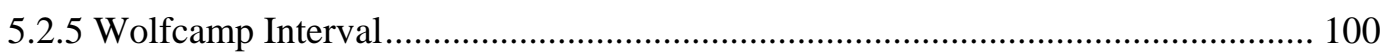

5.3 Seismic attributes and time Slice Interpretation .......................................... 108

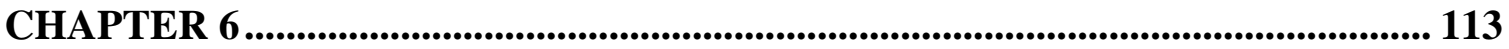

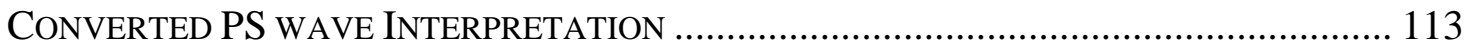



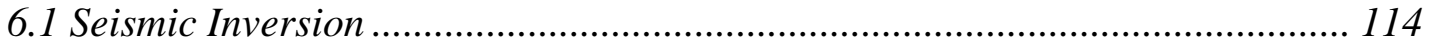

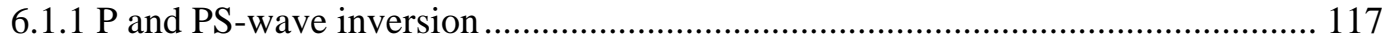



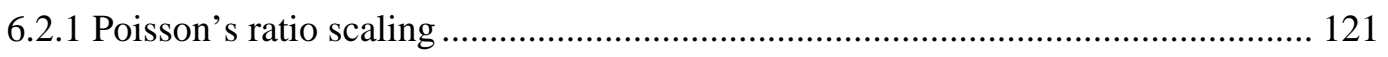

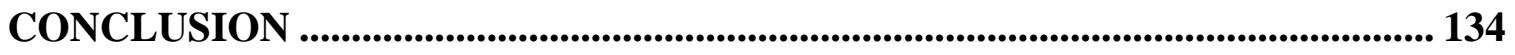

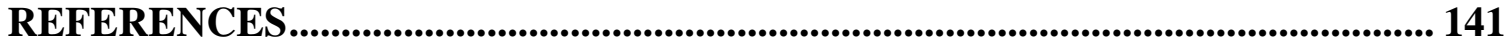




\section{TABLE OF FIGURES}

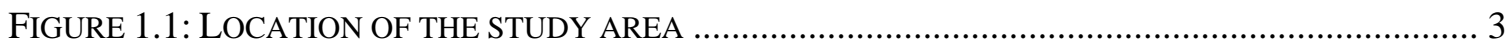

FIGURE: 1.2 LOCATION OF THE SEISMIC SURVEY AREA BUFFALO VALLEY .................................. 3

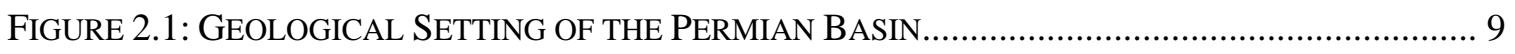

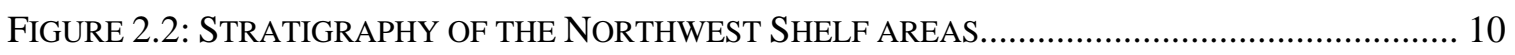

Figure 2.3: TECTONIC HISTORY OF THE DELAWARE BASIN AND ITS PREDECESSOR TOBOSA

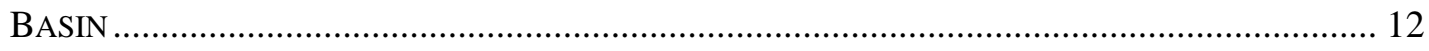

FIGURE 2.4: INTERPRETED DEPOSITIONAL ENVIRONMENT IN THE SOUTHEASTERN NEW MEXICO

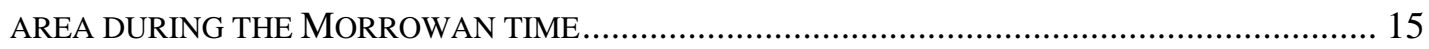

Figure 3.1: Typical GAMMA RAY AND DENSITy RESPONSES OF THE ATOKA-Morrow

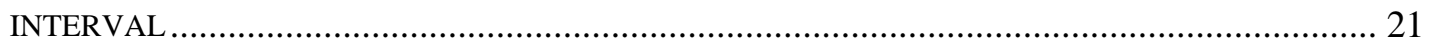

FIGURE 3.2: TOWNSHIPS WITH WELL LOCATIONS USED IN THE REGIONAL STUDY....................... 25

FigURE 3.3: SUBSEA STRUCTURE MAP ON TOP OF THE CHESTER FORMATION. ........................... 25

Figure 3.4 : Precambrian basement configuration of the New MeXico-West TeXas

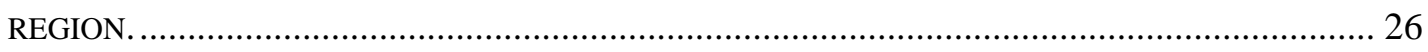

FIGURE 3.5: SUBSEA STRUCTURE ON THE TOP OF THE ATOKA FORMATION. ................................ 27

FIGURE 3.6: ISOPACH OF THE ATOKA-MORROW INTERVAL....................................................... 29

FigURE 3.7: SEMINOLE TYPE ANTICLINE ON THE NORTHWEST SHELF...................................... 29

FiguRE 3.8 : SUbSEA STRUCTURE MAP ON THE TOP OF THE CHESTER FORMATION ..................... 31

FIGURE3.9: $2^{\mathrm{ND}}$ ORDER STRUCTURAL TREND MAP OF THE CHESTER FORMATION ........................ 32

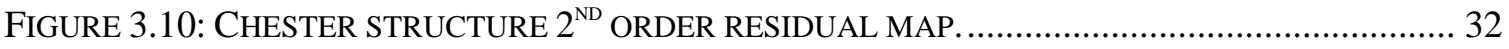

FiguRE 3.11: STRUCTURE ON TOP OF THE CHESTER FORMATION FROM ROSWELL GEOLOGICAL

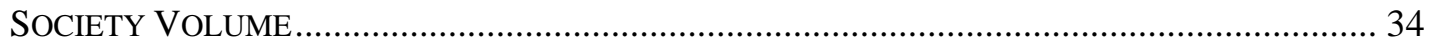

FIGURE 3.12: LINES SHOWING THE CROSS-SECTION LOCATION WITHIN THE SEISMIC SURVEY AREA 34 
FIGURE 3.13: STRUCTURAL CROSS -SECTION ROUGHLY ALONG THE STRIKE............................. 35

FIGURE 3.14: STRUCTURAL CROSS -SECTION ROUGHLY ALONG THE DIP................................... 36

FigURE 3.15 : SUBSEA STRUCTURE ON THE TOP OF THE ATOKA FORMATION............................. 38

FIGURE 3.16: SECOND ORDER RESIDUAL STRUCTURE ON TOP OF THE ATOKA.............................. 39

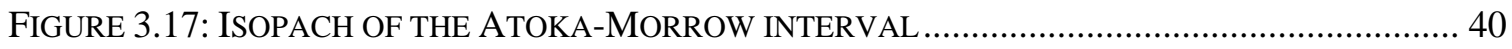

FIGURE 3.18: SUBSEA STRUCTURE MAP ON THE TOP OF THE STRAWN FORMATION.................... 42

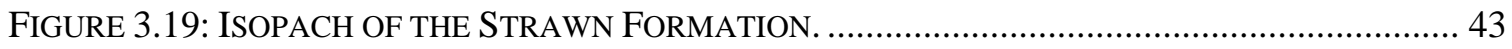

FIGURE 3.20: SUBSEA STRUCTURE ON TOP OF THE CISCO FORMATION. ..................................... 45

FIGURE 3.21: ISOPACH FROM THE TOP OF THE CISCO FORMATION TO TOP OF THE STRAWN

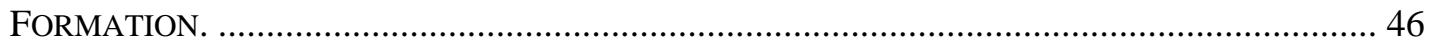

FiguRE 3.22: ISOPACH OF THE PENNSYLVANIAN INTERVAL INCLUDING THE BARNETT SHALE... 47

FIGURE 3.23: SUBSEA STRUCTURE ON TOP OF THE WOLFCAMP FORMATION................................. 49

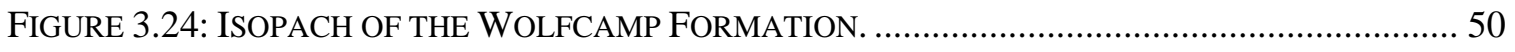

FIGURE 3.25: STRUCTURE ON TOP OF THE GLORIETTA FORMATION.......................................... 51

FIGURE 3.26: ISOPACH OF THE TOP OF THE GLORIETTA-TO-TOP OF THE WOLFCAMP INTERVAL.. 52

FiguRE 3.27: YEARLY PRODUCTION FIGURES FOR THE SELECTED WELLS IN THE BUfFALO



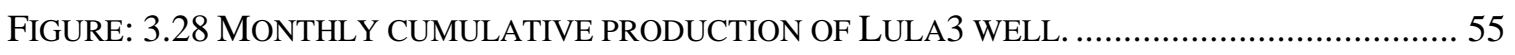

FIGURE 3.29: FIVE YEAR CUMULATIVE OIL PRODUCTION MAP.................................................. 56

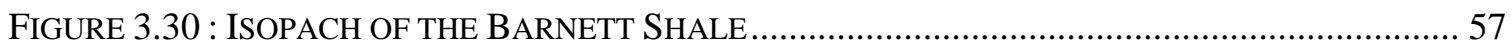

FIGURE 3.31: VECTOR OVERLAY OF BARNETT SHALE THINNING OVER THE HIGH PRODUCTION

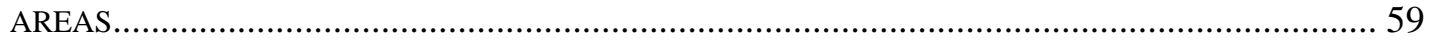

FiguRE 3.32: POLYGON OVERLAY OF BARNETT THIN ON THE 2ND DERIVATIVE CHESTER

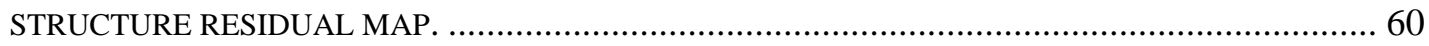

FIGURE 3.33: OVERLAY OF HIGH PRODUCTION AREAS ON THE CHESTER STRUCTURE MAP. .......... 60

FIGURE 4.1: AMPLITUDE SPECTRUM SHOWING AMPLITUDE VERSUS FREQUENCY......................... 63 
FIGURE 4.2: THE DOMINANT PERIOD $\tau_{\mathrm{D}}$ DERIVED FROM THE ZERO PHASE WAVELET. 63

FIGURE 4.3: RELATIONSHIP OF FRESNEL ZONE RADIUS TO DEPTH AND FREQUENCY 65

FIGURE 4.4A: AMPLITUDE SPECTRUM GENERATED FOR THE P-WAVE DATA................................. 68

FIGURE 4.4B: AMPLITUDE SPECTRUM GENERATED FOR THE PS-WAVE DATA............................... 68

FIGURE 4.5: COMPARISON SEISMIC RESPONSE IN A TIME WINDOW EXTENDING FROM 0.95 TO 1.15 SECONDS: FOR THE P-WAVE AND PS-WAVE DATA.

FIGURE 4.6 : LOGS ILLUSTRATING GEOPHYSICAL PROPERTIES OF THE LOWER PENNSYLVANIAN AND UPPER MISSISSIPPIAN STRATA PENETRATED IN THE LULA 3 WELL................................. 70

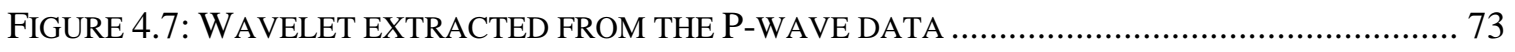

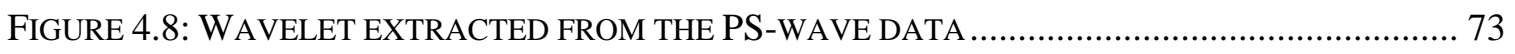

FIGURE 4.9: RESOLUTION CALIBRATION CURVE FOR THE P-WAVE WAVELET ............................... 74

FIGURE 4.10: RESOLUTION CALIBRATION CURVE FOR THE PS-WAVE WAVELET......................... 76

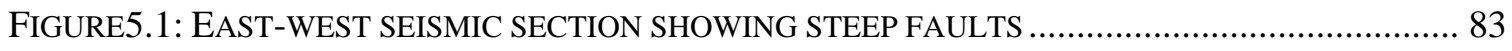

FIGURE 5.2: EAST-WEST SEISMIC SECTION WITH STEEP VERTICAL FAULTS AND FLOWER

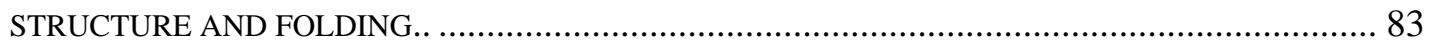

Figure 5.3: TIME STRUCTURE ON THE CHESTER REFLECTION EVENT WITH 3D PERSPECTIVE VIEW 84

FIGURE 5.4 : 3D VIEW OF THE WESTERN AND EASTERN BORDER FAULTS IN THE BUFFALO VALLEY FIELD. 85

FIGURE 5.5: TIME STRUCTURE ON THE BOUNDARY FAULTS 87

FIGURE 5.6: PLAN VIEW OF A TYPICAL STRIKE SLIP FAULT SHOWING DIP REVERSALS. 87

FIGURE5.7: PRECAMBRIAN NORTH-SOUTH TRENDING BASEMENT FAULT ZONE. 88

FiguRE 5.8: Time STRUCTURE ON THE MORROW REFLECTION EVENT WITH 3D PERSPECTIVE VIEW 91

FIGURE 5.9: ISOPACH OF THE MORROW-TO-CHESTER LIMESTONE INTERVAL. 93 
FIGURE 5.10 : VECTOR OVERLAY OF THINNED BARNETT SHALE ON ISOPACH OF THE MORROW

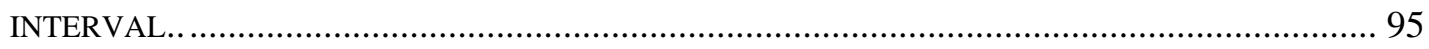

FIGURE 5.11: TIME STRUCTURE ON THE ATOKA REFLECTION EVENT WITH 3D PERSPECTIVE VIEW 96

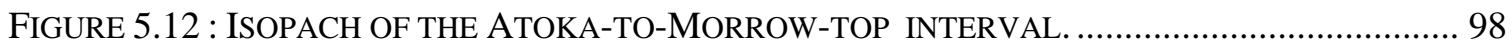

FIGURE 5.13: ISOCHRON OF THE TOP OF THE ATOKA-TO-TOP OF THE CHESTER INTERVAL. ....... 99

FiguRE 5.14 : TIME STRUCTURE ON THE CisCO REFLECTION EVENT WITH 3D PERSPECTIVE

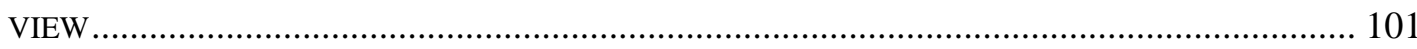

FIGURE 5.15 : ISOCHRON OF THE CISCO THROUGH STRAWN INTERVAL. .................................... 102

FIGURE 5.16: TIME STRUCTURE ON THE WOLFCAMP REFLECTION EVENT WITH 3D PERSPECTIVE VIEW 103

FIGURE 5.17: ISOCHRON OF THE TOP OF THE WOLFCAMP-TO-TOP OF THE CISCO REFLECTION EVENT WITH 3D PERSPECTIVE VIEW 104

FIGURE 5.18: COMPARISON OF TIME STRUCTURE ON THE CHESTER THROUGH WOLFCAMP REFLECTION EVENTS 106

FIGURE 5.19: ISOCHRON OF THE GLORIETTA-ABO INTERVAL 107

FIGURE 5.20 : AAV AMPLITUDE IN A TIME WINDOW THAT EXTENDS FROM 6 TO 10 MS BELOW THE MORROW REFLECTION EVENT. 110

FIGURE 5.21: INTEGRATED AMPLITUDE IN A TIME WINDOW EXTENDING FROM 20 TO 27 MS BELOW THE ATOKA TOP. 110

FIGURE 5.22: INTEGRATED AMPLITUDE CALCULATED FOR A 10 MS WINDOW OF TIME EXTENDING DOWN FROM THE MORROW TOP 112

FIGURE 5.23: INTEGRATED AMPLITUDE MAP CALCULATED FOR A 20 MS WINDOW OF TIME EXTENDING UP FROM THE CHESTER TOP 112

FIGURE 5.24: RMS ACOUSTIC IMPEDANCE CALCULATED FOR A WINDOW OF TIME EXTENDING FROM 10 MS BELOW THE TOP OF THE ATOKA TO 9MS BELOW THE MORROW TOP. 112 
FIGURE 6.1: EAST-WEST SEISMIC LINE FROM THE P-WAVE 3D DATA VOLUME.

FIGURE 6.2: EAST-WEST SEISMIC LINE FROM THE PS-WAVE 3D DATA VOLUME 115

FiguRE 6.3: ACOUSTIC IMPEDANCE CALCULATED FOR THE PS-WAVE DATA ALONG AN E-W LiNE

FiguRE 6.4: ACOUSTIC IMPEDANCE CALCULATED FOR THE P-WAVE DATA ALONG AN E-W LINE 118

FIGURE 6.5: MAP VIEW SHOWING VARIATIONS IN THE AVERAGE P-WAVE ACOUSTIC IMPEDANCE WITHIN A 5 MILLISECOND WINDOW OF DATA EXTENDING FROM 5 MS TO 10 MS BELOW THE MORROW REFLECTION EVENT.. 119

FIGURE 6.6: MAP VIEW SHOWING VARIATIONS IN THE AVERAGE PS-WAVE ACOUSTIC IMPEDANCE IN A 5 MILLISECOND WINDOW OF DATA EXTENDING FROM 5 MS TO 10 MS BELOW THE MORROW REFLECTION EVENT.. 119

FiguRE 6.7: VP/VS RATIO COMPUTED FROM THE INVERTED P-WAVE AND PS-WAVE DATA VOLUME IN A 5 MILLISECOND WINDOW OF DATA EXTENDING FROM 5 MS TO 10 MS BELOW THE MORROW REFLECTION EVENT. 120

FIGURE 6.8: POISSON'S RATIOS COMPUTED FROM THE 3D IMPEDANCE VOLUME PRIOR TO SCALING 122

FIGURE 6.9: VP/VS AND POISSON'S RATIO PLOT FROM THE VELOCITY LOG IN THE LULA 3 WELL

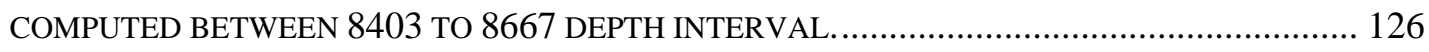

FiguRE 6.10: VP/VS AND POISSON'S RATIOS CALCULATED FROM THE VELOCITY LOGS IN THE LULA 3 WELL 127

FIGURE 6.11: POISSON'S RATIOS FOR CLASTIC SEDIMENTS RANGING FROM NEAR-SURFACE WEATHERED ZONES TO GAS SANDS VERSUS VP/VS RATIO. 128

FIGURE 6.12: HiSTOGRAM OF POISSON’S RATIOS AFTER SCALING 128

Figure 6.13: PRE-SCALED AND POST-SCALED TRACE RESPONSES COMPARION FROM THE EXTRACTED 3D POISSON'S RATIO VOLUME. 130 


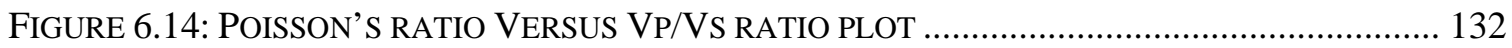

Figure 6.15: AVERAge OF THE POISSON'S RATIO BETWEEN 5-10 MS INTERVAL BELOW THE MORROW REFLECTION EVENT . 132 


\section{CHAPTER 1}

\section{BACKGROUND AND OBJECTIVES}

\subsection{General Background}

The Delaware basin in southeastern New Mexico has been a prolific hydrocarbon producer. Production from the Pennsylvanian Morrow reservoir began in the late 1960's. There are approximately 269 pools in southeastern New Mexico that produced oil and gas from the Morrow reservoir, (Mazzullo, 2001). These reservoirs are problematic due to the stratigraphic, structural and diagenetic complexity of the individual sand traps. Such complexities have made effective exploration and production difficult leaving the Morrow Play underdeveloped, (Mazzullo, 2001). Therefore the Morrow Play offers significant opportunity to discover additional reserves.

In order to characterize and understand this deep seated hydrocarbon rich reservoir, the seismic properties, well log responses and the detailed subsurface geology of the area must be known. The research undertaken in this study incorporates detailed interpretation of 3D seismic reflection data from the Buffalo Valley oil field in southeastern New Mexico. Oil is produced from lower Morrow channel sand known as the Harris Channel. The emphasis of this study is on an assessment of the possible linkages between seismic response and oil production. 3D seismic data used in this study were provided by WesternGeco. The survey covers the central part of the field. Donated data included zero-offset and 3D VSP's and a dipole sonic from a key well (the Lula 3 well) located within the 3D survey area. The study also incorporates interpretation of the converted mode shear waves (PS waves) recorded and processed as a separate 3D 
volume. Methods are developed and tested to extract Poisson's ratio and lithology information from the combined analyses of both P and PS-wave volume.

\subsection{Purpose and Objective}

The main purpose of this thesis is to provide a detailed interpretation of the Morrow reservoir using 3D seismic data including, both P-wave and PS-wave volumes, collected in the Buffalo Valley field, southern Chavez County, NM. The study is also coupled with well log data analysis. The specific objectives are i) Interpretation and analysis of the 3D seismic data volume, ii) Evaluation of the attributes of the P-wave (compressional wave) and PS-wave (converted shear wave) data sets and their relationships to the log observation, iii) Regional geologic characterization of the area surrounding the 3D seismic survey based on well log data, and iv) evaluation of the interrelationship between the production, structure and seismic response in the Buffalo Valley field. The seismic data covers part of the 4 township area in southern Chavez County. Combined analysis of P and PS-wave data sets are evaluated for their potential to uncover the productive lower Morrow sand channel known as the Harris Channel. The regional well log interpretation and mapping effort helps define the relationship of the field level structure to regional structure of the area.

\subsection{Location}

The study area is located along the northern part of Eddy County and southern part of Chaves County, New Mexico (Figure 1.1). The study area is geologically located on the Northwest Shelf of the Delaware Basin. The regional study covers an area including 4 townships in Chaves County and 8 townships in Eddy County. 


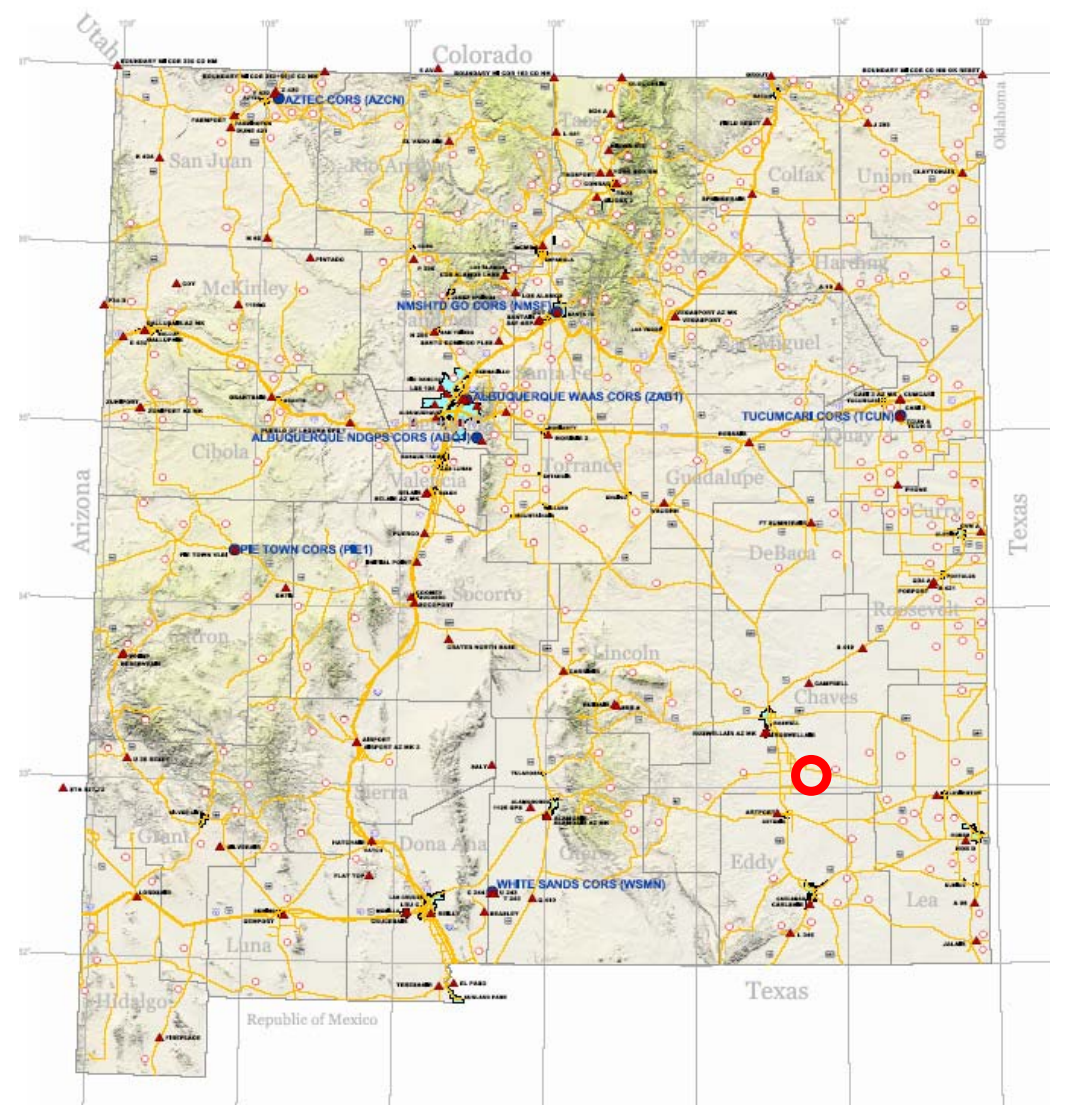

Figure 1.1: Location of the study area

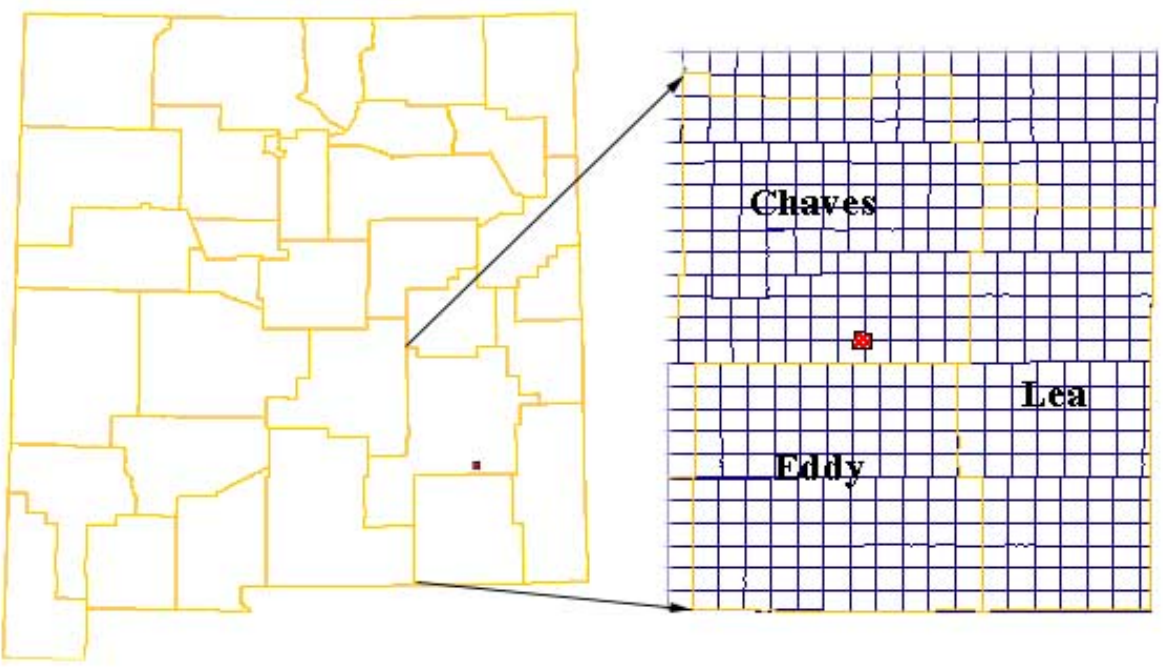

Figure: 1.2 Location of the Seismic survey area Buffalo Valley (red square). 


\subsection{Project Database}

Seismic data provided by WesternGeco cover a 24 square mile area in the heart of the Buffalo Valley field (Figure 1.2). The 3D seismic data were collected using a vibroseis source. Sweep frequencies extended from 8 to $98 \mathrm{~Hz}$ with a sweep length of 17 seconds (Van Dok and Taiser, 2001). Both P-wave and PS-wave data were recorded. P to S wave travel times in the 3D PS-wave data set were corrected to P-wave travel time by WesternGeco to facilitate direct comparison of P-wave and PS-wave data interpretation. The 3D seismic analysis conducted in this thesis incorporates interpretations and comparisons of both the P-wave and PS-wave data volumes.

The project database also includes the well log data in both vector and raster form. Detailed well control in the vicinity of the 3D seismic survey is integrated into the seismic interpretation. Regional well control from an approximately 720 square mile area surrounding the field helps place the Buffalo Valley field into the regional structural context of the Morrow Play located along the Northwest Shelf of the Delaware Basin. A total of 96 wells were used for the construction of regional structure and isopach maps.

Regional geological characterization of the area is based on formation top picks obtained from driller's logs, borehole geophysical logs and digital well header files in TIFF format obtained from the New Mexico Bureau of Geology and Mineral Resources website at http://geoinfo.nmt.edu/resources/petroleum/poolmaps.html. Considerable data were also obtained from the New Mexico Oil and Gas Pool Maps CD, Version 1.0 (2000), New Mexico Bureau of Geology and Mineral Resources (NMBGMR). Additional Tiff images of geophysical logs and well files were obtained from the New Mexico Energy, Minerals and Natural Resources Department Oil Conservation Division at 
http://ocdimage.emnrd.state.nm.us/. Production data were obtained from the New Mexico Tech “Go-Tech” site at http://octane.nmt.edu/data/ongard/. A total of 57 wells are used to characterize variations of 5 yrs cumulative oil production surrounding the 3D survey area.

\subsection{Hardware and Software}

The 3D seismic data were analyzed and interpreted using Seismic-MicroTechnology's Kingdom Suite seismic interpretation software. The software runs on desktop PC with Microsoft Windows operating system. Horizon and fault interpretation, and evaluations of amplitude and various post stack attributes including instantaneous amplitude and impedance were made for P-wave and PS-wave data using Kingdom Suite.

Well log analysis, and the construction of cross-sections, and structure and isopach maps were undertaken using Landmark Graphic Corporation’s GeoGraphix Discovery Suite software package. This package provides a variety of modules that allow the explorationist to create and manage various well and seismic databases, conduct well $\log$ analysis, create structure and isopach maps, and cross-sections. Well log header file information and formation tops were entered into the GeoGraphix WellBase module, maps were created using GeoAtlas, Cross-sections were created in Xsection and Well log analysis was conducted using Prizm. 


\section{CHAPTER 2}

\section{GEOLOGICAL SETTING AND PREVIOUS WORKS}

\subsection{Background}

Very little has been published on the reservoir properties and production distribution within the Morrow sand channels of the Buffalo Valley field. Worthington (1999) described the structure and production of the Atoka-Morrow interval down to the Mississippian unconformity. James (1985) described the depositional environment of the Atoka and Morrow formations about 20 miles south of the Buffalo Valley field. Ota (2001) made a detailed study of the Atoka Formation about 40 miles, west of the study area in the Vacuum field, Lea County, New Mexico.

Recently, Sanchez (2005) developed seismic synthetic models of the Morrow and adjacent Pennsylvanian strata. He described the Buffalo Valley field as bounded by steeply dipping reverse faults along the east and west margins of the field, with a probable strike slip component. These faults moved during deposition of the lower Pennsylvanian units. The Atoka-Morrow interval is interpreted to consist of fluvialdeltaic marine depositional environments (Ota, 2001; Mazzullo, 1995; James, 1985, and Hills and Galley, 1988). Structure maps presented by Sanchez (2005) reveal that the Atoka and Morrow formations have northeast strike and dip to the southeast across the survey area. The Atoka-Morrow interval also thickens to the southeast toward the interior of the Delaware Basin. Models developed by Sanchez indicate that the Morrow channel is too thin to be resolved in the seismic data from the site. 


\subsection{Geological Setting and Tectonic history of the area}

The study area is located along the Northwest Shelf of the Delaware Basin, in the northern part of the Eddy County and southern part of the Buffalo Valley area in Chaves county, New Mexico (Figures 2.1 and 2.1). The Northwest Shelf lies, in general, to the north of the Diablo Platform, Delaware Basin, Central Basin Platform, and Midland Basin (Figure 2.1), Dutton et al. (2004).The Delaware Basin is a major structural subdivision of the Permian Basin. The Delaware Basin is bounded on the southwest by the Diablo Platform uplift and to the east by the Central Basin Platform (Hills and Galley, 1988). The southern part of the basin is bounded by the edge of the Ouachita-Marathon fold belt. The Northwest Shelf lies along the northern and northwest margins of the Delaware Basin. This shelf marks a significant slope break and may overlie deep-seated basement faults (Montgomery, 1999). The Geological setting of the Permian Basin and the study area is shown in Figure 2.1.

Subsidence history of the Delaware Basin is represented by two distinct stages of basin subsidence. The ancient Tobosa Basin is believed to have originated from a Precambrian to early Paleozoic episode of subsidence within the cratonic basement (Casavant, 1999). Shumaker (1992) suggests that the Tobosa Basin may have been the site of Keweenawan mid-continent rifting. Deposition within the Tobosa basin occurred from Ordovician through Devonian time. The Tobosa Basin was segmented by differential uplift and subsidence beginning in the Mississippian. During the late Mississippian relative subsidence along the west and east flanks of the Central Basin Platform formed the Delaware and Midland Basins, respectively. Pennsylvanian and 
Lower Permian strata thicken significantly across the edge of the Central Basin Platform into the Delaware Basin (Shumaker 1992).

The principal stratigraphic units of the Northwest Shelf are shown in the Figure 2.2. The Proterozoic basement rocks consist largely of metamorphic and plutonic rocks of cratonic origin (Hills, 1984), however detailed information about the basement is scant since very few wells have penetrated basement and the cuttings and cores from most of these wells have not been preserved; its lithologic properties and interrelationships are poorly understood (Hills, 1984). Within the Northwest Shelf of the study area Dutton et al. (2004) indicate that most of the Cambrian, middle Ordovician, and nearly all of the Devonian section are missing, suggesting widespread emergence and erosion during evolution of the Tobosa Basin. Within the Delaware Basin and Northwest Shelf areas, there is a relatively continuous succession of Permian through Triassic strata with exception of the missing middle San Andres Formation (mid-Permian) along the Northwestern Shelf (Hills \& Galley, 1988). However, drilling logs from the Buffalo Valley field report penetration of the San Andres. It may be that this unconformity is not as widespread or continuous as reported in earlier studies. The San Andres intervals correlate roughly to the Brushy Canyon Formation in the Delaware Basin (Figure 2.2). 


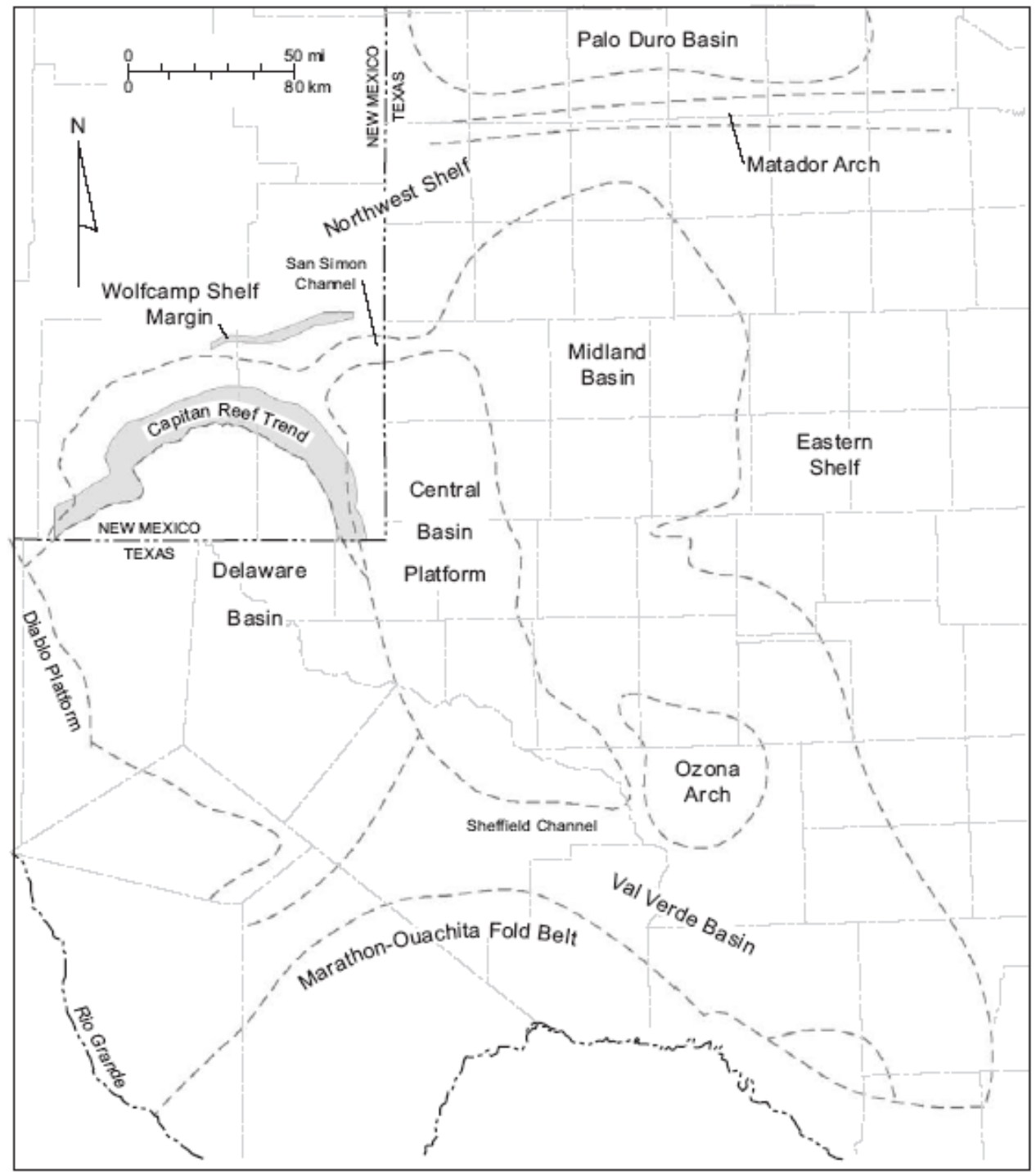

Figure 2.1: Geological Setting of the Permian Basin and the ancient Tobosa basin, from Dutton et. al., 2004. 


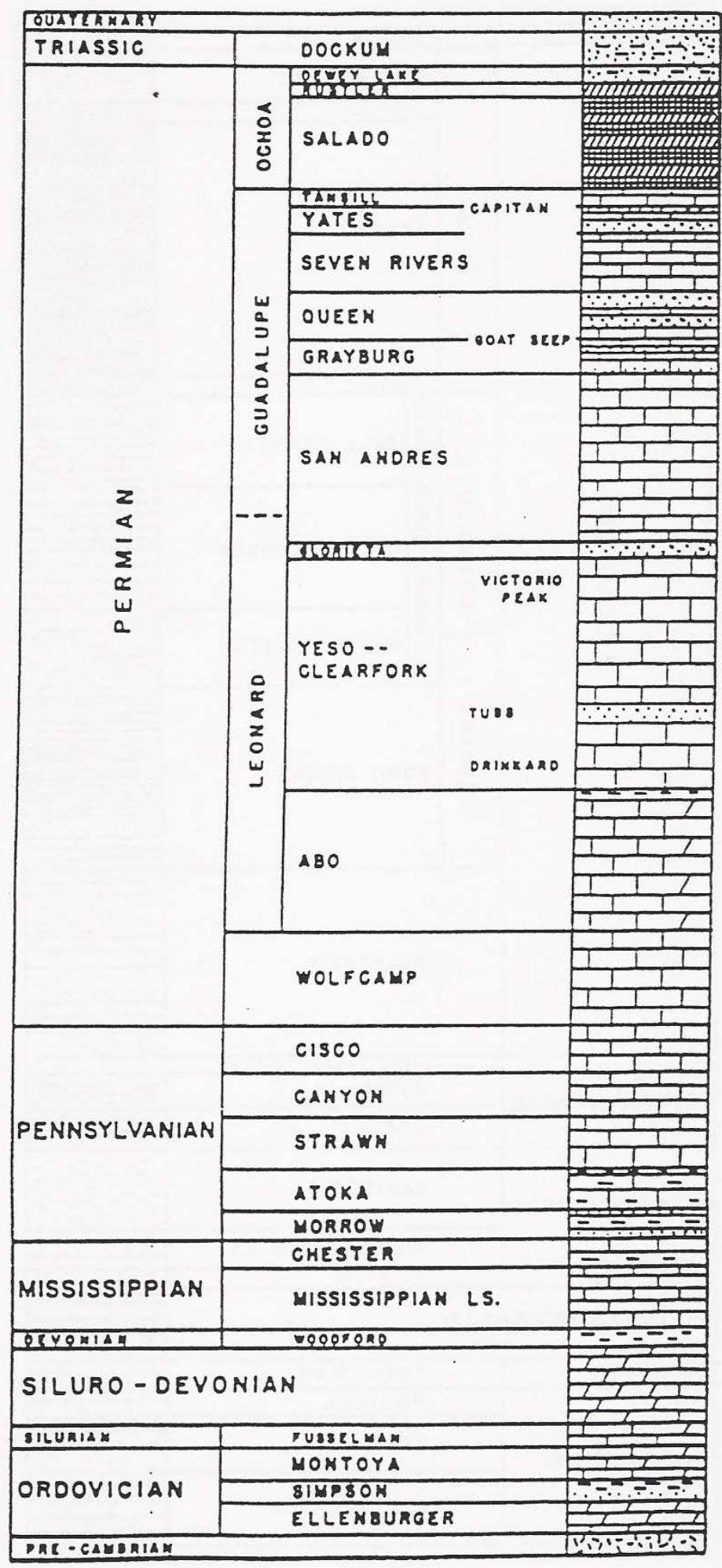

Figure 2.2: Stratigraphy of the Northwest Shelf areas of the Permian Basin from Worthington (1999). Barnett Shale which is discussed and mapped in this study lies between Morrow and Chester formations. 


\subsection{Basin Evolution and Sedimentation}

The Permian Basin, including its present day subdivisions (the Delaware and Midland basins, Central Basin Platform and other smaller sub basins were a contiguous part of the early Precambrian-craton in this region (Hills, 1984). Gradual subsidence throughout much of the Paleozoic formed the shallow Tobosa basin as described by Galley (1958). Subsidence analysis by Yang and Dorobke (1995) suggests that the influence of tectonic loading in the Basin was a minor but significant component. The tectonic history of the Delaware Basin and Northwest Shelf area is shown in Figure 2.3. Sediments deposited in the ancestral Tobosa Basin consisted primarily of carbonate and fine grained clastic sediments associated with shallow water deposition until Mississippian Period (Hills and Galley, 1988). This basin is interpreted to have been a large cratonic embayment that was rimmed by a wide shallow shelf (Hills and Galley, 1988).

During the late Mississippian, the initial collision between the Gondwanaland and Laurasia began in the Marathon - Ouachita area to the south and east of the Tobosa Basin (Hills, 1984). Hills notes that the Tobosa Basin, whose depocenter was located along the present trend of the Central Basin Platform, began to segregate tectonically into the embryonic Midland and Delaware basins forming a mildly deformed chain of islands along the present trend of the Central Basin Platform. The Central Basin uplift reached its peak during the late Mississippian and early Pennsylvanian time as the result of tectonic stress associated with plate collision and loading during the Ouachita - Marathon orogeny. The Central Basin uplift divided the Tobosa Basin into the deeper Delaware Basin (southeast) and shallower Midland Basin (to the east). Tectonically induced 


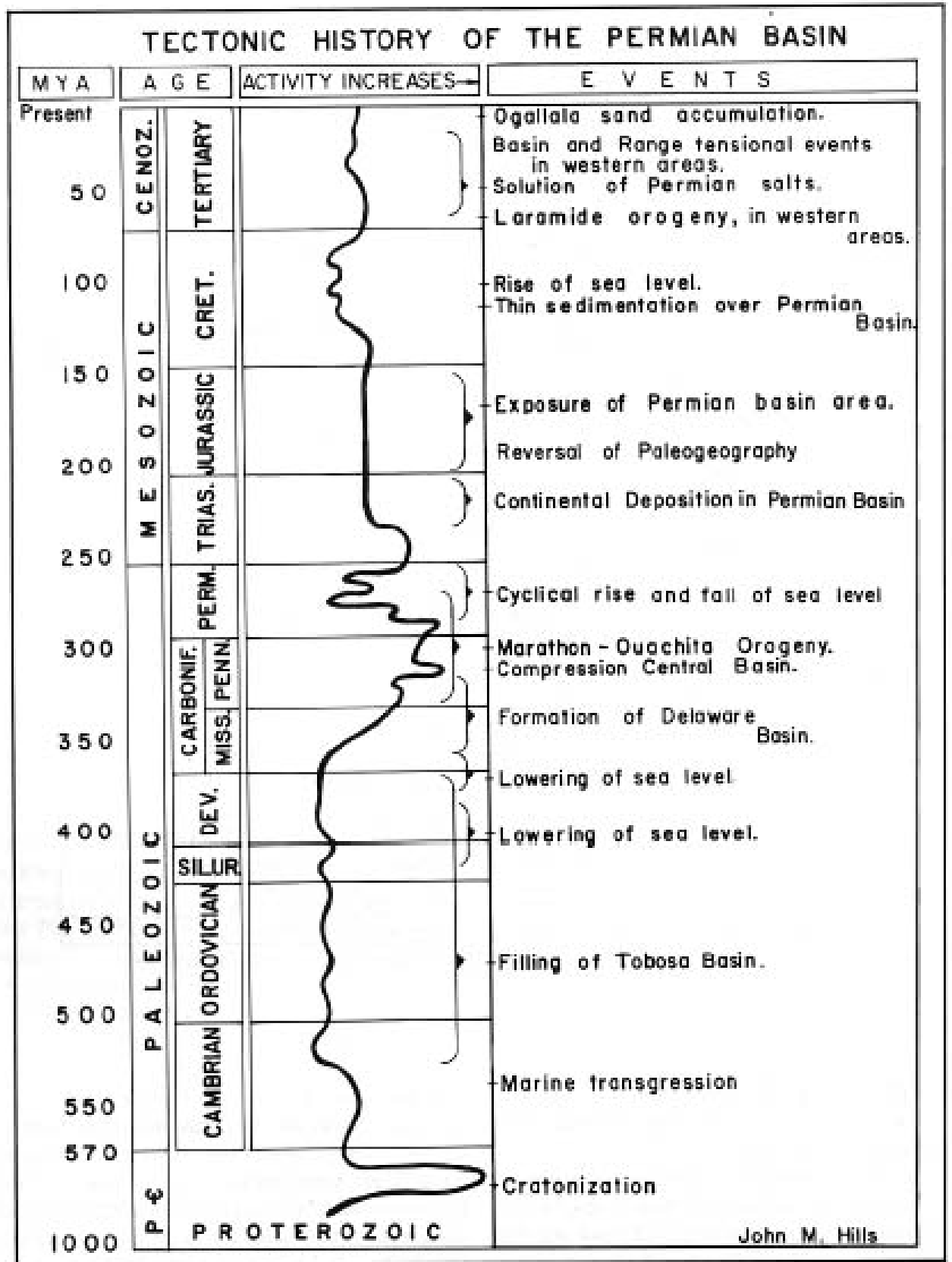

Figure 2.3: Tectonic history of the Delaware Basin and its predecessor Tobosa Basin (Taken from Hills and Galley, 1988). 
subsidence continued into the Permian Period. Erosion of the Pedernal uplift to the northwest and west and the Central Basin Uplift to the east served as the source for thick Permian age shallow water platform and deep-basin deposits (Mazzullo, 1995).

\subsection{Stratigraphy}

The stratigraphy of the Northwest Shelf of the Delaware Basin is shown in Figure 2.2. The section of interest within the study area extends from late Mississippian to middle Permian time. The description below is restricted to a discussion of the major stratigraphic units deposited during this time.

During the middle Mississippian period, deposition along the shallow shelf of the Tobosa-Delaware basin consisted mainly of shallow marine carbonates. Upper Mississippian black organic shale units of the Chesterian series overlie the middle Mississippian carbonates. The organic shale units grade into thin-bedded limestone in the northern part of the basin and across the Northwest Shelf (Hills, 1988).

The Pennsylvanian strata on the Northwest Shelf of the Delaware Basin exhibit considerable variability in distribution, lithology and thickness. The stratigraphic subdivisions of the Pennsylvanian strata are largely based on Fusulinid occurrence (Hills, 1988) leading to 5 major series. These five series, from oldest to youngest consists of the Morrow, Atoka, Strawn, Canyon and Cisco formations. According to the Meyer (1966: in Hills, 1988), the Pennsylvanian sequence along the Northwest shelf ranges in thickness from 840 to $915 \mathrm{~m}$. 
The Morrow and Atoka formations are comprised of interbedded sand, shale and thin limestone deposits whereas the Strawn, Canyon and Cisco consist primarily of cyclic sequences of carbonate and shale deposition. The Morrowan sediments have been divided into three stratigraphic units: the lower Morrow, middle Morrow and the upper Morrow. The lower Morrow is dominated by clastic sand and shale that unconformably overlie the Mississippian Barnett Shale. The middle Morrow comprises marine sandstone and shale. The uppermost unit of the Morrow series is characterized by light gray limestone with interbedded shale and sandstone of marine origin (James, 1985). The Atokan sediments are characterized by marine shale, limestone and lenses of sandstone beds. The Morrow and Atoka sediments were deposited on a broad shelf of the basin and the major sources for these clastic deposits were from the erosion of the Pedernal Uplift on the northwest and Central Basin Platform to the east of the Delaware Basin. Most of the shale, along with fine grained sandstone and limestone were deposited in a marine and shelf edge environment (Ota, 2001). The Upper Atoka is characterized by deltaic to marine facies and the lower Atoka is of fluvial origin. The environment of deposition during Morrowan time is shown in Figure 2.4.

The Strawn Formation overlies the Atoka Formation and consists mostly of limestone and thin interbedded shale. The Strawn is also one of the more prolific oil and gas producers in the region (Hills and Galley, 1988). The Cisco and Canyon formations overlie the Strawn Formation and are comprised mostly of shallow open shelf margin carbonates and shale (Hills and Galley, 1988). 


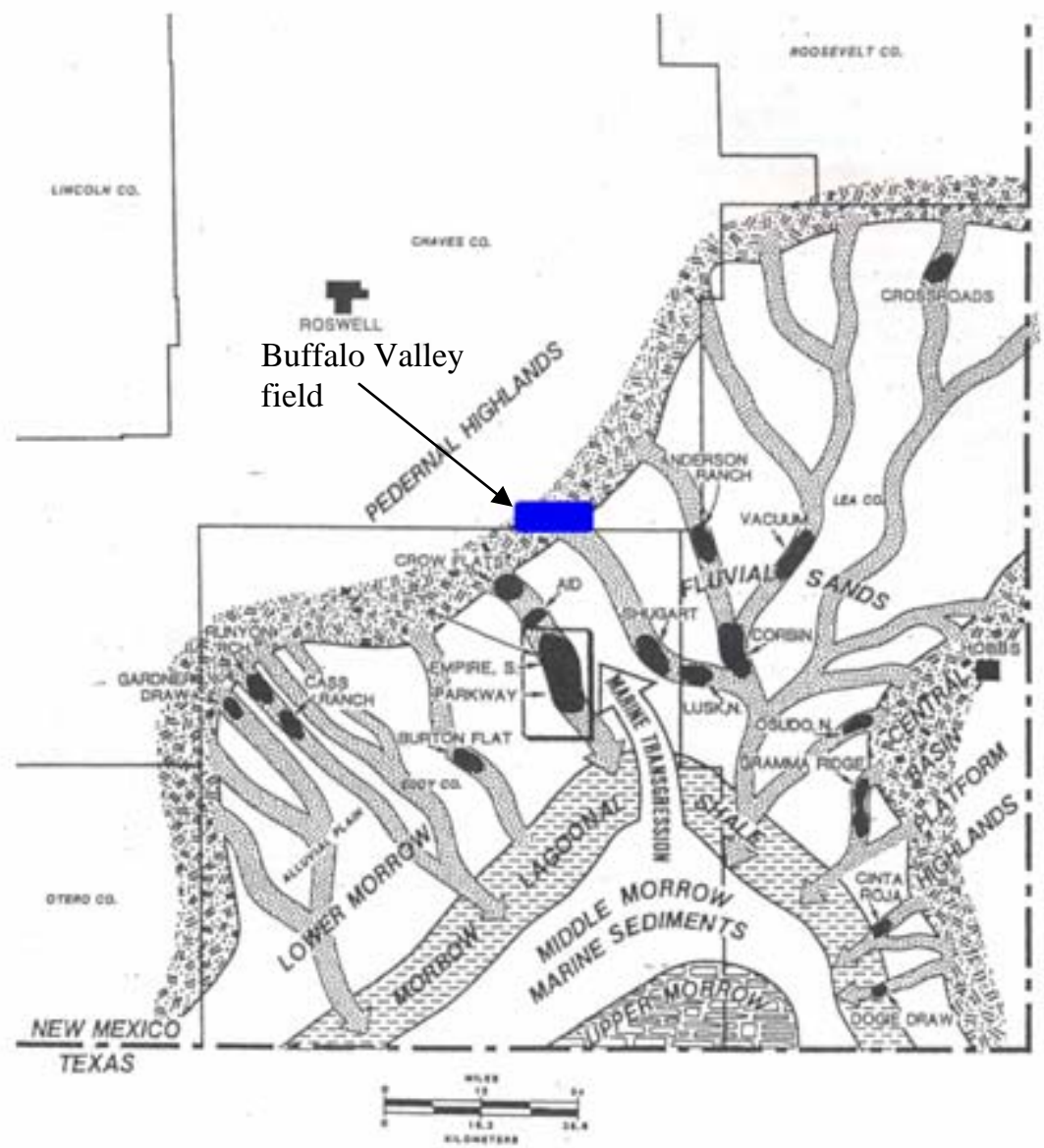

Figure 2.4: Interpreted depositional environment in the southeastern New Mexico area during the Morrowan time, taken from James (1985). 
The Permian sediments are subdivided into four series (Figure 2.2), including the Wolfcampian, Leonardian, Guadaluupian and Ochoan series (oldest to youngest). Wolfcampian sediments deposited on the Northwest Shelf consist of a cyclic sequence of limestone and interbedded shale. These are conformably overlain by the Abo Formation of the Leonardian series which consists mainly of red fluvial sandstones. The Abo is overlain by the Yeso Formation that consists of evaporite and dolomite units with interbedded sandstone. The Yeso depositional environments range from Sabkha (salt flat) and tidal flat to shelf edge carbonate bank (Mazzullo, 1982).

The upper Permian stratigraphic sequence consists of the Guadalupian and Ochoan Series. The Guadalupian appears to have been deposited during a period of rapid subsidence and in the absence of active faulting (Mazzullo, 1995). The series consists of the San Andres, Grayburg, Queen, Seven Rivers, Yates and Tansill formations (oldest to youngest), respectively. The San Andres and Grayburg formations consist of limestone, dolomite and evaporites deposited in a shallow shelf, open marine to Sabkha tidal flat environment (Hills, 1988). The Queen Formation is composed of shallow water dolomite and clastic rocks. It is characterized by a complex suite of siliciclastics, carbonates and evaporite deposits. The oil bearing sandstone reservoir along the Northwest Shelf within the Queen Formation is the Shattuck sandstone member (Haight, 2002). The seven rivers, Yates and Tansill formation includes hypersaline evaporates, redbeds and dolomites deposited in barrier-islands, shallow water lagoons or coastal Sabkha flats (Mazzullo, 1995). 
The Ochoan series of the Northwest shelf includes the Dewey Lake, Rustler and Salado formations, from oldest to youngest. The Ochoan rests unconformably on the Tansill Formation. The Ochoan deposits consist mainly of evaporites and terrigenous clastics deposited in an arid environment. Deposition occurred during sea level regression and the final infilling stage of the Delaware Basin (Hills and Galley, 1988). 


\section{CHAPTER 3}

\section{REGIONAL AND LOCAL GEOLOGY FROM WELL LOGS}

\subsection{Introduction}

This chapter discusses the regional geological characteristics of the Buffalo Valley field and surrounding area with emphasis on the Atoka-to-Chester interval. The discussion is based on well log signature and formation top information obtained from the driller's logs and scout cards. Seismic data is a critical investigative tool for reservoir characterization but such data is usually limited to the play or prospect level. Further, seismic data is also constrained by an inherent vertical resolution limit of several tens of feet to well logs which have resolution limits of only a few inches. Well log based studies also help place the local seismic interpretation into the context of the regional geology. They also provide the regional context for the local 3D seismic interpretation. In this section the interval of interest (the Atoka-to-Chester interval) is discussed in detail along with its characteristic log responses. Later in the chapter, regional and local interpretations of the geology of the area are presented. These discussions are restricted to the Middle Permian (Glorietta and Wolfcamp formations), Pennsylvanian (Cisco, Canyon, Strawn, Atoka and Morrow formations), and to the Upper Mississippian (Barnett and Chester formations) in the Buffalo Valley field.

\subsection{Well log Characteristics for the Atoka-Morrow interval}

The Morrow Sandstone is a prolific oil and gas reservoir in southern New Mexico. The lower and middle Morrow sandstones are regarded as the primary 
development and exploration play in this region (Casavant, 1999). Well completion reports and well log interpretations show that the Morrow Formation consists of limestone, sandstone and shale intervals. Influence of both progradation and aggradation can be observed in the Morrow sediments and results in considerable reservoir complexity. In general Atoka through Morrow strata were deposited in nearshore-deltaic environments.

Stratigraphically, the Morrow Formation rests unconformably on the Mississippian Barnett shale and Chester limestone; it is overlain by the Atoka Formation. In the Buffalo Valley field, there is no distinct wire line log separation between the Morrow and Atoka formations due to transitional nature of the depositional environment associated with these formations. The characteristics of this lower Pennsylvanian section in the Buffalo Valley are similar to those of the Atoka-Morrow interval described by James (1985) in the Parkway-Empire area about 20 miles to the south of the Buffalo Valley field. In the Buffalo Valley field, the thickness of the Morrow varies from approximately $70 \mathrm{ft}$ to $200 \mathrm{ft}$; its elevation varies from approximately $3000 \mathrm{ft}$ to $5000 \mathrm{ft}$ below sea level. Mazzullo (1999) described the deposition of the Morrow sediments as taking place during a period of relative tectonic stability. The underlying Upper Mississippian rocks were subjected to a prolonged period of erosion and widespread peneplanation during a drop of sea level. The Pennsylvanian Morrow sediments were then deposited in a broad southeastward sloping alluvial fan complex (Mazzullo, 1999). The major source of sedimentation was from the Pedernal uplift to the northwest; minor amounts of sediment were derived from the uplifted Central Basin Platform to the east. 
The Morrow Formation has been divided into three correlative units as illustrated in the type log (Figure 3.1). The lower Morrow consists of fluvial clastics with interbedded shale that rest upon the Mississippian Barnett shale. The lower Morrow sediments were deposited in a fluvial-deltaic system of channels, point bars and stream mouth bars (James, 1985). The Gamma ray logs (Figure 3.1) suggest presence of upward coarsening cycles followed by fining upward cycles from the base to top of the lower Morrow. The log cycles are interpreted to result from cycles of progradation and transgression in a deltaic to near shore environment (Sanchez, 2004). The oil and gas production in the Buffalo Valley field is primarily from the lower Morrow. Oil and gas is produced from stratigraphic traps in fluvial sands associated with variations in depositional patterns and cementation (James, 1985).

A thin layer of shale separates the middle Morrow from the underlying Lower Morrow. The overall log signature at the middle Morrow shows high variability with both fining upward and coarsening upward cycles. The lower part of the middle Morrow has a “funnel shaped” Gamma ray log pattern which is interpreted as a coarsening upward sequence. The coarsening upward sequence is followed by an upward bell shaped sequence indicative of an upward fining trend. The upward coarsening and fining trends in the middle Morrow are interpreted to be deltaic sands reworked by the marine transgression. Casavant (1999) suggest that these sands were reworked in lower deltaic and deltaic plain environments by wave dominated processes, and then deposited as beach or bar sands during a rapid marine incursion. Similar to Casavant, James (1985) interpreted the middle Morrow sediments to have been deposited as beach and shore bar sandstone in the Parkway- Empire Field, 20 miles south of the Buffalo Valley field. 


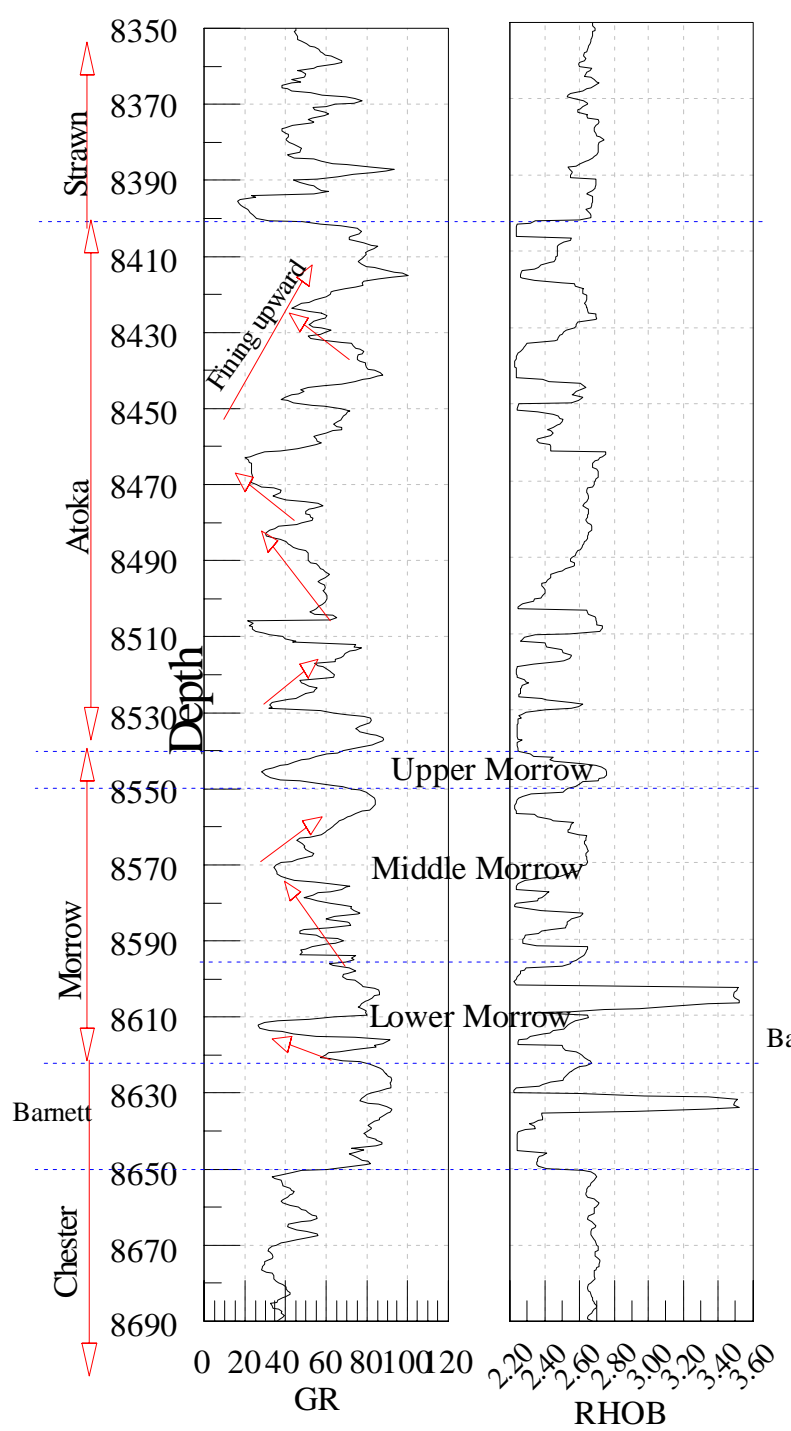

a)

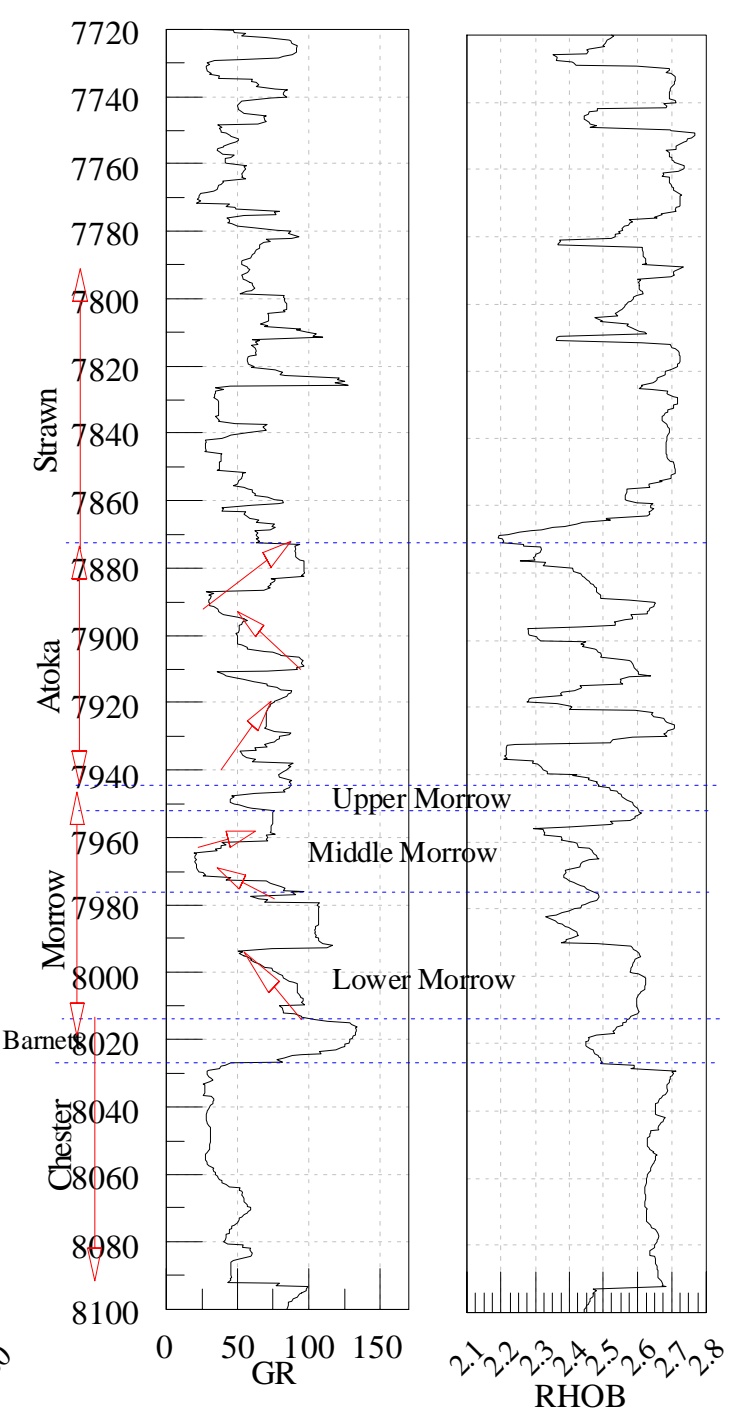

b)

Figure 3.1: Typical Gamma ray (GR) and Density (RHOB) responses of the AtokaMorrow interval. The variability in the log signatures clearly portrays the heterogeneity of the area, a) well API \# 3000560481 b) well API \# 3000560321 
The upper Morrow interval is dominated by carbonates. The gamma ray response suggests varying shale content. The upper Morrow has average density of $2.71 \mathrm{gm} / \mathrm{cc}$ (Figure 3.1). The upper Morrow consists of marine limestone and basinal shales with minor amounts of sandstones. The carbonate units have been interpreted to onlap the thick, clastic fluvial-deltaic sequence of reservoir sands (Casavant, 1999) in the White City Penn Gas Pool, south of the Buffalo Valley field in Eddy County. The separation between the overlying Atoka Formation and upper Morrow interval is considered to be a shale unit, however, a distinct separation between the Atoka and the upper Morrow in the Buffalo Valley area is not observed. The transition is similar to that in the ParkwayEmpire Field where a distinct Atoka-Morrow contact is also not observed (James, 1985).

The Atoka Formation lies between the Strawn and Morrow formations. Ota (2001) and Casavant (1999) noted that the basal contact of the Atoka is an erosional unconformity. The major lithological units of the Atoka Formation consist of limestone with interbedded shale and sandstone. The wireline log signature (Figure 3.1) shows two distinct events: an upward fining and upward coarsening sequence. Ota (2001) notes that the lower Atoka is marked by a fining upward sequence characteristic of a fluvial environment. In the Buffalo Valley area, the lower Atoka consists of sandstone and shale and shows a fining upward cycle in the gamma ray log. The upward fining sequence is interpreted to represent of a shift from deltaic to marine environments. James (1985) described the Atoka sands as being deposited in a shallow marine environment as prograding beach and bar sands.

The gamma ray log signature exhibits a "bell shaped" (upward low to high) response indicating fining upward sequence in the upper part of the Atoka Formation. 
The fining upward sequence is interpreted to include smaller coarsening upward parasequence. The parasequence resulted from sands formed in deltaic environments later terminated by marine encroachment associated with sea level transgression (Sanchez, 2004); marine shale was deposited as the uppermost lithological unit.

The middle and upper Pennsylvanian Strawn, Cisco, and Canyon formations begin with a deep marine shale base and grade into deeper marine carbonates. The Strawn Formation is associated with a thick carbonate sequence of deep marine origin. The overlying upper Pennsylvanian Canyon and Cisco formations represent cycles of marine transgression and regression with carbonates at the top.

\subsection{Structure in terms of the Regional Setting}

Regional subsea structure maps of the Chester and Atoka formations were constructed to help place the local structures of the Buffalo Valley field into the regional context of structure along the Northwest Shelf of the Delaware Basin in this area. The structure maps are based on the well logs and formation top depths obtained from driller's log. A total of 20 townships were used in the regional study, including 4 townships from Chavez County and 16 from Eddy County (Figure 3.2).

The top of the Mississippian Chester Formation is an easily identified and persistent contact in the area and provides a reliable view of regional structure in the area. The top of the Chester is a limestone that is easily distinguished from the overlying Barnett shale on the well logs (Figure 3.1). Limestone at the top of the Chester Formation is characterized by low gamma ray and high density. The contact with the Barnett occurs as a sharp break from low to high gamma ray and high to low density in the Barnett Shale. 
Structure on the top of the Chester Formation (Figure 3.3) dips uniformly to the southeast with a strike of about $\mathrm{N} 30^{\circ} \mathrm{E}$. The structural high is located towards the northwest corner of the map with subsea elevation of $-3500 \mathrm{ft}$ and a structural low is located in the southeast corner of the map with maximum subsea elevation of $-8500 \mathrm{ft}$. The average dip across the shelf in this area is approximately $16^{\circ} \mathrm{SE}$. Steepening of the gradient along a trend passing through the Buffalo Valley field suggests that the field lies over the hinge area separating the Northwest shelf from the Delaware Basin. The northeast structural trend of the Chester Formation is similar to the northeast structural trend of the Precambrian basement described by Hills (1970) (Figure 3.4). This suggests basement control over the overlying Chester units.

The regional structure on the top of the Atoka Formation (Figure 3.5) is similar to that observed on the underlying Chester Formation. The structure on the Atoka is associated with a pronounced NE-SW strike; regional dip is to the southeast toward the interior of the Delaware Basin. The subsea elevation to the top of the Atoka ranges from $-3600 \mathrm{ft}$ (relative to sea level) on the shelf area to $-7500 \mathrm{ft}$ toward the interior of the Delaware Basin. The regional strike is comparable to the paleodepositional northeastsouthwest trend of the Atoka Formation described by James (1984). The regional northeast structural trend is also similar to the structural trend of the Precambrian basement described by Hills (1970). 


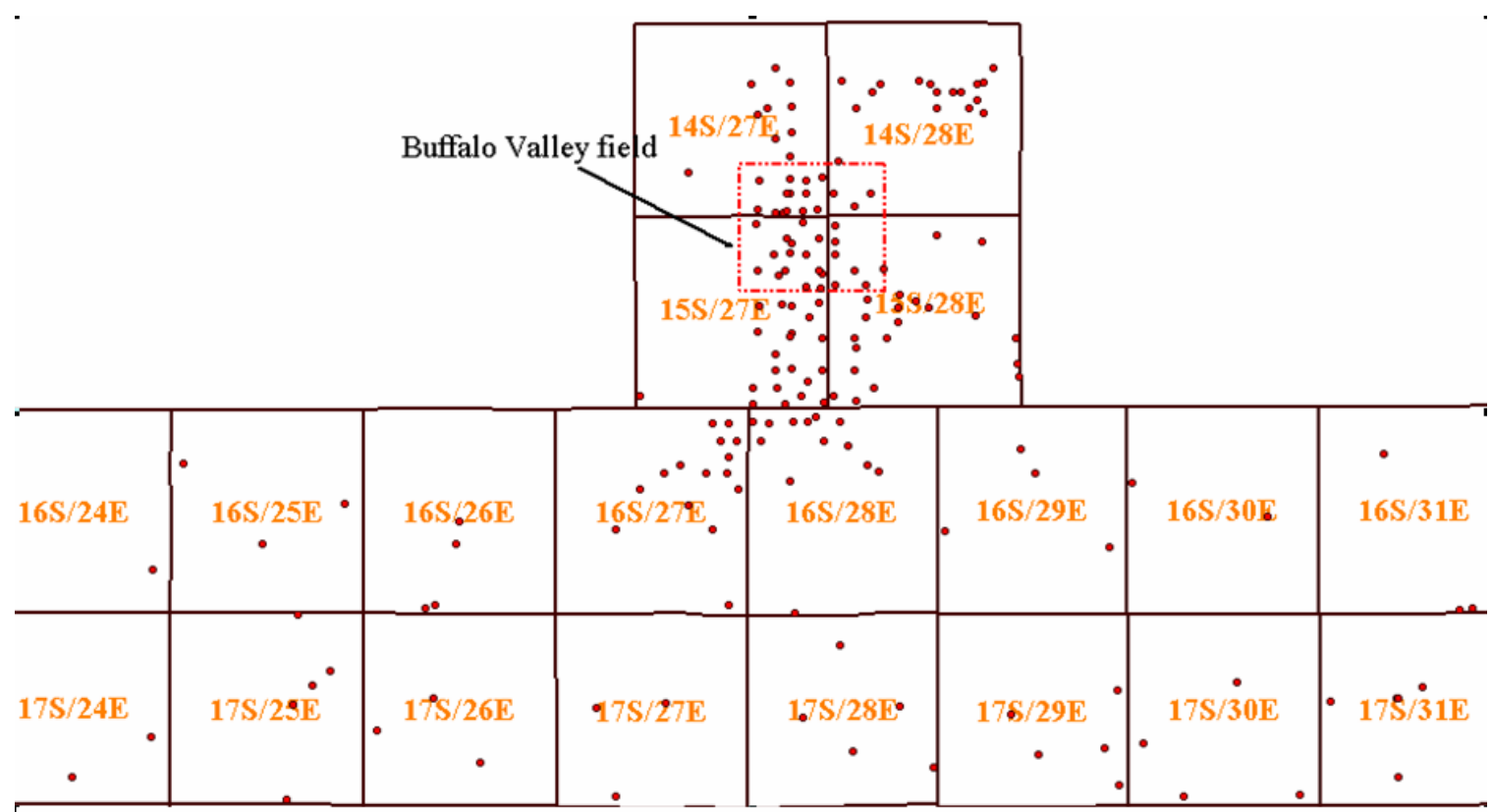

Figure 3.2: Townships with Well locations used in the regional study.

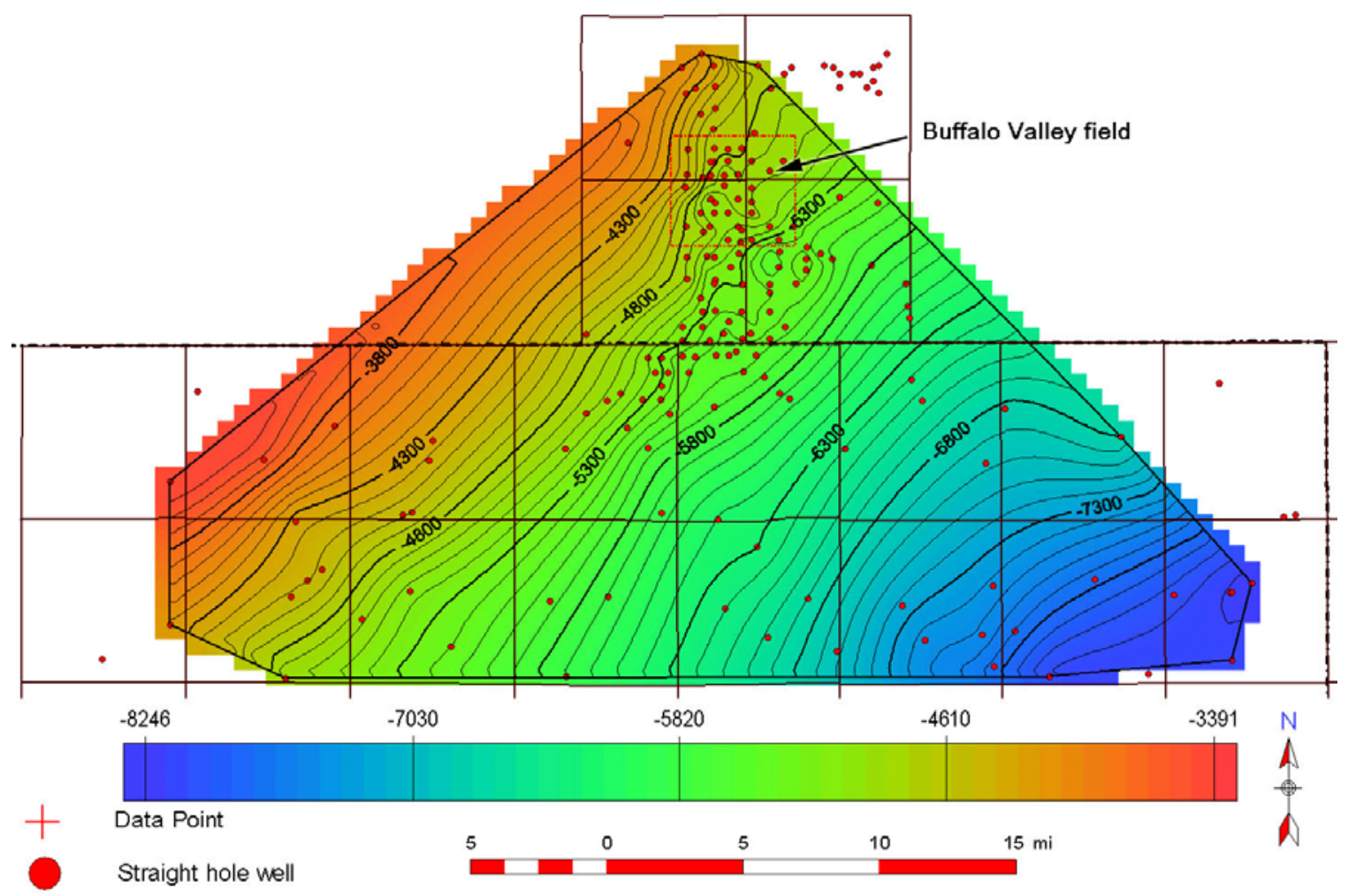

Figure 3.3: Subsea structure map on top of the Chester Formation. Contour interval, 100 $\mathrm{ft}$. 


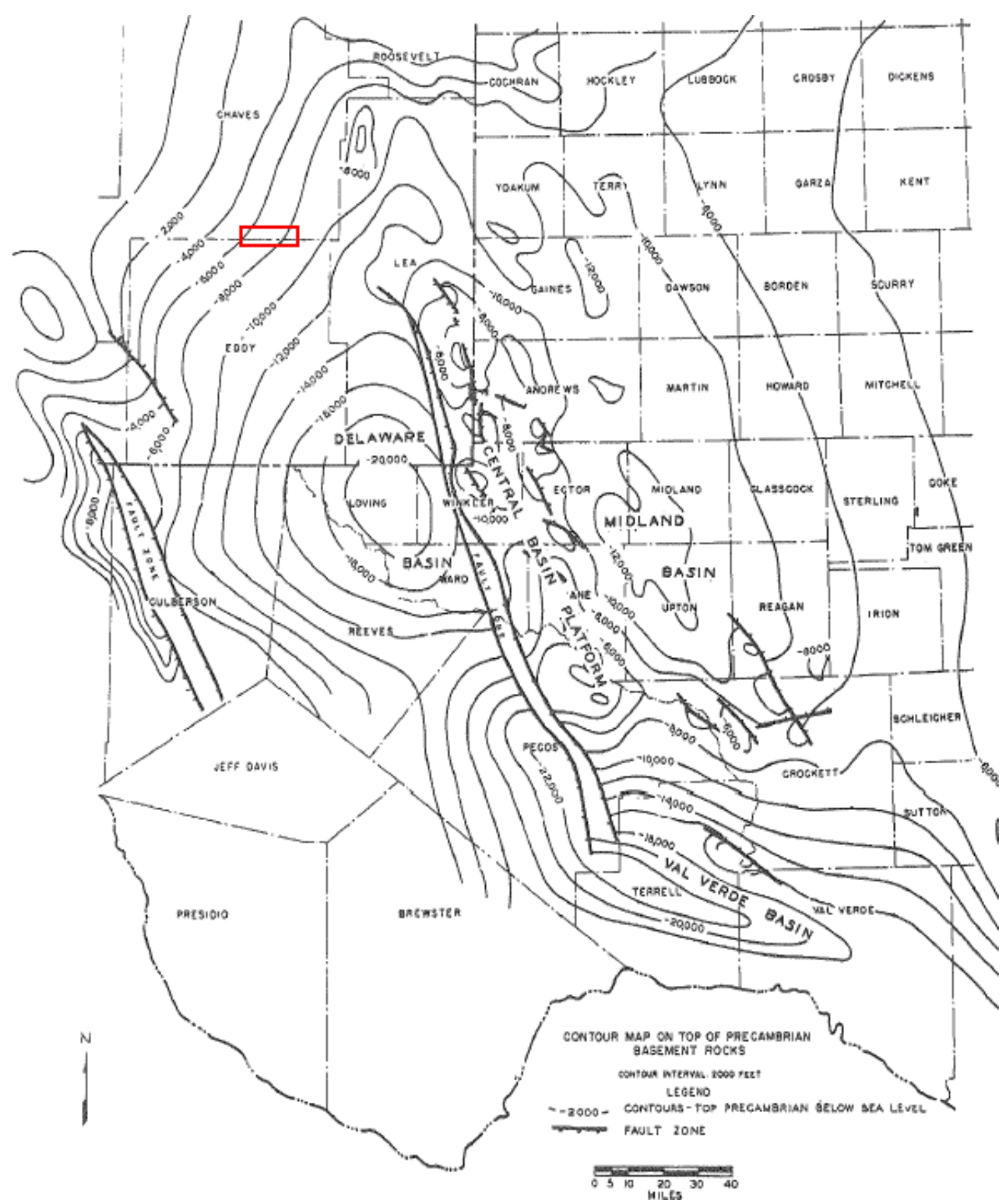

Figure 3.4: Precambrian basement configuration of the New Mexico-West Texas region. The study area on the Northwest Shelf is highlighted by red rectangle, (Modified from Hills, 1970). 


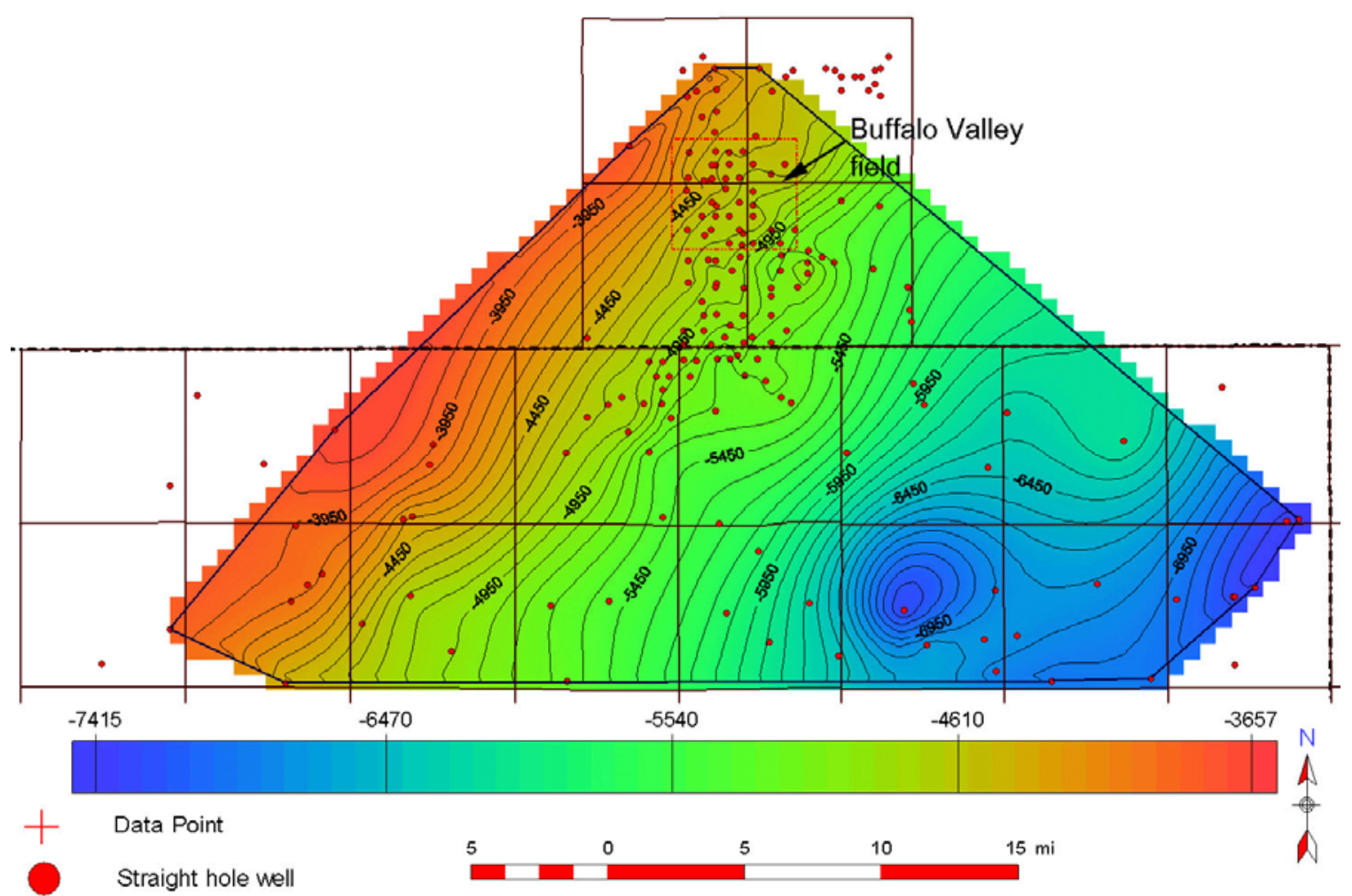

Figure 3.5: Subsea structure on the top of the Atoka Formation. Contour interval, 500ft. 
An isopach map of the Atoka to Chester interval was constructed to illustrate the influence of differential subsidence during the deposition of these intervals. The Isopach map (Figure 3.6) reveals thickening to southeast. The thickness increases from about 100 $\mathrm{ft}$ in the northwest to $1150 \mathrm{ft}$ towards the interior of the Delaware Basin to the southeast. Isopach trends are NE-SW and parallel the ancient depositional shoreline of the AtokaMorrow interval. Thickening into the Delaware Basin also coincides with the pre-existing NE-SW Proterozoic line of weakness described by Hills (1970). The steepened NE-SW gradient that crosses the area to the northwest across the area may be evidence for a deeper basement fault beneath the area.

\subsection{Local Structure within the Buffalo Valley field}

This section presents a brief description of the structural characteristics of the Buffalo Valley field within the vicinity of the 3D seismic survey. The discussion is restricted to the presentation of the structural maps of the Permian-Glorietta and Wolfcamp interval, Pennsylvanian Cisco and Morrow interval, and the Mississippian Barnett shale and Chester Formation.

\subsubsection{Chester Formation (Upper Mississippian interval)}

As explained in Chapter 2, the Chester Formation consists of a carbonate interval beneath the Barnett Shale. It is also assumed that the top of the Chester represents a conformable but abrupt transition from shallow to deep water depositional environments. This sharp limestone to shale boundary provided an easily identifiable structural reference horizon. 


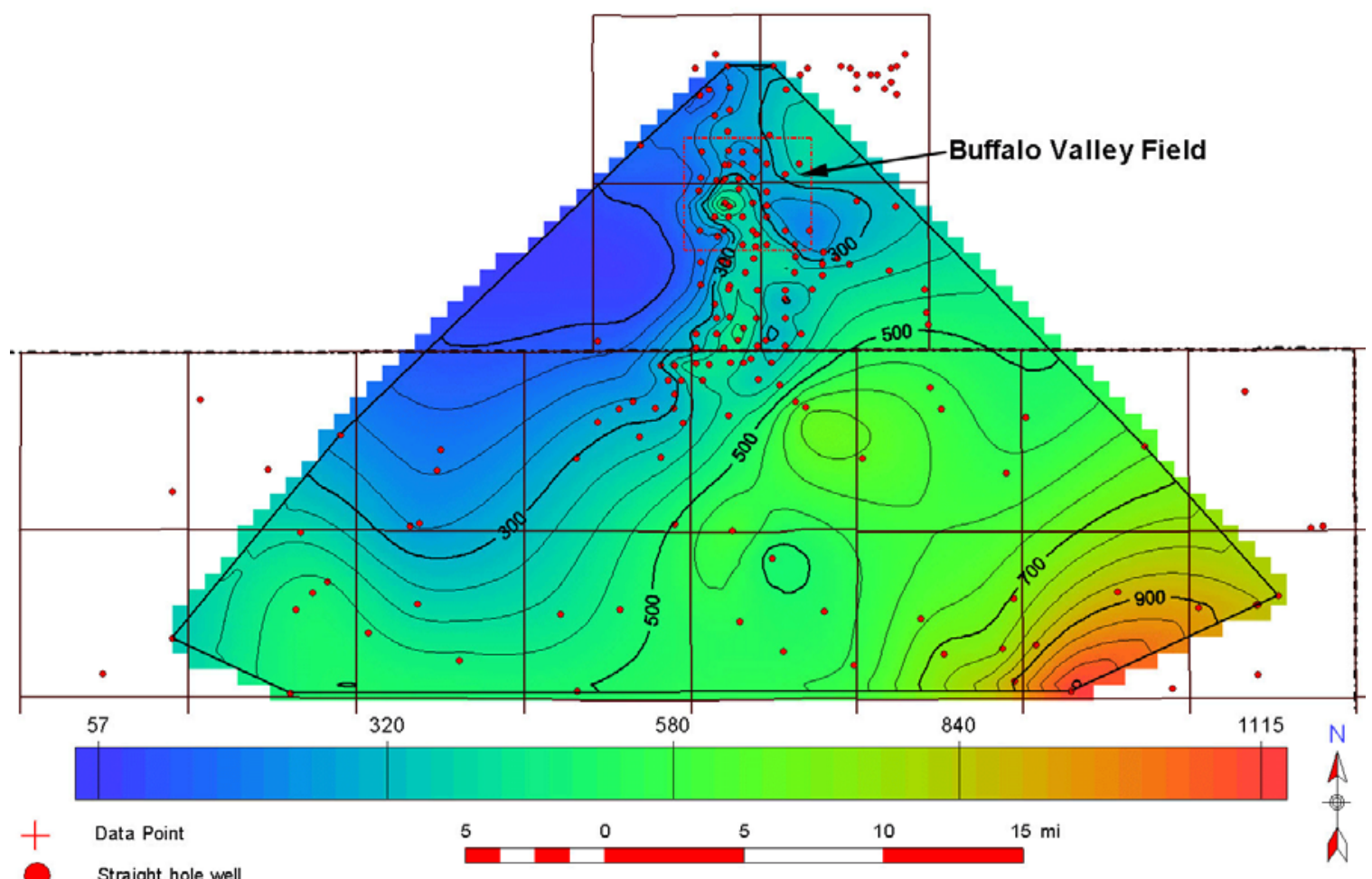

Figure 3.6: Isopach of the Atoka-Morrow interval. Contour interval, $50 \mathrm{ft}$. (Top of the Mississippian Chester Formation to top of the Atoka Formation).

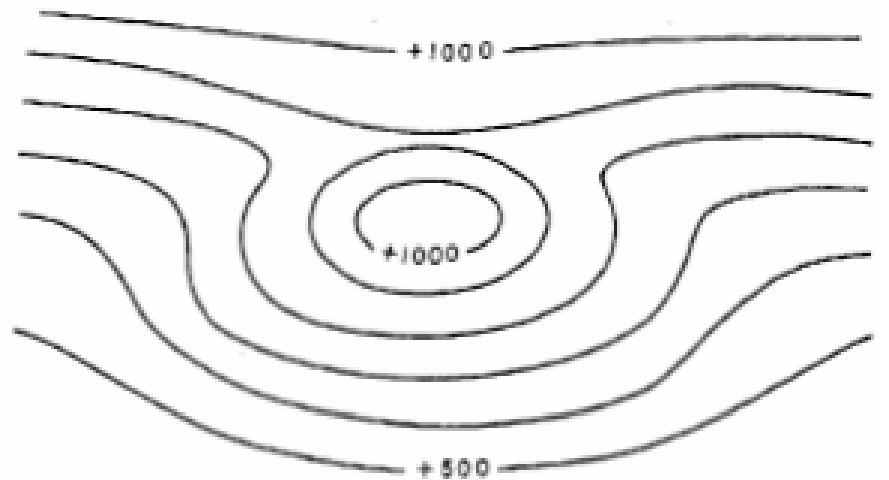

Figure 3.7: Seminole type anticline on the Northwest Shelf described by Galley (1968). 
Subsea elevation to the top of the Chester ranges from $3900 \mathrm{ft}$ to $5725 \mathrm{ft}$ (Figure 3.8). The structural high is located to the northwest; the structural low lies southeast of the seismic survey area. A low relief anticline cuts NW to SE through the area parallel to a low that extends into the center of the area from the southeast and then bends to the north. These gentle folds show some similarity to the Seminole fold (Figure 3.7) described by Galley (1968) on the Northwest Shelf area. He interpreted that these folds resulted from mild lateral compression and differential subsidence into the Delaware Basin area.

Areas of localized steepening in the structure are interpreted as potential faults (Figure 3.8). The locations of these steepened zones are enhanced in the residual map. The regional trend was calculated using a "Minimum Curvature" gridding algorithm available in the GeoAtlas module of GeoGraphix. This algorithm initially calculates the gross average value of the data and identifies the minimum number of nodes needed to represent the regional trend of the data followed by successive iteration that calculates additional grid notes to incorporate influence of local features (GeoAtlas help file, version 8.5). The residual map was obtained after subtracting the second derivative of the structure from the regional trend map. The regional and residual structural trends are illustrated in the figures 3.9 and 3.10, respectively. The residual map revealed the presence of a relative structural low that trends roughly north-to-south through the survey area (Figure 3.10).

The two maps (figures 3.8 and 3.11) show close correlation. The plunging anticline and syncline observed in Figure (3.11) are delineated in more detail in the map generated for this study (Figure 3.8). The additional detail revealed in this study is 


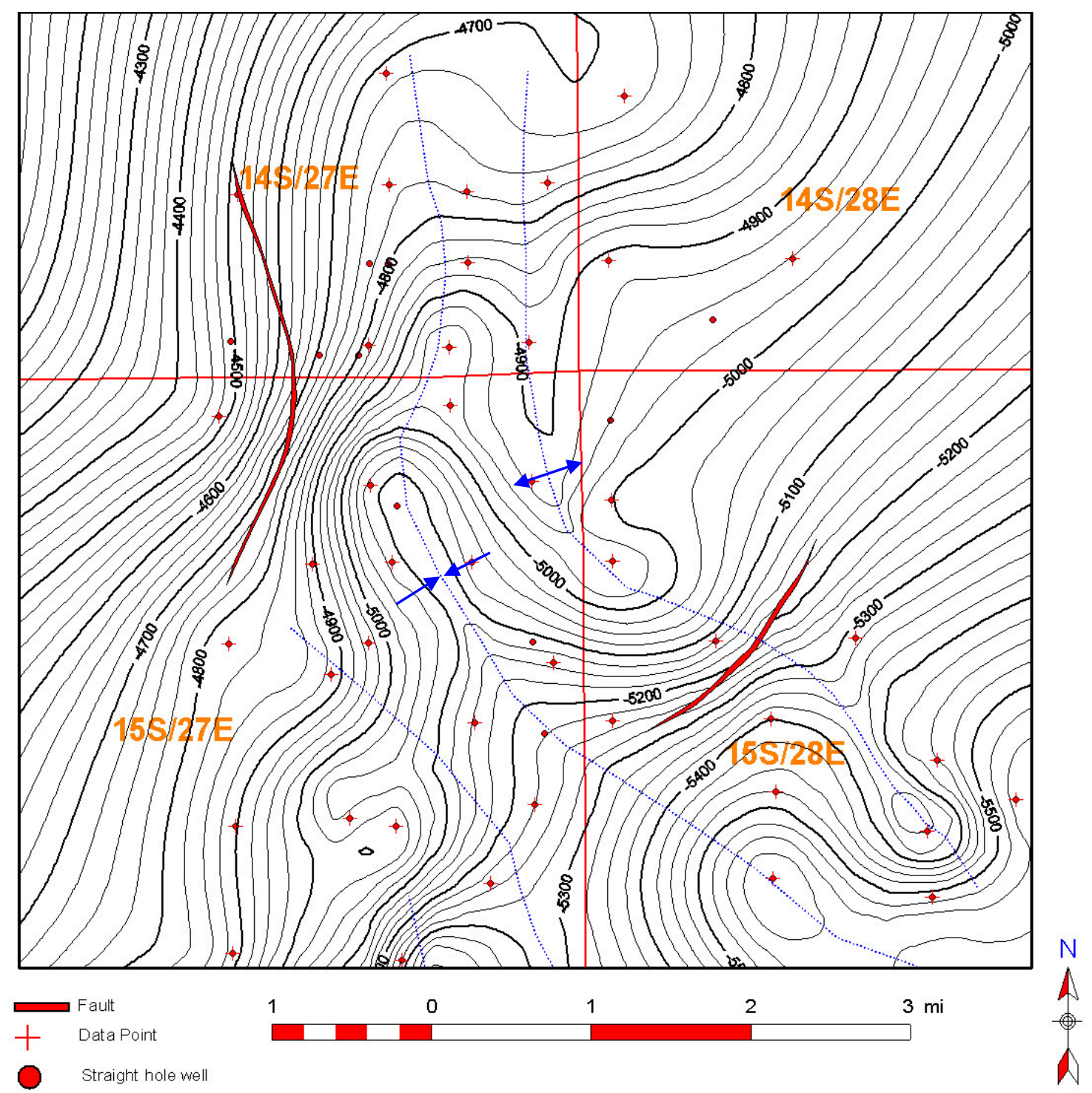

Fold Axis

Figure 3.8: Subsea Structure Map on the top of the Chester Formation. Contour interval, $25 \mathrm{ft}$. 


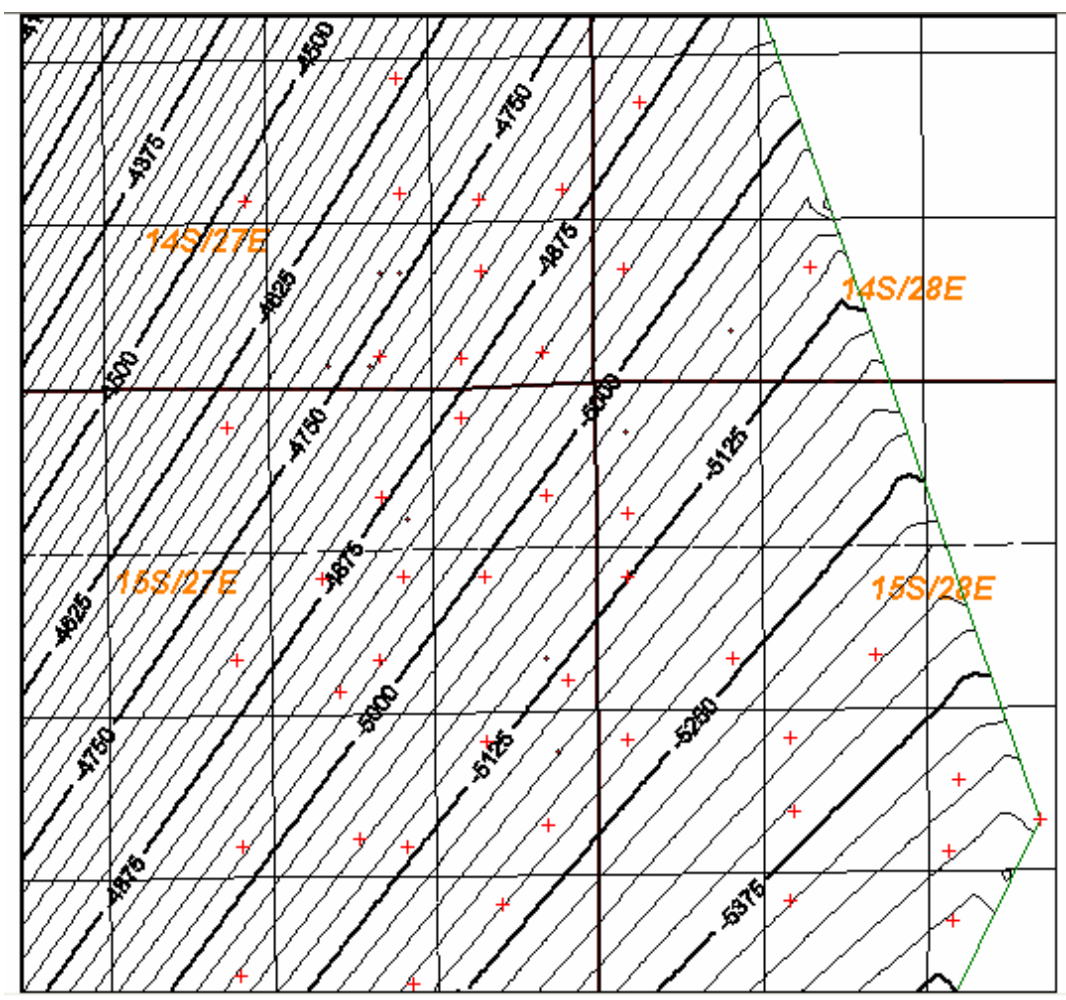

Figure3.9: $2^{\text {nd }}$ order Structural trend map of the Chester Formation. Contour interval, 25 $\mathrm{ft}$.

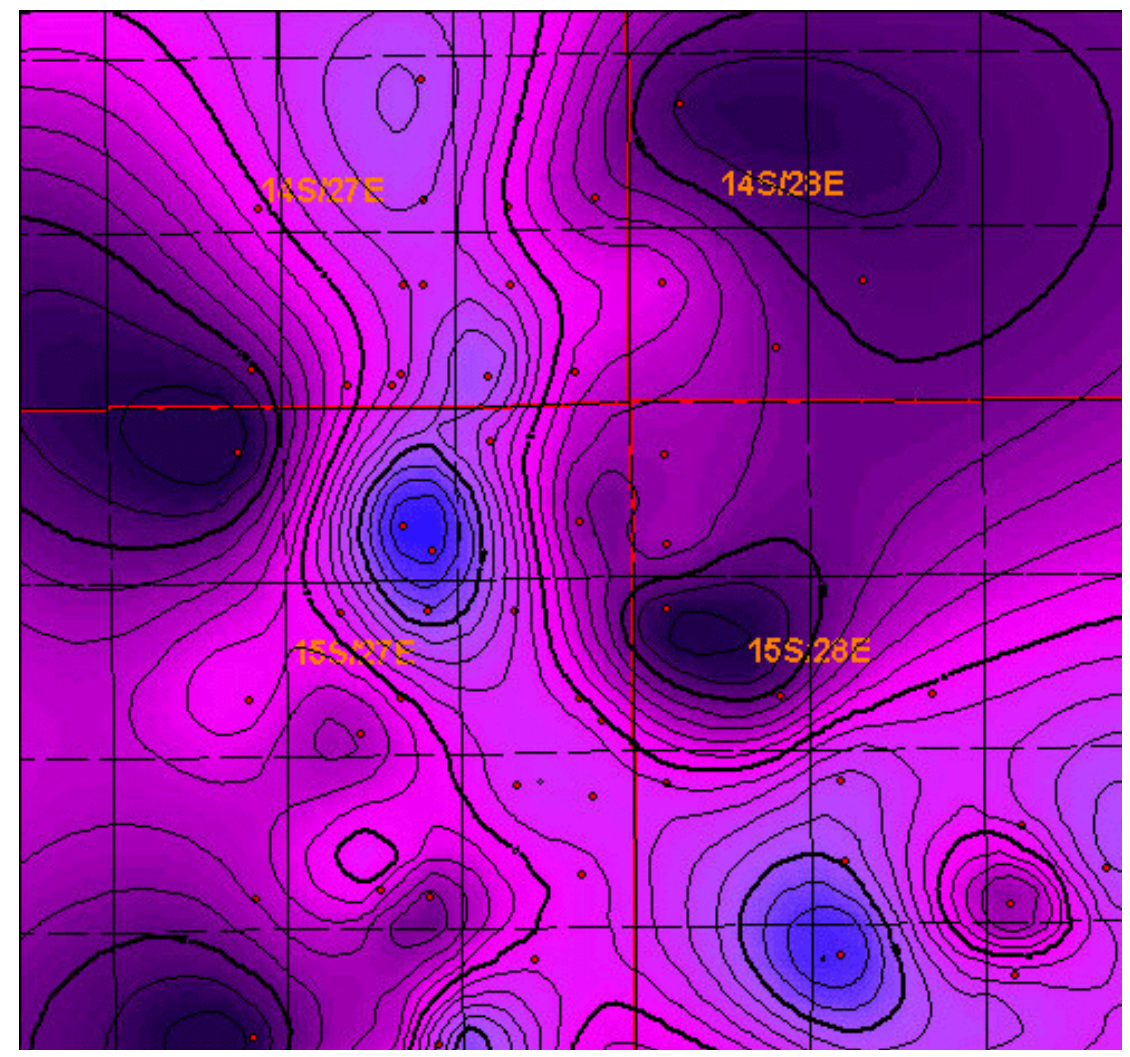

Figure 3.10: Chester structure $2^{\text {nd }}$ order residual map. Contour interval, $25 \mathrm{ft}$. 
likely due to better well control. The number of wells used in this study is greater than the number of wells used to compile the RGS map. Structural cross-sections in strike and dip direction are illustrated in figures 3.12 and 3.13. The location of these cross-sections is shown in the Figure 3.14. These cross-sections clearly reveal structural control during the deposition of the Pennsylvanian units. The strata thicken towards the south and east ends of the cross-sections along the margin of the Delaware Basin. 


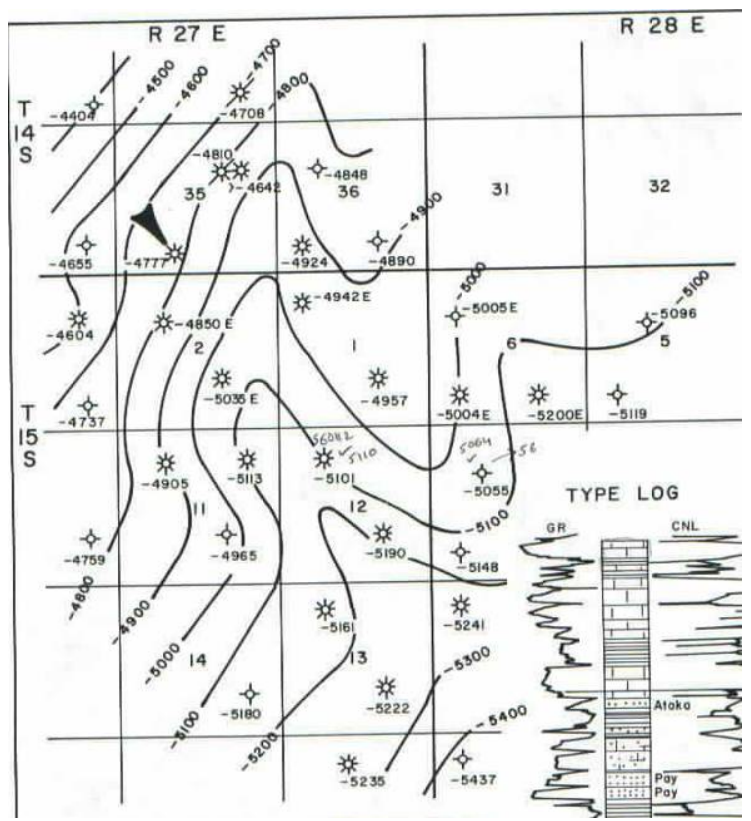

Figure 3.11: Structure on top of the Chester Formation, Roswell Geological Society Volume (1993).

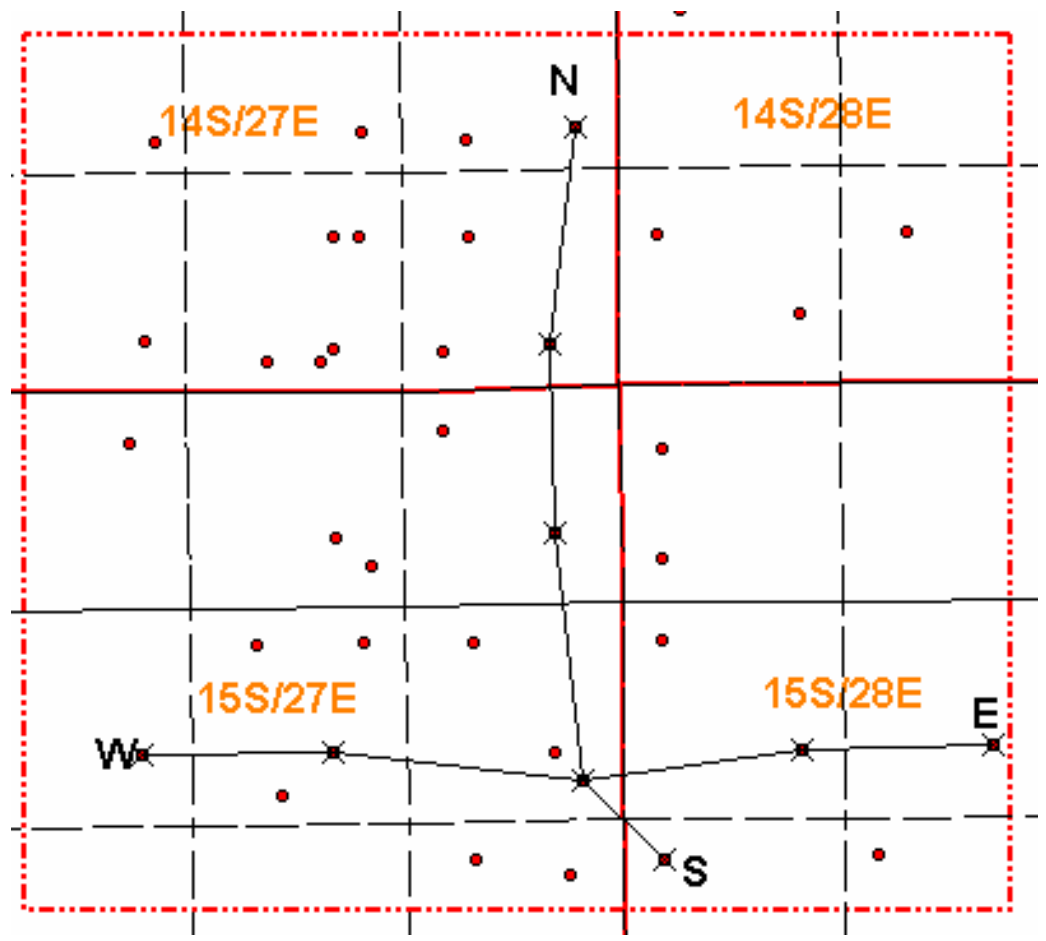

Figure 3.12: Lines showing the cross-section location within the seismic survey area. N-S and E-W represent north-south and east-west cross sections respectively. 


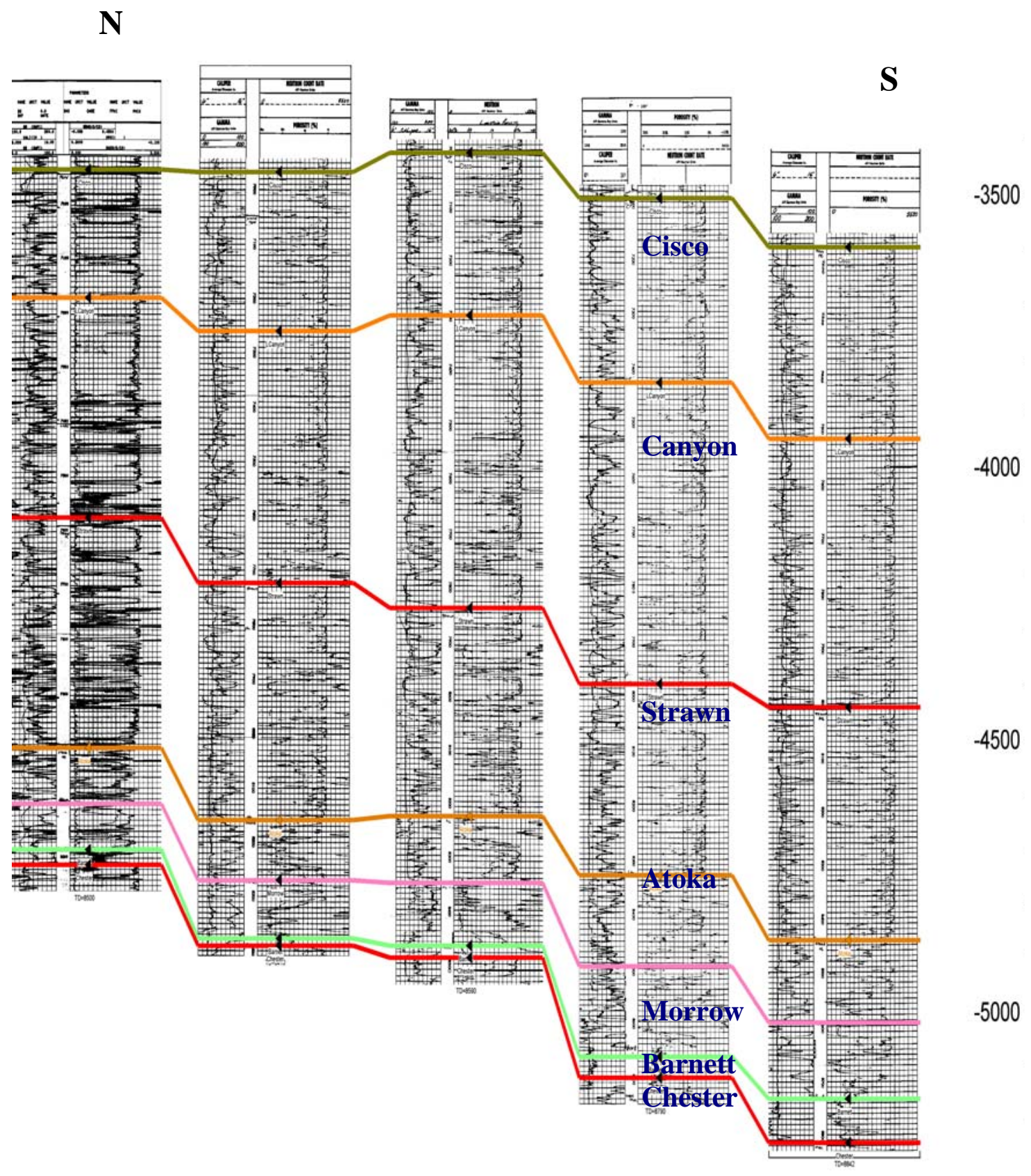

Figure 3.13: Structural Cross -section roughly along the strike (N-S line in Figure 3.12). Vertical scale to right is subsea elevation in $\mathrm{ft}$. 


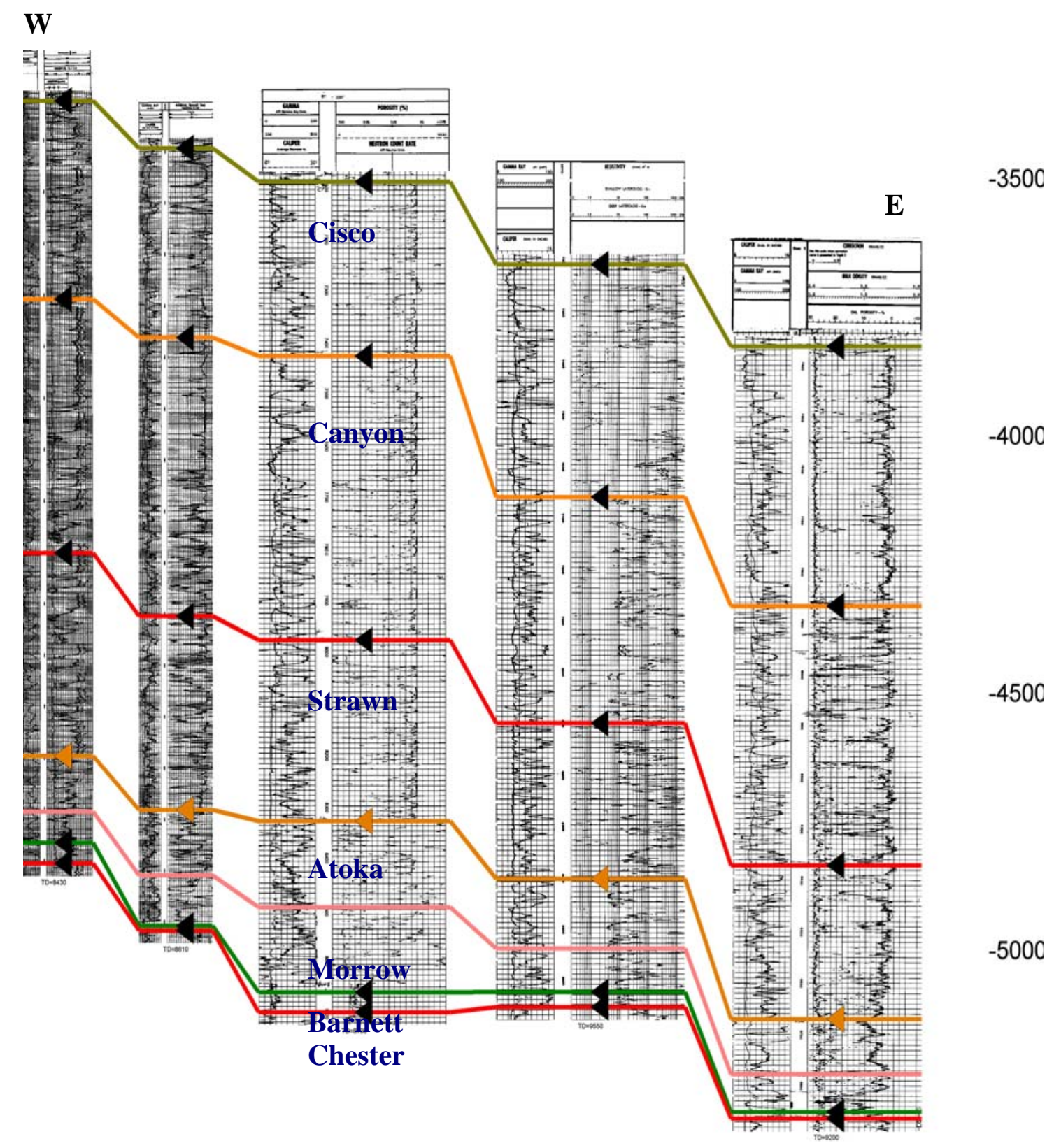

Figure 3.14: Structural Cross -section roughly along the dip (W-E line in Figure 3.12). Vertical scale to right is subsea elevation in $\mathrm{ft}$. 


\subsubsection{Atoka Formation}

The structure on top of the Atoka formation (Figure 3.15) shows some similarity to that of the Chester. A structural ridge or anticlinal nose juts northwest to southeast orthogonal to the regional northeast trend of the shelf. This ridge extends through section 1 of township 15S/27E and section 7 of $15 \mathrm{~S} / 28$. Structural relief across this ridge is roughly 50 to 75 feet. The Atoka has a strike of roughly $N 30^{\circ} \mathrm{E}$ and an approximate dip of $15^{\circ} \mathrm{SE}$. Faults interpreted on the structure contour map of the Chester are also interpreted on the structure contour map of the Atoka in areas of steepened structural gradient (Figure 3.15). The second order residual map reveals a northeast-southwest trending structural high running through the center of the area (Figure 3.16).

The isopach map (Figure 3.17) of the Atoka-Morrow interval shows a zone of thickening that extends roughly northwest to southeast through the area. The thickness is highly variable and ranges from approximately $180 \mathrm{ft}$ to $500 \mathrm{ft}$. The zone of thickening strikes at high angle to the northeast-southwest trend of the paleo-shoreline during the deposition of Atoka and Morrow formations described by James (1984). The steepened thickness gradient occurring to the northwest along the thickened zone may be associated with syndepositional growth across the fault interpreted in that area (Figure 3.15). 


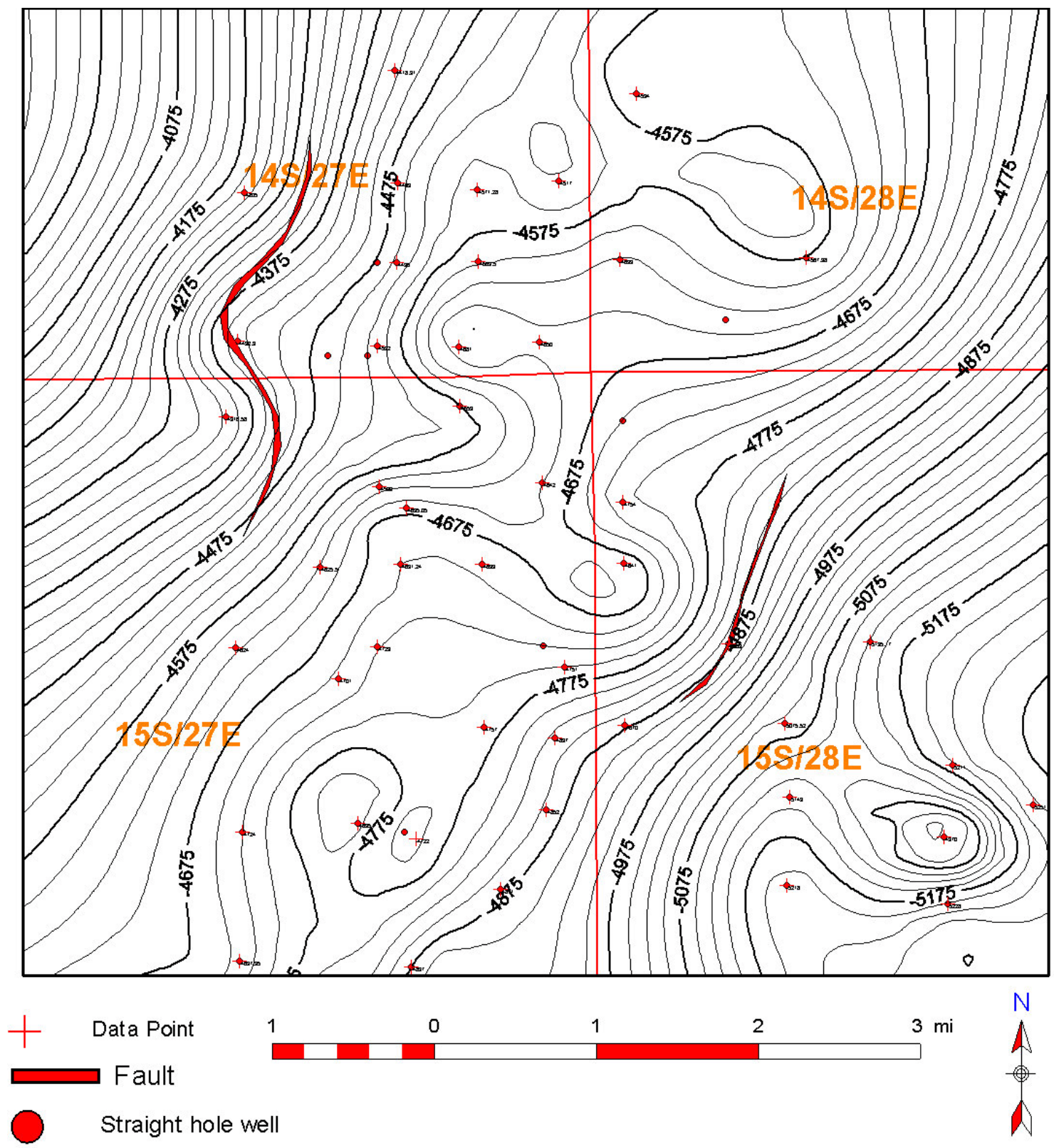

Figure 3.15 : Subsea Structure on the top of the Atoka Formation. Contour interval, $25 \mathrm{ft}$. 

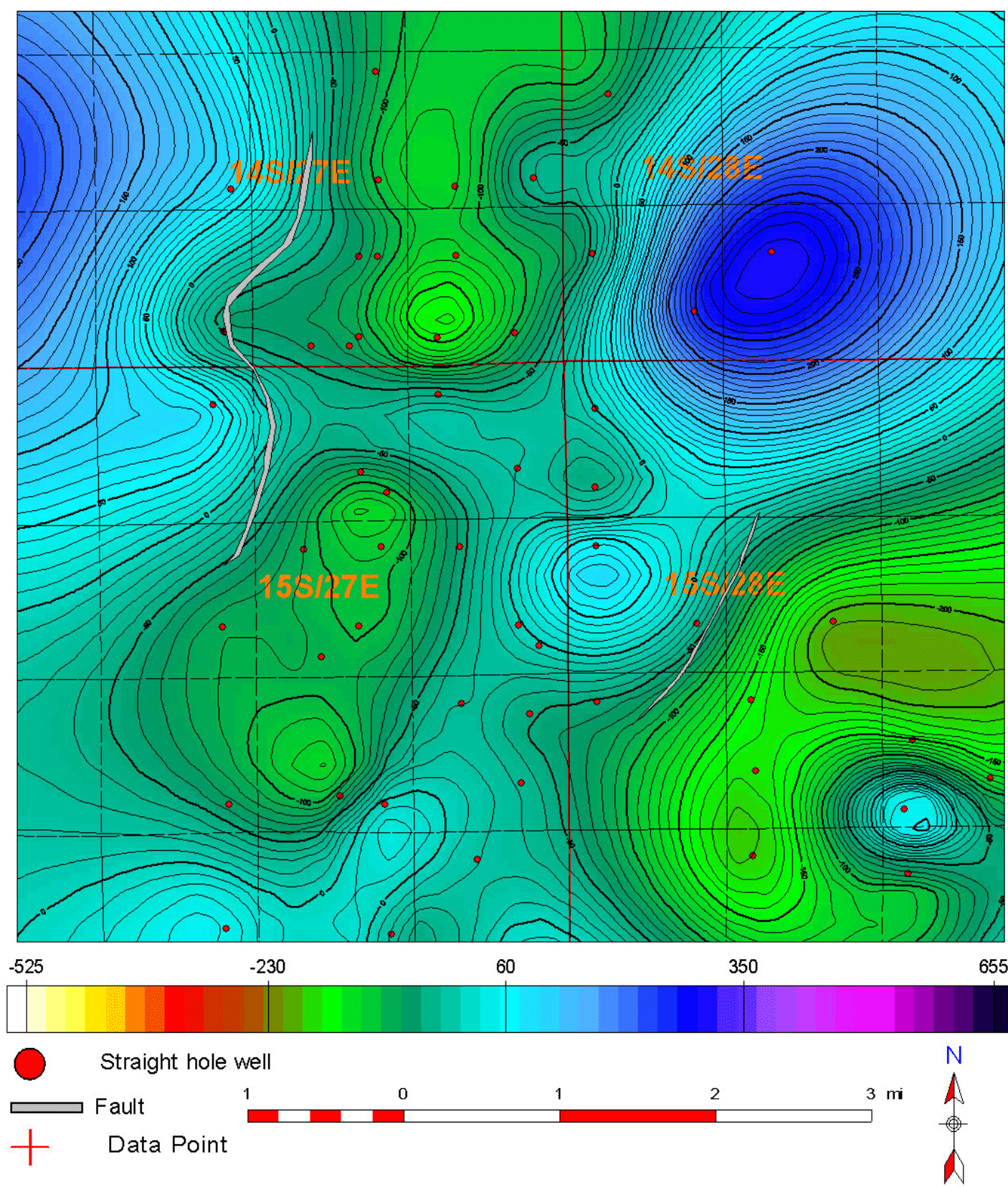

Figure 3.16: Second order residual structure on top of the Atoka. Contour interval, $25 \mathrm{ft}$. 


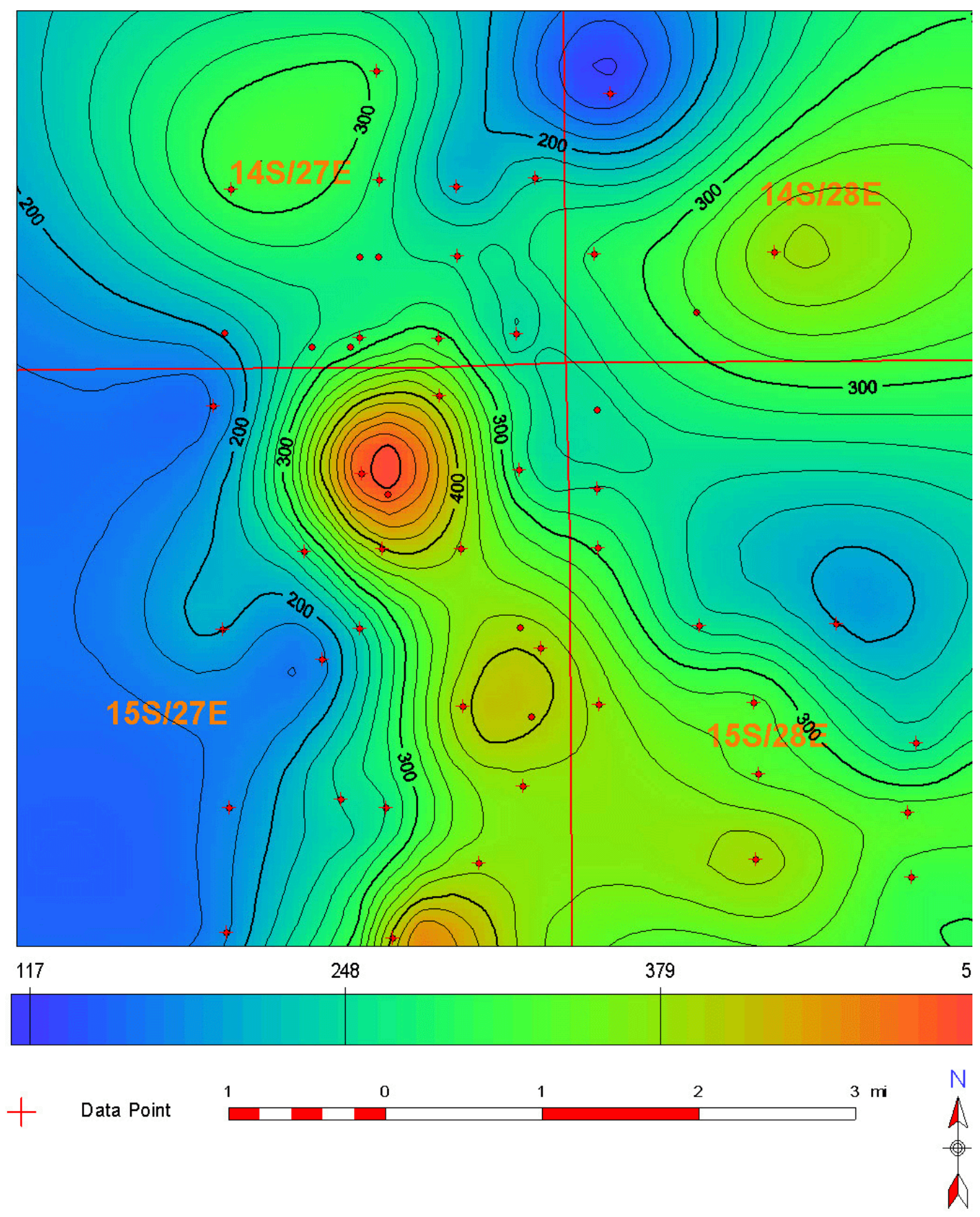

Figure 3.17: Isopach of the Atoka-Morrow interval. Top of Atoka to the top of the Chester. Contour interval, $20 \mathrm{ft}$. 


\subsubsection{Strawn Formation}

The Pennsylvanian Strawn Formation overlies the Atoka Formation. The Strawn has a strike and dip similar to that of the underlying Atoka and Chester formations. Subsea elevations range from a minimum of 4075 feet to the northwest to a maximum of $4850 \mathrm{ft}$ to the southeast. An elevated structural nose extends to the southeast near the center of the area (Figure 3.18). The structure coincides with a similar structure observed in the undulating Atoka and Chester formations. The synclinal trough located southwest of this nose is well developed only in the Chester Formation structure (Figure 3.8).

Isopach map of the Strawn Formation shows considerable variability in thickness (Figure 3.19). The thickness ranges from a minimum of $250 \mathrm{ft}$ to a maximum of $450 \mathrm{ft}$. A zone of relative thinning crosses the area from northwest to southeast through the center of the area and coincides roughly with the alignment of noses observed in the Atoka structure (Figure 3.15). The thickened zone observed in the Atoka-Morrow isopach does not appear in the Strawn. The changes in thickness suggest minor syndepositional movement of deeper structure during the deposition of the Strawn. Thinning of the Strawn to the southeast coincides with a structural low in the Strawn. This suggests that local uplift of a relatively small structural block occurred during deposition. 

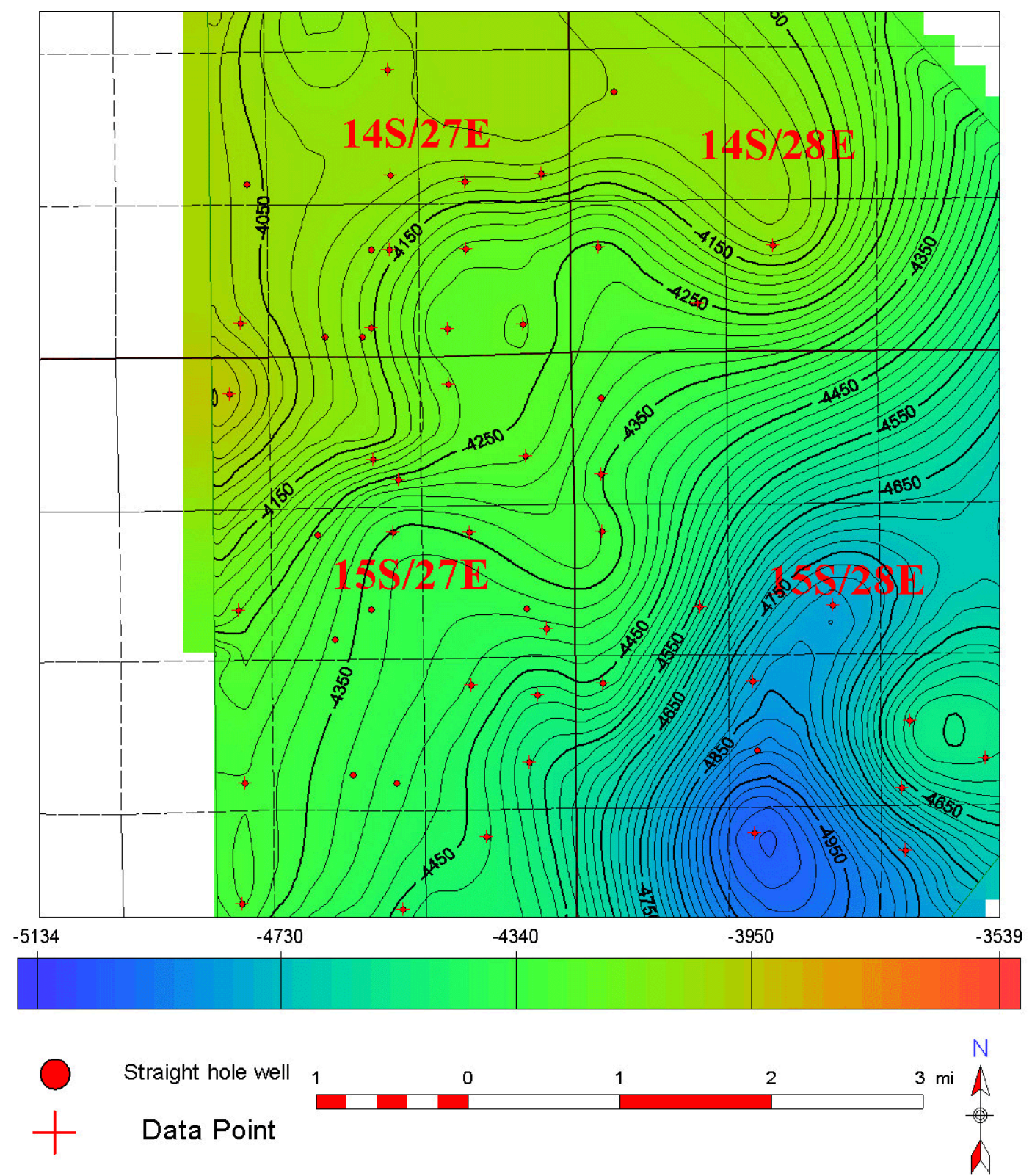

Figure 3.18: Subsea structure map on the top of the Strawn Formation. Contour interval, $20 \mathrm{ft}$. 

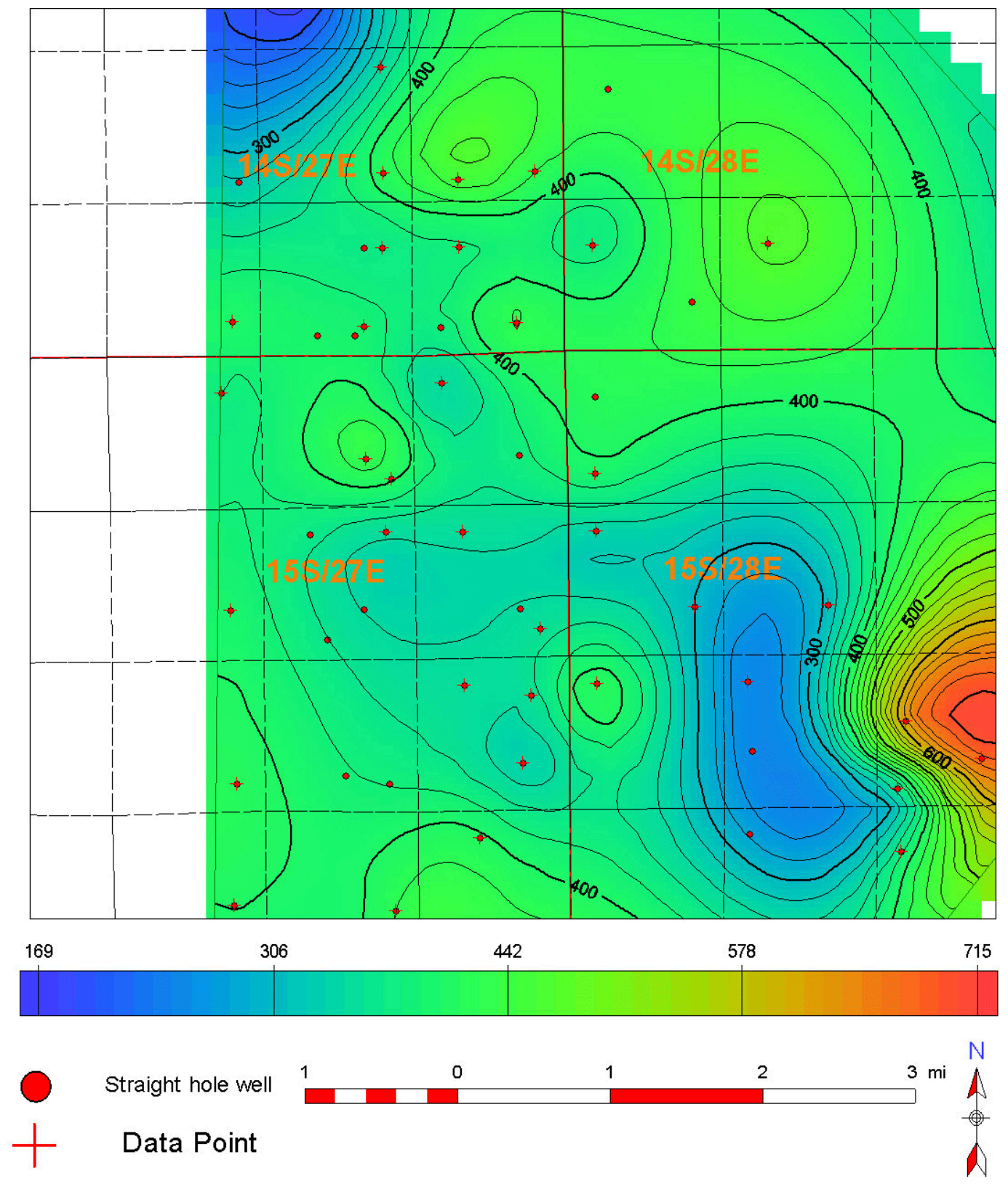

Figure 3.19: Isopach of the Strawn Formation. Contour interval, $20 \mathrm{ft}$. 


\subsubsection{Cisco and Canyon formations}

The Cisco and Canyon formations represent cyclical trangressive and regressive sequences (Hills and Galley, 1988). Subsea elevations to the top of the Cisco range from $3200 \mathrm{ft}$ to $3800 \mathrm{ft}$. Cisco structure is similar to that observed on the Atoka; the structure is marked by a NE-SW strike and southeast dip (Figure 3.20). The low observed in the Strawn to the southeast is occupied by nose- or shoulder-like ridges that extend to the southeast. The structural nose observed in deeper Atoka reappears in the Cisco Formation.

The Cisco-to-Strawn isopach reveals a rough trend of north-to-south thickening that occurs at an angle to regional strike (Figure 3.21). Pronounced local thickening observed in the southeast corner of the area appears to be associated with the structural nose and adjacent trough observed in the structure map. Overall, the axis of subsidence appears to have shifted to the south during deposition of the Cisco-Strawn interval. The zone of thickening coincides with infilling of the structural low in the Strawn and elevated structure on the surface of the Cisco.

The isopach map of the entire Pennsylvanian interval (Top of the Cisco- toChester plus the Barnett Shale) reveals a general south-southeast thickening trend (Figure 3.22). A wedge of thicker sediments also extends south-southeast through the center of the area. In the regional context, this zone of thickening follows the regional north-south oriented trend of a pre-existing zone of weakness described by Hills and Galley (1988). The steepened thickness gradient in the western part of the area suggests the possibility of syndepositional growth across a deeper fault that continued to Upper Pennsylvanian time. 


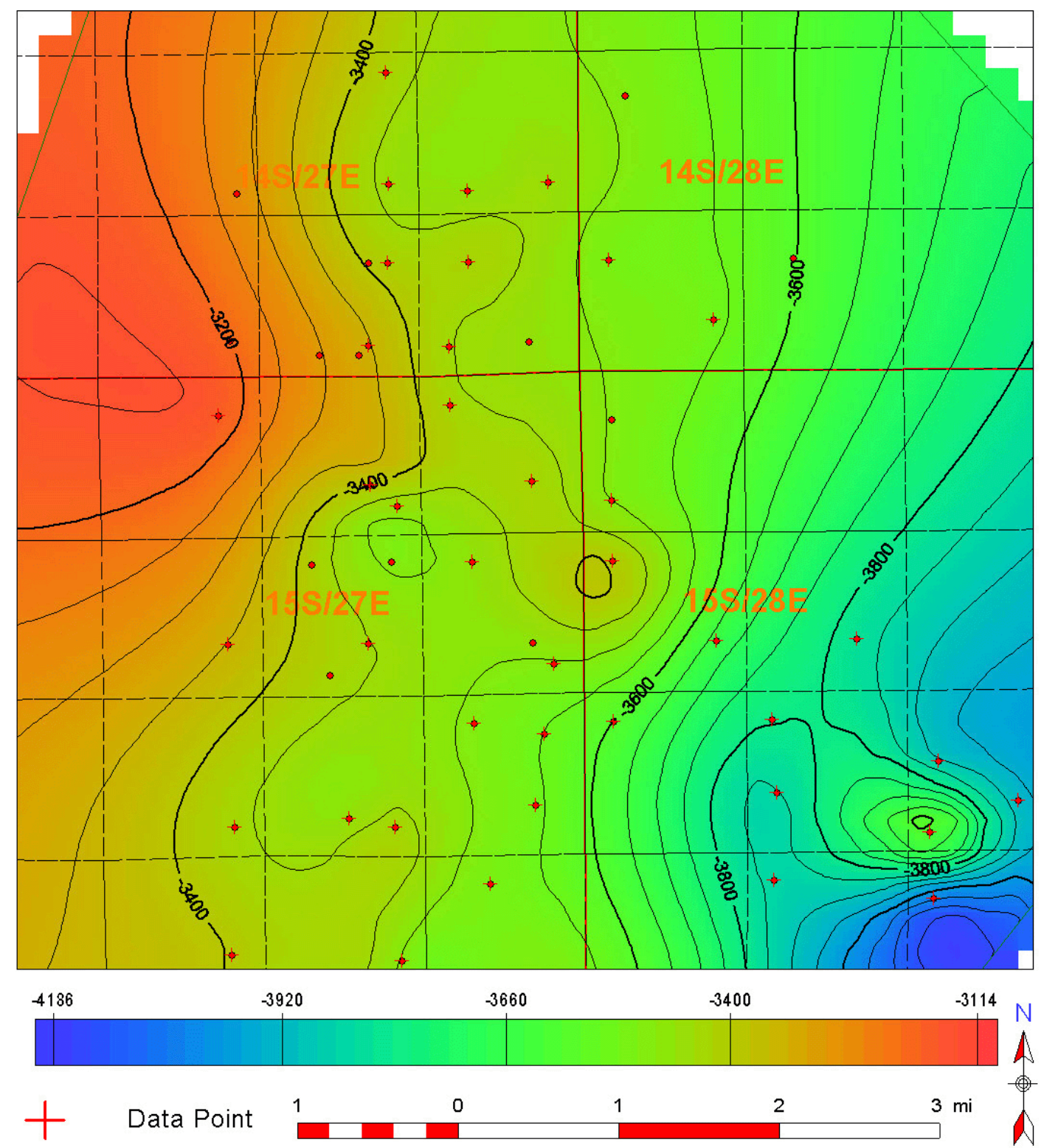

Figure 3.20: Subsea structure on top of the Cisco Formation. Contour interval, $50 \mathrm{ft}$. 


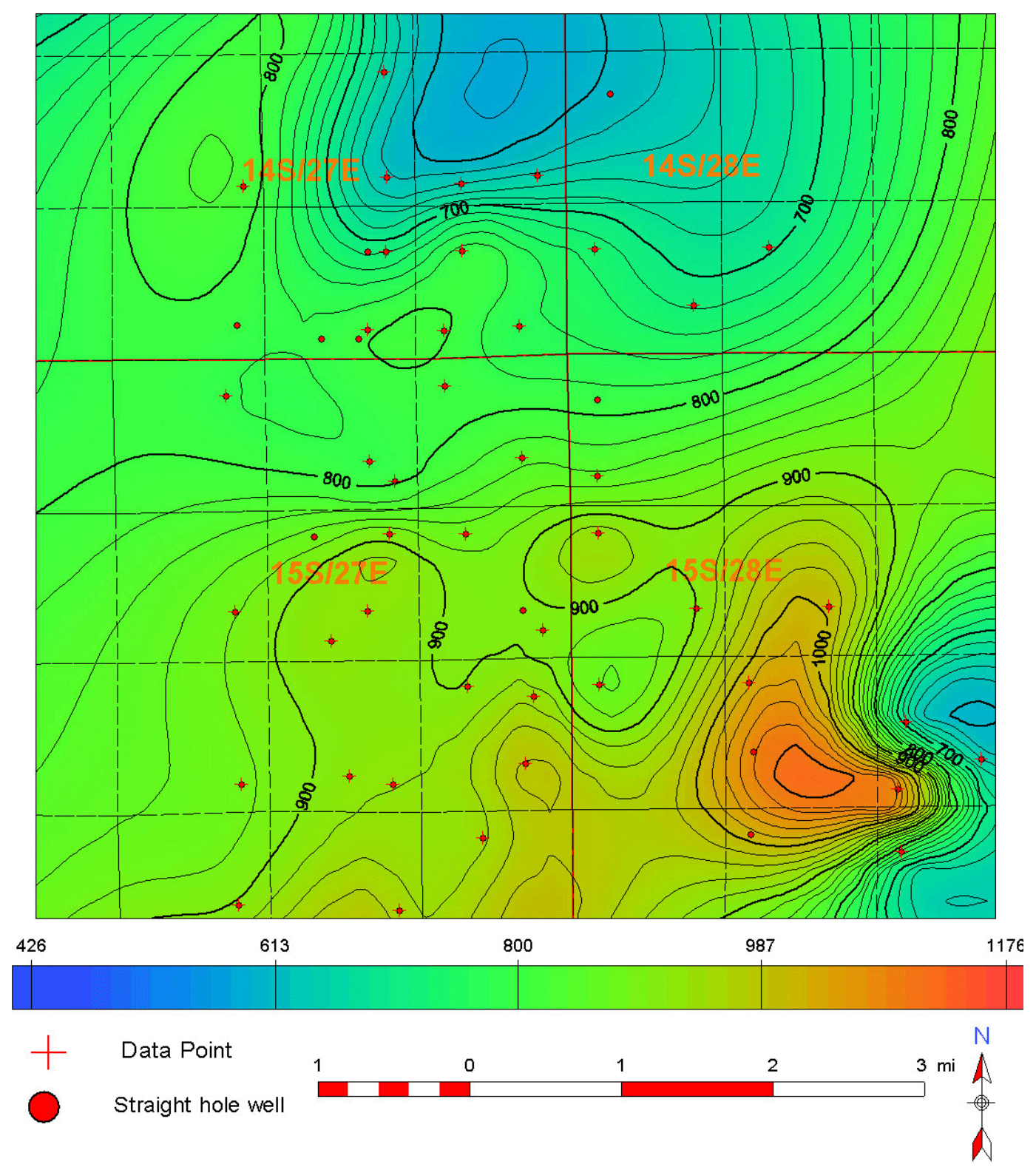

Figure 3.21: Isopach from the top of the Cisco Formation to the top of the Strawn Formation. Contour interval, $20 \mathrm{ft}$. 


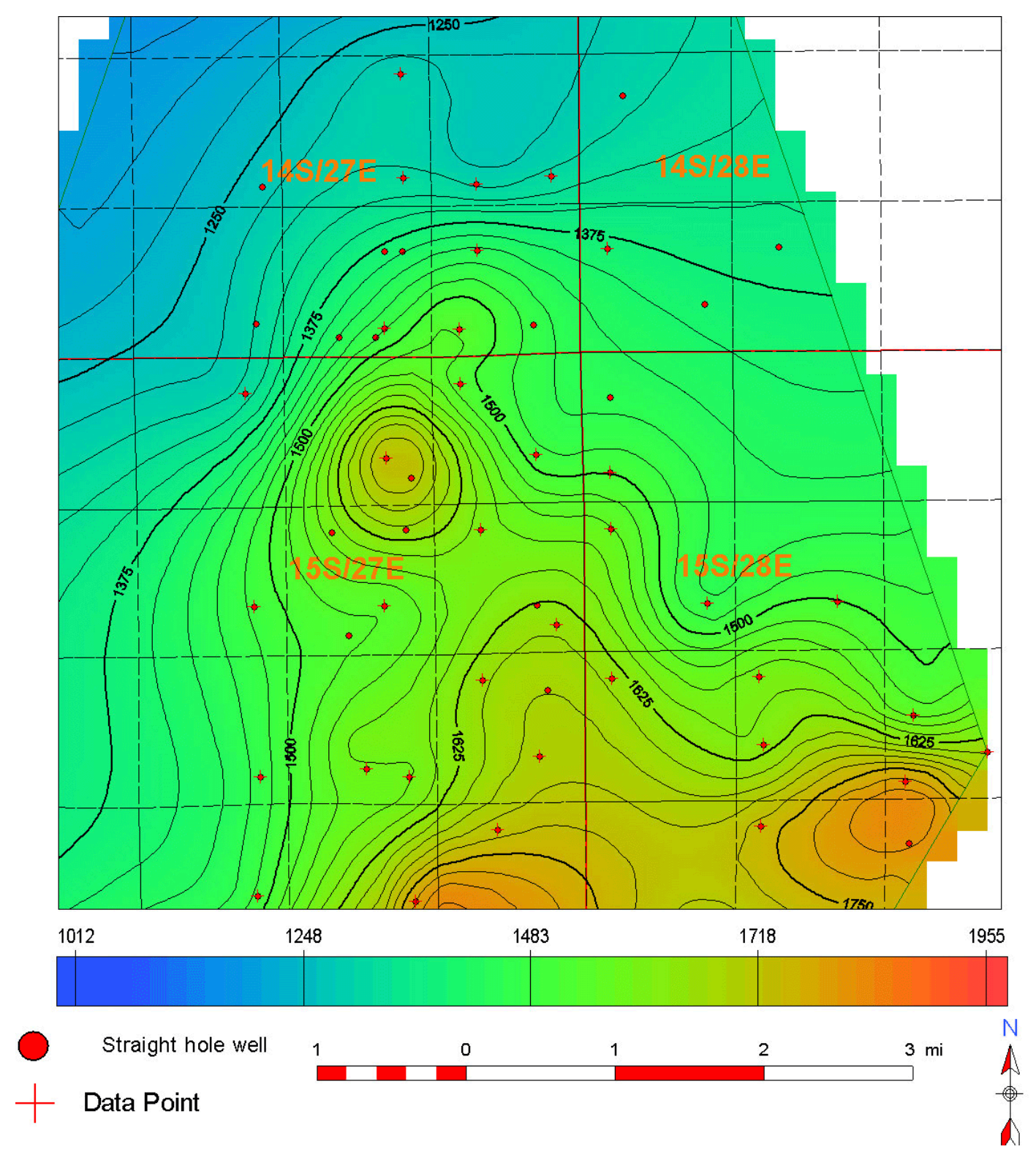

Figure 3.22: Isopach of the Pennsylvanian interval including the Barnett Shale. Contour interval, $25 \mathrm{ft}$. 


\subsubsection{Wolfcamp Formation and Glorietta formations}

Structure on the top of the Wolfcamp Formation (Figure 3.23) has northeastsouthwest strike with regional dip to the southeast similar to the underlying formations. Subsea elevations range from $2400 \mathrm{ft}$ to $2980 \mathrm{ft}$. The isopach of the Wolfcamp Formation (Figure 3.24) reveals a pronounced belt of thickened section that trends nearly northsouth in the northern part of the area before bending to the northeast. The area to the southeast is defined by two wells that suggest thickening in excess of $1000 \mathrm{ft}$ in this area.

The structure map on the top of the Glorietta Formation is illustrated in Figure 3.25. Elevations at the top of the Glorietta range from $1000 \mathrm{ft}$ to $150 \mathrm{ft}$ above sea level. The structure on Glorietta is more irregular than that on the underlying Wolfcamp. A pronounced structural depression cuts through the center of the area that opens into an expansive low to the east and southeast. Isopach of the Glorietta-to-Wolfcamp interval (Figure 3.26) shows features related to structure on the top of the Glorietta. A thicker north-south trend coincides with a north-south trending structural ridge (Figure 3.25). The structural low in general, coincides with an area of thinner Glorietta. In contrast to the southeast thickening trend of the lower Permian and Pennsylvanian intervals, the isopach of the Glorietta-Wolfcamp interval shows thickening in the northern part of the study area. This thickening across the northern part of the area appears to be associated with elevated structures on the Glorietta relative to that on the underlying Wolfcamp. Thickening in the south-west corner outside of the seismic survey area is also observed. Thickening to the north and south may have been produced by local uplift through the center of the area deposition. If so, a later episode of subsidence would be required to drop the thinned section relative to the structural highs northeast and southwest. 


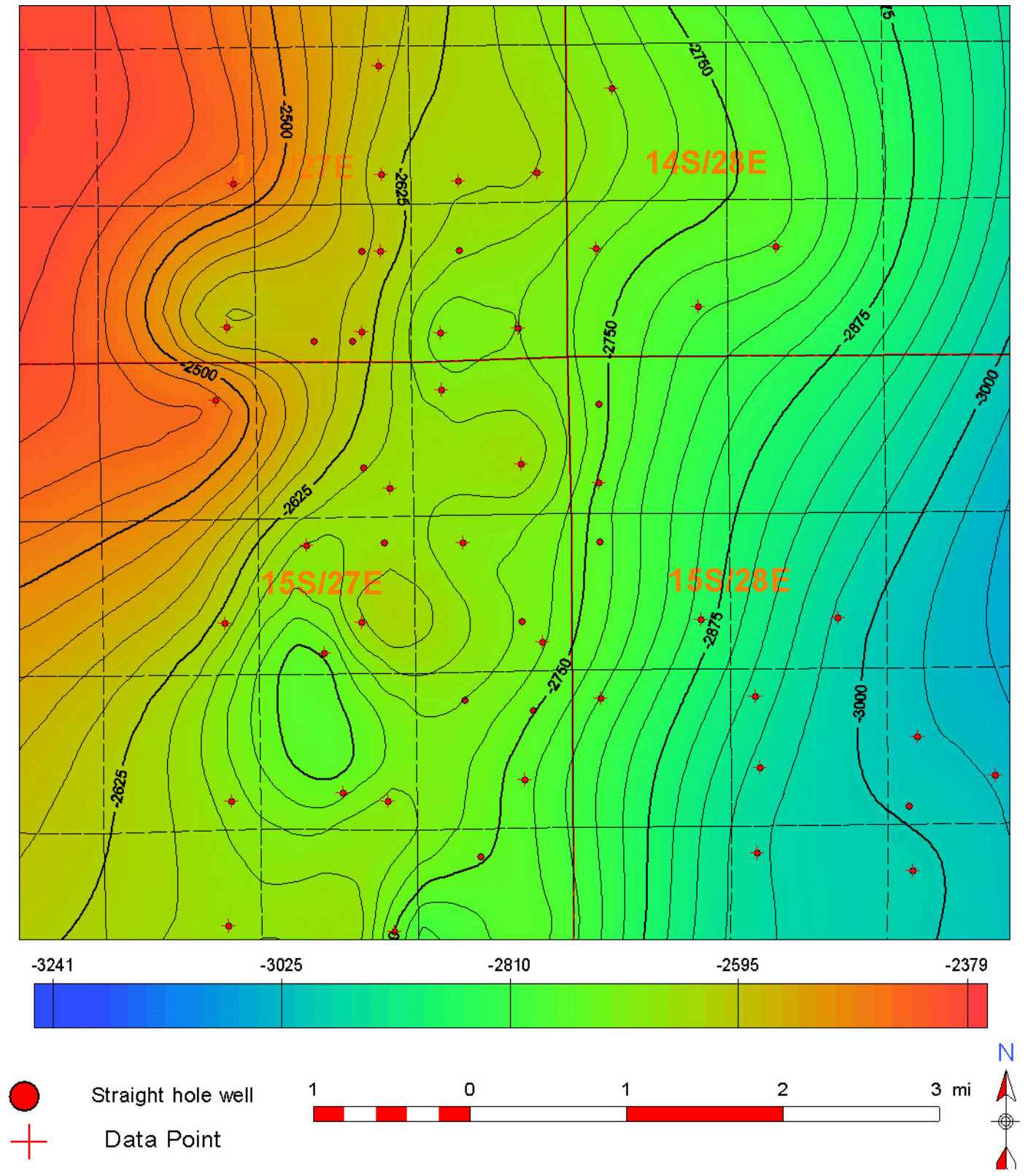

Figure 3.23: Subsea structure on top of the Wolfcamp Formation. Contour interval, $25 \mathrm{ft}$. 


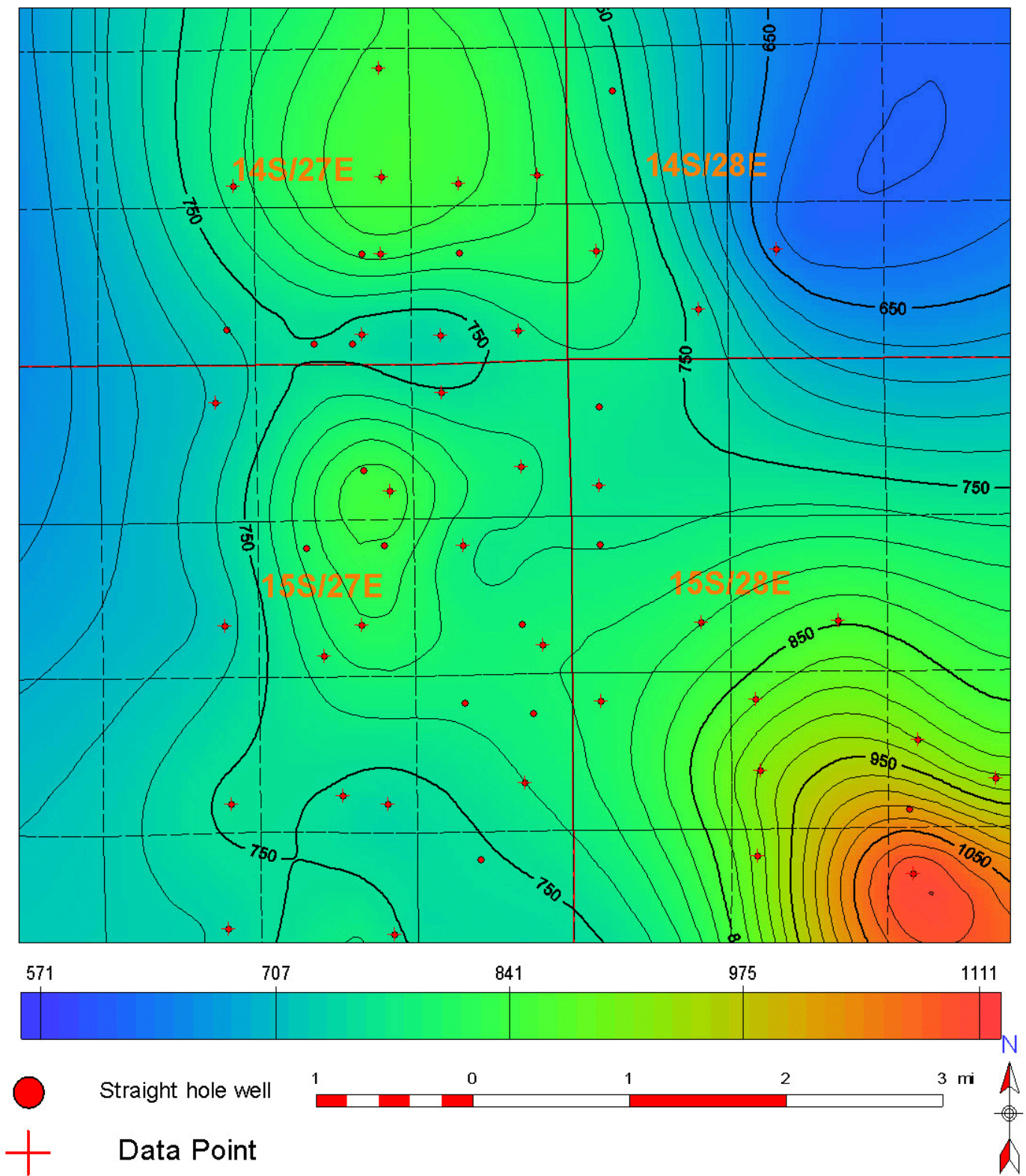

Figure 3.24: Isopach of the Wolfcamp Formation. Contour interval, $20 \mathrm{ft}$. 


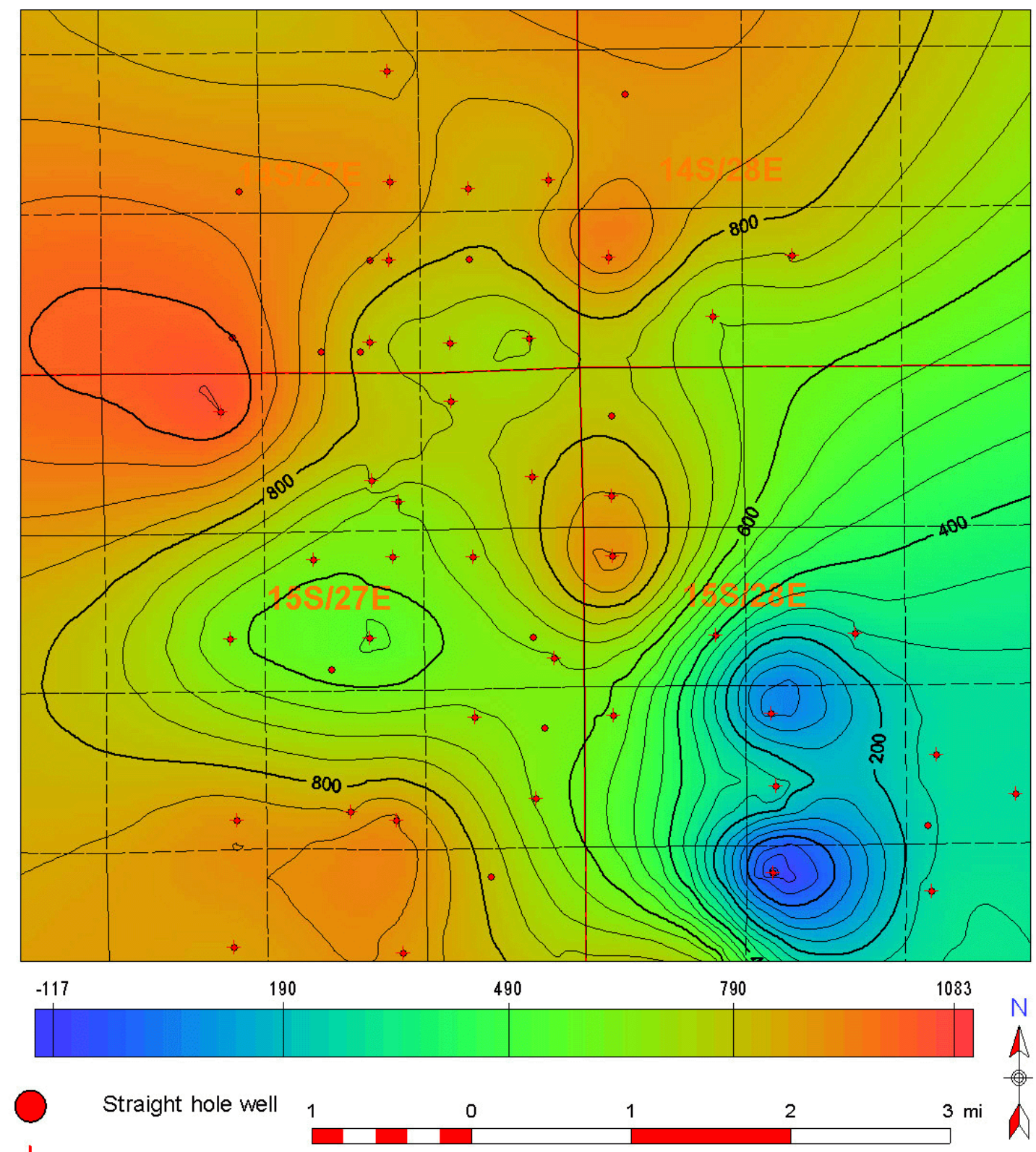

$+\quad$ Data Point

Figure 3.25: Structure on top of the Glorietta Formation. Contour interval, $50 \mathrm{ft}$. 


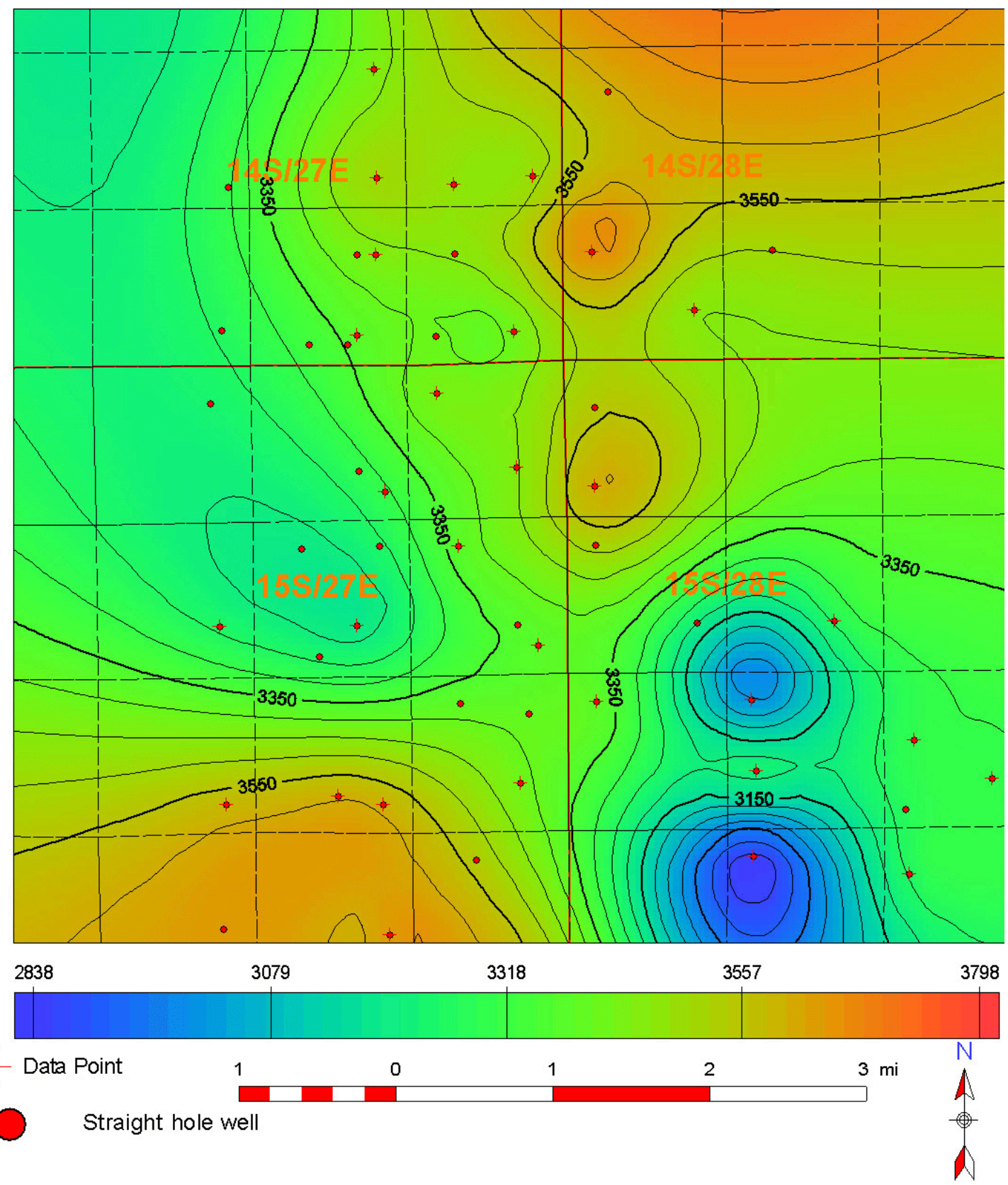

Figure 3.26: Isopach of the top of the Glorietta-to-top of the Wolfcamp interval. Contour interval, $50 \mathrm{ft}$. 


\subsection{The Morrow Channel Sand}

The Morrow channel sand in the Buffalo Valley area is referred to as the Harris Channel (Roswell Geological Society Volume, 1993). As discussed in section 3.1, Morrow production is from the Morrow sands of the Lower Morrow. These sands were deposited as part of a meandering fluvial channel system flowing from northwest to the southeast through the region (Mazzullo, 1999 and James, 1985). The source area for these sands was the Pedernal uplift to the northwest (James, 1985). James (1985) also notes there was some influx of sands from the uplift of the Central Basin Platform to the east along the eastern margin of the Delaware Basin.

The Buffalo Valley channel sands have average density of $2.5 \mathrm{~g} / \mathrm{cc}$ and average porosity of 8-10 \% (Sanchez, 2005). The average sand thickness ranges from 5-30 ft. Based on the resolution limits of the seismic data examined in Chapter 4, the top and base of these channels cannot be resolved as distinctly separate reflection events. The Harris Channel is difficult to identify in well logs due to limited well coverage and the poor quality of many of the older logs. This made it difficult to prepare an accurate net sand map for the Morrow. As an alternative, the thickness of the underlying Barnett Shale was mapped. The high gamma response of the Barnett Shale makes it easy to map. Since the Harris Channel represents a valley fill deposit that cut into the underlying Barnett Shale, it was suggested (Oldham, personal communication) that thinner Barnett Shale intervals would result from channel scour and help identify the aerial distribution of the channel. Hence, an isopach map of the Barnett Shale was computed, and based on this isopach, the thickness of the lower Morrow channel sand was interpreted. 
Oil production data from the Buffalo Valley field was used to assess the possible linkages between the oil production and seismic response in the field. It was also used as a guide to roughly infer the channel sand location. Production in the Buffalo Valley field from the Harris Channel sand was calculated using data obtained from the New Mexico Tech "Go-Tech" site at http://octane.nmt.edu/data/ongard/. Production data could be found only for 57 wells out of a total of 110 wells within the Buffalo Valley area. The annual cumulative production for four wells is illustrated in Figure 3.27. The figures show significant drop in production after a 5 to10 year period. Based on these figures it was decided that a five-year cumulative production map would help to define the major producing trends in the area. A typical example of the monthly production variation is shown in Figure 3.28 for an 8 year period for the Lula-3 well (API no. 3000560481).

Oil production in the Buffalo Valley field is shown in Figure (3.29). The average 5-year cumulative production per well calculated from 57 wells in the field is 4842.07 Bbl. An arcuate belt of high production extends towards the southeast through the northern half of the field and then swings into a nearly east-west trend before turning south near the southwest corner of the area. This overall belt of high production defines the Harris Channel as it meanders through the area. The interruption along this trend in the middle of the area may be related to the segmentation of the channel or perhaps to the presence of a low porosity channel, typical of the meandering channel system.

The Barnett Shale isopach (Figure 3.30) reveals thickness variations from a minimum of $20 \mathrm{ft}$ to maximum of $90 \mathrm{ft}$. The minimum thickness trend correlates well to the high production trends. The thinner Barnett Shale zone appears to be a reliable indication for the presence of the Harris Channel. Polygons outlining thinned intervals 

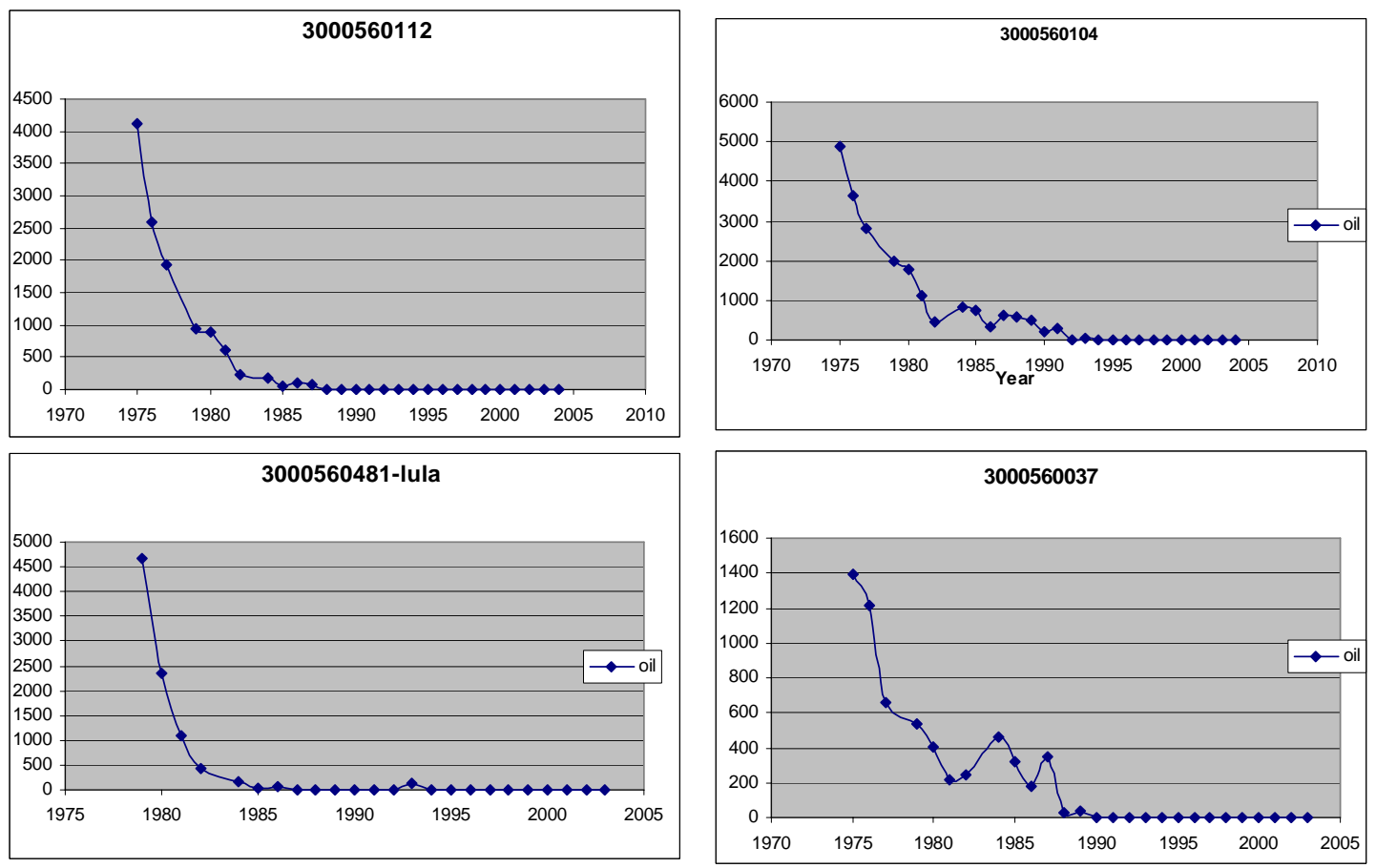

Figure 3.27: Yearly production figures for the selected wells in the Buffalo Valley field.

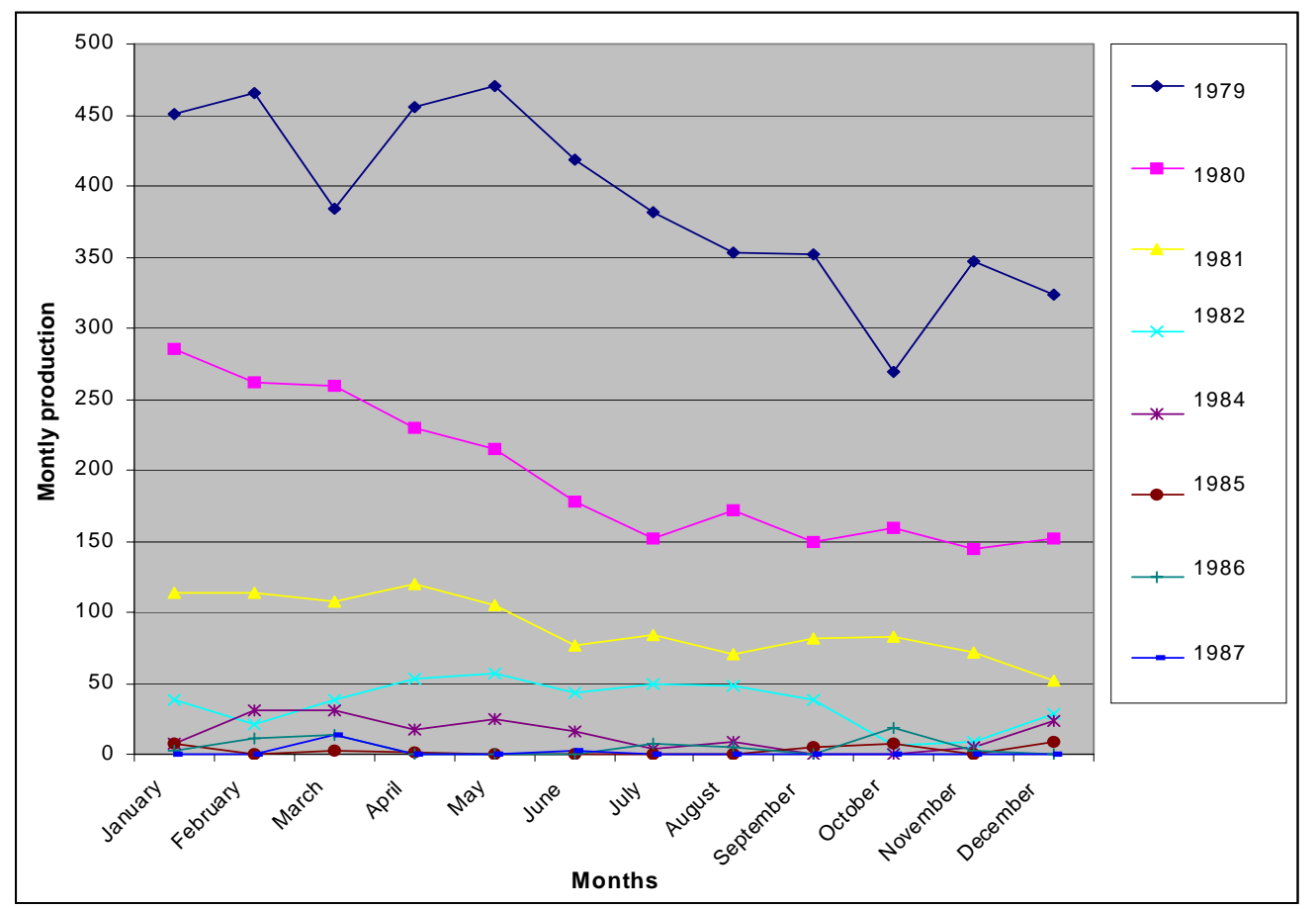

Figure: 3.28 Monthly cumulative production of Lula3 (3000560481) Well from 1979 to 1987. 


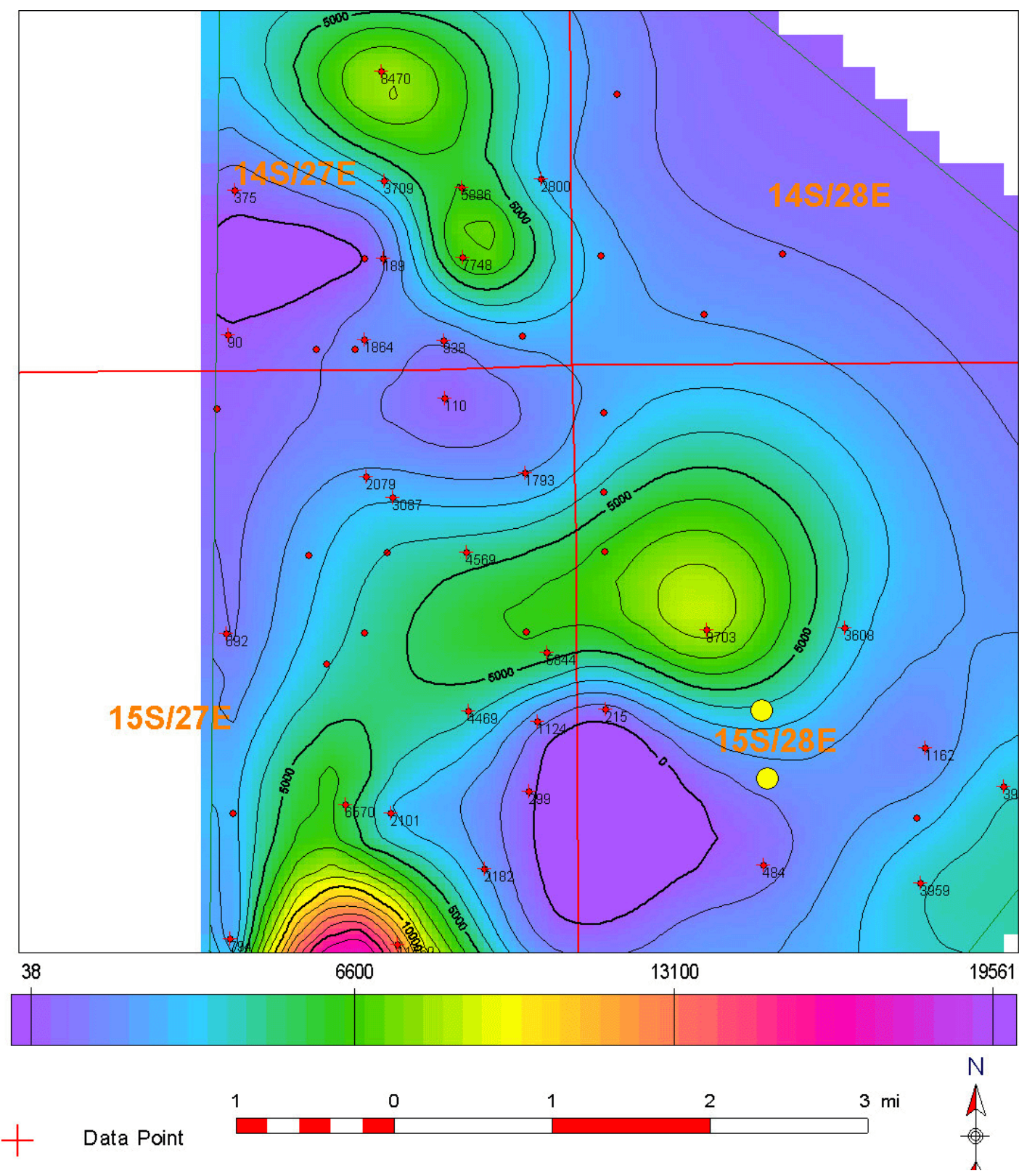

Figure 3.29: Five year cumulative oil production. The highlighted yellow dots locate two wells with very high production. These wells were omitted from the contoured data. Greenish to yellow shades represent the majority of high production in the field. 



Figure 3.30 : Isopach of the Barnett Shale. Contour interval, $10 \mathrm{ft}$. 
were digitized from the Barnett Shale isopach map. These polygons were then overlain on the production map to illustrate the quality of agreements between the thinned Barnett Shale and high oil production trend (Figure 3.31). The correlation provides strong support for the interpretation that the area of thinned Barnett Shale corresponds to the location of the Harris Channel.

A polygon representing thinned Barnett Shale zones is overlain on the $2^{\text {nd }}$ order residual structural map of the Chester Formation (Figure 3.32). The result showed little relationship between the Chester residual and the thinned areas in Barnett Shale. In general, the Barnett thins are aligned with a residual high to the east of the area along the northwest-southeast trend. There is some alignment with the residual high to the southwest.

Similarly, no clear relationship between production and structure in the underlying Chester is observed (Figure 3.33). Some channel segments are located over structural highs and some over relative lows or along steepened structure gradients (Figure 3.33). However, the Harris Channel deviates from an expected NW-SE trend normal to the early Pennsylvanian shoreline. The course of the channel may have been deflected into a more north-south trend along the fold axis. Hints of North-South oriented faults in the Atoka and Chester structure and isopach may be related to underlying structural controls during the channel movement and migration during Morrowan time. In the seismic interpretation presented in Chapter 5, north-south trending faults border the field on the east and west. The well log derived structure suggests faults may be present but do not clearly define their location and extent. 


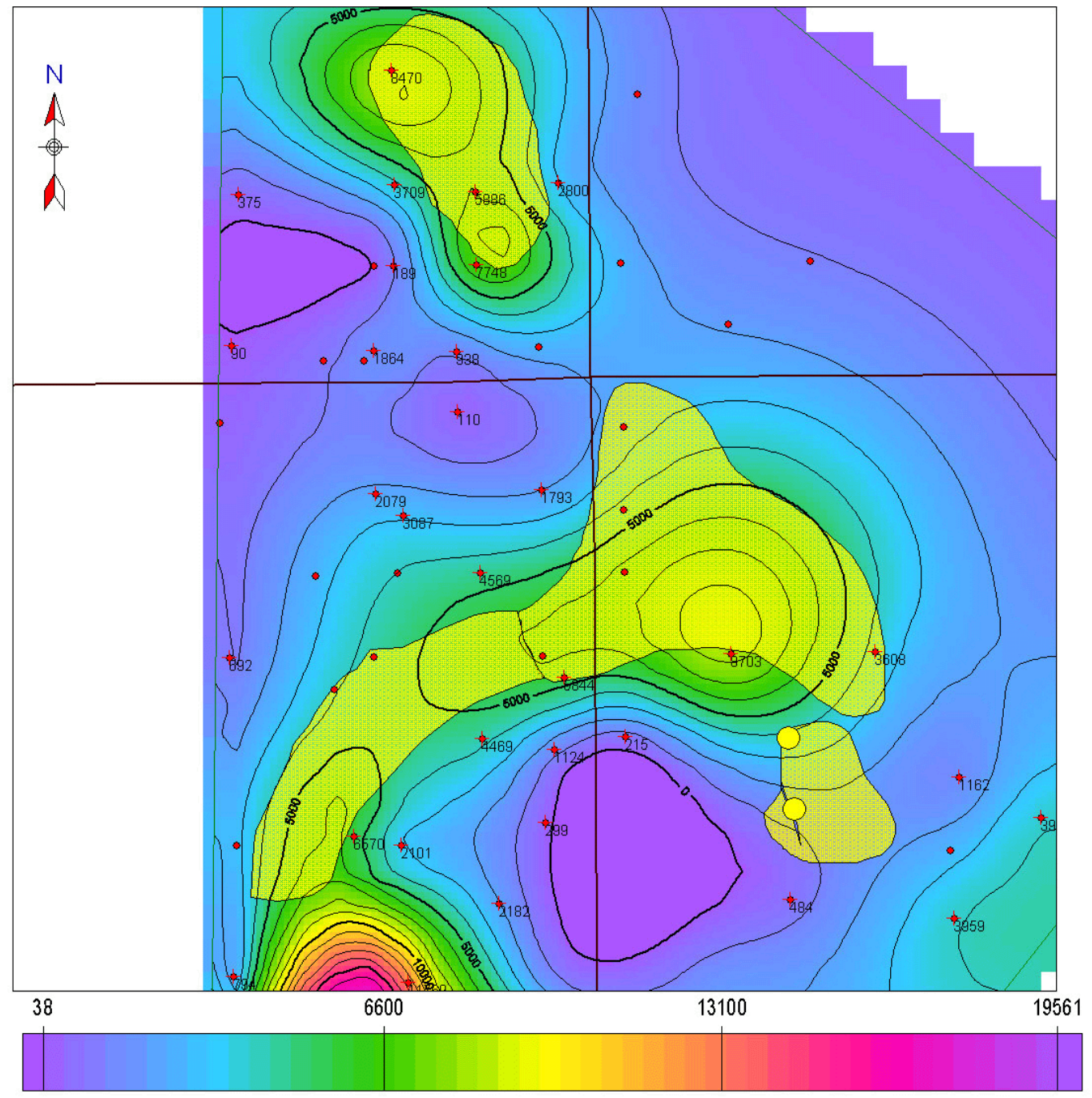

Figure 3.31: Vector overlay of thinned zones in the Barnett Shale (shown in yellow) are superimposed on the production map. 


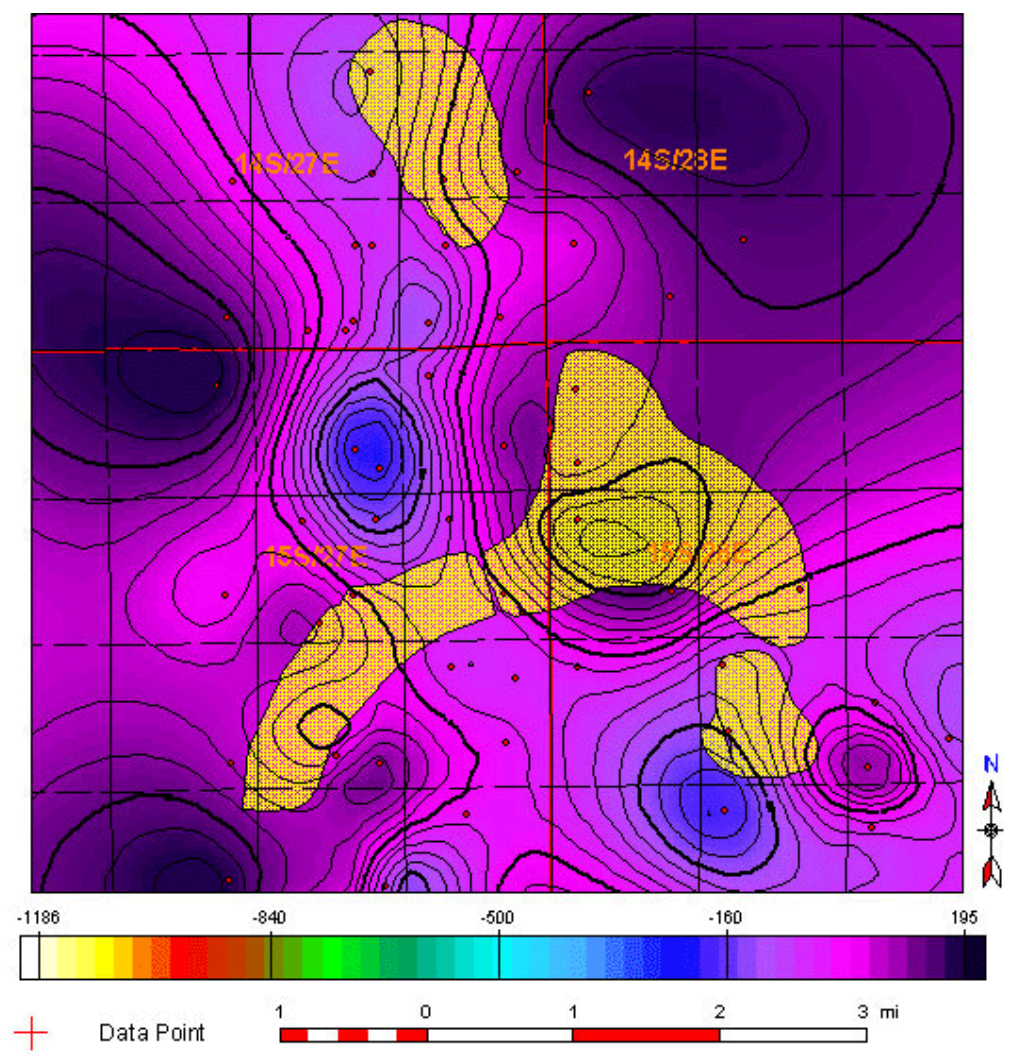

Figure 3.32: Thinned areas in the Barnett shale are superimposed on the $2^{\text {nd }}$ derivative map on the Chester structure. Contour interval, $25 \mathrm{ft}$.



Figure 3.33: Areas with high oil production (shaded polygon) are superimposed on the Chester structure. Contour interval, $25 \mathrm{ft}$. 


\section{CHAPTER 4}

\section{SEISMIC RESOLUTION}

\subsection{Introduction}

The ability to resolve stratigraphic environments in seismic data sets generally depends on its bandwidth and wavelet phase. The limited spectral content of a seismic data set imposes inherent limits on the seismic interpretation of stratigraphic features both laterally and vertically. The target interval of this study is the Morrow channel sand, locally referred to as the Harris Channel. This sand is relatively thin (5-30 ft thick), laterally discontinuous, and generally un-resolvable in the seismic data set. The seismic resolution limits of a given data set specify the minimum horizontal and vertical dimensions of the target body that can be precisely delineated at a specific depth or twoway travel time. Resolution is often evaluated in terms of the spectral properties of the seismic wavelet and should be fully considered in the analysis and interpretation of stratigraphic features in the seismic data. An appreciation of these inherent resolution limits is critical to objective seismic stratigraphic interpretation.

\subsection{Theory}

An evaluation of seismic resolution limits addresses basic questions concerning the ability of the seismic dataset to resolve the top and bottom of a layer as distinctly separate reflections, and the ability of the seismic data to accurately resolve the lateral extents of stratigraphic elements. 
Sheriff (1999) defined resolution as "the ability to tell that more than one feature is contributing to an observed effect.” Resolution limits are specified in terms of the minimum vertical and horizontal dimensions of an object that can be resolved. The vertical resolution limit defines the minimum thickness of a layer for which the reflection from the top is distinctly separate from the reflection from the base. The vertical resolution limit depends upon the thickness of a layer, its interval velocity and impedance contrasts within the bounding layers (Sheriff and Galadart, 1999). The fundamental attributes of the seismic data which limit its ability to resolve the top of a layer from its base are its bandwidth and dominant frequency. The frequency and bandwidth relationship is illustrated for an idealized spectrum in Figure 4.1.

The dominant time period $\left(\tau_{\mathrm{d}}\right)$ corresponds to the time interval between wavelet side lobes (Figure 4.2). The reciprocal of $\tau_{d}$ gives the dominant frequency $\left(f_{d}\right)$ of the signal i.e., $f_{d}=1 / \tau_{d}$. The dominant frequency $\left(f_{d}\right)$ normally does not equal the peak frequency $\left(f_{p}\right)$ unless the spectrum has symmetrical shape (Figure 4.1).

The reciprocal of bandwidth provides a measure of wavelet duration. Bandwidth ( $\mathrm{f}_{\mathrm{b}}$, Figure 4.1) is defined as the frequency range between half-power points or 0.707 amplitude points. The bandwidth is inversely proportional to wavelet duration. Wavelets with high dominant frequency and small bandwidth have numerous short-period high amplitude side lobes.

The vertical resolution limit is often expressed as a function of the dominant period. At the resolvable limit, the separation of reflection events from the top and base of a reflected layer corresponds to one half the dominant period (i.e. $1 / 2 \tau_{d}$ ). This also corresponds to the time separation between the peak and adjacent trough of a seismic 


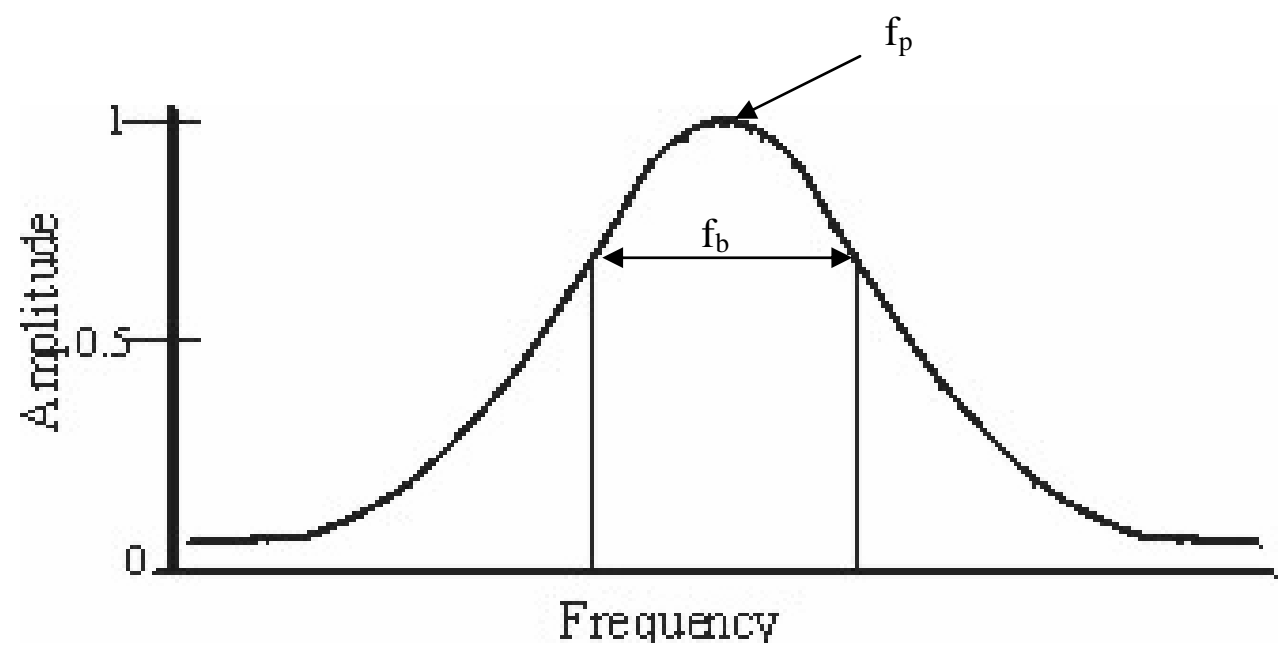

Figure 4.1: Amplitude spectrum showing amplitude versus frequency. Bandwidth in this study is defined as the range of frequencies separating 0.707 of the amplitude points (i.e. half power points) in the spectrum.

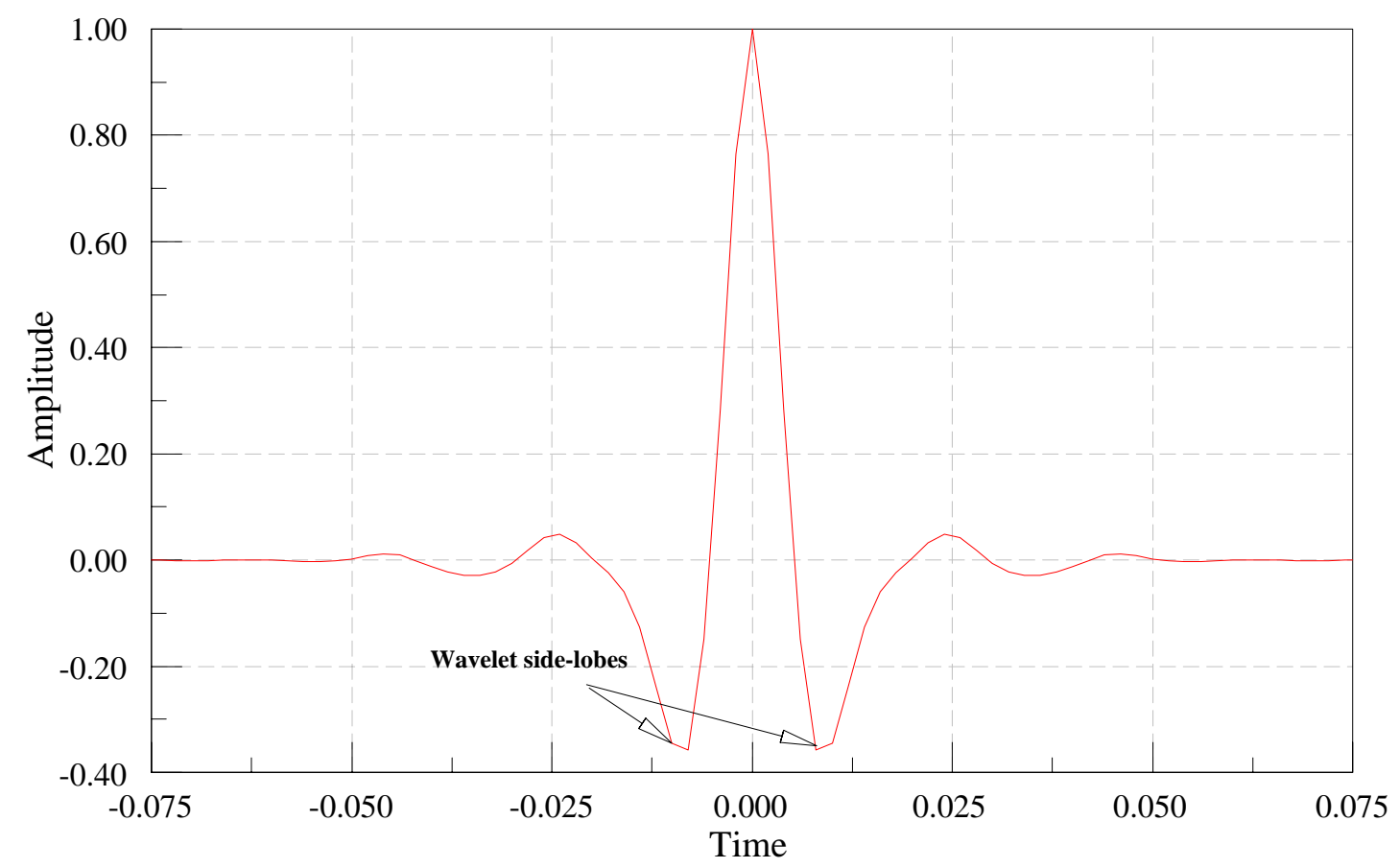

Figure 4.2: The dominant period $\tau_{\mathrm{d}}$ is the time interval separating side lobes in the zero phase wavelet shown above. 
wavelet (i.e. $\tau_{\mathrm{d}} / 2$ in Figure 4.2). The resolvable limit also corresponds to the layer thickness that produces maximum constructive interference between reflections from the top and base of the layer. This thickness is also known as the tuning thickness. The minimum resolvable thickness (T) can be estimated using the relationship $v \tau_{d} / 2$, where " $\mathrm{v}$ " is the interval velocity of the layer in question.

In the case of horizontal resolution, the resolution limit is defined by the radius of the Fresnel zone. The Fresnel zone radius defines the minimum resolvable radius of a disk shaped object. Mathematically, the horizontal resolution limit ( $\left.R_{F}\right)$ is given as, $\mathrm{R}_{\mathrm{F}}=\frac{\mathrm{V}_{\mathrm{Rms}}}{2} \sqrt{\tau_{d} \times t} \quad$ (modified after Badley 1985). $\mathrm{R}_{\mathrm{F}}$ is the radius of the Fresnel Zone, $\tau_{\mathrm{d}}$ is the dominant period of the seismic data in the zone of interest and $\mathrm{v}_{\mathrm{Rms}}$ in this case is the rms velocity. The relationship of the Fresnel zone radius as a function of frequency and depth is illustrated in Figure 4.3.

Figure 4.3 illustrates that the Fresnel zone radius decreases with increased frequency. Similarly, the Fresnel zone radius increases with increased depth. Attenuation of seismic waves as they travel through the Earth varies as a function of frequency. Amplitude attenuation increases with frequency. Attenuation denotes the energy loss of the seismic waves as they travel away from the source. The amplitude of the seismic wave at a distance $r$ from the source is given as,

$$
\mathrm{A}(\mathrm{r})=\mathrm{A}_{0} e^{-\alpha r}
$$

where, $A_{0}$ is the amplitude at the source and $\alpha$ is the attenuation factor which can be written as,

$$
\alpha=\frac{\pi f}{Q v}
$$





Figure 4.3: Relationship of Fresnel zone radius to depth (A) and frequency (B).The Fresnel zone radius was computed using a velocity of $15860 \mathrm{ft} / \mathrm{s}$ (velocity of the Harris Channel) and frequency of $66.66 \mathrm{~Hz}$. 
Here, $\mathrm{Q}$ is an absorption constant (known as the quality factor) proportional to the reciprocal of the energy dissipated over one cycle, and $f$ and $v$ are the frequency and velocity of the wave respectively. The above relationship also shows that the amplitude of the seismic waves progressively decreases symmetrically with distance traveled. The formula for $\alpha$ reveals that attenuation increases with $\mathrm{f}$ and varies inversely with $\mathrm{Q}$. Thus as depth and two-way travel time increases, the dominant frequency in the seismic data becomes progressively lower. The lower dominant frequency results in reduced horizontal $\left(\mathrm{R}_{\mathrm{F}}\right)$ and vertical $(\mathrm{T})$ resolution limits.

\subsection{Resolution of the Atoka-Morrow Interval}

Horizontal and vertical resolution limits for the Atoka-Morrow interval were estimated in the vicinity of the Lula 3 well. An amplitude spectrum (Figure 4.4) was generated from 736 traces around the Lula 3 well taken from segments of 23 lines each having 32 traces. The spectrum was generated from a 0.2 second time window that extended from 0.95 seconds to 1.15 seconds. This time window included reflections from the Atoka at 1.041 seconds and the Morrow at 1.059 seconds. Spectra were generated for both P-wave and PS-wave data sets (Figure 4.4a and 4.4b). Comparison of the two spectra reveals that the P-wave spectrum has peak amplitude at $47 \mathrm{~Hz}$; the PS-wave amplitude spectrum has peak amplitude at $44 \mathrm{~Hz}$. Both amplitude spectra are asymmetrical. Similarly, bandwidth for P-wave data is $63 \mathrm{~Hz}$ while that of the PS-wave data is only $27 \mathrm{~Hz}$.

The P and PS-wave data are presented for comparison in Figure 4.5. Interval velocity variations in the Atoka and Morrow intervals are illustrated for the Lula 3 well velocity log in Figure 4.6. The lower Morrow channel sand (Harris Channel) illustrated in 
this well is about 15 feet thick. The velocity for this channel sand was estimated to be approximately $15860 \mathrm{ft} / \mathrm{s}$. Similarly, interval velocity for the Atoka interval was obtained by averaging the interval velocity between the top and bottom of the Atoka Formation which was calculated to be $16235 \mathrm{ft} / \mathrm{s}$.

The vertical resolution limit can be estimated in two ways. The first approach utilizes a simple approach to computation discussed earlier based solely on the dominant period and interval velocity of the target interval. The second method incorporates computations of resolvable limit that are based on the shape of the wavelet from the zone of interest. In the first approach, the dominant frequency is often approximated using the peak frequency measured directly from the amplitude spectrum. However, the spectral peak is a good approximation of the dominant frequency only when the spectrum is symmetrical, but can lead to significant error if it is not symmetrical. The potential error resulting from the approximation is illustrated in the following discussion. 


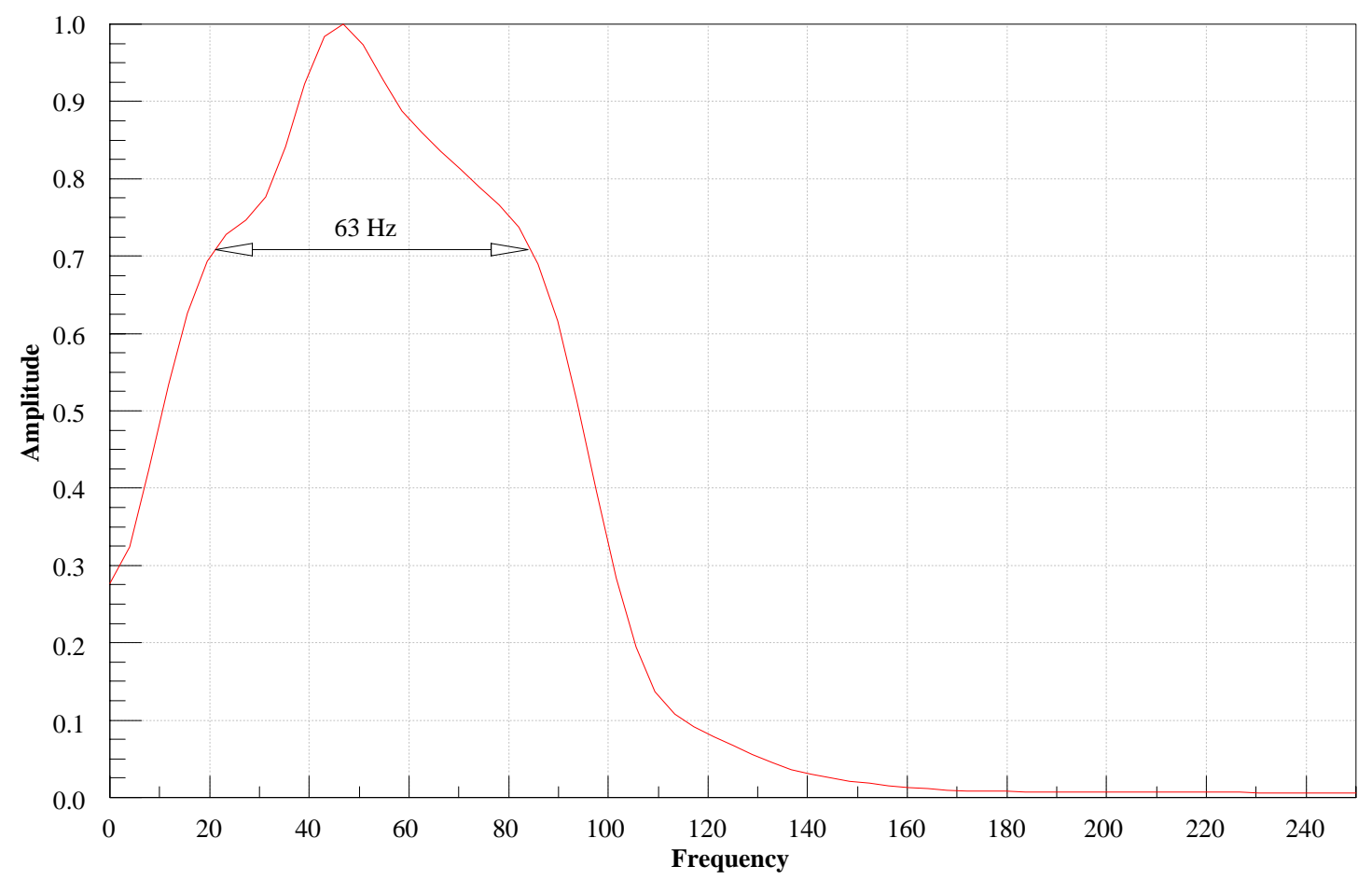

Figure 4.4a: Amplitude spectrum generated for the P-wave data.

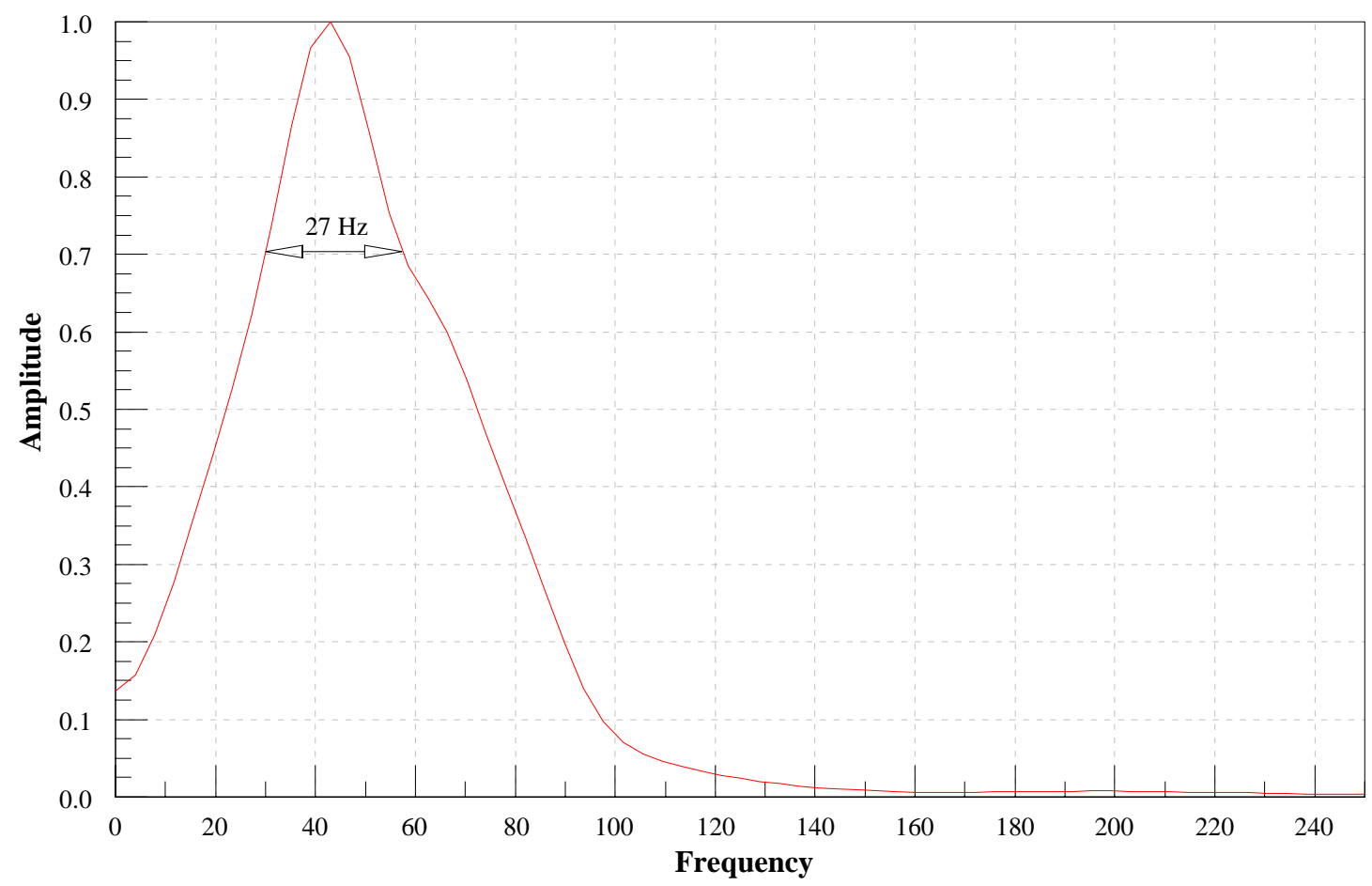

Figure 4.4b: Amplitude spectrum generated for the PS-wave data. 


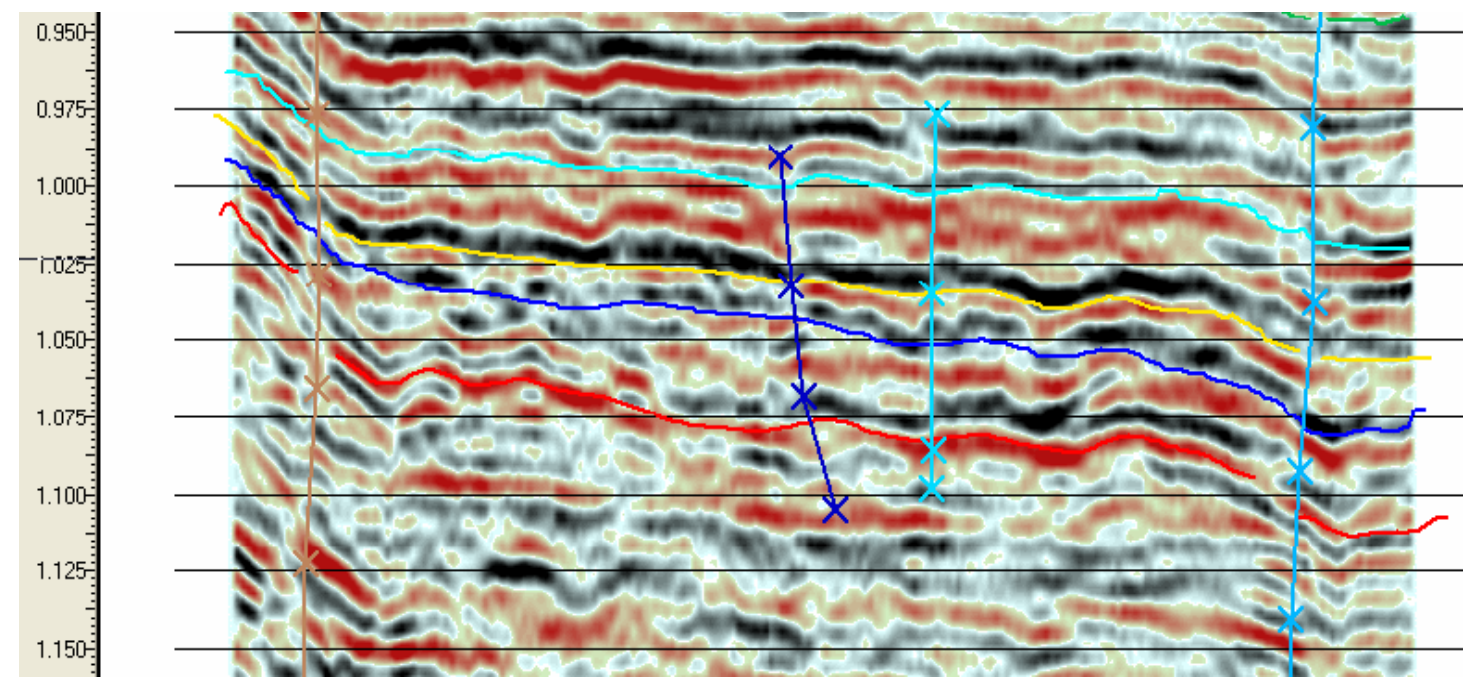

a)



b)

Figure 4.5: Comparison seismic response in a time window extending from 0.95 to 1.15 seconds: a) P-wave seismic response and b) PS-wave response. 


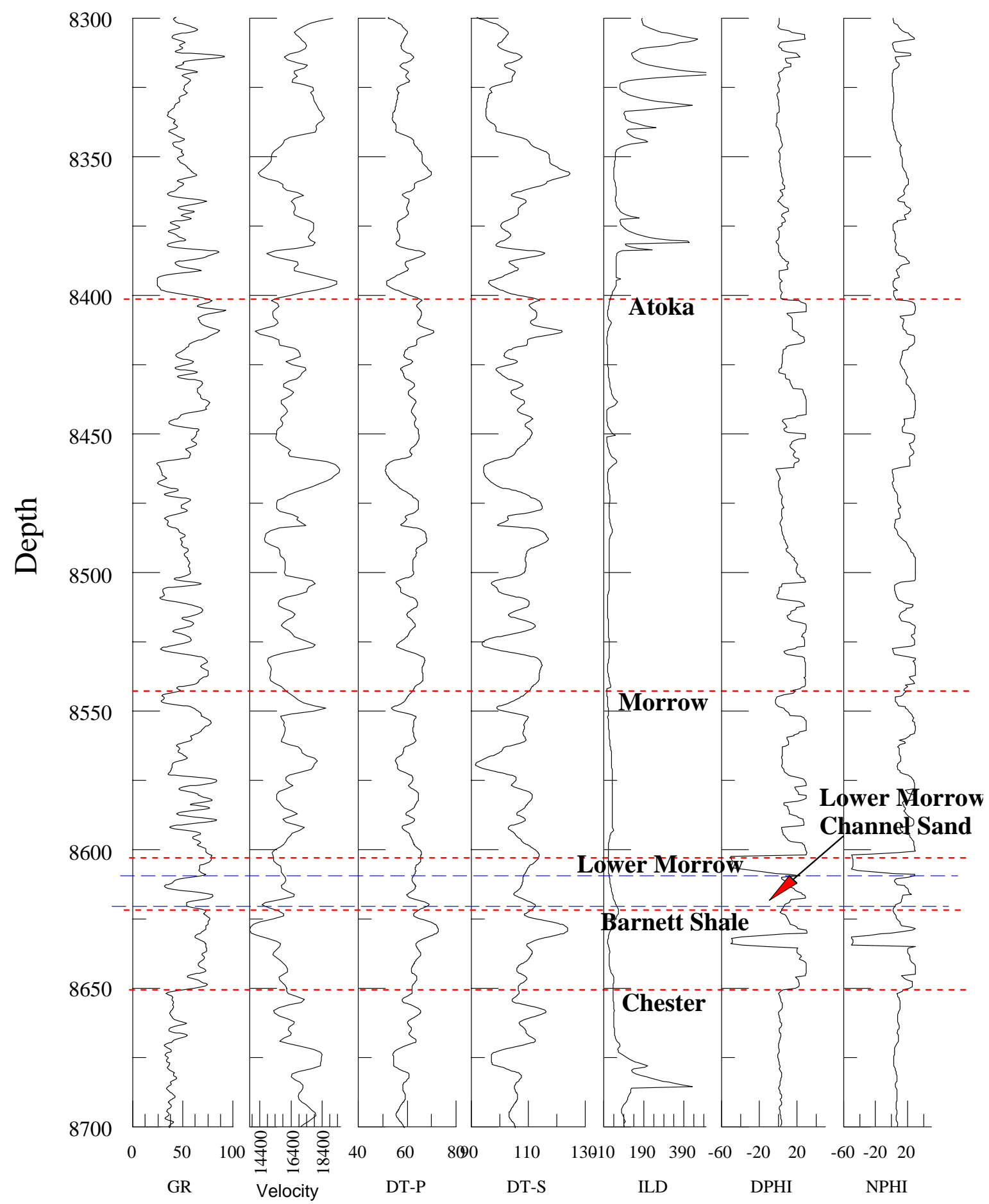

Figure 4.6 : Geophysical logs from the Lula 3 well illustrate the geophysical properties of the lower Pennsylvanian and upper Mississippian strata. (Gr: Gamma ray, DT-P:P wave interval velocity, DT-S: Shear wave interval velocity, ILD: Resistivity, DPHI: DensityPorosity, NPHI: Neutron-Porosity) 
As illustrated in the Figure 4.4, both the P-wave and PS-wave amplitude spectra are asymmetrical but have similar peak frequency. Their peak frequencies were used as dominant frequencies to estimate the resolution limit for the Atoka-Morrow interval as discussed previously. The results of the computations are tabulated in Table 4.1. The results indicate that the P-wave data has slightly better resolution limit (i.e. estimated tuning thickness) than the PS-wave dataset. The tuning thickness for the Morrow sand was calculated to be $84.36 \mathrm{ft}$ using P-wave data, while that for the PS-wave data was $90.11 \mathrm{ft}$.

\begin{tabular}{|c|l|l|l|l|c|}
\hline \multicolumn{5}{|c|}{ Vertical Resolution } \\
\hline \multirow{2}{*}{ Data type } & Interval & $\begin{array}{l}\text { Dominant frequency } \\
\text { estimated from Peak } \\
\text { frequency }(\mathrm{Hz})\end{array}$ & $\begin{array}{l}\text { Interval velocity } \\
(\mathrm{ft} / \mathrm{s})\end{array}$ & $\begin{array}{l}\text { wave period } \\
(\mathrm{s})\end{array}$ & $\begin{array}{l}\text { Tuning Thickness } \\
(\mathrm{ft})\end{array}$ \\
\hline \multirow{2}{*}{ P-wave } & Atoka & 47 & 16235 & 0.0212 & 84.36 \\
\cline { 2 - 6 } & Morrow sand & 47 & 15860 & 0.0212 & 88.56 \\
\hline \multirow{2}{*}{ PS-wave } & Atoka & 44 & 16235 & 0.0227 & 92.24 \\
\cline { 2 - 6 } & Morrow sand & 44 & 15860 & 0.0227 & 90.11 \\
\hline
\end{tabular}

Table 4.1: Vertical resolution limit calculated for the P-wave and PS-wave data using Rayleigh's criteria.

The dominant bandwidths of the two data sets were determined from the frequency range between 0.707 of the amplitude points (i.e. equivalent half-power points). The P-wave data in the analysis window has a bandwidth of $63 \mathrm{~Hz}$, ranging from 21 to $84 \mathrm{~Hz}$. In case of the PS-wave data, the bandwidth is only $27 \mathrm{~Hz}$, ranging from 30 to $57 \mathrm{~Hz}$.

The estimated resolution limits derived from the peak frequencies of the P-wave and PS-wave datasets are quite similar. However, considerable differences in bandwidth and shape of the spectra from these two datasets can be observed (Figure 4.4). The narrower bandwidth of the PS-wave dataset produces broadening in the seismic wavelet 
which leads to an increase in the actual resolvable thickness. The spectral bandwidth and shape exert important control on actual resolution limit.

A second approach to the evaluation of resolution limits incorporates the details of wavelet and spectral shape into the evaluations. For a given wavelet, the apparent travel time separating reflections from the top and base of a thinning layer, and the variation in peak-to-trough amplitude in the composite reflection associated with the thinning layer are calculated. These data are represented in two plots referred to as calibration curves (Figure 4.9) (Neidel and Poggiagliomi, 1977). The calibration curves were generated in Kingdom Suite. In this plot, apparent travel time and peak-to-trough amplitude variation are shown on the lower and upper scale respectively. The vertical scale corresponds to the actual travel time through a layer. Travel times in the figure are one way travel times. The diagonal line ' $\mathrm{A}$ ' depicts apparent versus actual time through the thinning layer. At point B note that the apparent travel time deviates from the actual. The apparent travel time between reflections from the top and base of the layer remains nearly constant at 0.0065 seconds beyond point ' $\mathrm{B}$ '. The idealized relationship is continued beyond point ' $\mathrm{B}$ ' and illustrates the idealized case for which apparent and actual time continue to be the same even though the layer thins. 


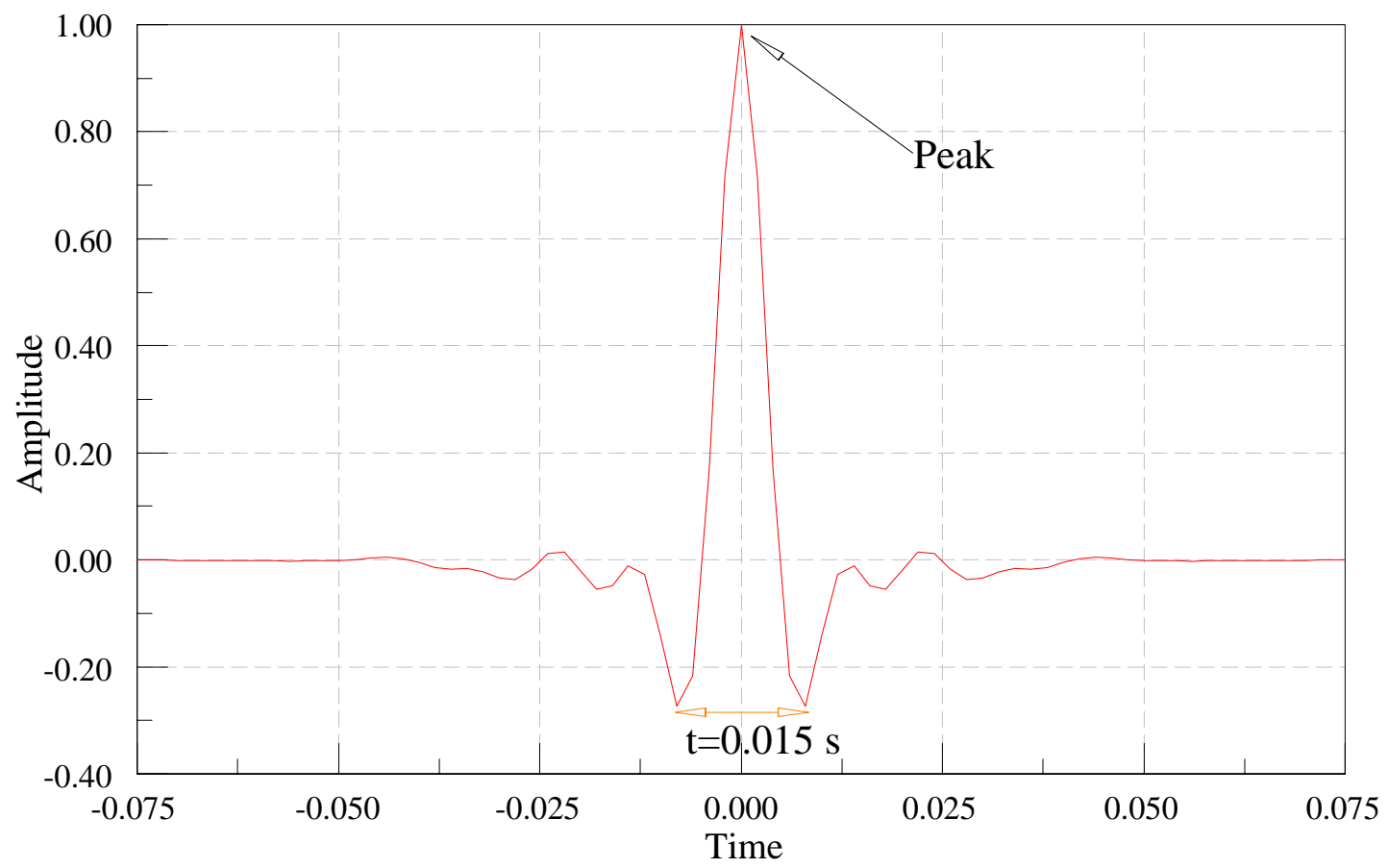

Figure 4.7: Wavelet extracted from the P-wave data

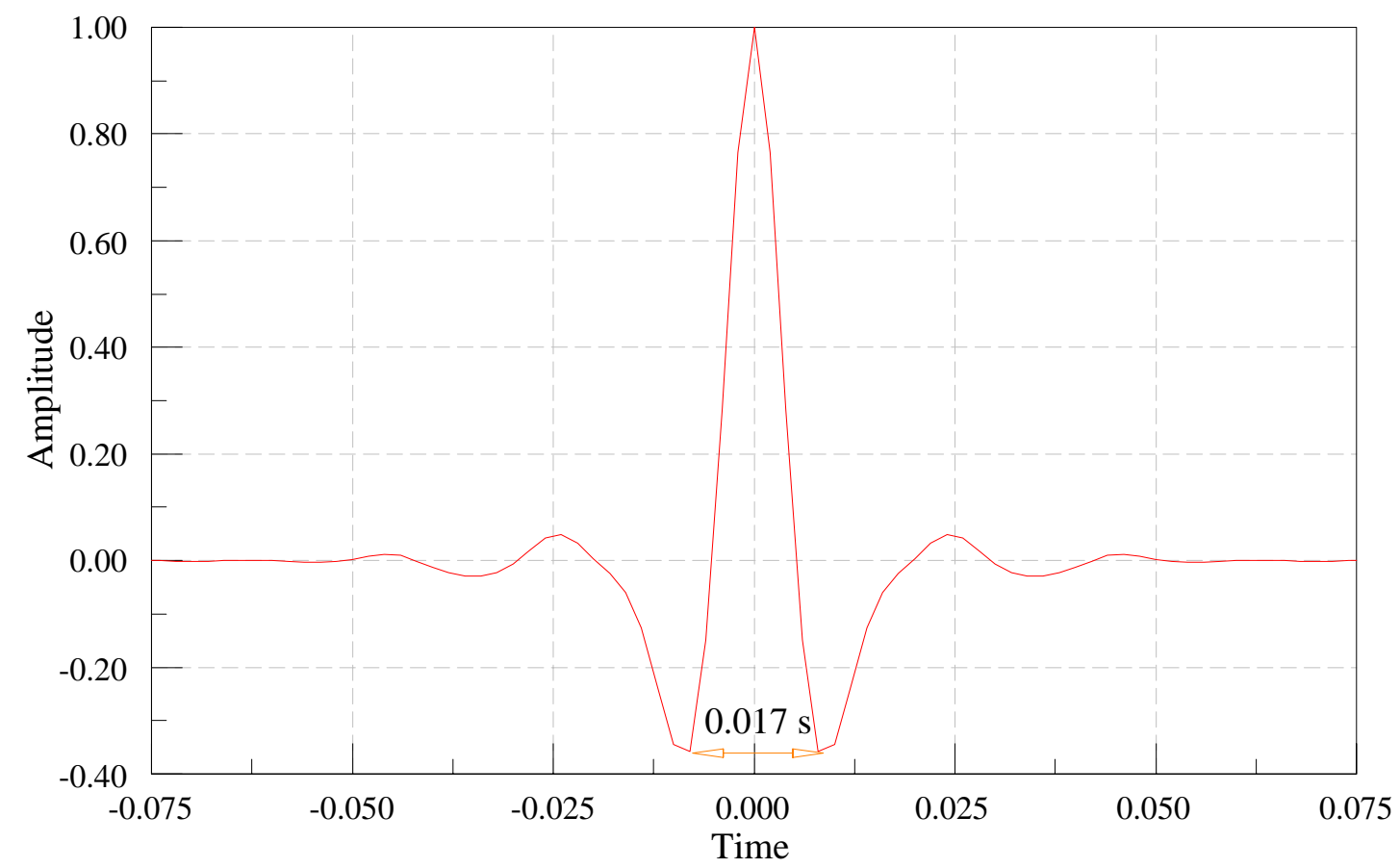

Figure 4.8: Wavelet extracted from the PS-wave data 


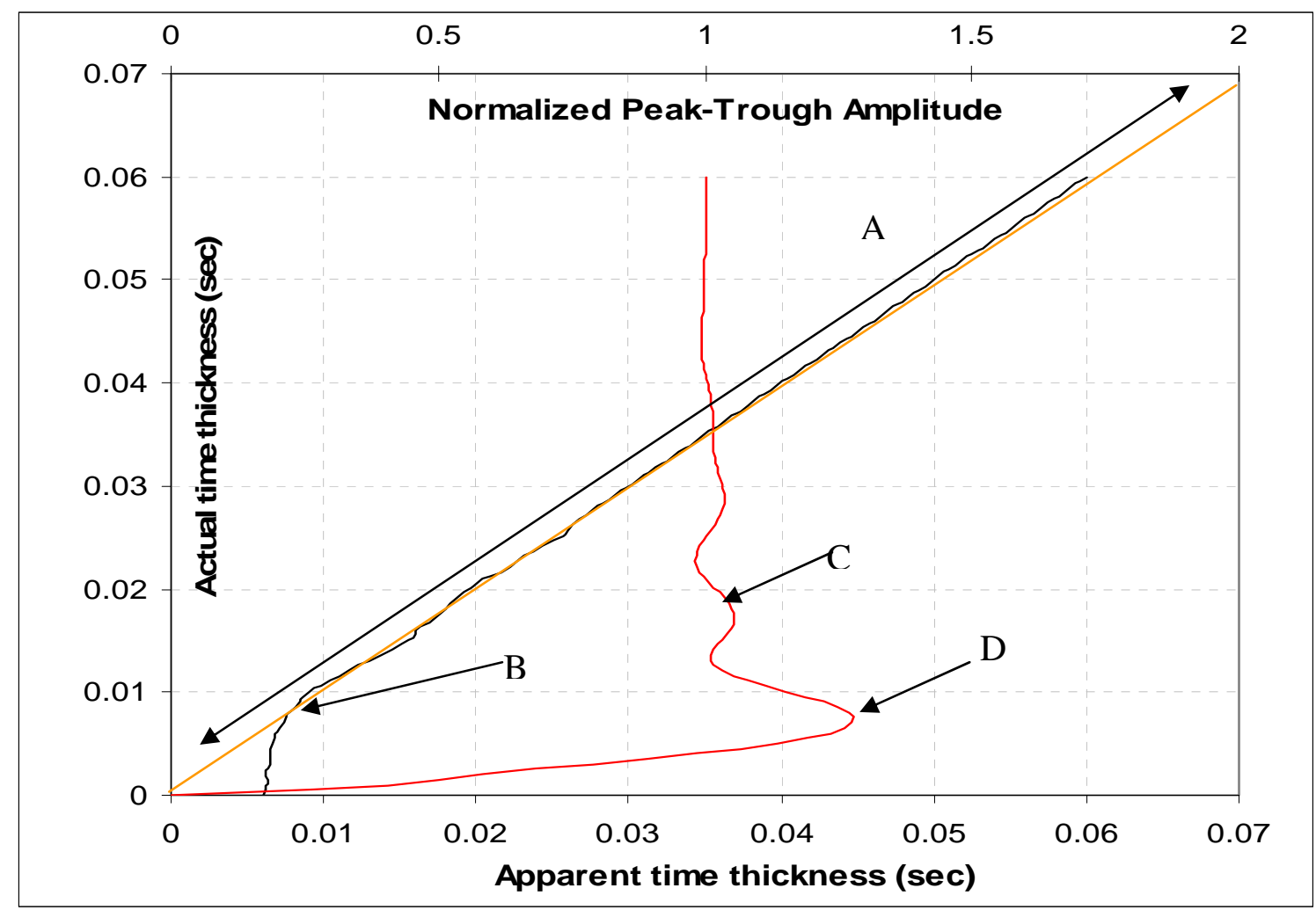

Figure 4.9: Resolution calibration curve for the P-wave wavelet. A: Ideal time resolution function, B: Point at which loss of time resolution occurs, C: Normalized peak-trough amplitude and D: Tuning amplitude. 
As the layer thins, reflections from the top and base of the layer start to overlap in time. Initially there is constructive interference between these two reflections. The peaktrough amplitude increases to a maximum at point $\mathrm{D}$, referred to as the tuning amplitude. The minimum time resolution measured on the $\mathrm{x}$-axis and the actual time at which tuning occurs, measured on the y-axis are approximately equal.

The dominant frequency is best estimated directly from the extracted seismic wavelet (e.g. figures 4.7 and 4.8). As noted earlier (Figure 4.2), the dominant frequency is the reciprocal of the time interval separating the side lobes on either side of the wavelet peak (figures 4.2 and 4.7). This time $\tau_{\mathrm{d}}$ is equal to $0.015 \mathrm{~s}$; thus the dominant frequency $\left(f_{d}\right)$ of the P-wave wavelet (Figure 4.7) is $66.66 \mathrm{~Hz}$. The two reflections begin to interfere with each other at a one-way time separation of approximately 0.04 seconds. The amplitude of the composite reflection reaches a maximum (the tuning amplitude) at a two way time of 0.007 seconds (Figure 4.10). The tuning time corresponds approximately to half the dominant period. The dominant frequency of $66.66 \mathrm{~Hz}$ is obtained from the reciprocal of twice the tuning time. This also corresponds to the time separation between the side lobes of the extracted wavelet (i.e. 0.015 seconds as shown in Figure 4.7).

Using an interval velocity of $15860 \mathrm{ft} / \mathrm{s}$ for the Morrow channel sand, the resolvable limit is calculated to be $59.5 \mathrm{ft}$. Similarly, using interval velocity of $16235 \mathrm{ft} / \mathrm{s}$ the resolvable limit for the Atoka Formation was calculated to be $60.8 \mathrm{ft}$.

Calibration curves were also constructed for the PS-wave data for the same time and trace window (Figure 4.10). The amplitude of the composite reflection reached a maximum at two-way time 0.00895 seconds (i.e. the two-way tuning time). The dominant frequency of $58.7 \mathrm{~Hz}$ was obtained from the time period separating the side lobes of the 


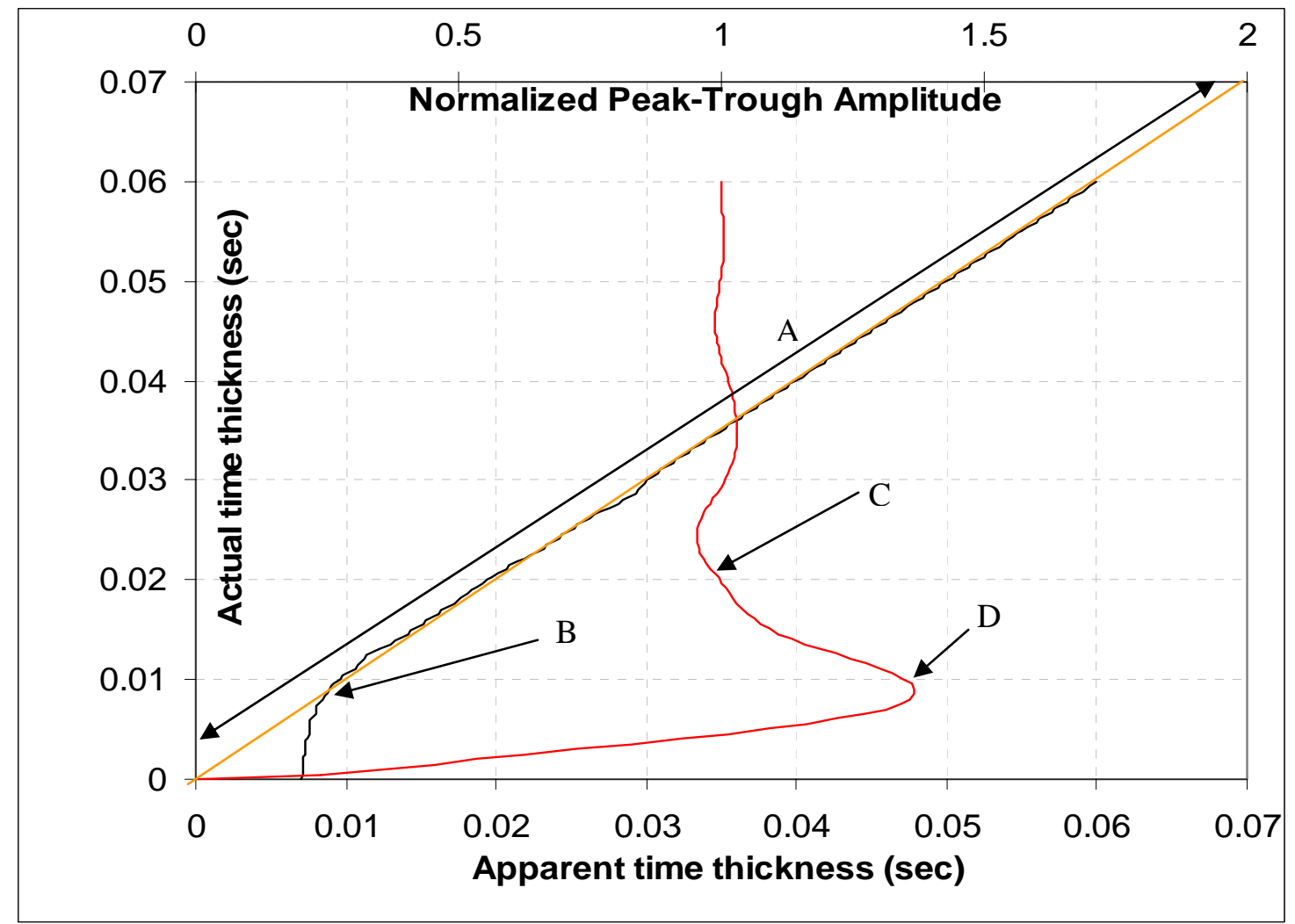

Figure 4.10: Resolution calibration curve for the PS-wave wavelet. A: Ideal time resolution function, B: Point at which loss of time resolution occurs, C: Normalized peaktrough amplitude and D: Tuning amplitude. 
extracted wavelet (Figure 4.6b). Using interval velocity of $16235 \mathrm{ft} / \mathrm{s}$ and $15860 \mathrm{ft} / \mathrm{s}$ for the Atoka and Morrow sand, the tuning thickness was determined to be $68.9 \mathrm{ft}$ and $67.4 \mathrm{ft}$ respectively.

The velocity for the PS-wave data is considered to be the same as that of the Pwave data since travel times in the available PS-wave volume have been corrected equivalent to P-wave travel times. A discussion of $\mathrm{V}_{\mathrm{p}}-\mathrm{V}_{\mathrm{s}}$ relationship is presented in Chapter 6. $\mathrm{V}_{\mathrm{p}} / \mathrm{V}_{\mathrm{s}}$ ratios observed in the lower Pennsylvanian range from approximately 1.6 to 1.9. Actual shear wave times $\left(T_{s}\right)$ vary as $\left(V p / V_{s}\right) T_{p}$ where $T_{p}$ is the P-wave travel time. The P-wave travel time would vary as $\frac{T_{p}}{2}\left(1+\frac{V_{p}}{V_{s}}\right)$. Because travel times in the PSwave volume have been compressed, this also has the effect of increasing the apparent frequency content. However, as shown in Figure 4.4, the bandwidth of the PS-wave data is significantly less than that of the P-wave data which leads to an increase in the minimum resolvable thickness.

As shown, resolution estimates can be made in various ways. Calculation based on the peak frequency yielded a resolution limit of $84.36 \mathrm{ft}$ for the Morrow Channel sand using P-wave data. Use of the Calibration curves on the other hand indicates that resolution of $59.5 \mathrm{ft}$ thick sands is possible. The peak frequency in a spectrum is not equivalent to the dominant frequency in most cases. An accurate estimate of the dominant frequency is the reciprocal of the time separation between side lobes adjacent to the wavelet peak.

The larger bandwidth of the P-wave data $(63 \mathrm{~Hz})$ produces a wavelet with much shorter dominant period than that associated with the PS-wave data which has only a 27 $\mathrm{Hz}$ bandwidth. Estimate of the horizontal resolution limit (the Fresnel zone radius) are 
tabulated in table 4.2. The computations were made using the average rms velocity available from the well velocity survey for the Lula 3 well. The dominant frequency was obtained from the extracted wavelet (Figure 4.8 and 4.10). The results show that the Fresnel zone radius of the P-wave data is slightly smaller, by approximately $68 \mathrm{ft}$, than that for the PS-wave data. At the depth of the Atoka-Morrow intervals, $R_{f}$ is approximately 1000 feet. This implies that reflection events from these intervals are affected by the acoustic properties of roughly circular regions with a radius of approximately $1000 \mathrm{ft}$.

\begin{tabular}{|c|c|c|c|c|c|}
\hline \multicolumn{6}{|c|}{ Horizontal Resolution } \\
\hline Data type & Interval & $\begin{array}{l}\text { Dominant frequency } \\
(\mathrm{Hz})\end{array}$ & $\begin{array}{l}\text { RMS velocity } \\
\text { (ft/s) }\end{array}$ & Depth (ft) & $\begin{array}{l}\text { Fresnel Zone } \\
\text { Radius (ft) }\end{array}$ \\
\hline \multirow{2}{*}{ P-wave } & Atoka & 66.66 & 16742 & 8403 & 1045.58 \\
\hline & Morrow & 66.66 & 16727 & 8540 & 1054.15 \\
\hline \multirow{2}{*}{ PS-wave } & Atoka & 58.82 & 16742 & 8403 & 1113 \\
\hline & Morrow & 58.82 & 16727 & 8540 & 1122.2 \\
\hline
\end{tabular}

Table 4.2: Horizontal Resolution limit calculated for the P-wave and PS-wave data.

Sanchez (2004) used a peak frequency derived from the amplitude spectrum to estimate the resolution limits of the Atoka-Morrow interval. He obtained a peak frequency of $45 \mathrm{~Hz}$ and estimated the tuning thickness for the Atoka-Morrow interval to be between $83-88 \mathrm{ft}$ for the P-wave data. As shown above, this overestimates the minimum resolvable thickness. Use of Calibration curve yields minimum resolvable thickness of between 59.5-60.7 ft. The results of Sanchez (2004) are similar to those presented above in Table 4.1. Use of the dominant frequency rather than peak frequency yields a smaller resolvable limit. Analysis of calibration curves also incorporates the influence of wavelet shape and phase on the resolution limit. In general, the analyses of calibration curve provide the most reliable estimates of the resolution limit. 
Comparison of the P-wave and PS-wave data reveals that the P-wave data can resolve intervals that are only 60 feet thick whereas intervals of about 70 foot thickness in the PS-wave data. This corresponds to an $10 \%$ increase in P-wave resolution limit relative to the PS-wave limit.

The minimum resolvable thickness of the Morrow sands is about $60 \mathrm{ft}$ in the Pwave data. Given that the Morrow channel sands have thickness of from 5-30 ft, it is clear that the top and base of the channel will not be clearly resolvable in P or PS-wave data. However, note that on the normalized amplitude plot (red curve in Figure 3) the amplitude associated with this travel time will be nearly $40-50 \%$ of the peak amplitude. Thus, while the channel may not be resolvable, it may be detectable; it may have significant influence on the composite response of reflection events in the vicinity of the target horizon. Detectability depends on several factors including background noise levels, and the level of interference from nearby reflection events. The challenge of 3D interpretation in this area is to hunt down the subtle indicators for the presence of the Harris Channel in the seismic response. Evaluation of RMS amplitude and the average absolute value of reflection amplitude associated with the lower Morrow interval may reveal areas of high sand concentration (see Chapter 5 and 6 ). 


\section{CHAPTER 5}

\section{SEISMIC P-WAVE DATA INTERPRETATION}

\subsection{Introduction}

The 3D P-wave seismic volume interpreted in this study covers an area of 24 sq miles in the heart of the Buffalo Valley field. In this study 3D seismic interpretations were made of several intervals extending from the Permian age Glorietta to the Mississippian Chester Formation with emphasis placed on lower Pennsylvanian intervals. Interpreted reflection events extended from approximately 0.406 seconds (top of the Glorietta) to 1.082 seconds (top of the Chester). Major faults observed in the seismic data are interpreted and their history of motion is discussed.

Interpretation of the 3D seismic data volume yields travel time and isochron maps of reflecting horizons. Interpretations were restricted to fairly continuous and prominent reflection events observed in the data. These events are usually associated with reflections from stratigraphic boundaries (e.g. top of the Strawn or top of the Wolfcamp). Ideally, the map view of a reflecting horizon will reveal components of the depositional system such as channel morphology and its extent through an area. Such features may be uncovered by examining successive time slices through the 3D volume. Thin and localized stratigraphic units such as sand lenses or channels may not be observable as distinct reflective horizons but their cumulative effects may be observed in the time slice flattened to nearby horizons or in the properties of windows of data centered about the horizon. 
The first step in a seismic stratigraphic interpretation is to establish the relationship between the stratigraphy and corresponding reflection events in the seismic data volume. The relationship is established by tieing well log data to the seismic data. The tie between subsurface geology and seismic response at Buffalo Valley was established at the Lula 3 well. A successful tie between the synthetic and surface seismic was achieved by first making a tie to the near-offset VSP (Wilson and Pyakurel, 2005). Time shifts in the stacked seismic data introduced by processing led to difficulties in making a direct tie. Use of the well velocity survey and near-offset VSP helped identify the time shift between the processed surface and well-seismic travel times. The acoustic properties of subsurface strata, especially the Atoka-Morrow interval, detected by the sonic log are not typical of the larger (Fresnel zone scale) volume of rock being sampled by the surface and VSP waveforms. These Fresnel zone effects (see Chapter 4) also contributed to a less-than-perfect tie of the synthetic to the data.

Once a synthetic tie was obtained, formation tops interpreted from the well logs were correlated to seismic reflection events and then corresponding seismic horizons were picked. The Morrow interval is the primary target of interest and an interpreted topof-the Morrow reflection event was picked on every inline and crossline through the seismic data volume. This was necessary since the top of the Morrow is not associated with a single distinct reflection event. The top of the Atoka and Chester Formations were picked on every other inline and crossline, while top of the remaining (more continuous) horizons were picked every 5th inline and crossline. Reflection events within the lower Pennsylvanian Atoka-Morrow interval were generally discontinuous and difficult to pick. More coherent reflections above and below these intervals were used as a general guide 
for picking the Atoka-Morrow events and carrying them through the data. Kingdom Suite's auto-picking and smoothing algorithm was used to interpolate between hand picks and to smooth them. As discussed in Chapter 4, the individual sands in the lower Morrow are not seismically resolvable and they could not be picked as distinct reflection events. However, amplitude variations on the top-of-the-Morrow horizon may be indicative of channel sand distribution. Seismic amplitudes from this interval were investigated using several approaches provided in Kingdom Suites' volume attributes module. Attribute maps consisting of the root mean square (RMS), average absolute value (AAA), integrated amplitude, etc. were computed and evaluated for possible relationship to the Harris Channel and oil production trend discussed in Chapter 3.

\subsection{Structural Setting}

Seismic data reveal that the Buffalo Valley field is bounded to the east and west by the nearly vertical faults that drop to the east (figure 5.1 through 5.4). These faults produce mapable offsets in the lower Pennsylvanian strata. Continued movement along the faults produces monoclinal flexures in shallower overlying strata. In lower Pennsylvanian strata the western fault is continuous through the survey area while the eastern fault dies out to the north (Figure 5.3). A 3D view of the boundary faults is illustrated in the Figure 5.4.

The east and west boundary faults cut through the lower Mississippian and Pennsylvanian units, and terminate before reaching the top of the Permian Wolfcamp Formation. These faults were active during deposition of the Pennsylvanian units. Pennsylvanian strata thicken on downthrown fault blocks (figures 5.8 through 5.11 and 5.13). The throw across the western fault is more pronounced than that across the 




Figure5.1: East-west seismic section showing steep faults terminating in the lower Wolfcamp interval. The figure reveals that resolvable fault offsets do not extend beyond the lower Permian Wolfcamp reflection event.



Figure 5.2: East-west seismic section with steep vertical faults and flower structure and folding. The pattern of minor faulting and folding just to the west of the eastern border fault is suggestive of a flower structure. 

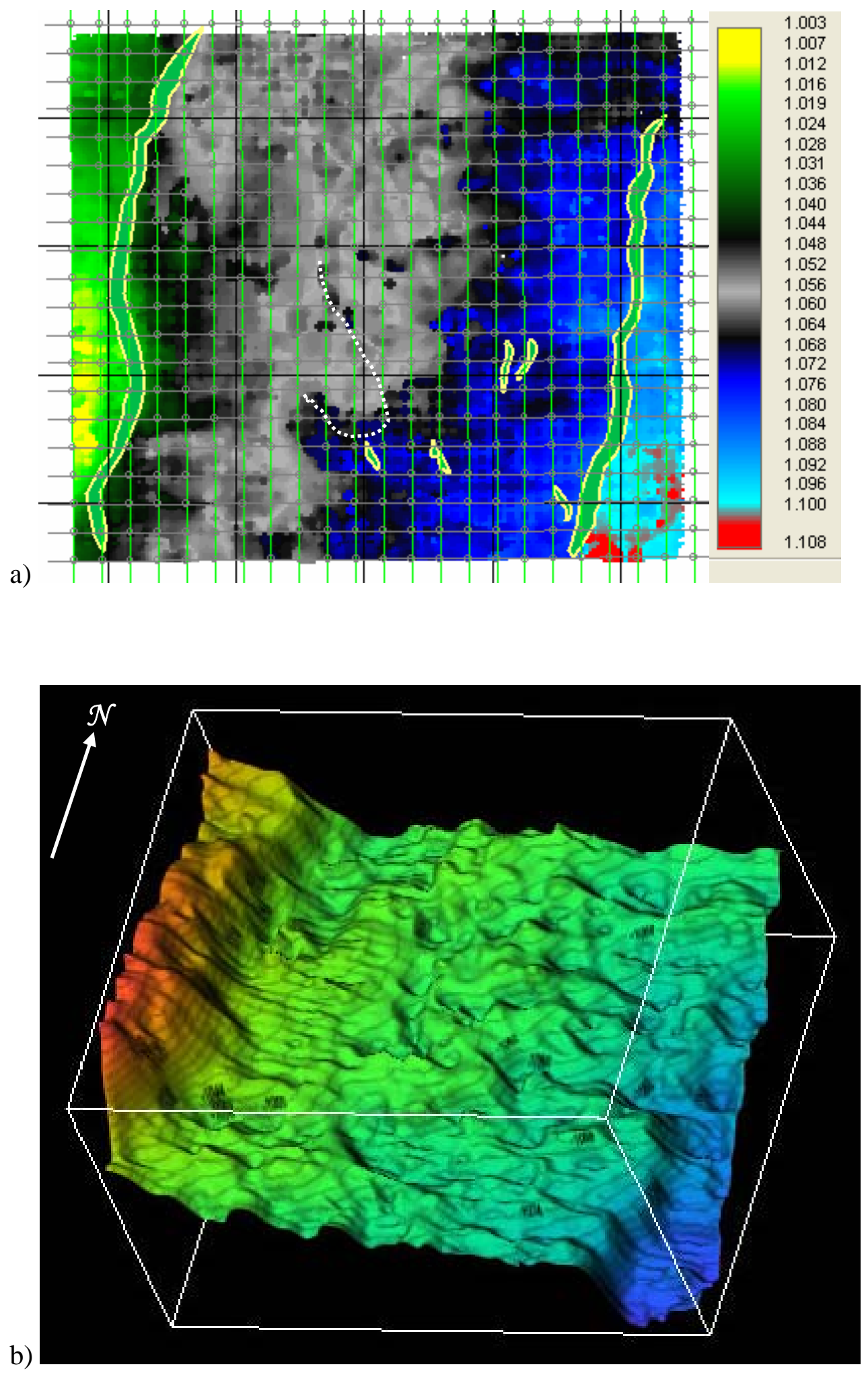

Figure 5.3: a) Time structure on the Chester reflection event. The dotted white line defined the location of an abrupt drop in structure within the central block; b) 3D perspective view of Chester reflection event. Vertical exaggeration is 1:100. 


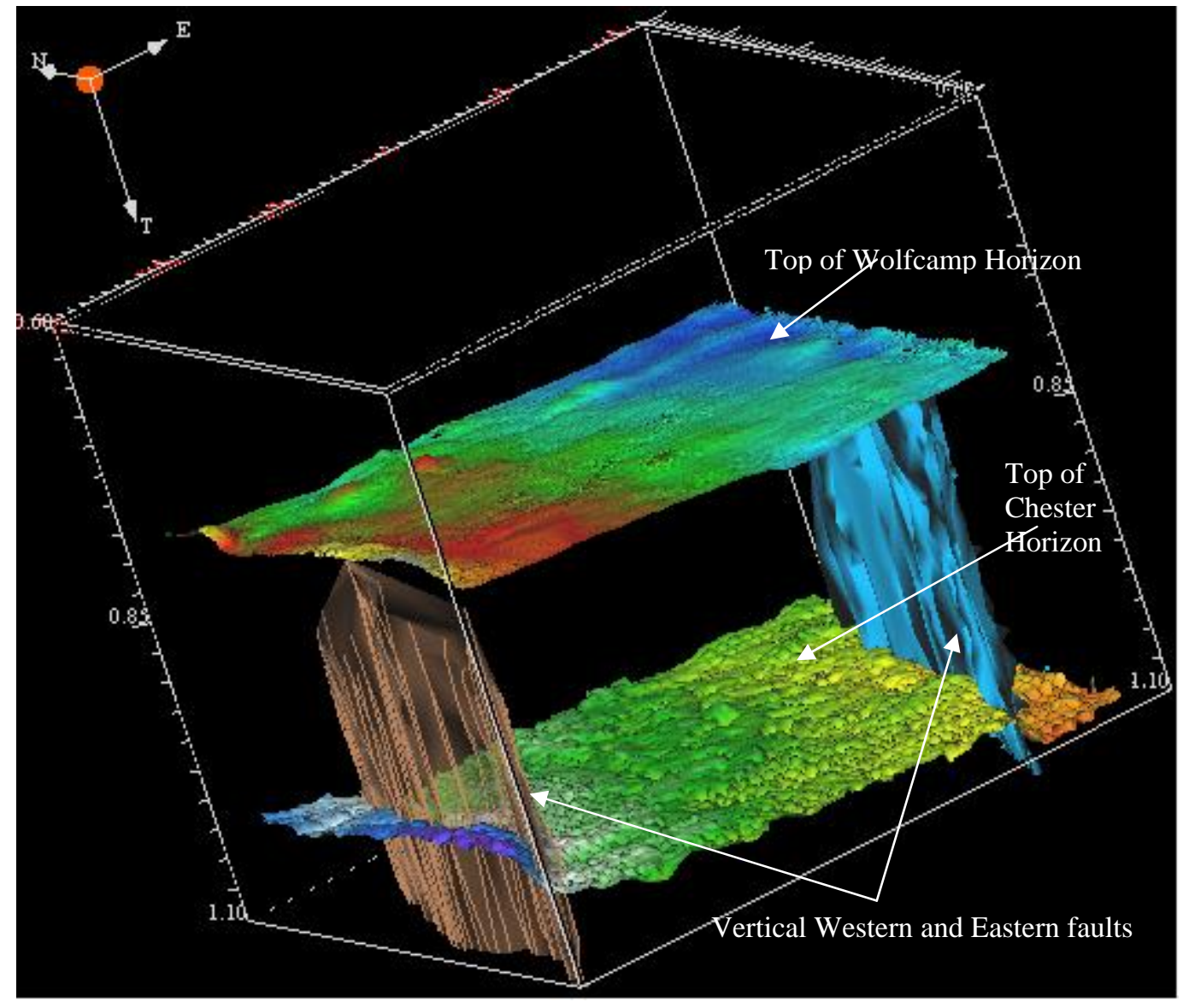

Figure 5.4 : 3D view of the western and eastern border faults in the Buffalo Valley field. Resolvable offsets in these faults do not extend above Wolfcamp reflection event. 
eastern fault. The steep nature of both faults makes it difficult to classify them as reverse, normal or strike slip.

Sanchez (2005) interpreted these faults as reverse faults. Indeed, the fault planes often dip steeply to the west suggesting reverse movement. However, plan view representations of the fault surfaces suggest that the fault planes do not dip uniformly to the west but oscillate from west dipping to east dipping along their length (Figure 5.5). These observations help establish that these faults are likely strike-slip in origin. A typical plan view of a strike slip fault system is illustrated in Figure 5.6. Strike slip faults are steep and often have dip reversals along their length that are reverse along the compressional bend and normal along the releasing bend. It may be possible that regional compression from southeast during the Ouachita-Marathon orogeny generated some small scale strike slip displacements along the Northwestern Shelf of the Delaware Basin.

In terms of the regional context, Hills (1984) described steeply dipping faults located the southeast of the study area bordering the eastern margin of the Delaware Basin. The faults noted by Hills have roughly north-south trend (Figure 5.7) and cut through lower Mississippian to the lower Wolfcamp strata. These faults were interpreted to have originated as reactivated left-lateral strike slip faults along preexisting Proterozoic lines of weakness. Numerous other steeply dipping faults of MississippianPennsylvanian age in the Delaware Basin have been interpreted as left-lateral strike slip faults (Shumaker, 1992). Similarity of faults in the study area to those noted by Hills (1970) and Shumaker (1992) (north-south trend offsets Mississippian to the lower Wolfcamp strata) suggests the faults in the Buffalo Valley field originated under similar stress regimes. 
a)

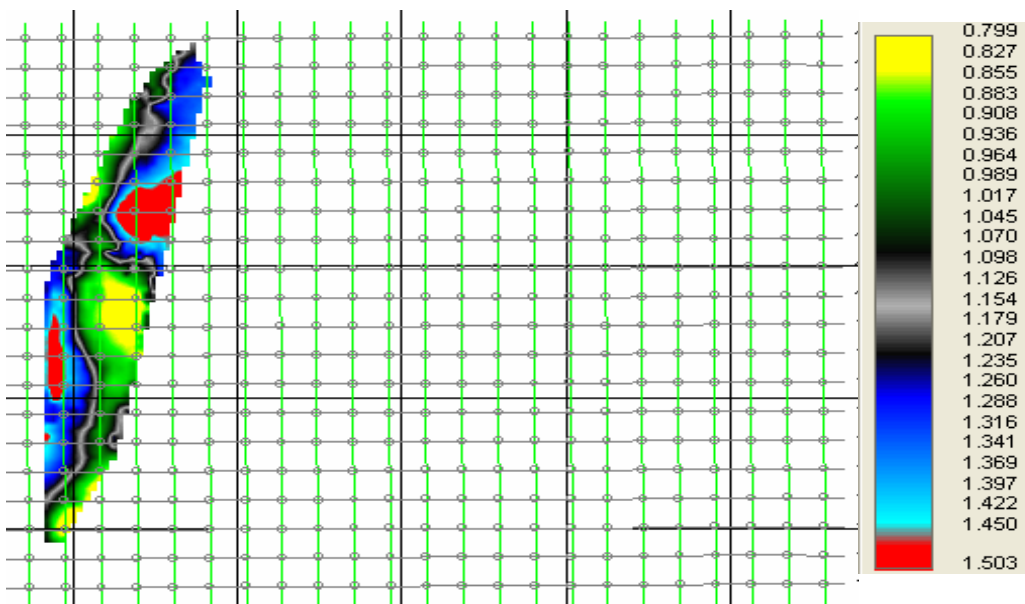

b)

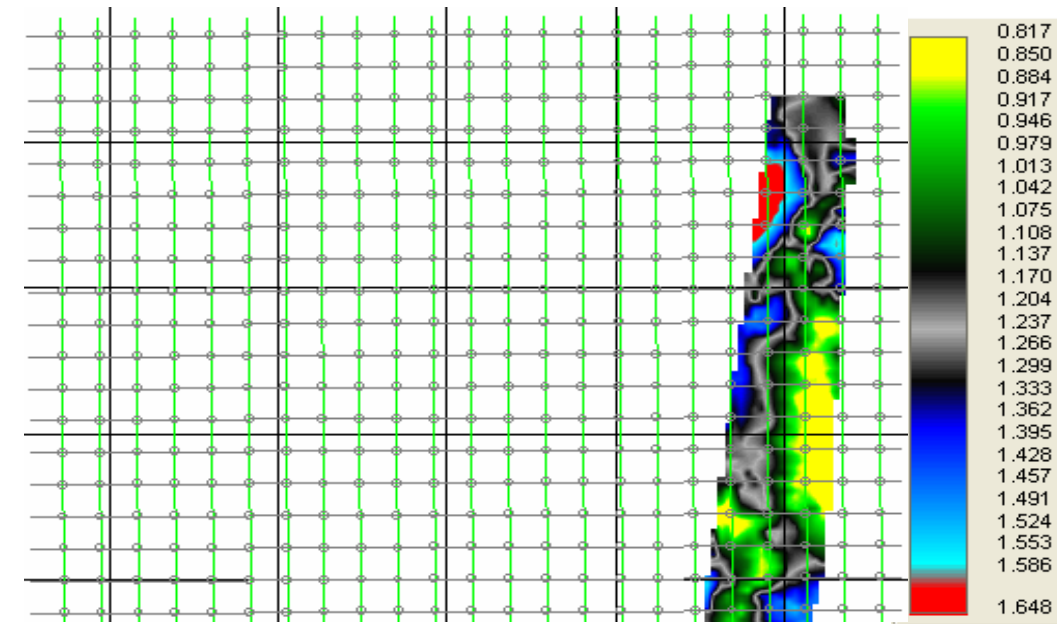

Figure 5.5: Time structure of the boundary faults. Both of these faults oscillate in dip from west dipping to the east dipping along their length; a) Western boundary fault b) Eastern boundary fault

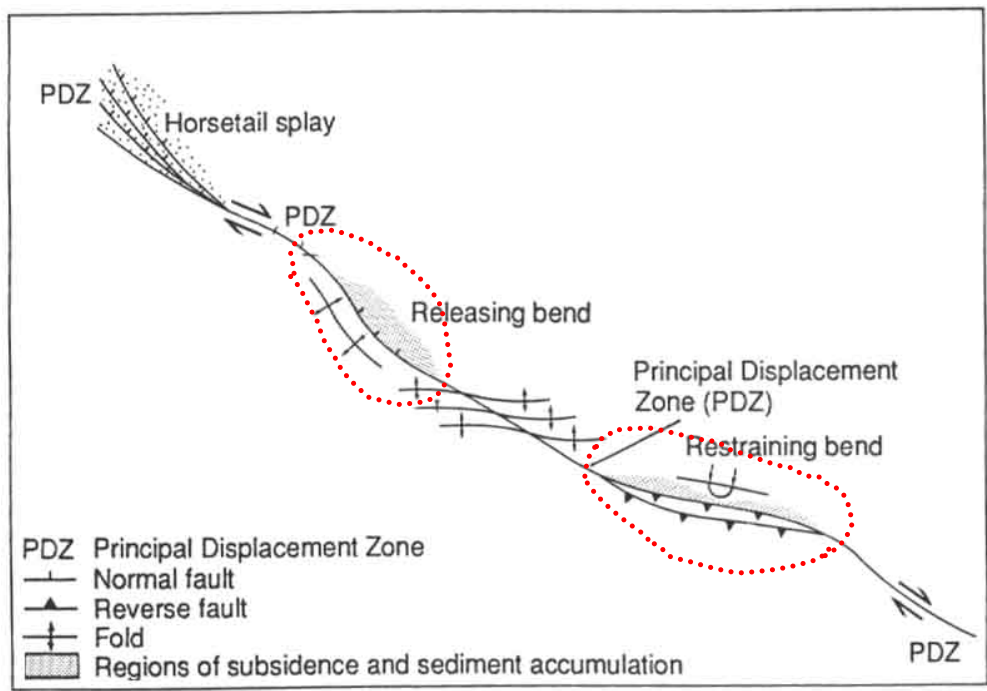

Figure 5.6: Plan view of a typical strike slip fault showing dip reversals. (Modified after Allen and Allen, 1990). 


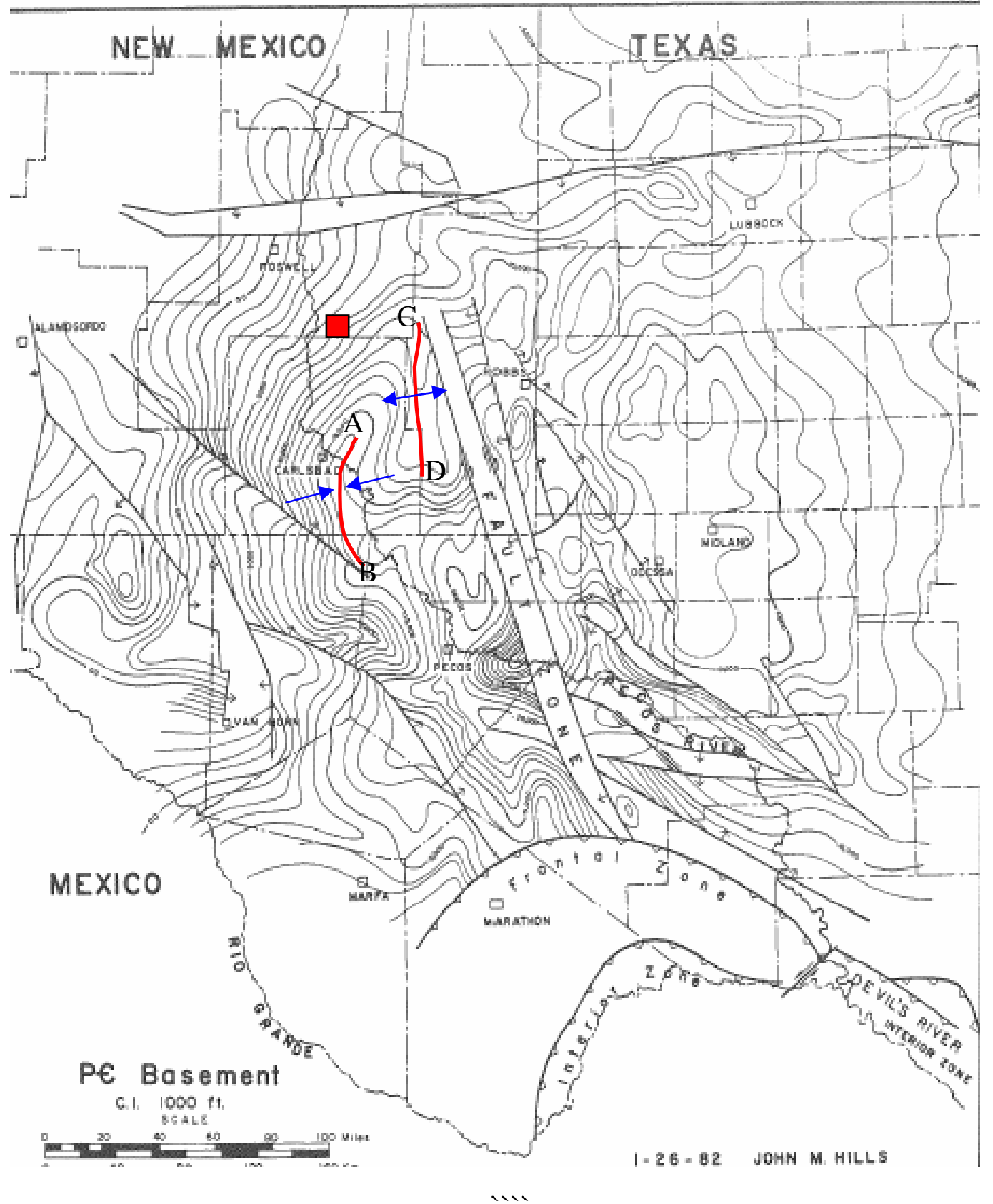

Figure5.7: Precambrian north-south trending basement fault zone. The contours represent subsea elevation on the Precambrian basement surface at $1000 \mathrm{ft}$ contour interval. The location of the Buffalo Valley field is highlighted by the red square. Line AB is a structural low; CD is a structural high. Modified after Hills (1970). 
Regional transpression and compression continued throughout the Pennsylvanian and ended during the early Permian (Hills and Galley, 1988). Minor local movements continued through the late Wolfcampian. Casavant (1999) suggested that basement faulting in the region is the rule rather than the exception since the orientation of the Phanerozoic structural elements matches well with the Precambrian structural fabric. Pennsylvanian faults in the region are generally associated with fault reactivation of preexisting Proterozoic lines of weakness (Hills, 1984).

There are two schools of thought concerning the reactivation of the older basement faults in the Permian Basin region by the Marathon-Ouachita orogeny. One theory suggests that reactivation occurred in the form of wrench faulting which obscured earlier Precambrian normal and reverse faults (Galley, 1968; Bowsher, 1991; in Casavant 1999). The other theory suggests that fault reactivation occurred in response to moderate to gently dipping basement-involved overthrusts (Ye et al., 1996; in Casavant 1999). The boundary fault geometry in the Buffalo Valley field supports the wrench fault interpretations suggested by Galley (1968) and Bowsher(1991). 


\subsection{Seismic Horizon interpretation}

\subsubsection{Mississippian Chester Horizon}

The Chester reflection event (figures 5.1 and 5.3) is a complexly faulted horizon. Noticeable offsets occur across the eastern and western boundary faults discussed earlier. The presence of additional minor faults is also suggested by interruptions of reflection patterns (Figure 5.3). The reflection from the top of the Chester horizon extends from 1.003 to 1.108 seconds. The time structure map (Figure 5.3) of the Chester reveals an approximate strike of $\mathrm{N} 15^{\circ} \mathrm{E}$; the dip is to the southeast. Structural relief across the Chester is concentrated across the bounding faults on the east and west margins of the survey. An abrupt drop in structure occurs along a north-south trend through the center of the block. This drop is indented to the west in the southern part of the area (Figure 5.3). In some places, the Chester Limestone horizon is characterized by weak reflection amplitude and polarity reversal (Figure 5.1). These character changes may be associated with variations in carbonate cement content in the Morrow clastics and associated impedance contrasts. In addition, log responses reveal the presence of considerable heterogeneity in the lower Pennsylvanian strata. These, along with tuning effects in thinned intervals contribute to poor reflection continuity.

\subsubsection{Morrow interval}

The time structure on top of the Morrow Formation reveals similar N15 ${ }^{\circ} \mathrm{E}$ strike of the Chester Formation and southeast dip (Figure 5.8). This northeast strike roughly correlates with the general northeast trend of the Northwest Shelf. The upper Morrow 

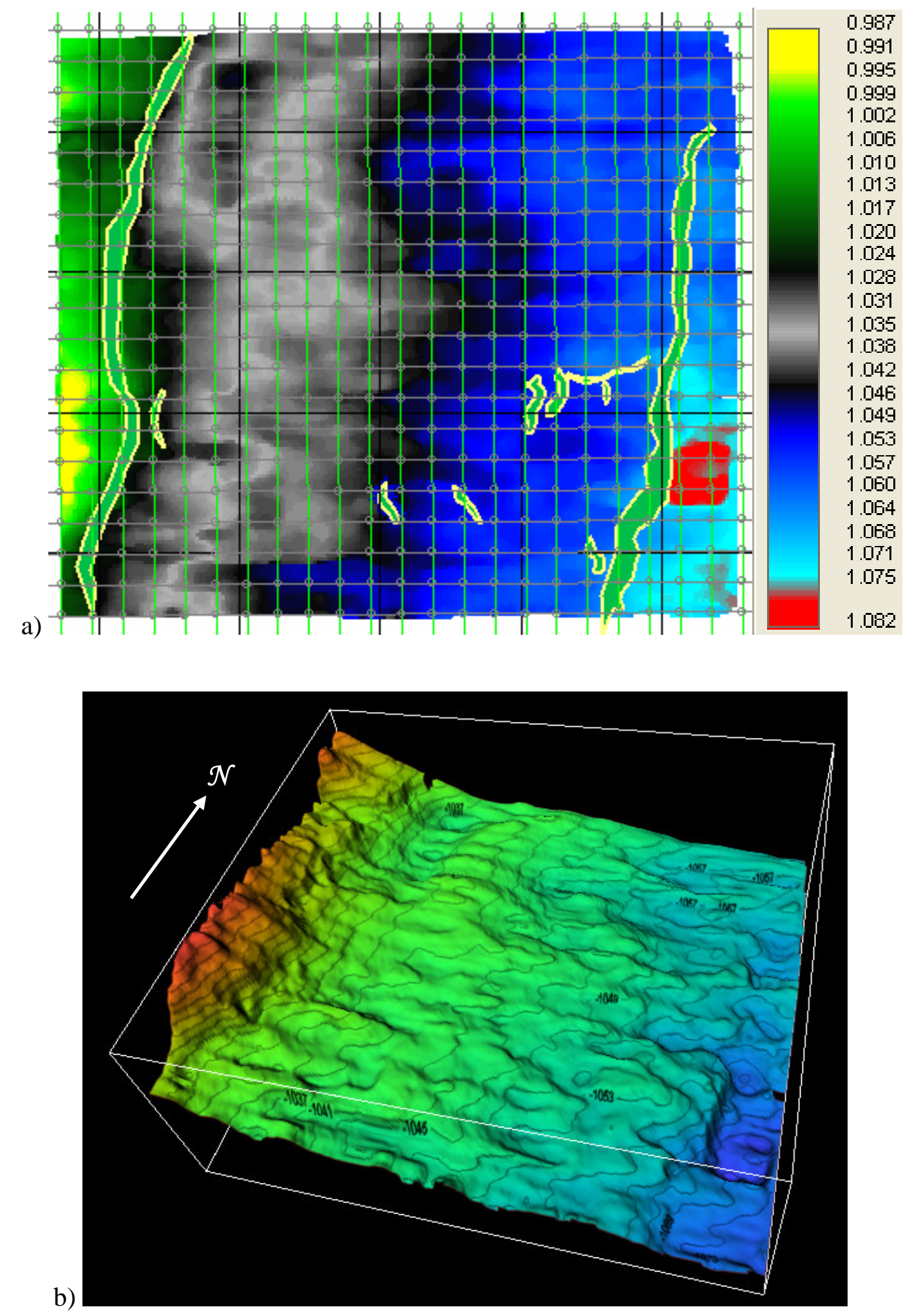

Figure 5.8: a) Time structure on the Morrow reflection event, b) 3D perspectives view of Morrow time-structure. (1:100 vertical exaggeration) 
limestone has strong acoustic impedance contrast (black cycle in Figure 5.1 and 5.2) with the overlying shale of the lower Atoka interval. The positive amplitude of the reflector is associated with an increase in density from 2.35 to $2.65 \mathrm{gm} / \mathrm{cc}$ and velocity from $15500 \mathrm{ft} / \mathrm{s}$ to $16650 \mathrm{ft} / \mathrm{s}$. However, in places the amplitude decreases to zero and becomes negative, revealing significant lateral discontinuity and heterogeneity in the fluvial-deltaic sediments which comprise the Morrow.

Two way travel time to the Morrow reflection event ranges from 0.987s to 1.082s. The time structure map of the Morrow event reveals distinct displacement across the eastern and western boundary faults (Figure 5.8). The structural high is located to the west; the structural low, to the southeast. The Morrow tends to be more steeply dipping to the southeast. Structural relief is largely controlled by the boundary faults. Some minor faults near the eastern boundary fault (Figure 5.1) also produce moderate structural relief.

The isopach of the Morrow Formation (including the Barnett Shale) (Figure 5.9), top of Morrow to top of Chester - was computed using an average interval velocity of $16250 \mathrm{ft} / \mathrm{s}$. The isopach reveals considerable variability in thickness: thickness ranges from a maximum of $295 \mathrm{ft}$ to a minimum of $55 \mathrm{ft}$. A zone of thickening with northeastsouthwest trend of the paleo shoreline occurs in the southern part of the survey area; another belt of thick sediments runs northwest-southeast through the central-northern part of the survey area (Figure 5.9a). Thickened Morrow intervals may roughly define areas of increased channel sand accumulations. Variable thickness distribution suggests the influence of a meandering channel system with a variable trend. It is also possible that thickening in the north-central part of the survey area is associated with a fluvial channel system while the thickened interval to the southeast may represent a shoreline system. 


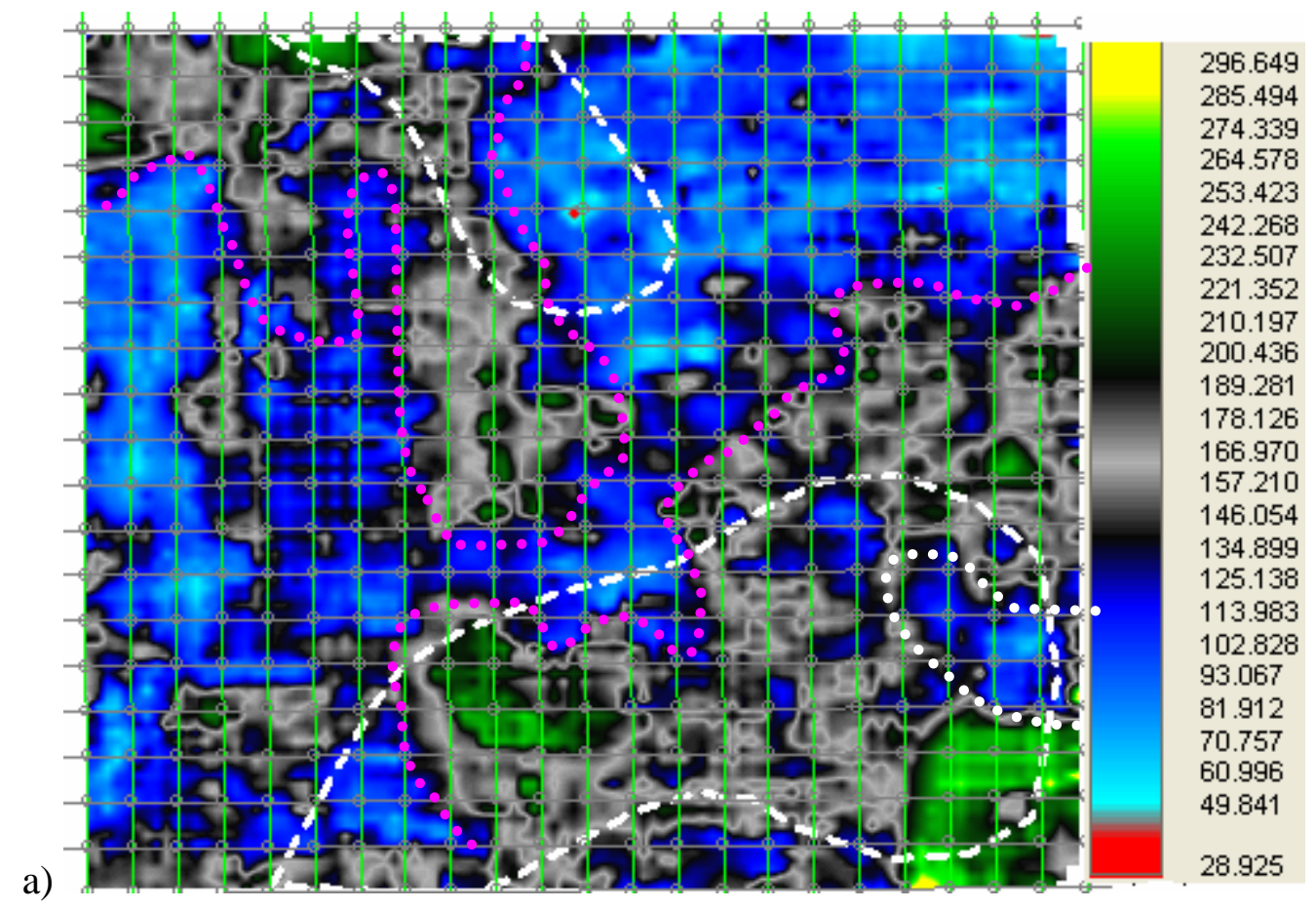

b)

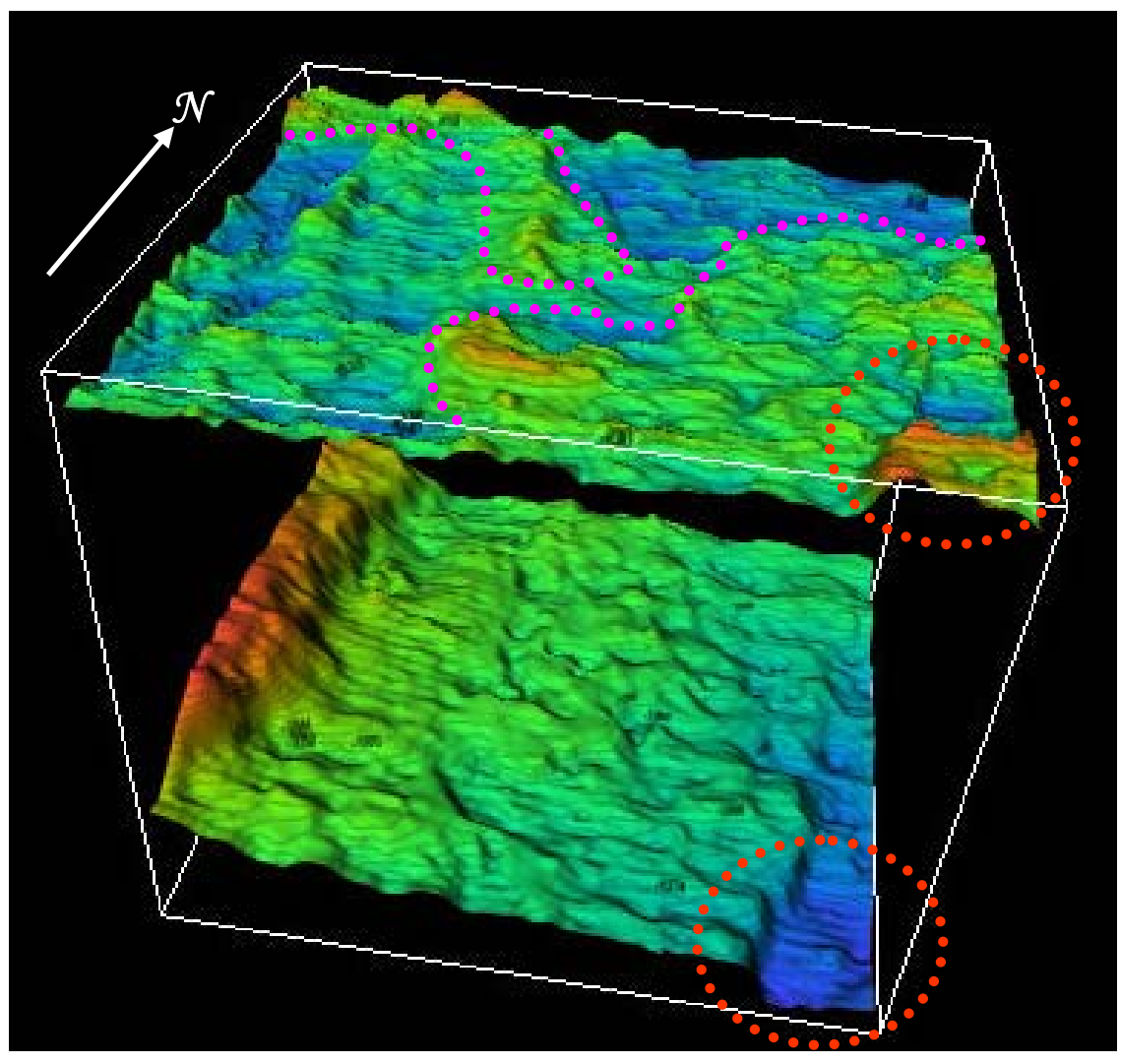

Figure 5.9: Isopach of the top of the Morrow-to- top of the Chester limestone; b) Isopach of the Morrow overlaid on top of the Chester time structure. Thickening in the southeast corner of the survey area is associated with syndepositional movement along the eastern border fault. The purple dotted line outlines areas with thickened section. 
Comparison of the Morrow isopach with the Chester time structure (Figure 5.9) reveals noticeable thickening in the southeast corner of the survey area. Thickening occurs abruptly across the fault but is restricted to a small area. This thickening across the fault suggests the fault was active during deposition of the Morrow interval. However, the westernmost fault block appears to be fragmented into smaller blocks that moved independently of each other. A polygon of Barnett Shale thinning is overlaid on the isopach of the Morrow interval (Figure 5.10). Although thinner Barnett Shale zones generally lie under the thickened Morrow section, thinning is not restricted to thickened Morrow areas (Figure 5.10). This suggests that thickening of the Morrow is not in general related solely to channel sand accumulation.

\subsubsection{Atoka Interval}

Two-way travel times to the top of the Atoka Formation extend from $0.977 \mathrm{~s}$ to $1.061 \mathrm{~s}$ (an 88 milliseconds interval). A negative impedance contrast across the top of the Atoka is associated with an abrupt boundary separating carbonates in the Strawn from shales in the Atoka. This high amplitude event (Figure 5.1) is fairly coherent throughout the 3D survey.

The time structure on top of the Atoka Formation has an approximate $\mathrm{N} 15^{\circ} \mathrm{E}$ trend with southeast dip (Figure 5.11). The structural relief is largely controlled by the eastern and western boundary faults. Compared to the Morrow time structure, the Atoka has moderate relief and is structurally less complicated between the boundary faults. 


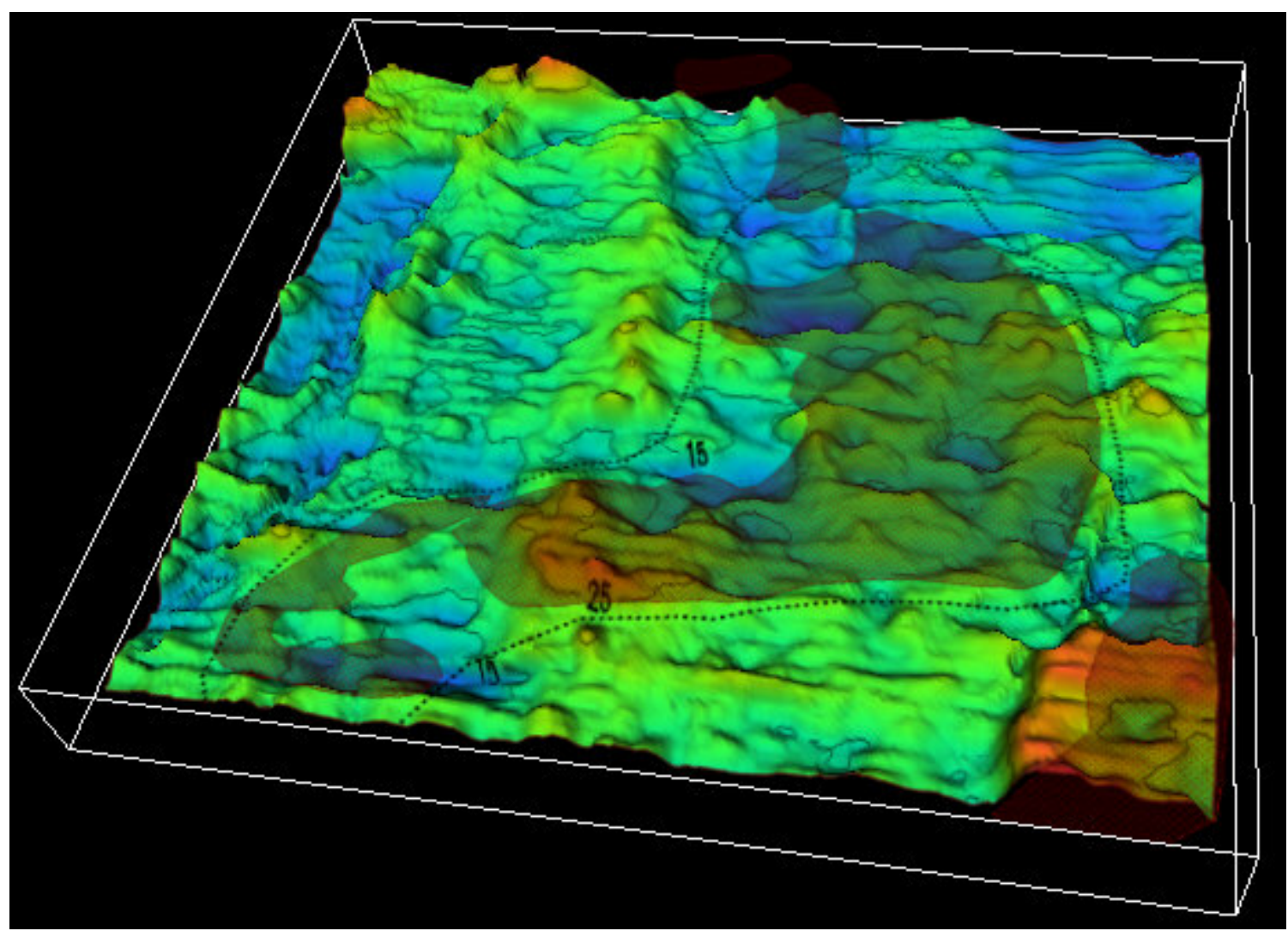

Figure 5.10 : Vector overlay of Barnett shale thinning zone over the isopach of the Morrow interval. The shaded region represents thinner Barnett Shale zones. 

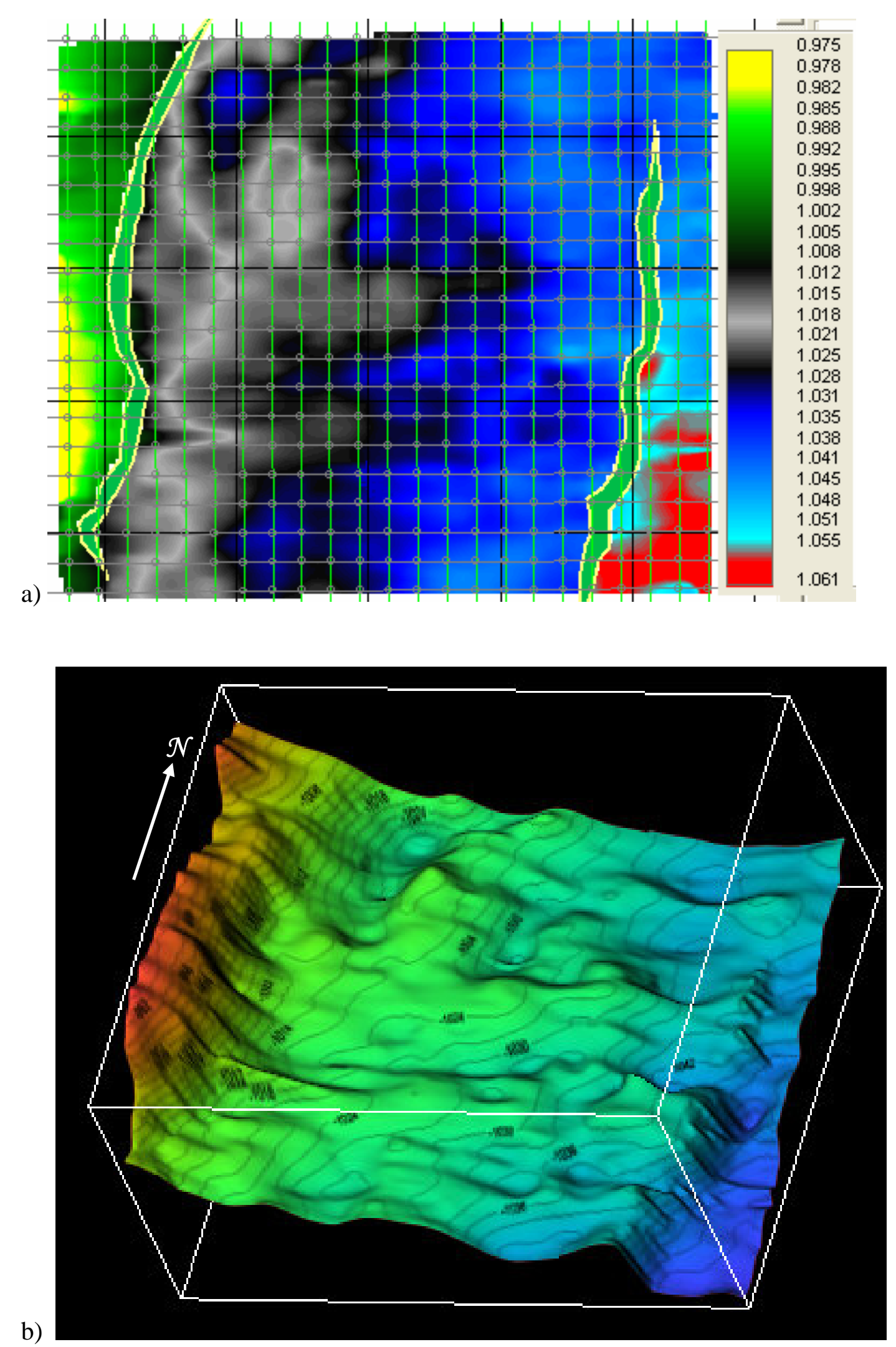

Figure 5.11: a) Time structure on the Atoka reflection event; b) 3D perspective view of Atoka reflection event. Vertical exaggeration is 1:100 
The Atoka isopach (Figure 5.12) reveals a belt of thickening west of the western boundary fault. This suggests that the western block dropped down to the west during deposition of the Atoka. The interval thickens gradually across the central block, but there is some evidence especially in the perspective view that thickening and thinning along the eastern margin of the field occurs over the eastern boundary fault. The block that moved down during the deposition of the Morrow, rose during deposition of the Atoka and thinned the interval in the southeast corner.

Overall, the central block appears to have rotated down to the east into the Delaware Basin during deposition, while the western block dropped to the west. The drop of the western block to the west represents an inversion of earlier movements during deposition of the Morrow.

The isopach of the entire Atoka-Morrow interval overlaid upon the Chester structure map provides an overview of syndepositional block movements during the lower Pennsylvanian (Figure 5.13). Pronounced thickening occurs to the southeast with more abrupt thickening in the southeast corner across the eastern boundary fault. Overall, the up and down movements on the western boundary fault did not yield noticeable thickening trend on the interval as a whole. 

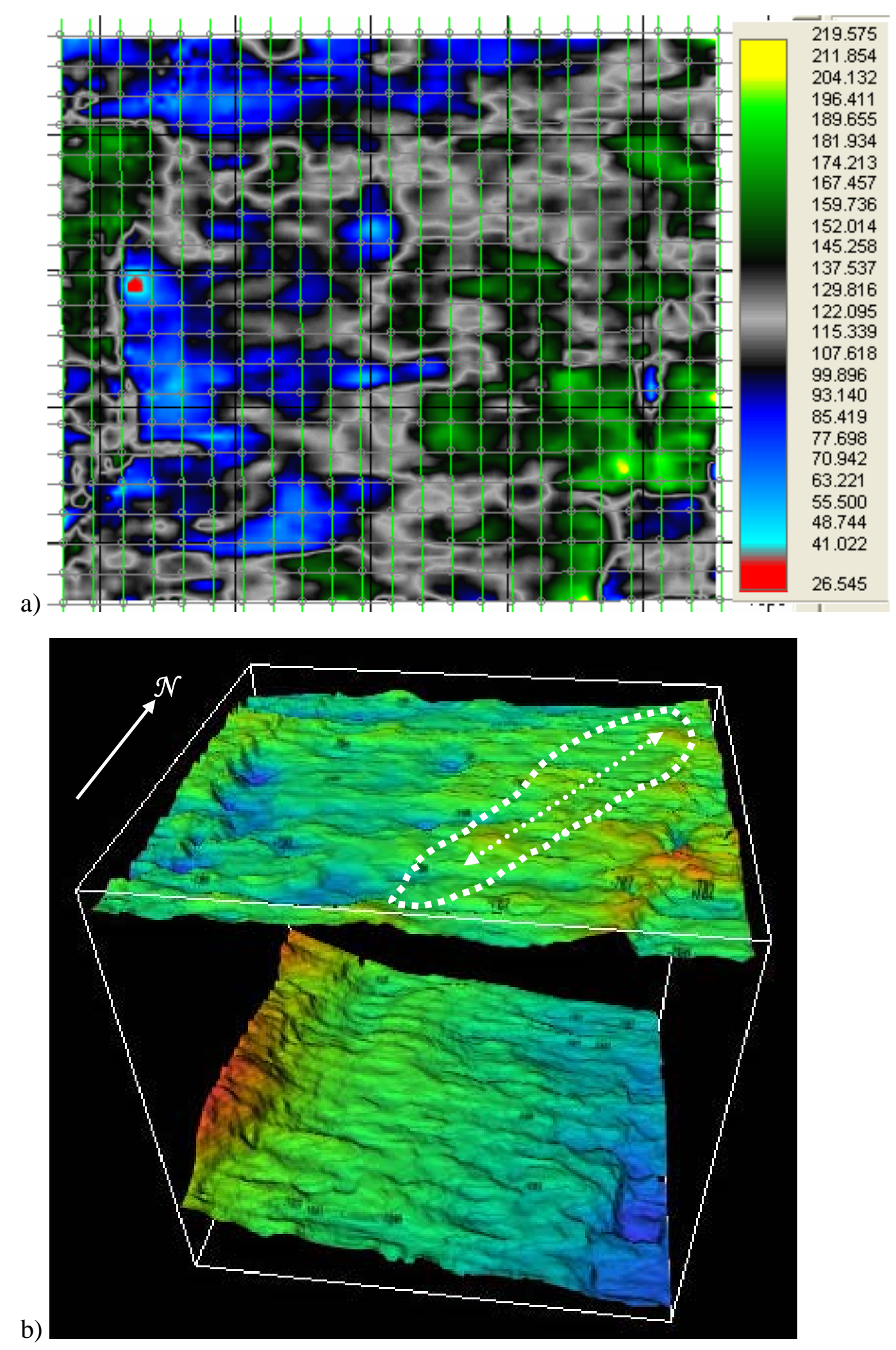

Figure 5.12 : a) Isopach of the Atoka-to-Morrow-top interval; b) Isopach of the AtokaMorrow interval overlaid on top of the Morrow time structure. 

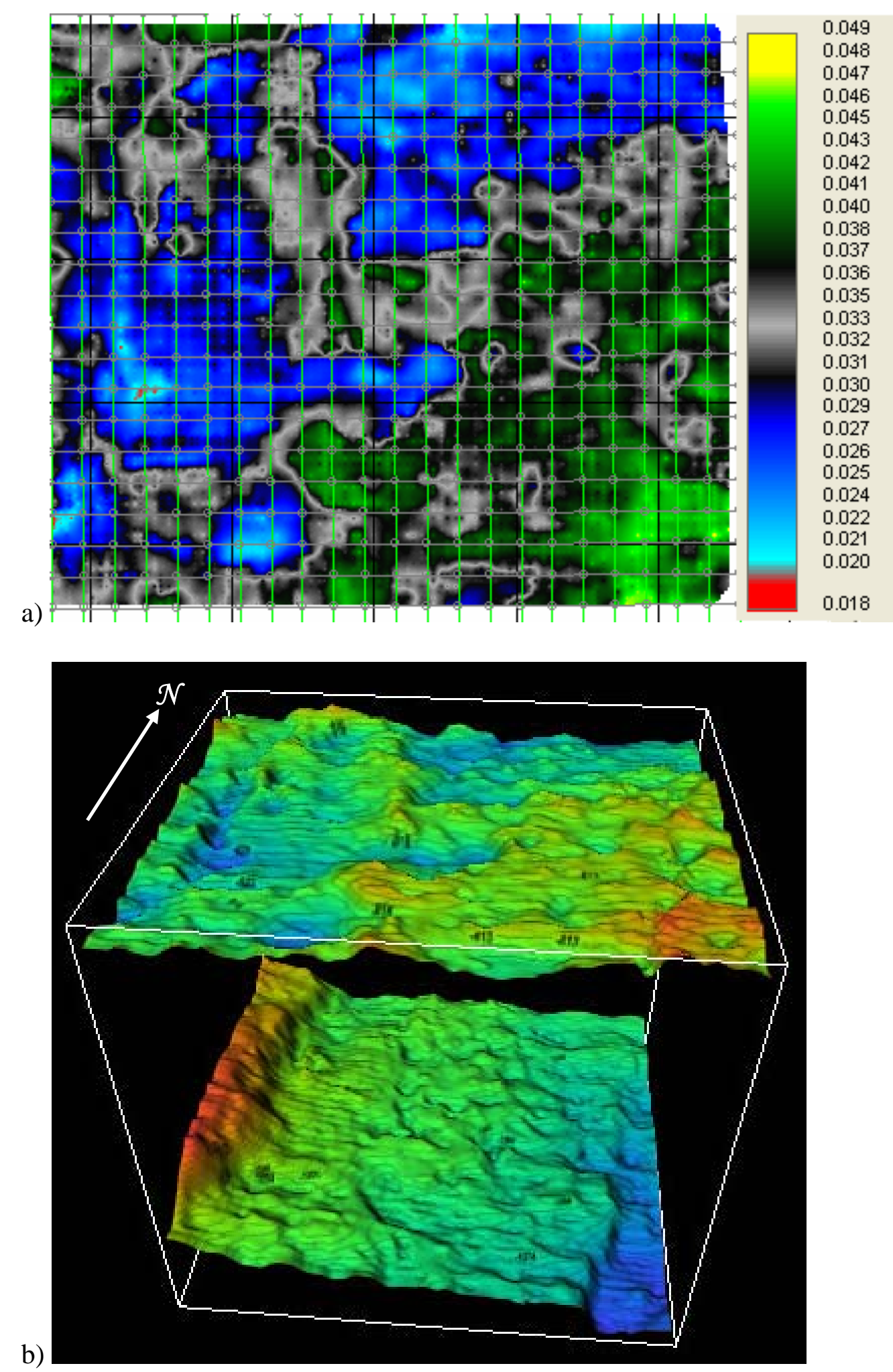

Figure 5.13: a) Isochron of the Atoka-Chester interval; b) Atoka-Chester isochorn overlaid on the Chester time structure. 


\subsubsection{Cisco Interval (Upper Pennsylvanian)}

The time structure on top of the Cisco is similar to that of underlying reflections. Time structure on the Cisco has variable strike through the survey area. Across the central block the structure strikes northwest and drops to the northeast. Structures on the western and eastern block strike roughly to the north (Figure 5.14).

The Cisco to Atoka isochron map shows pronounced thickening to the southeast (Figure 5.15 a). Evidence for abrupt thickening across the eastern boundary fault suggests it actively subsided during deposition of the Cisco-to-Atoka interval.

\subsubsection{Wolfcamp Interval}

Following culmination of the Ouachita-Marathon orogeny in the late Pennsylvanian, tectonic events are considered to have had much less influence on deposition of Permian and younger intervals in the Permian Basin. (Hills, 1970; Shumaker, 1992). However, the trend of the Wolfcamp is roughly due north and dips to the east (Figure 5.16), a trend that suggests influence of faults within the field. The time structure map reveals that subsequent uplift of the western boundary fault produced a structural high along the western border of the survey area. Post-Wolfcampian movement along the eastern boundary fault, however, appears to have been minimal or absent.

The isochron map of the Wolfcamp-to-Cisco reveals a pattern of westward thickening across the central block (Figure 5.17). This thickening suggests that differential rotation of the central block occurred down to the west along the western boundary fault. This stands in contrast to the pattern of thickening observed during 

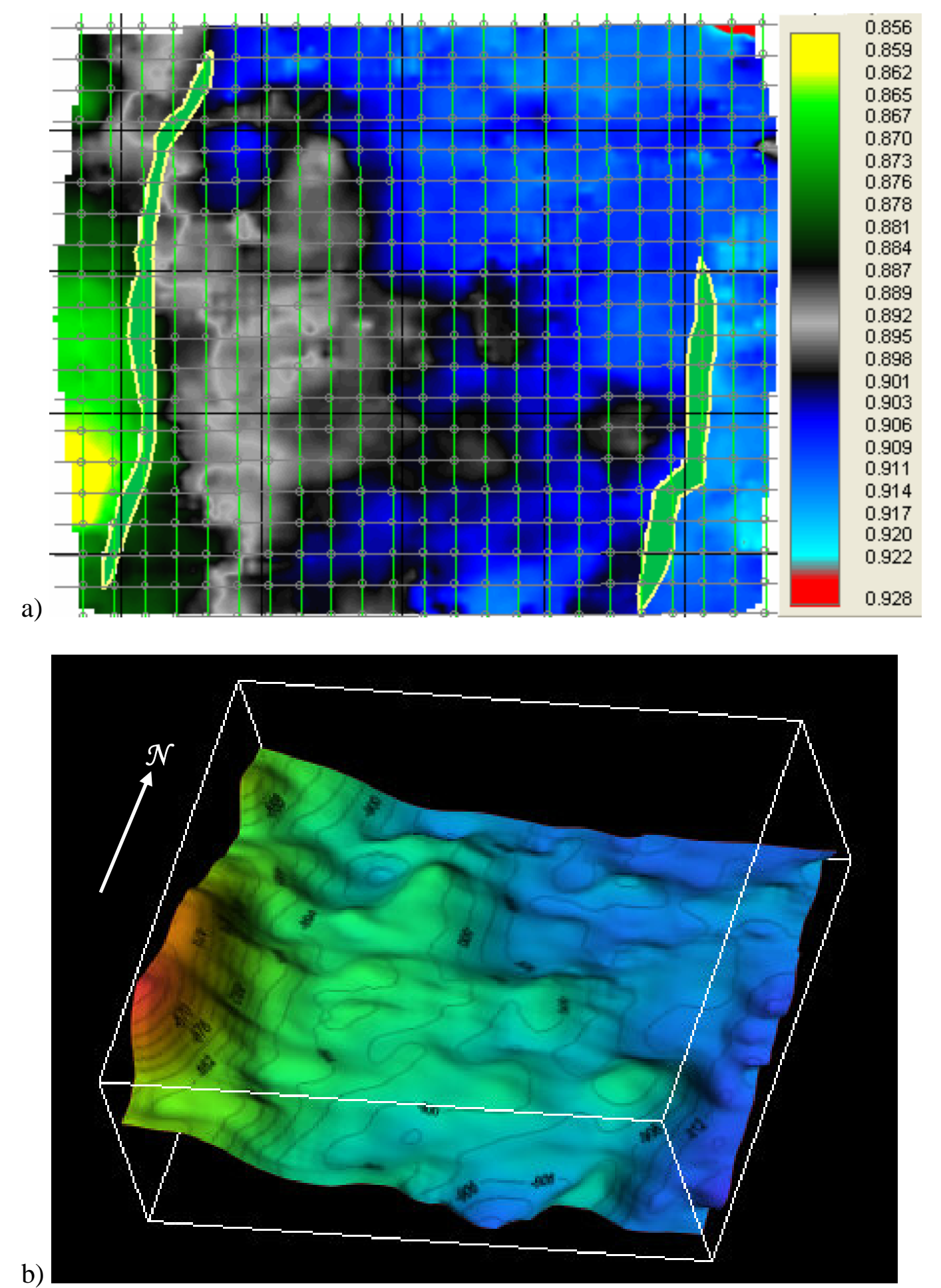

Figure 5.14 : a) Time structure on the Cisco reflection event; b) 3D perspective view of Cisco reflection event. Vertical exaggeration is 1:100 


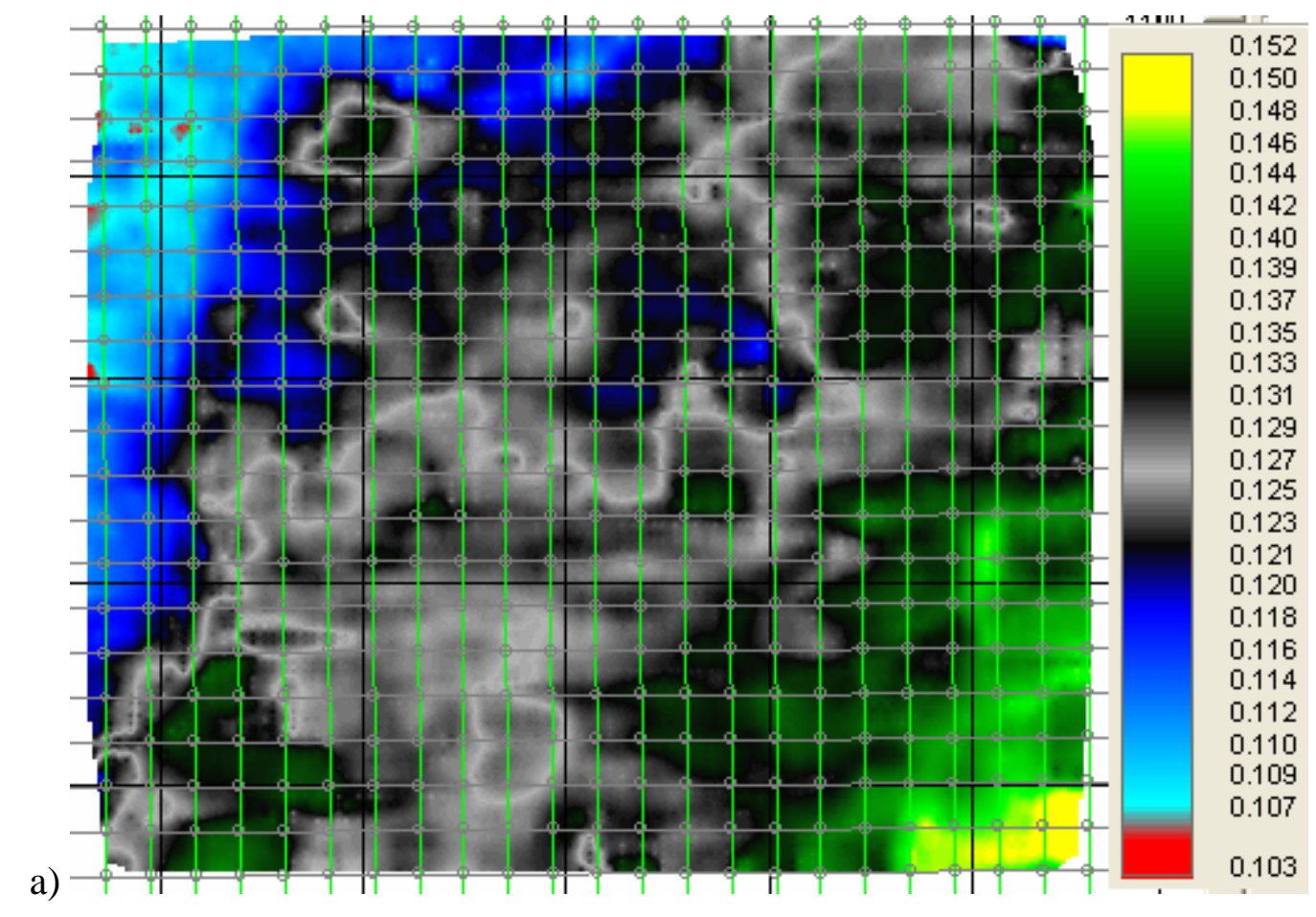

b)

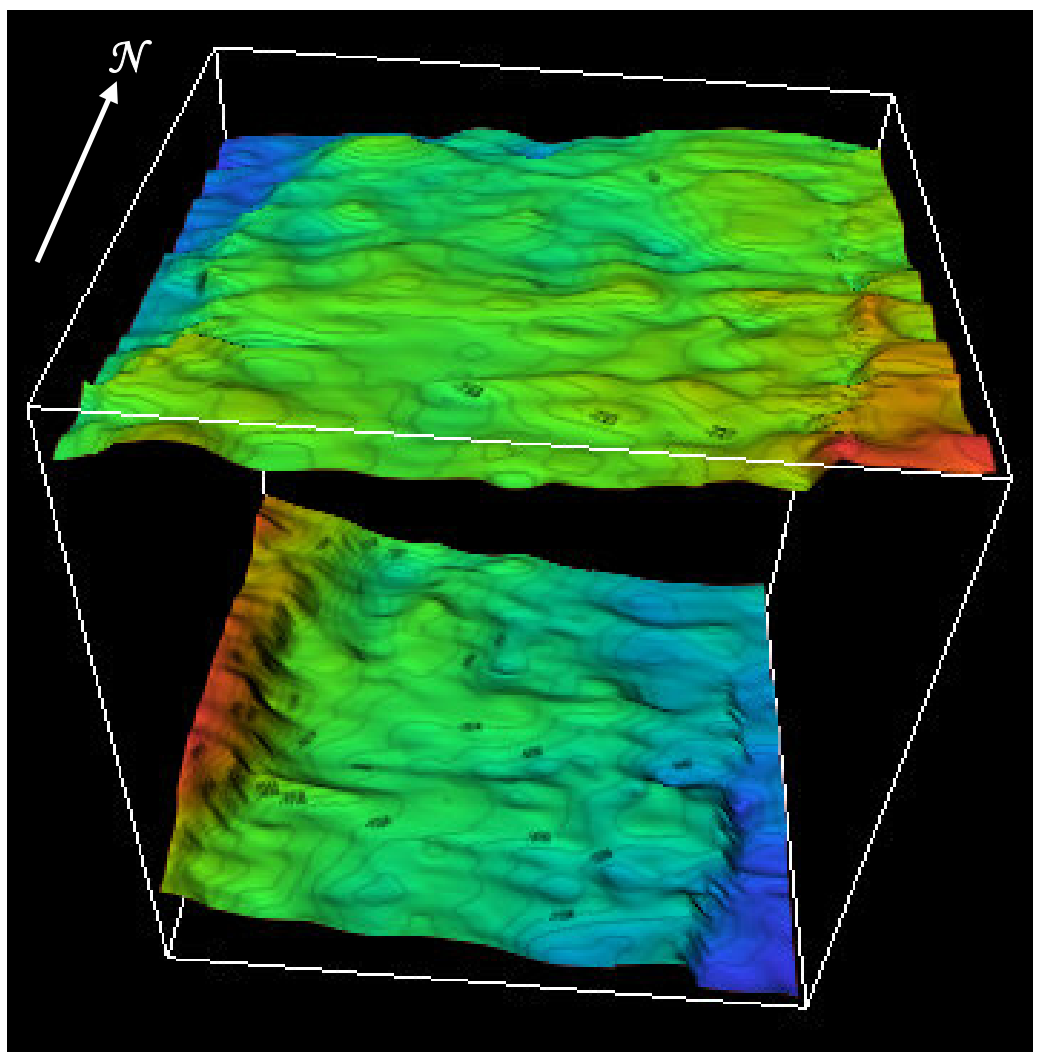

Figure $5.15:$ a) Isochron of the Cisco through Strawn interval; b) Isochron of the Cisco through Strawn overlaid on the Atoka time structure. 


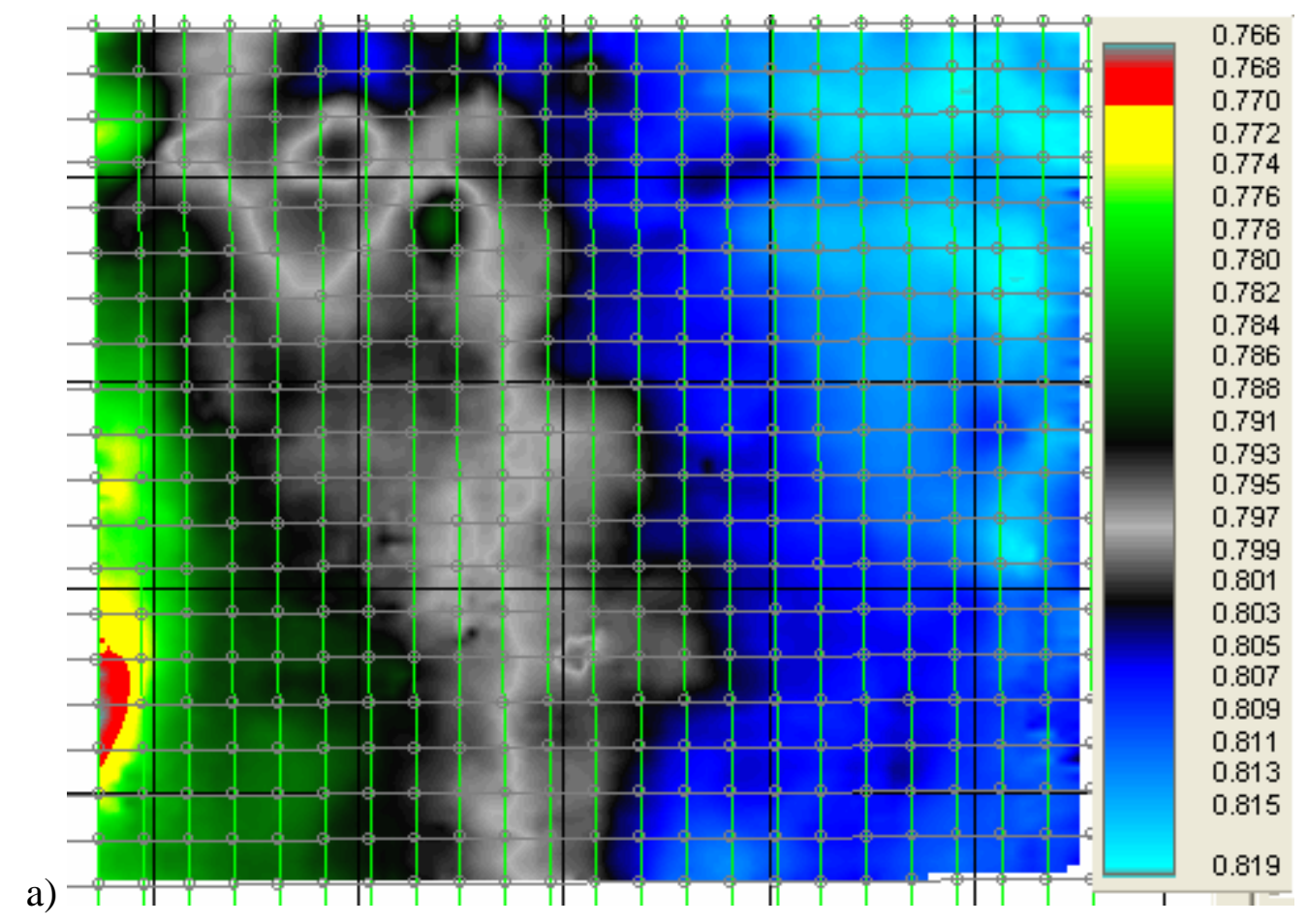

b)

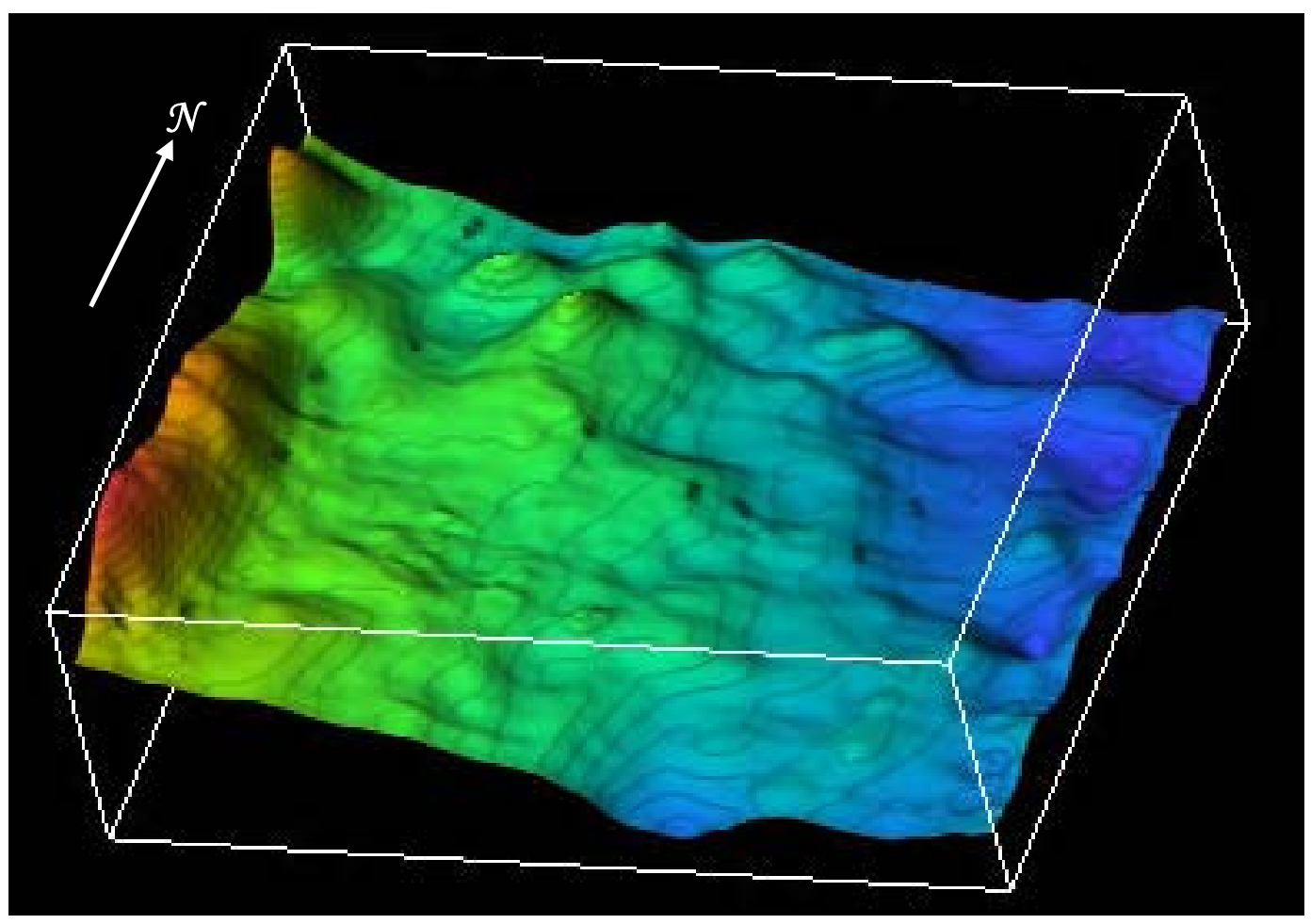

Figure 5.16: a) Time structure on the Wolfcamp reflection event; b) 3D perspective view of Wolfcamp reflection event. Vertical exaggeration is 1:100 

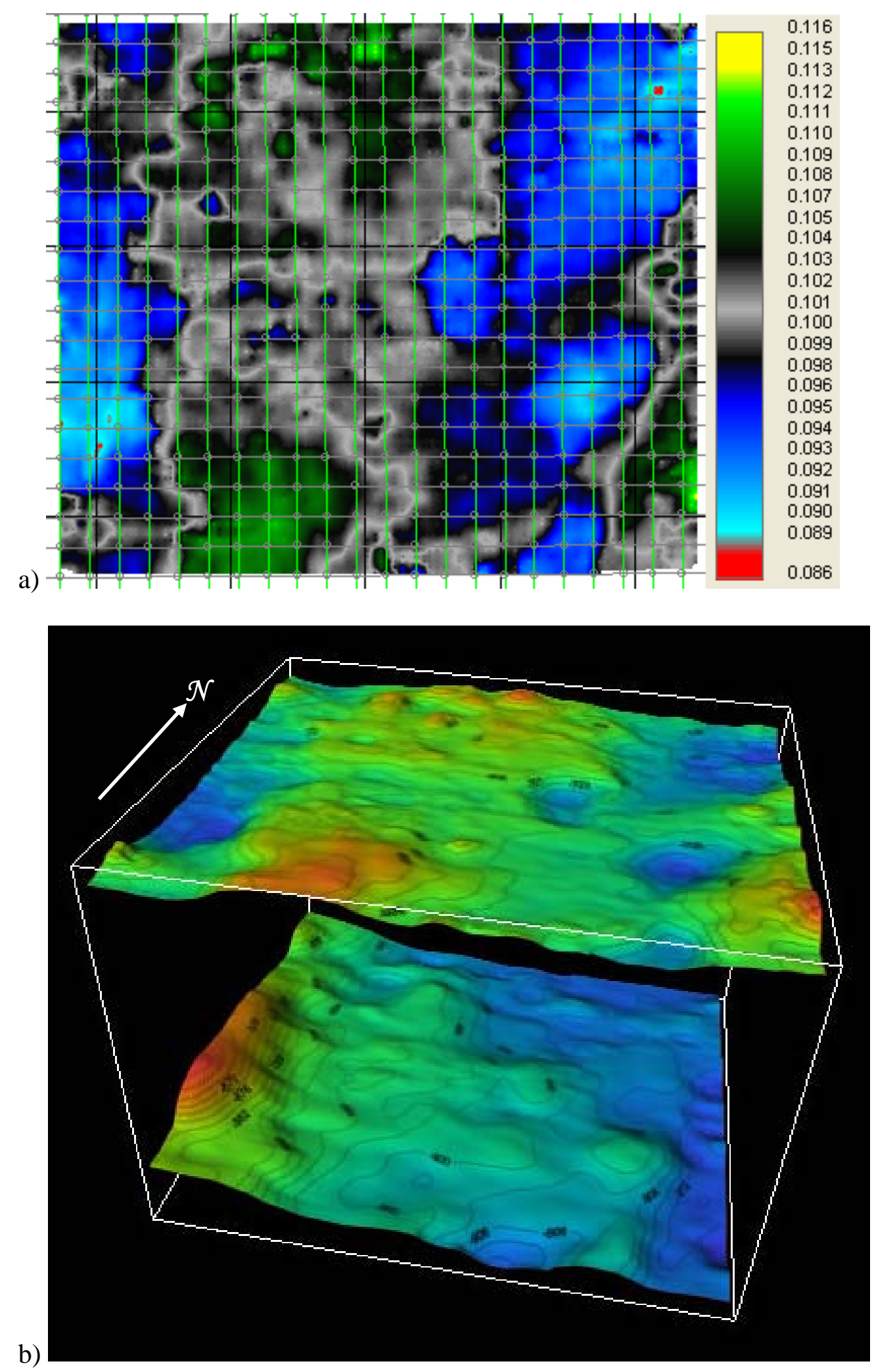

Figure 5.17: a) Isochron of the Wolfcamp event; b) Isochron of the Wolfcamp overlaid on the Cisco time structure. 
deposition of the Atoka-to-Morrow and Cisco-to-Strawn intervals. During deposition of those intervals, the central block rotated east and southeast, respectively.

Successive overlay of time structure on the Chester through Wolfcamp reflection events is illustrated in Figure 5.18. The figure reveals that the eastward dip into the Delaware Basin is interrupted by abrupt steps across the western boundary fault. The eastern boundary fault penetrates the Pennsylvanian formations, but is not visible in the Wolfcamp. Relief across the western boundary fault becomes progressively less through the Pennsylvanian and into the lower Permian Wolfcamp strata.

The isochron map of the Glorietta to Abo interval (Figure 5.19) also shows some tendency to thicken up against the eastern sides of the boundary faults; however, the most distinct feature associated with this interval is the pronounced thickening that occurs to the north throughout the survey area. In general, during earlier intervals there was a tendency for strata to thicken to the east and southeast into the Delaware Basin; thickening to the north observed during the Glorietta-to-Abo time period (lower-middle Permian) suggests significant inversion of earlier block motion. It may be that widespread erosion during the lower-middle Permian removed a thicker section in the southern part of the survey area. 


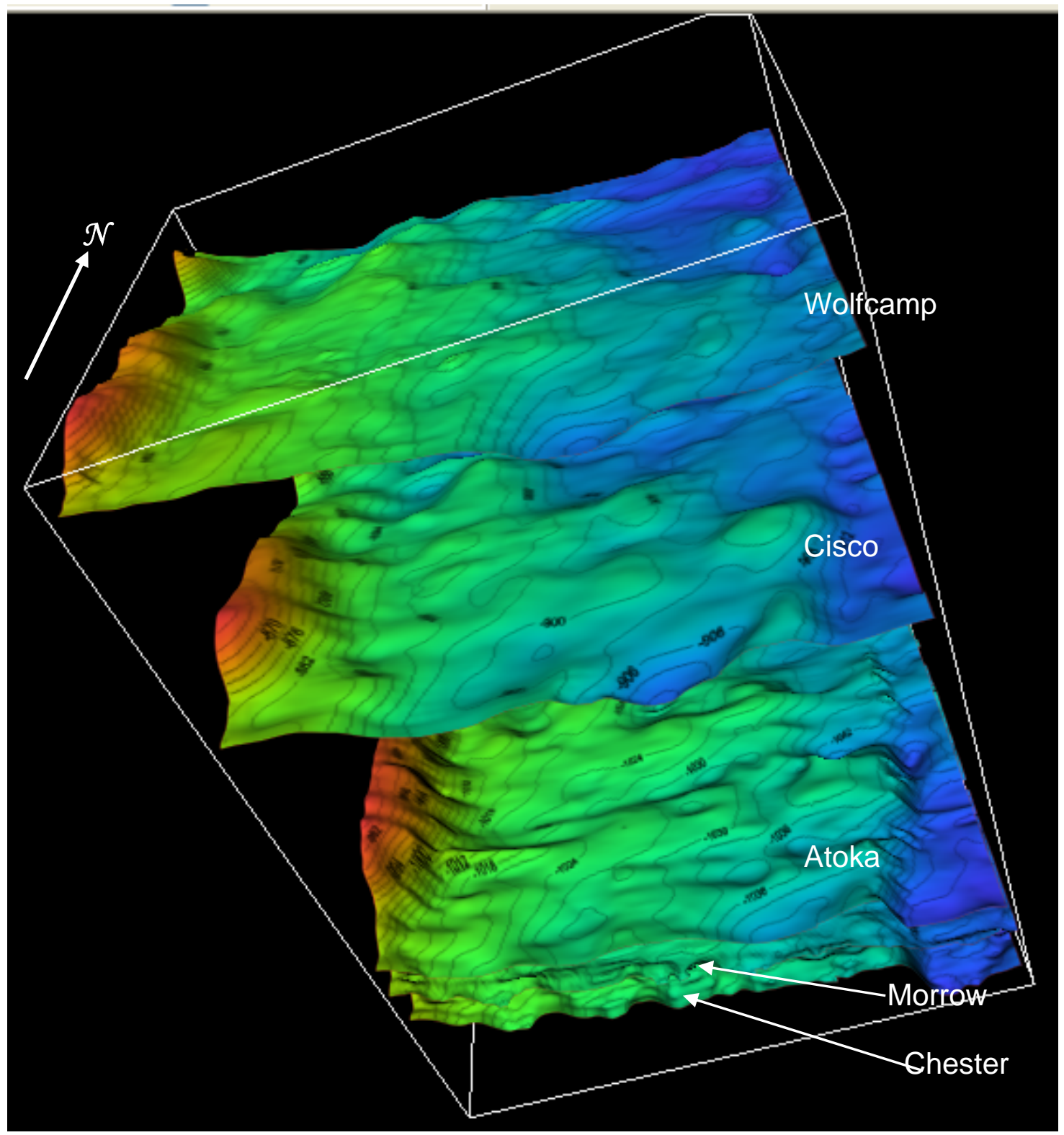

Figure 5.18: Comparison of time structure on the Chester through Wolfcamp reflection events. 


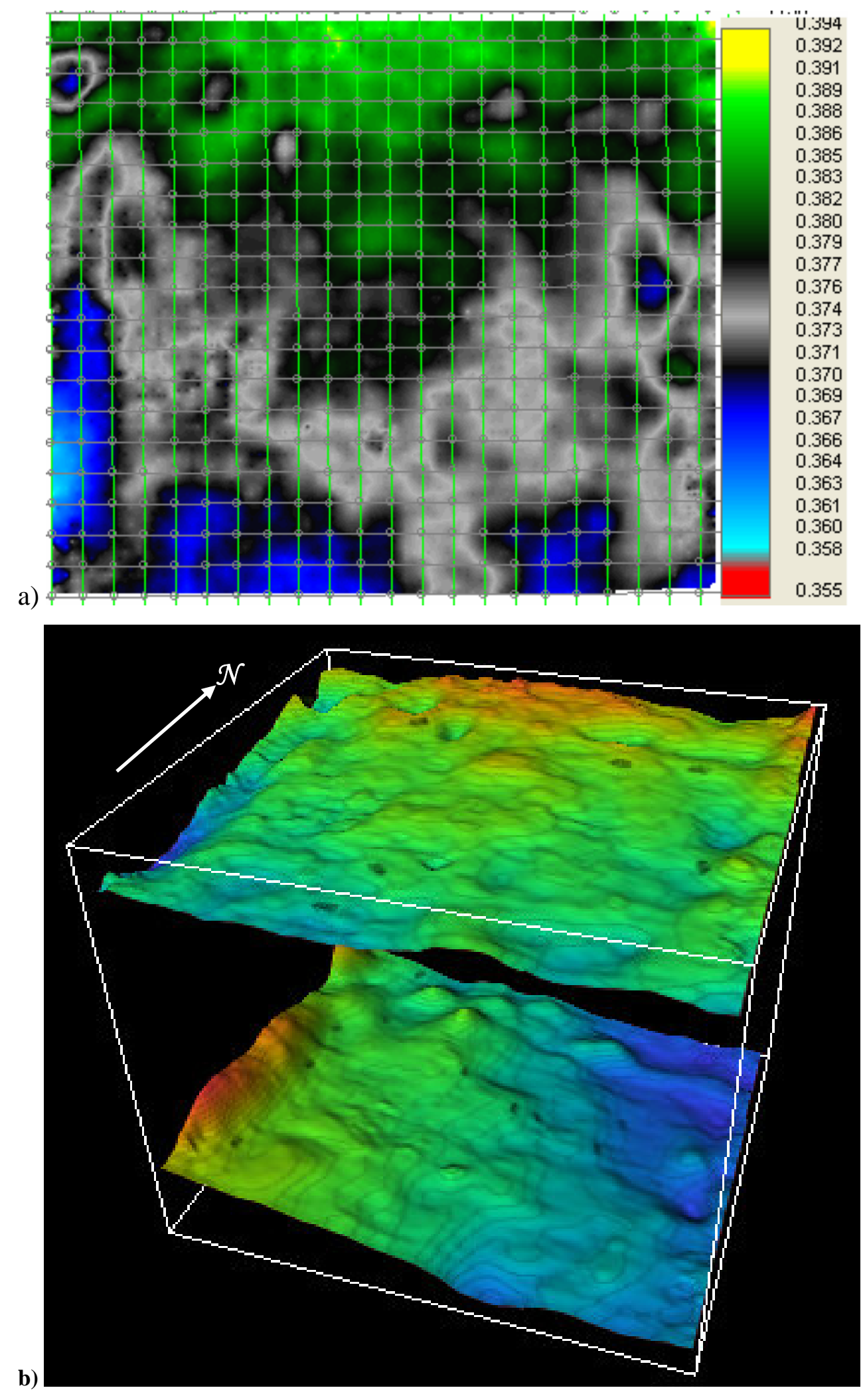

Figure 5.19: a) Isochron of the Glorietta-Abo interval; b) Isochron of the Glorietta-Abo interval overlaid on the Wolfcamp time structure 


\subsection{Seismic attributes and time Slice Interpretation}

3D seismic data volumes provide the capability to generate time slice views of the seismic response. The time slice provides a map view of the seismic response that often allows the interpreter to observe patterns associated with depositional systems. Simple time slice interpretation is often complicated by structural relief which may dominate features in the time slice (Bacon, 2003). Flattening the seismic volume to a given horizon allows the interpreter to minimize structural influences. In this study, time slices are extracted relative to flattened horizons to minimize the effects of structural relief, and to increase the likelihood of identifying stratigraphic elements associated within depositional systems. Time slices relative to a flattened horizon or reflection event provide detailed views of time synchronous depositional features. In areas with variable depositional trend and thickness, an average of the reflection amplitude or other attributes within a window of time centered on the reflection event may help uncover depositional elements such as channels, bars, levees, etc. Kingdom Suite allows the interpreter to calculate a variety of amplitude parameters including the RMS amplitude, average absolute value (AAV), peak amplitudes, and so on, within a given time window.

Sanchez (2005) restricted his analysis to amplitude slice maps. He used the Atoka reflection event as the datum for generating time slices. The basis for choosing the Atoka as a datum was that interpretation of the Atoka reflection event was less complicated than that of the Morrow and that time slices relative to the Atoka would be more likely to reveal depositional features. However, since the Atoka-Morrow interval thins to the west (see Figure 5.12), time slices datumed on the Atoka will actually cut through the Morrow and down into the upper Mississippian Barnett and Chester intervals. 
In this study, time slices of the attributes were generated and examined within time windows that include the lower Morrow channel sand. The data were flattened relative to the Morrow, Atoka or Chester reflection events. In addition, rather than restrict analysis to reflection amplitude along a given horizon-datumed time slice, the acoustic properties of larger volumes of strata were examined using the average absolute value (AAV), the root mean square (RMS), maximum, minimum and sum of attribute value within a given time gate. Investigations of the volume response offer increased potential to uncover patterns with stratigraphic elements whose thickness lie below the resolution limit.

A simple amplitude time slice using the Atoka or Morrow as a datum showed poor correlation with the production trend (e.g. figures 5.20, 5.21 and 5.22). Although, a high amplitude region in the northern part of the area showed some alignment with the high production trend, an association to production was not observed in the southern part of the area.

Wilson and Pyakurel (2005) examined the integrated amplitudes in a 20 millisecond window extending 20 ms up from the top of the $2^{\text {nd }}$ Chester (Figure 5.23). This time window includes the $1^{\text {st }}$ Chester, Barnett, Morrow and lower Atoka intervals. The integrated sum over this window reveals a pattern of highs in the summed amplitudes that are roughly associated with the high oil production trend. Indeed, areas of poor agreement between production distribution and integrated amplitude occur in areas of poor well control across which the production distribution is interpolated. 


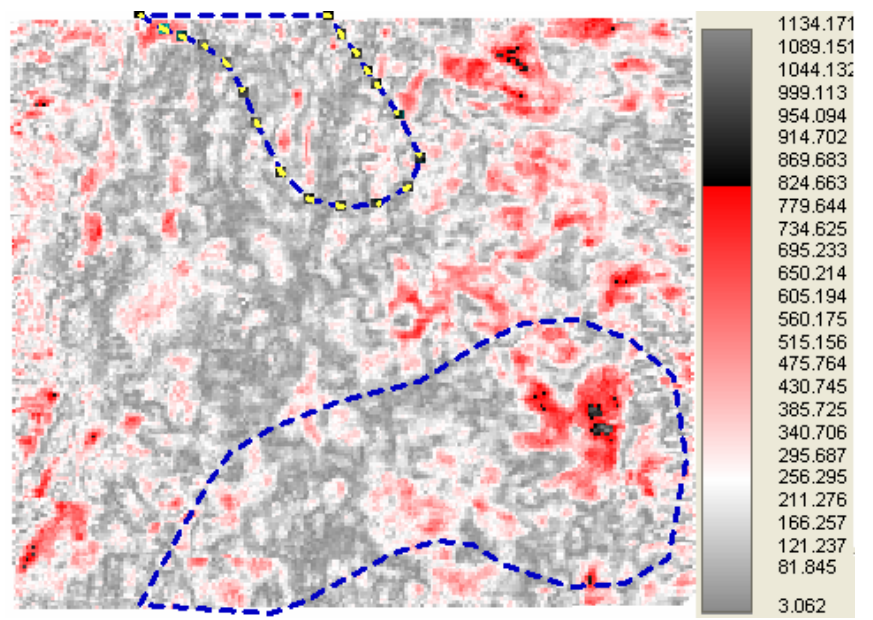

Figure 5.20 : AAV amplitude in a time window that extending from 6 t0 10 ms below the Morrow reflection event. The blue dotted polygon outlines areas with high production.

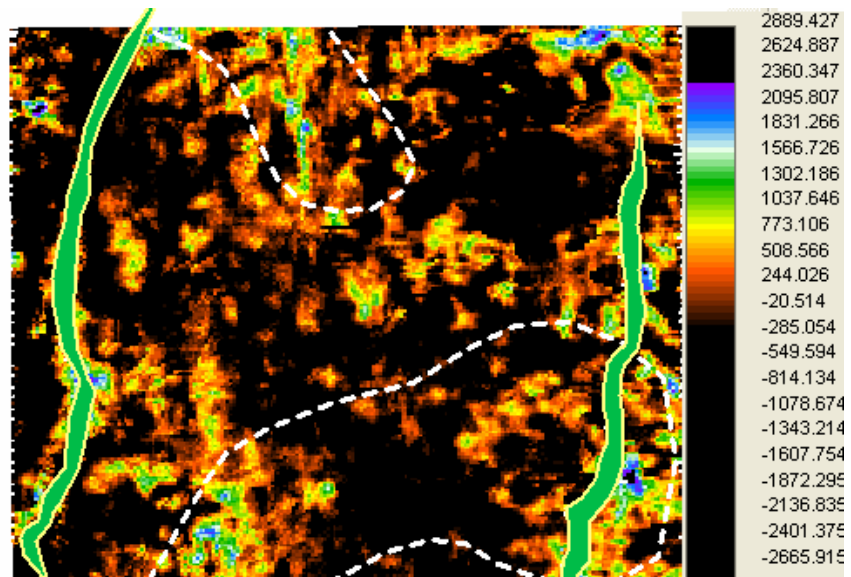

Figure 5.21: Integrated amplitude in a time window extending from 20 to $27 \mathrm{~ms}$ below the Atoka top. The white dotted polygon outlines areas with high production.

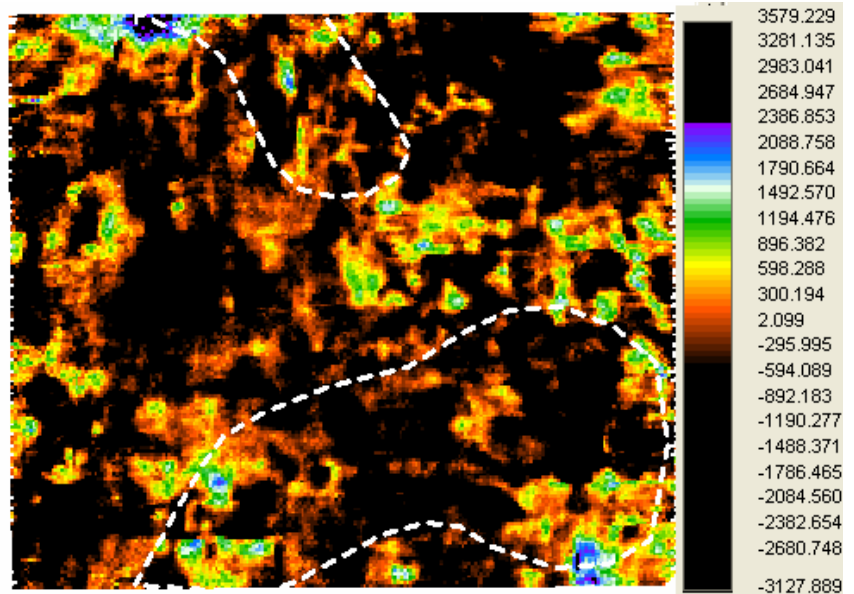

Figure 5.22: Integrated amplitude calculated for a $10 \mathrm{~ms}$ window of time extending down from the Morrow top. The white dotted polygon outlines areas with high production. 
Extensive attribute analysis conducted by Wilson and Pyakurel (2005) revealed that acoustic impedance had significant correlation to log properties in the Atoka to Chester time interval. The RMS impedances in a 16 ms window including the lower Atoka through Morrow events (Figure 5.24) reveal a trend of impedances that coincides roughly with the trend and distribution of production through the area. The RMS value of P-wave impedances (see chapter 6 for discussion of impedance computation) was calculated in a window extending from 10 ms below the Atoka event down to 9 ms below the Morrow event. Two-way travel time through the Morrow is approximately $10 \mathrm{~ms}$. The match of production to integrated amplitude and RMS acoustic impedance from time windows that straddle the Morrow interval suggest these volume attributes reveal the main course of the Harris Channel through the area. 


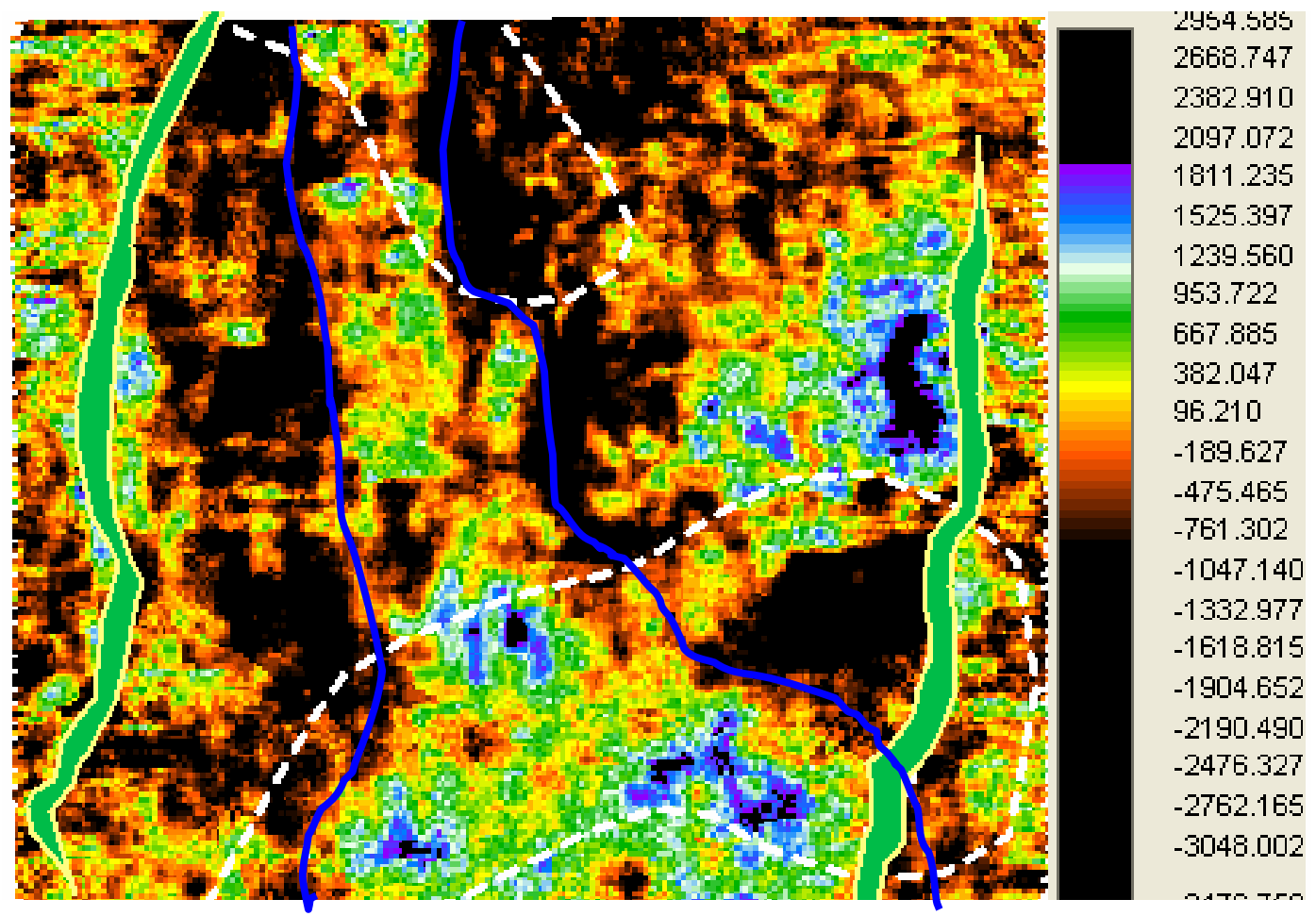

Figure 5.23: Integrated amplitude map calculated for a $20 \mathrm{~ms}$ window of time extending up from the Chester top. The dashed white polygon outlines regions with high production. The solid blue line outlines the region with high integrated amplitude.

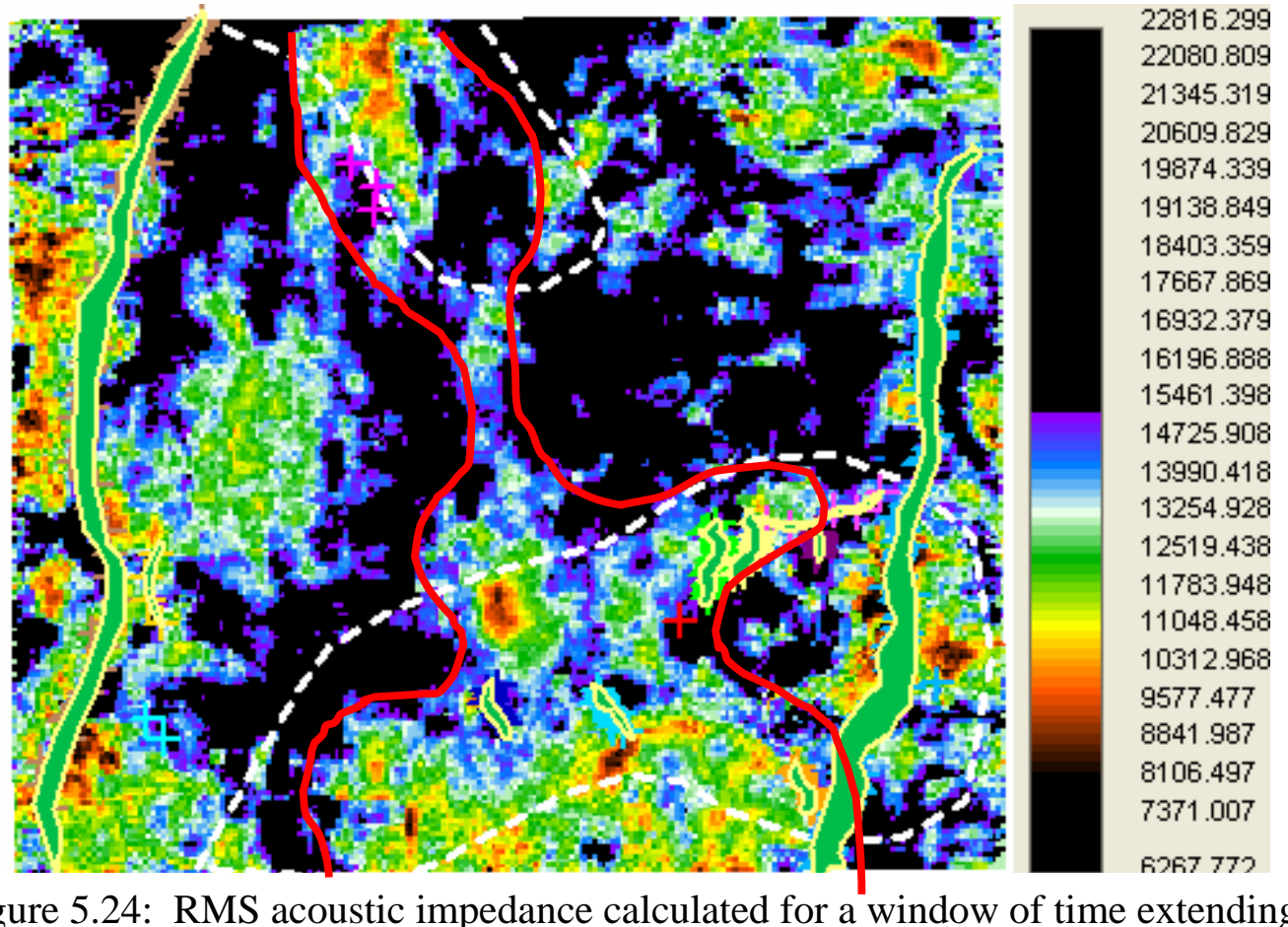

Figure 5.24: RMS acoustic impedance calculated for a window of time extending down from 10 ms below top of the Atoka to 9 ms below the Morrow top. The solid red line outlines the high impedance area. The dotted white polygon outlines areas with high production. 


\section{CHAPTER 6}

\section{CONVERTED PS WAVE INTERPRETATION}

\subsection{Introduction}

As noted earlier, WesternGeco provided both 3D P-wave and mode converted shear wave (PS-wave) seismic volumes. The mode converted shear wave (PS-wave) is a P-wave that is converted to an S-wave upon reflection. When a down-going P-wave strikes a reflective interface at a non-zero incidence angle it generates a shear wave reflection. The up-going S-wave is referred to as the PS-wave - the mode converted shear wave. The uses of converted PS waves in seismic exploration are increasing rapidly. Acquisition of converted shear wave data is less expensive than acquisition of primary shear wave data collected using a shear wave source (Stewart, 2003). The PS wave provides S wave information that when combined with the P-wave characteristics, can be directly related to the mechanical properties of rocks. For example, analysis of P-wave and PS-wave reflection arrival time variations with offset can be used to provide P- and $\mathrm{S}$-wave velocities. P-wave and $\mathrm{S}$-wave velocities $\left(\mathrm{V}_{\mathrm{p}}\right.$ and $\left.\mathrm{V}_{\mathrm{S}}\right)$ can then be combined to yield Poisson's ratio. The Poisson's ratio can in turn be used to interpret the lithology of the area. Analysis of converted shear wave data increases the potential outgrowths of seismic imaging and interpretation. Shear and converted shear waves also have potential application to the detection of fracture zones, interpretation of gas filled zones, lithology discrimination using PS wave attributes, reservoir monitoring, etc. (Stewart, 2003).

Figures 6.1 and 6.2 present a comparison of P-wave and PS-wave data sets along an east-west line through the Buffalo Valley 3D survey. Comparison of the two datasets 
reveals the presence of a zone of reduced amplitude and reflection coherence in the PSwave data (Figure 6.2) that is not observed in the P-wave section (Figure 6.1). This zone may be associated with a narrow zone of intensely fractured strata. As part of the processing flow, the $\mathrm{P}$ to $\mathrm{S}$ wave travel times were converted to equivalent $\mathrm{P}$-wave travel times. Thus, travel times to horizons interpreted in the P-wave data (Figure 6.1) are the same as the corrected travel times in the PS wave data set (Figure 6.2). Reflection continuity and relative amplitude of events differ considerably between the two data sets. The PS-wave data, although compared in time, have noticeably lower dominant frequency, and thus resolution, as discussed in Chapter 4.

\subsection{Seismic Inversion}

In this study, P and PS-wave data were inverted to acoustic impedance to allow estimation of $\mathrm{V}_{\mathrm{p}} / \mathrm{V}_{\mathrm{s}}$ ratios and the computation of Poisson's ratio. The acoustic inversion process can be regarded as the inverse of the forward modeling process used to predict the Earth’s seismic response. The forward modeling process is generally represented by the convolution of the seismic wavelet with the reflection coefficient train. In seismic inversion we use the seismic response as the input and back-calculate the acoustic impedances of subsurface intervals. A recursive inversion algorithm (see Russell, 1988) was used to estimate acoustic impedance as summarized below. The inversion algorithm is part of Kingdom Suite's TracePak tool kit. The quantitative basis for the recursive inversion algorithm is briefly outlined below. 


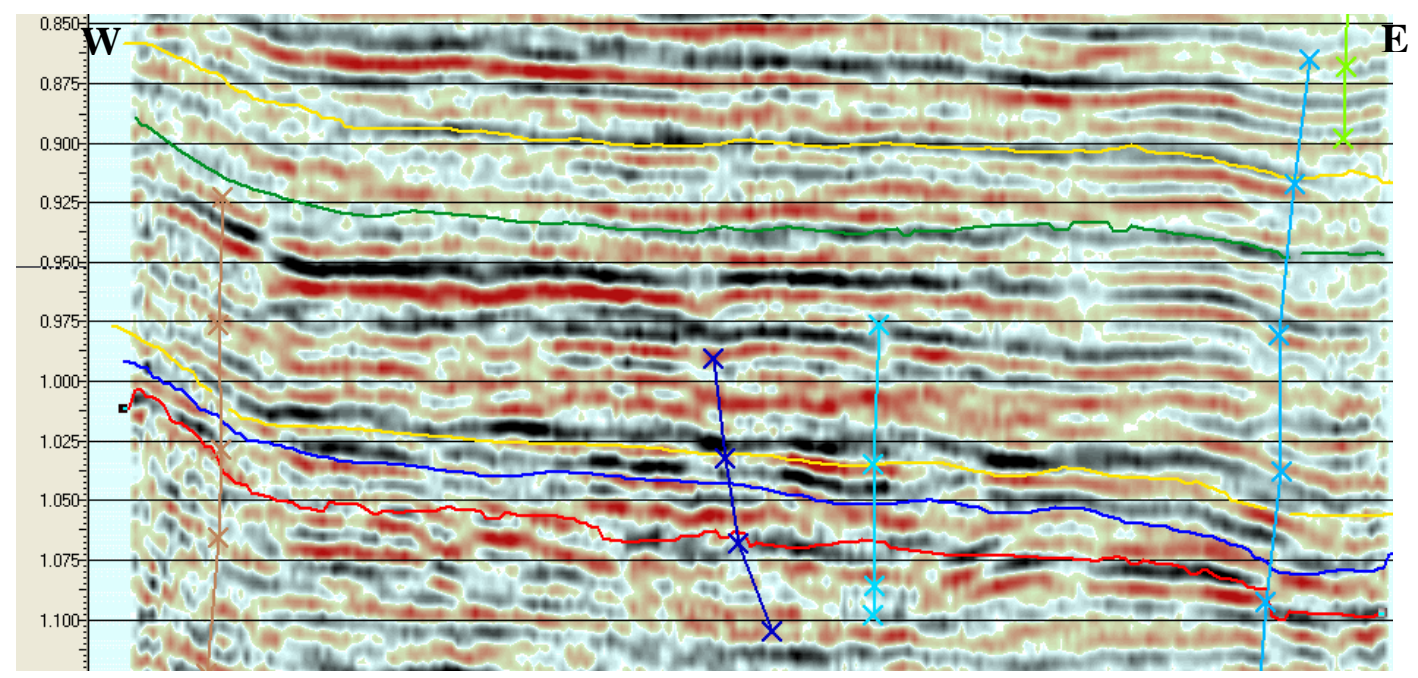

Figure 6.1: East-west seismic line from the P-wave 3D data volume.

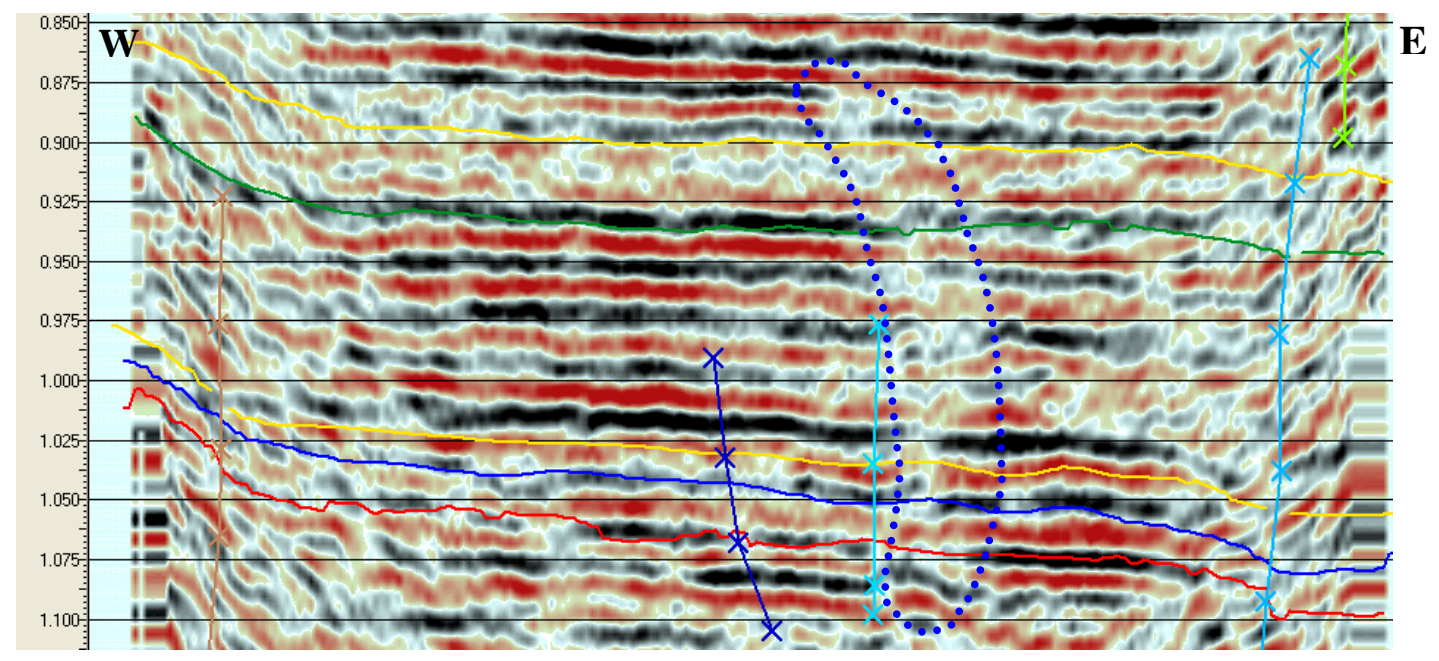

Figure 6.2: East-west seismic line from the PS-wave 3D data volume. Narrow zone of low reflection amplitude and coherence is outlined by the blue dotted line. 
The reflection coefficient for the $i^{\text {th }}$ layer can be written as:

$\mathrm{r}_{\mathrm{i}}=\frac{\rho_{i+1} \times v_{i+1}-\rho_{i} v_{i}}{\rho_{i+1} \times v_{i+1}+\rho_{i} v_{i}}=\frac{z_{i+1}-z_{i}}{z_{i+1}+z_{i}}$

where, $v_{i}$ is velocity and $\rho_{i}$ is density of the $i^{\text {th }}$ layer, $i+1$ refers to the layer immediately below the $\mathrm{i}^{\text {th }}$ layer and $\mathrm{z}$ is the acoustic impedance $\left(\mathrm{z}_{\mathrm{i}}=\rho_{\mathrm{i}} \mathrm{v}_{\mathrm{i}}\right)$.

Through substitution, $1=\frac{Z_{i+1}+Z_{i}}{Z_{i+1}+z_{i}}$; we can show that

$1+\mathrm{r}_{\mathrm{i}}=\frac{z_{i+1}+z_{i}}{z_{i+1}+z_{i}}+\frac{z_{i+1}-z_{i}}{z_{i+1}+z_{i}}=\frac{2 z_{i+1}}{z_{i+1}+z_{i}}$

and that,

$1-\mathrm{r}_{\mathrm{i}}=\frac{z_{i+1}+z_{i}}{Z_{i+1}+z_{i}}-\frac{z_{i+1}-z_{i}}{z_{i+1}+z_{i}}=\frac{2 z_{i+1}}{Z_{i+1}+z_{i}}$

Division of eq.(6.1) by (6.2) yields,

$\frac{Z_{i+1}}{Z_{i}}=\frac{1+r_{i}}{1-r_{i}}$

Hence, the acoustic impedance of $\mathrm{i}+1$ layer is given as,

$\therefore z_{i+1}=z_{i}\left(\frac{1+r_{i}}{1-r_{i}}\right)$

Finally, the impedance for the nth layer can be calculated as,

$z_{n}=z_{1} \prod_{i=1}^{n-1}\left(\frac{1+r_{i}}{1-r_{i}}\right)$

The above relationship assumes that reflection amplitudes observed in the seismic record are directly proportional to the reflection coefficients producing them. The above inversion algorithm also assumes that differences in reflection coefficients are relatively small. 


\subsection{1 $P$ and PS-wave inversion}

The P-wave and PS-wave data were inverted using a high frequency recursive inversion method with low and high cut frequencies of 0 and $85 \mathrm{~Hz}$ respectively. Near surface velocities of $13500 \mathrm{ft} / \mathrm{s}$ and $7800 \mathrm{ft} / \mathrm{s}$ were used for the P-wave and PS-wave inversion respectively. The inverted data reveal that the range of $\mathrm{P}$-wave impedances and impedance contrasts is greater than that observed in the PS-wave data (see figures 6.3 and 6.4). The $\mathrm{P}$ and PS-wave acoustic impedances were averaged over a 5 ms window extending from $5 \mathrm{~ms}$ to $10 \mathrm{~ms}$ below the Morrow top to examine the possibility that average impedance in this $5 \mathrm{~ms}$ window may allow possible differentiation of sand rich versus limestone rich intervals in proximity to the Harris Channel. The 5 ms window is interpreted to correspond roughly to the Morrow channel sand interval, which lies 75-115 ft below the Morrow top. Averaging may also help resolve spatial patterns of channel deposition that are not resolvable at single instant in time.

The map of average P-wave impedance (Figure 6.5) reveals high impedance trends (black areas) that roughly skirt the NW to SE trend of high production through the central area of the 3D survey. Intermediate impedance trend (green to orange) extend trough the center of the field. Areas of intermediate PS-wave impedance also extend through the central and southern parts of the survey area along the high production trends (Figure 6.6). The $\mathrm{V}_{\mathrm{p}} / \mathrm{V}_{\mathrm{s}}$ ratio is illustrated in the Figure 6.7. Intermediate values of $\mathrm{V}_{\mathrm{p}} / \mathrm{V}_{\mathrm{s}}$ (1.4 to 1.85 ) show some association with the high production trends. The coincidence of $\mathrm{P}$ and PS- impedance and $\mathrm{V}_{\mathrm{p}} / \mathrm{V}_{\mathrm{s}}$ ratio trends with production and channel sand distribution is explored further by estimating the distribution of Poisson's ratio within this interval. 


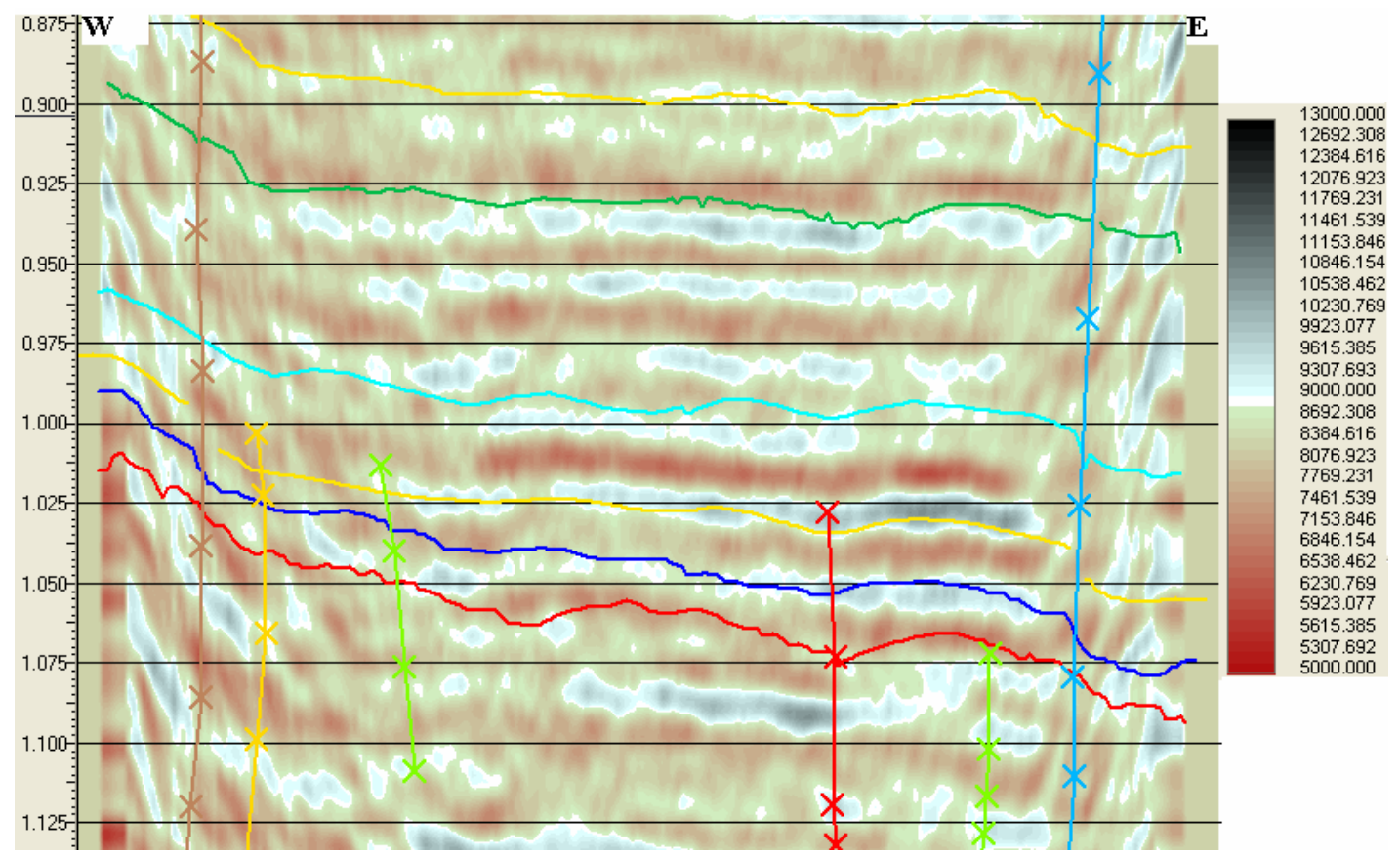

Figure 6.3: Acoustic impedance calculated for the PS-wave data along an E-W line through the 3D survey.

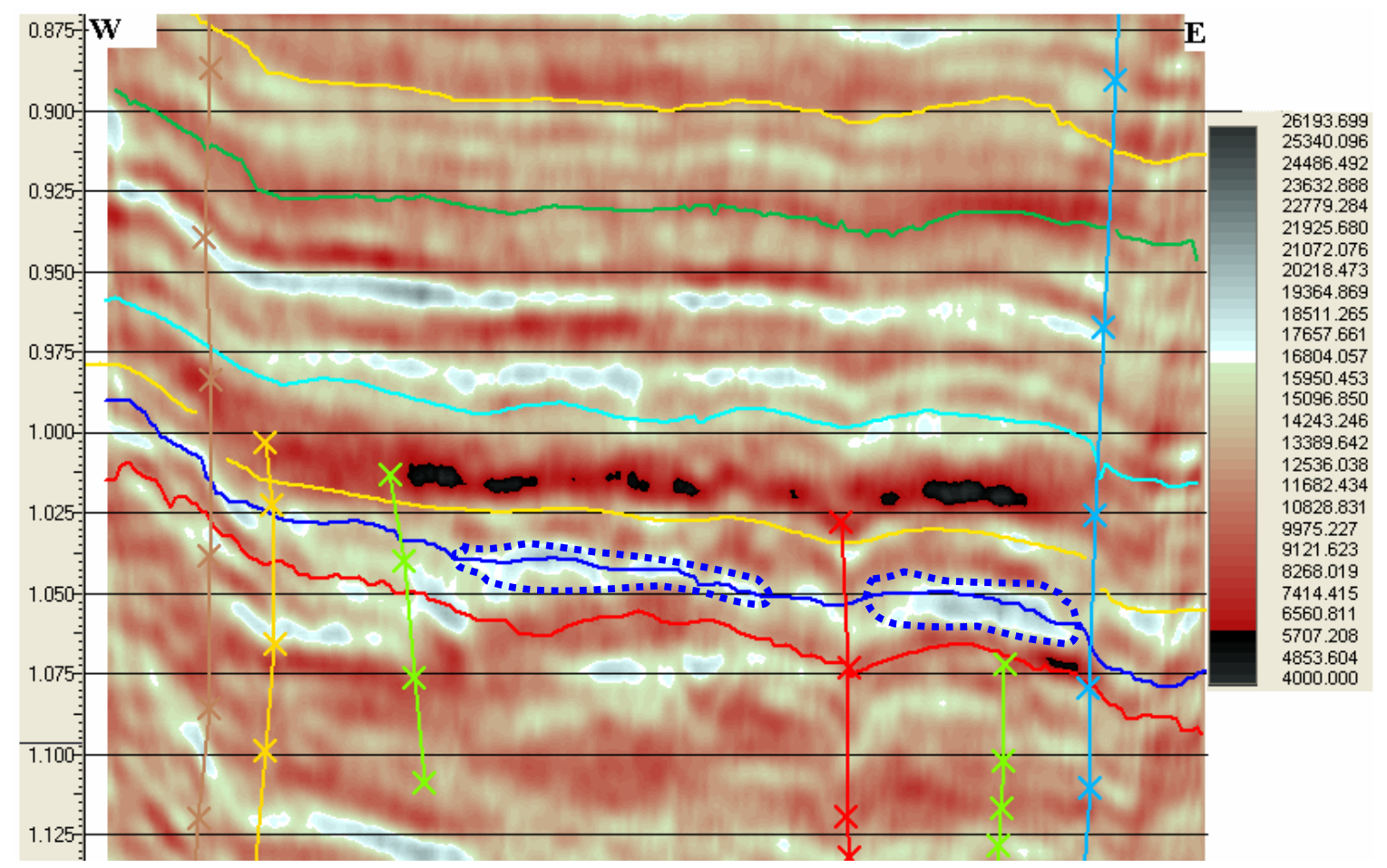

Figure 6.4: Acoustic impedance calculated for the P-wave data along an E-W line (same as in Figure 6.3) through the 3D survey. The blue dotted line highlights a zone of intermediate acoustic impedance used as a guide to help pick the Morrow reflection event. 


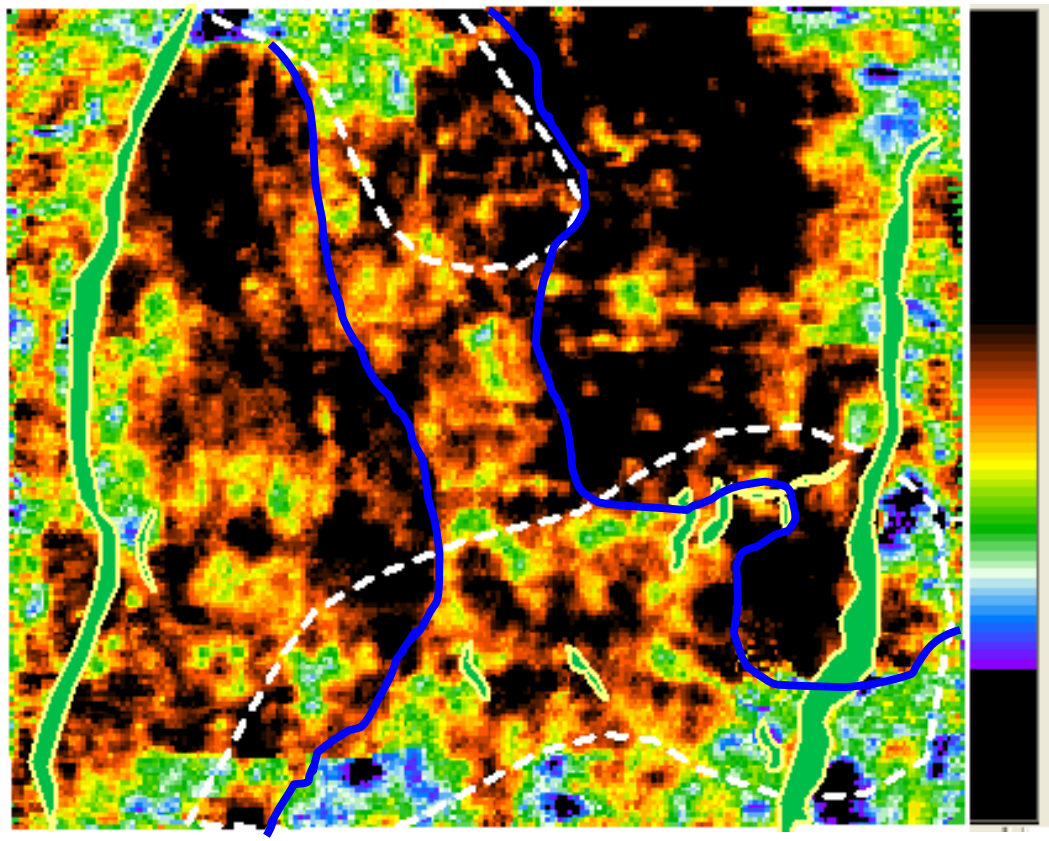

23443069

22678.275

21913.481

21148.687

20383.892

19619.098

18854.304

18089.510

17324.716

16559.922

15795.127

15030.333

14265.539

13500.745

12735.951

11971.156

11206.362

10441.568

9676.774

8911.980

8147.185

6999.994

Figure 6.5: Map view showing variations in the average P-wave acoustic impedance within a 5 millisecond window of data extending from $5 \mathrm{~ms}$ to $10 \mathrm{~ms}$ below the Morrow reflection event. The solid blue line outlines areas of average impedance that may be associated with channel sands. High production trend is outlined by the white dashed line.

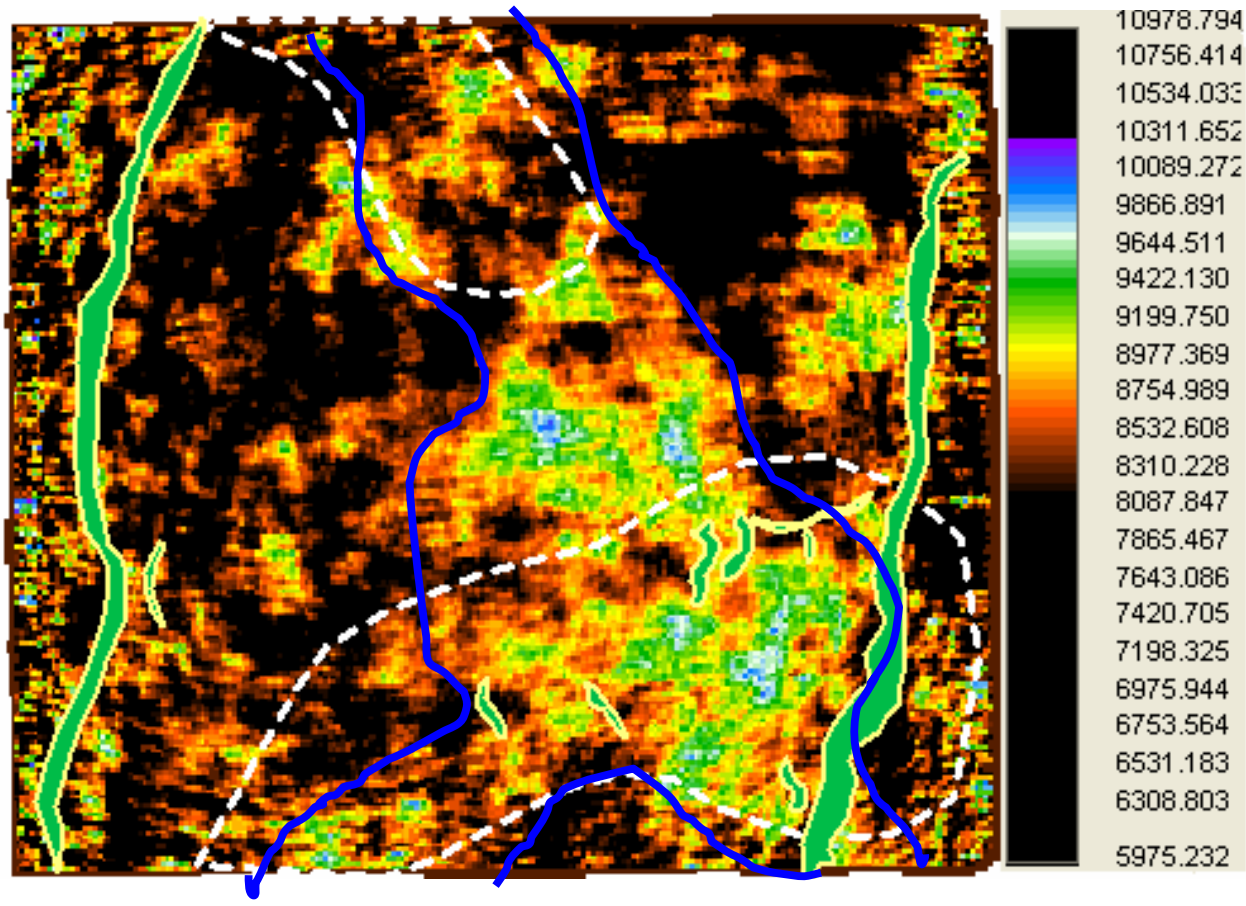

Figure 6.6: Map view showing variations in the average PS-wave acoustic impedance in a 5 millisecond window of data extending from $5 \mathrm{~ms}$ to $10 \mathrm{~ms}$ below the Morrow reflection event. The solid blue line outlines areas of average impedance that may be associated with channel sands. High production trend is outlined by the white dashed line. 


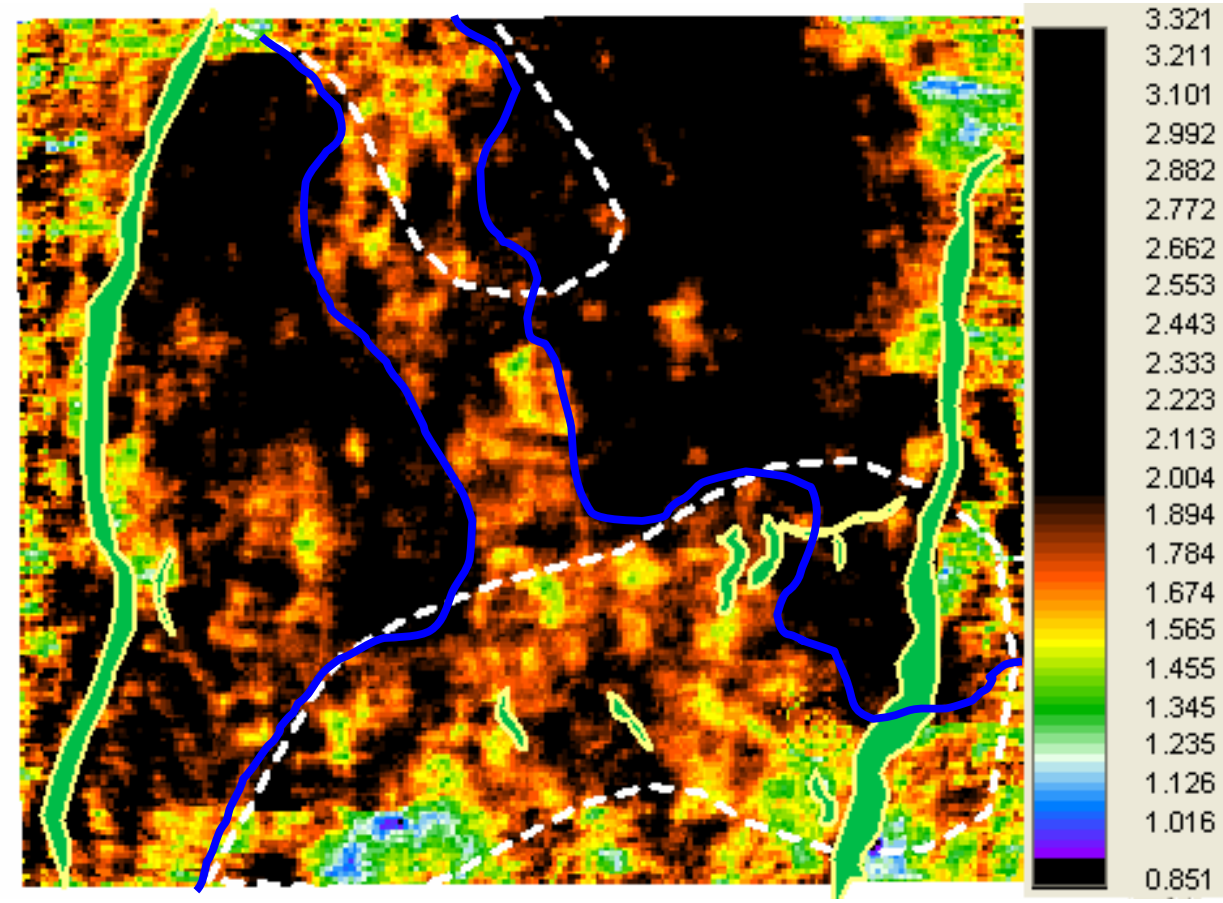

Figure 6.7: $\mathrm{Vp} / \mathrm{Vs}$ ratio computed from the inverted P-wave and PS-wave data volume in a 5 millisecond window of data extending from $5 \mathrm{~ms}$ to $10 \mathrm{~ms}$ below the Morrow reflection event. A good correlation is observed between the high production trend (outlined by white dotted line) and the $\mathrm{Vp} / \mathrm{Vs}$ ratio distribution. The solid blue line outlines areas of average $\mathrm{Vp} / \mathrm{Vs}$ ratio that may be associated with channel sands. 


\subsection{Poisson's ratio}

The Poisson's ratio is the ratio of transverse to longitudinal strain in samples subjected to uniaxial compression or extension. Poisson's ratio is a property that can be related directly to lithology. In the preceding section, acoustic impedances were extracted for the P and PS-wave data. Acoustic impedance $(\mathrm{Z})$ is defined simply as " $\rho \mathrm{V}$ ” where $\rho$ is the bulk density and $V$ is the interval velocity. Thus, $Z_{p}$, the $P$-wave impedance, is $\rho V_{p}$ and $Z_{s}$, the PS-wave impedance, is $\rho V_{s}$. In the ratio $Z_{p} / Z_{s}$, the density cancels out so that $\mathrm{Z}_{\mathrm{p}} / \mathrm{Z}_{\mathrm{s}}=\mathrm{V}_{\mathrm{p}} / \mathrm{V}_{\mathrm{s}}$. Thus, the ratio of the P-wave acoustic impedances to PS-wave impedance (figures 6.5 and 6.6 respectively) yields the $\mathrm{V}_{\mathrm{p}} / \mathrm{V}_{\mathrm{s}}$ ratio (Figure 4.7 ). Poisson's ratio $(\sigma)$, in turn is computed directly from the $\mathrm{V}_{\mathrm{p}} / \mathrm{V}_{\mathrm{s}}$ ratio as shown below:

$$
\sigma=\frac{\left(V_{p}^{2} / 2 V_{s}^{2}\right)-1}{\left(V_{p} / V_{s}\right)^{2}-1}
$$

\subsubsection{Poisson's ratio scaling}

Poisson's ratio calculated from the inverted P-wave and PS-wave impedances yielded Poisson's ratios concentrated in the -1 to 0.4 range (Figure 6.8). Approximately, $93 \%$ of the calculated ratios fall in this range with the remaining values $<-1$ and $>0.4$. Note that Poisson's ratios are generally distributed from 0 to 0.5 . There are several reasons why values outside the normal 0 to 0.5 range might occur: for example, lower bandwidth of the PS-wave data and slight mismatch between the corrected PS-wave and P-wave travel times. A negative Poisson's ratio is obtained when the $\mathrm{Vp} / \mathrm{Vs}$ ratio lies in the 1.1 to 1.41 range. 


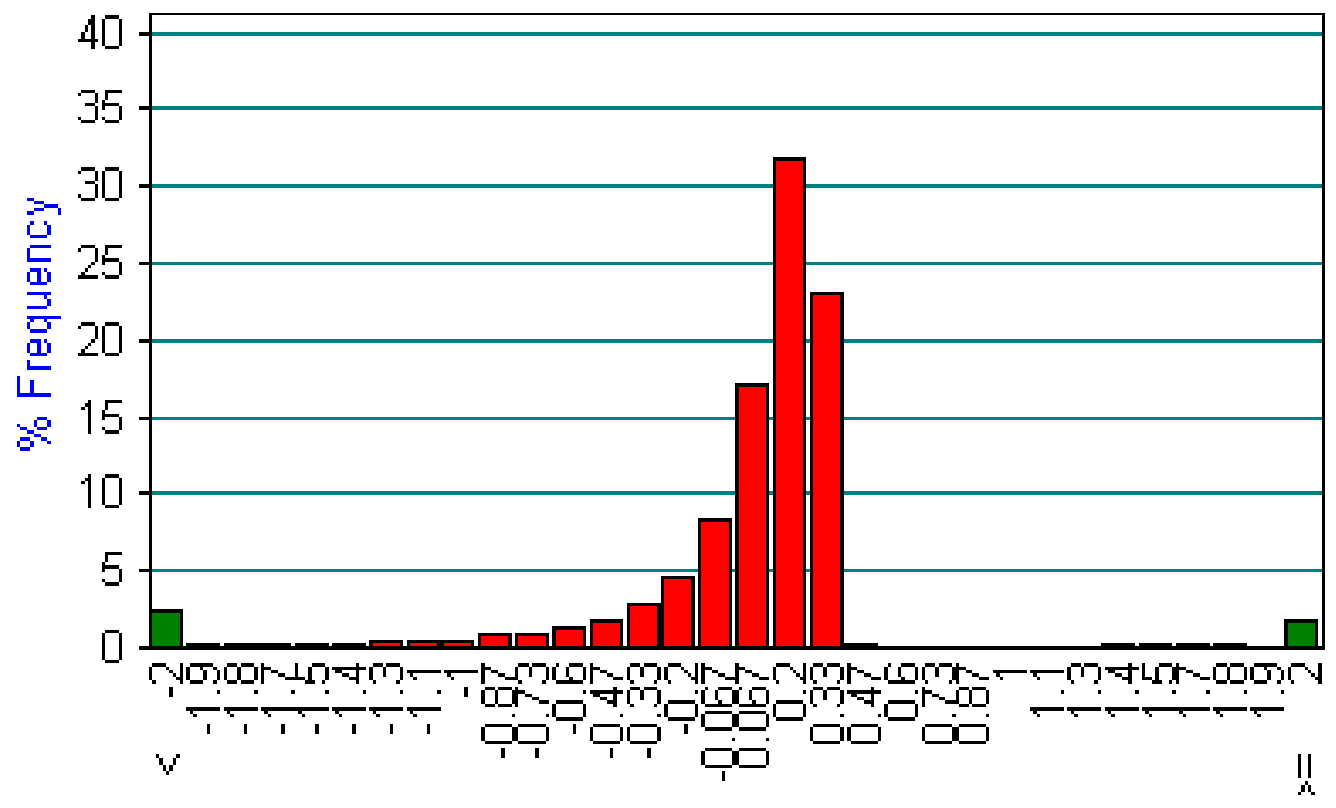

Figure 6.8: Poisson's ratios computed from the 3D impedance volume prior to scaling. Data greater than 2 and less than -2 were excluded from the histogram. 
For example, P and S-wave with velocities of $16500 \mathrm{ft} / \mathrm{s}$ and $15000 \mathrm{ft} / \mathrm{s}$ will yield a negative Poisson's ratio of -1.88 . Similarly, Poisson's ratios are greater than 0.5 whenever S-wave velocity is greater than the P-wave velocity. An examination of the effects of tuning, bandwidth and a slight shift in the P and PS responses is beyond the scope of this research. Such an evaluation would require that a series of synthetic seismograms be constructed for both the P and PS-wave data for models that included tuned sub resolution layers. Inversions of the synthetics could then be used to derive $\mathrm{V}_{\mathrm{p}} / \mathrm{V}_{\mathrm{s}}$ ratios and Poisson's ratios. The models developed by Sanchez (2004) would serve as a good starting point for a general examination of anomalous results that could arise in application of the procedures used in this study. Variations in bandwidth, bandwidth controlled tuning, and slight time-shifting between data sets will likely give rise to inversion derived $\mathrm{V}_{\mathrm{p}} / \mathrm{V}_{\mathrm{s}}$ ratios outside normal range, and consequently to anomalous and extreme values of Poisson's ratios.

In this study, we decided to scale the distribution of Poisson's ratios computed from the P and PS-wave inversions to approximate the range of Poisson's ratios computed from the dipole sonic log of the Lula 3 well over the same stratigraphic interval. The $\mathrm{Vp} / \mathrm{Vs}$ ratio and Poisson's ratio derived from the velocity logs in the Lula 3 well are illustrated in the Figure 6.9. This figure also displays the gamma ray and density logs to help interpret the lithology (sand vs. shale and sand vs. carbonates). The log derived ratios in the zone of interest (from $8403 \mathrm{ft}$ to $8667 \mathrm{ft}$ ) varied from approximately 0.2 to 0.3 (Figure 6.9). The Poisson's ratio for sandstones in this zone varied from approximately 0.2 to 0.27 . Sandstone with Poisson's ratio near 0.27 may represent calcareous sand with significant cement. A plot of Vp/Vs ratio vs. Poisson's ratio is illustrated in the Figure 
(6.10). This figure highlights the cutoff boundaries for lithologic sub-divisions. The distribution of Poisson's ratios for geologic materials is shown in Figure 6.11. Weathered layers have fairly large Poisson's ratios and large $\mathrm{V}_{\mathrm{p}} / \mathrm{V}_{\mathrm{s}}$ ratios. The shear wave velocity in unconsolidated weathered materials usually drops by a greater percentage than does the compressional wave velocity. In gas sands, partial support provided by fluid pressure is often removed, so that the shear wave velocity increases while the compressional wave velocity decreases. Poisson's ratios calculated from log data for these Pennsylvanian age strata fall in the sandstone, limestone and shale range (see Figure 6.11). In general, Poisson's ratios calculated from logs in the Lula \#3 well (Figure 6.9) for sandstone and carbonates show similar values to the Poisson's ratio calculated by Hilterman (2001) (Figure 6.11).

Using the Poisson's ratio calculated from the sonic log in the Lula 3 well as a guide, the Poisson's ratio calculated from the seismic inversions (Figure 6.8) were compressed into the range of values shown in the Figure 6.9. We assume that exceptionally high Poisson's ratios associated with loose unconsolidated materials are not present in the target strata; we also assume that some intervals could be gas filled and that low, near zero, Poisson's ratios may be a possibility. Hence, the -1 to 0.4 range of Poisson's ratio calculated from seismic inversion was compressed into a 0 to 0.31 range. The steps used to scale the data are described below.

i) Given, $A_{1}=$ Poisson's ratio before scaling

ii) Subtract the maximum value in the specified input range from each value (A1) to get $A_{2}$ i.e., $A_{2}=A_{1}-0.4$ 
iii) Calculate the scaling factor (SF) equals the range of Poisson's ratio observed in the well logs divided by the range of Poisson's ratios in the seismic, i.e., $S F=\frac{0.31-0.1}{0.4-(-1.1)}=0.14$

iv) Multiply A2 by the scale factor to get $A_{3}$ i.e., $A_{3}=A_{2} * 0.14$

v) Add the maximum value of desired range to $A_{3}$, i.e., $A_{4}=A_{3}+0.031$

Overall, the scaling operation can be summarized as a single equation:

$$
A_{4}=\left(A_{1}-c\right) * S F+P_{\max },
$$

where, $\mathrm{A}_{4}=$ final scaled data, $\mathrm{A}_{1}=$ unscaled data, $\mathrm{c}=$ constant (upper limit of the data range to be scaled), $\mathrm{SF}=$ Scaling factor, $\mathrm{P}_{\max }=$ Upper limit of the desired scale range (computed from well logs). The scaling operation (Equation 6.6) was undertaken using Kingdom Suite’s TracePak trace calculation utility.

The -1.1 to 0.4 range Poisson's ratios selected for comparison were based on the shape of the distribution (Figure 6.8). The distribution of Poisson's ratios (Figure 6.8) calculated from the seismic data are concentrated in the -1.1 to 0.4 range and have a distribution similar to that shown in Figure 6.11. The rescaling operation preserves the shape of the distribution, but redistributes values into the 0 to 0.31 range (Figure 6.12). 




Figure 6.9: Vp/Vs and Poisson's ratio plot from the velocity log in the Lula 3 well computed between 8403 to 8667 depth interval. 


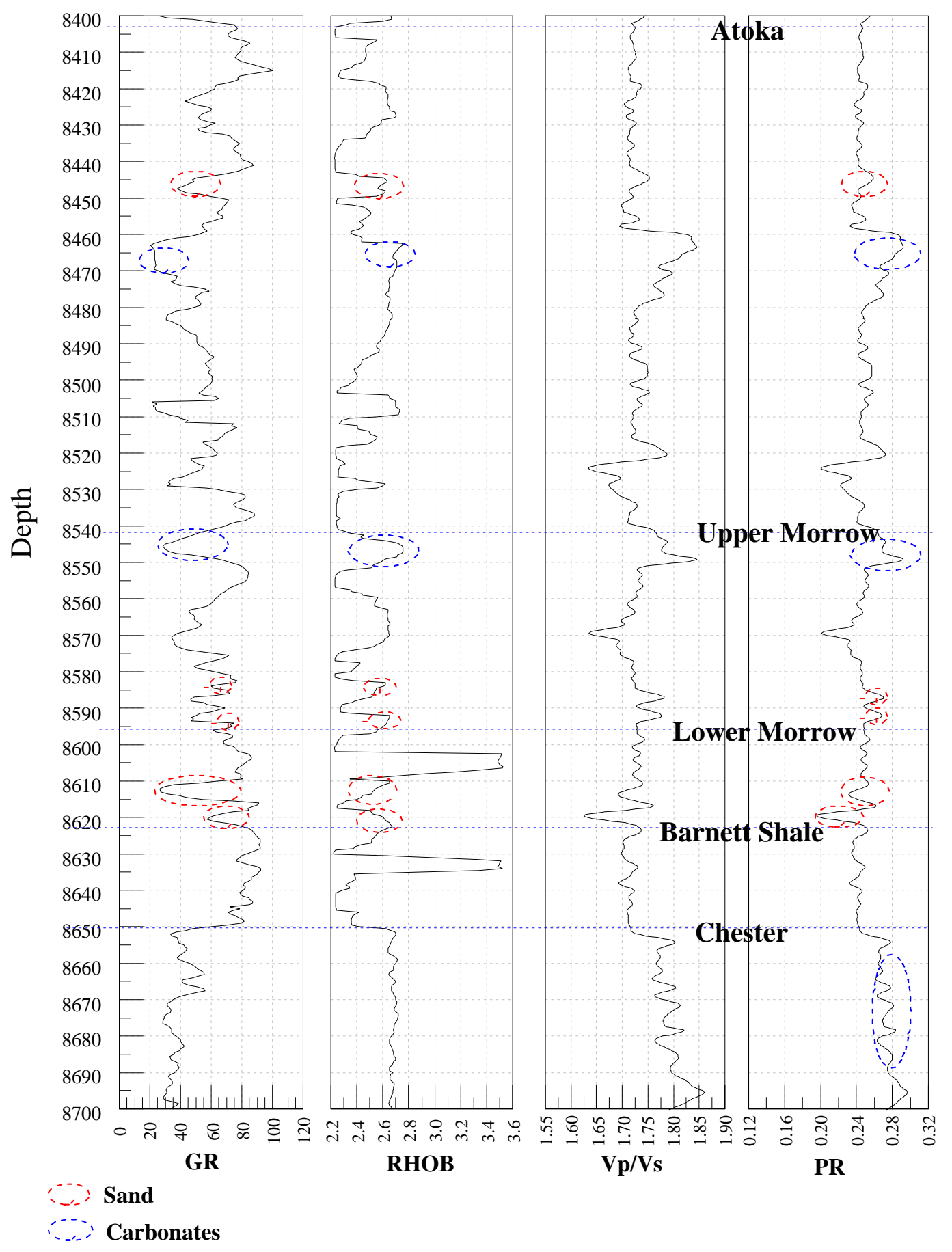

Figure 6.10: Derived Vp/Vs ratio and Poisson's ratio (PR) logs from the $\mathrm{P}$ and PS-wave velocity logs in the Lula 3 well. The gamma ray (GR) and Density (RHOB) logs are displayed to help distinguish the sand vs. shale and sand vs. carbonates. 


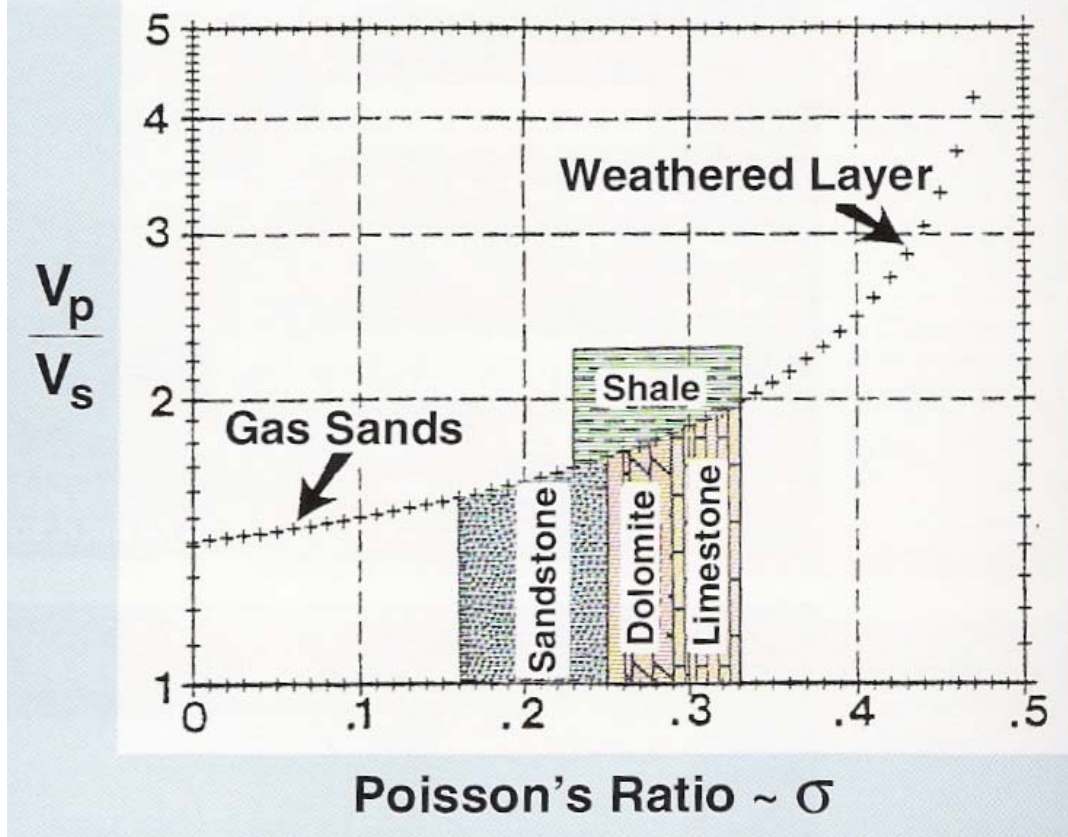

Figure 6.11: Poisson's ratios for clastic sediments ranging from near-surface weathered zones to gas sands are shown versus Vp/Vs ratio. Poisson's ratios are typically concentrated in the range 0 to 0.5 . Taken from Hilterman (2001).

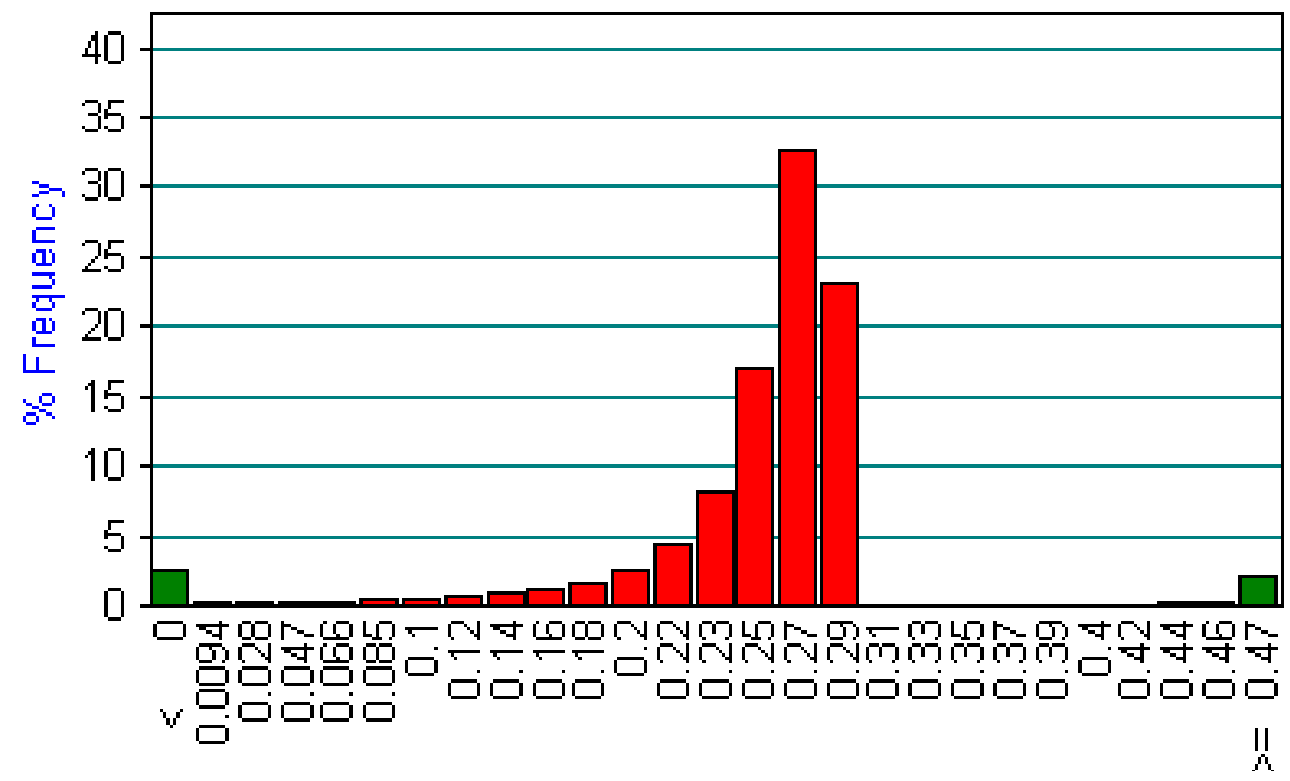

Figure 6.12: Histogram of Poisson's ratios after scaling. Data less than 0 and greater than 0.47 have been excluded. 
The scaled data were compared to the unscaled data to demonstrate the result of the scaling process (Figure 6.13). A single seismic trace was extracted from both, scaled and unscaled data. In the comparison trace, values prior to scaling (Figure 6.13a) range from approximately -0.95 to 0.4 ; after scaling the range extends approximately from 0.09 to 0.34 . Figure 6.13 illustrates that the relative variation in value (curve shape) remains unchanged; only the range has been changed.

Once Poisson's ratios were rescaled, the potential lithologic significance of the Poisson's ratio distribution within the 3D survey could be considered. The initial step in this process was to identify the relationship between Poisson's ratio and lithology observed in the Lula 3 well.

Based on the well log response (Figure 6.10), the Poisson's ratios vary from 0.2 to 0.27 for sandstones and 0.27 to 0.3 for carbonates. Higher values near 0.27 in the sand range may be associated with compact and calcareous sands. Poisson's ratios for the carbonates ranged from 0.27 to 0.3 in Figure 6.9. Poisson's ratios for shale ranged from 0.23 to 0.3. Dvorkin et.al (2003) report obtaining slightly higher values of Poisson’s ratios from the seismic inversion cubes. In their study, they obtained a Poisson's ratio of 0.31 for water sand from the inverted P-wave impedance that was higher than that predicted at log scale. In the approach developed here, we might expect to see similar disagreement or relative shift between the Poisson's ratio distribution derived from the seismic and that observed in well logs. This range will also be affected by Fresnel zone scale resolution limits and tuning as mentioned earlier. 


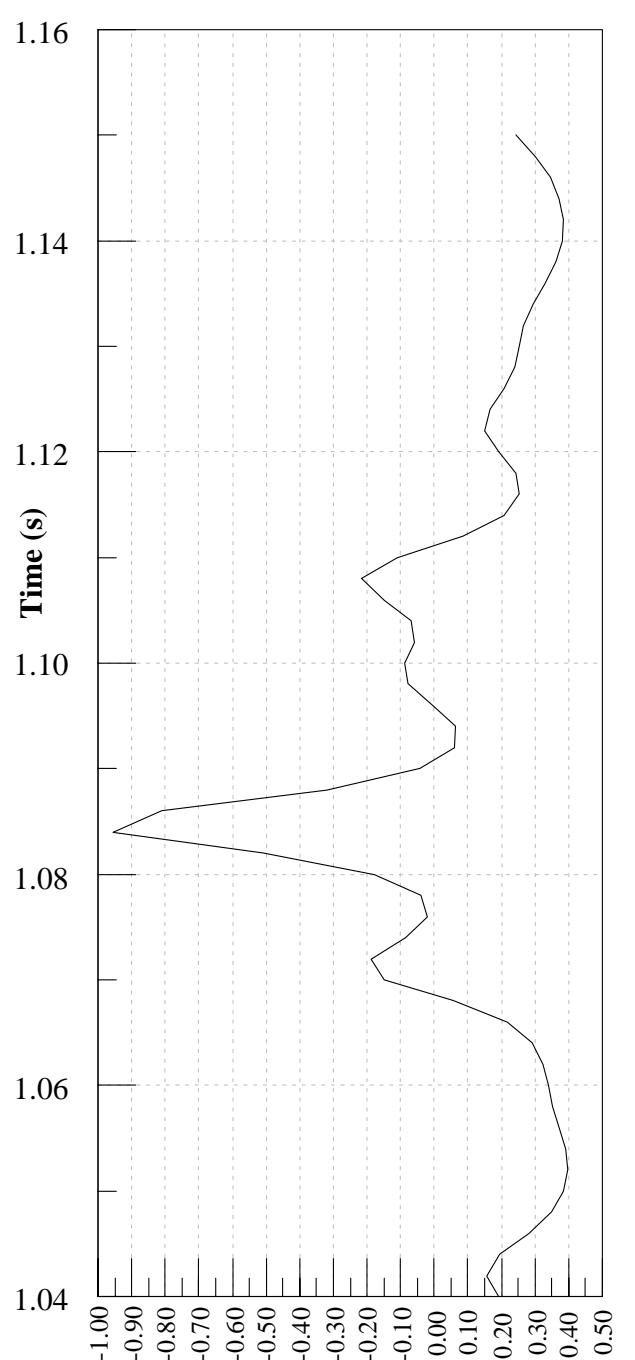

a)

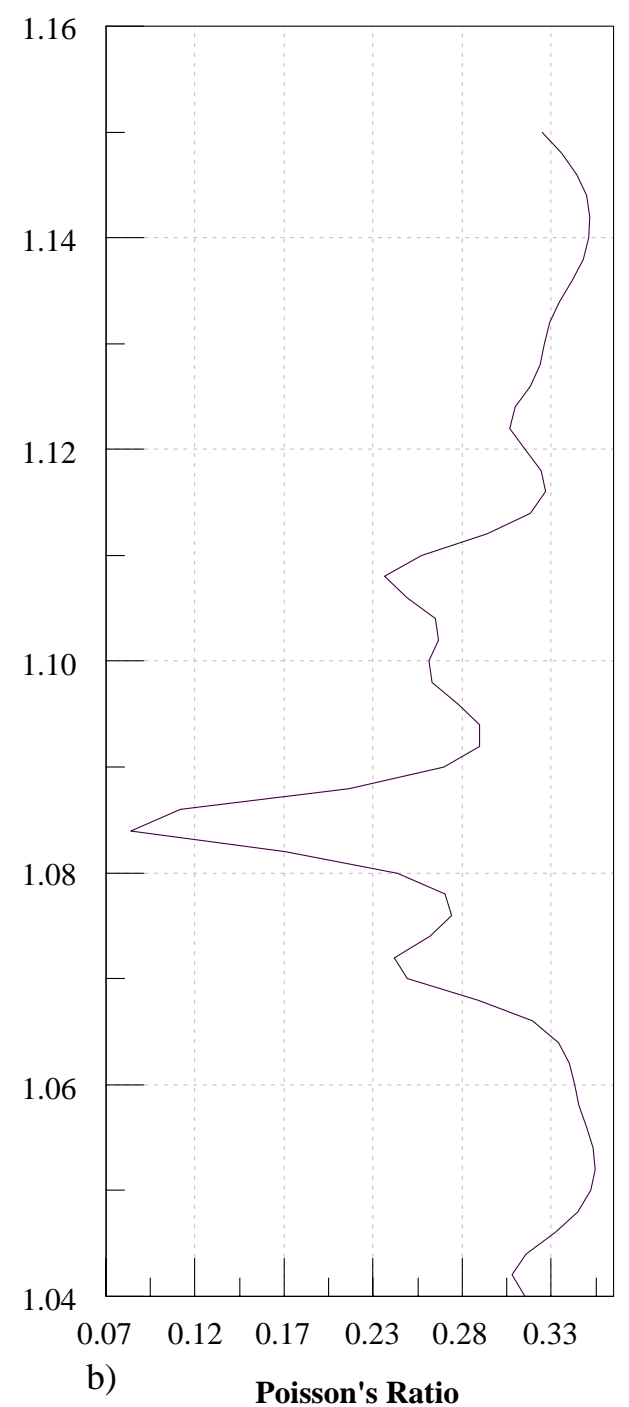

b)

Poisson's Ratio

Figure 6.13: A trace from the 3D Poisson's ratio volume was extracted for comparison of the a) Pre-scaling and b) Post-scaling responses. 
The Poisson's ratio and $V_{p} / V_{s}$ ratio were averaged from 5 ms below the Morrow reflection event to $10 \mathrm{~ms}$ below the Morrow reflection event. This $5 \mathrm{~ms}$ interval was assumed to represent the lower Morrow. The averaged $\mathrm{V}_{\mathrm{p}} / \mathrm{V}_{\mathrm{s}}$ ratios were plotted against the averaged Poisson's ratio (Figure 6.14). The interpreted lithology is based on relationships observed in the Lula 3 well (Figure 6.9). The slope of the curve for sandstone is less steep compared to that in carbonate and shale region. The sandstone has $\mathrm{V}_{\mathrm{p}} / \mathrm{V}_{\mathrm{s}}$ ratios lying between 1.25 to 1.45 and Poisson's ratios between 0.2 and 0.27 . The higher Poisson's ratios in this range may represent compact and calcareous sands. The carbonate interval has Poisson's ratios varying from 0.27 to 0.3 . They have steeper slope and wider range of $\mathrm{V}_{\mathrm{p}} / \mathrm{V}_{\mathrm{s}}$ values in comparison to those associated with sands.

The lithologic relationships identified in Figure 6.9 provide the basis for a lithologic interpretation of Poisson's ratio distribution for the Morrow interval. Poisson's ratios were averaged in the window extending from $5 \mathrm{~ms}$ to $10 \mathrm{~ms}$ below the Morrow top (Figure 6.15). Sandstones are shown by red to yellowish red color in the map. The interpreted sandstone has Poisson's ratio greater than 0.2 and less than 0.27 and is represented by red to yellowish red colors. The spatial distribution of Poisson's ratios through the 3D survey area have a similar pattern to that observed for the acoustic impedances discussed in the Chapter 5 (see Figure 5.24). The 0.2 to 0.27 range of Poisson's ratios associated with sands extends along a narrow belt from the northwest into the central part of the field. Further to the south the pattern of sand distribution broadens across the southern part of the survey area. The outline of high production is overlain on the Poisson's ratio map and reveals a fair correlation with inferred sand 


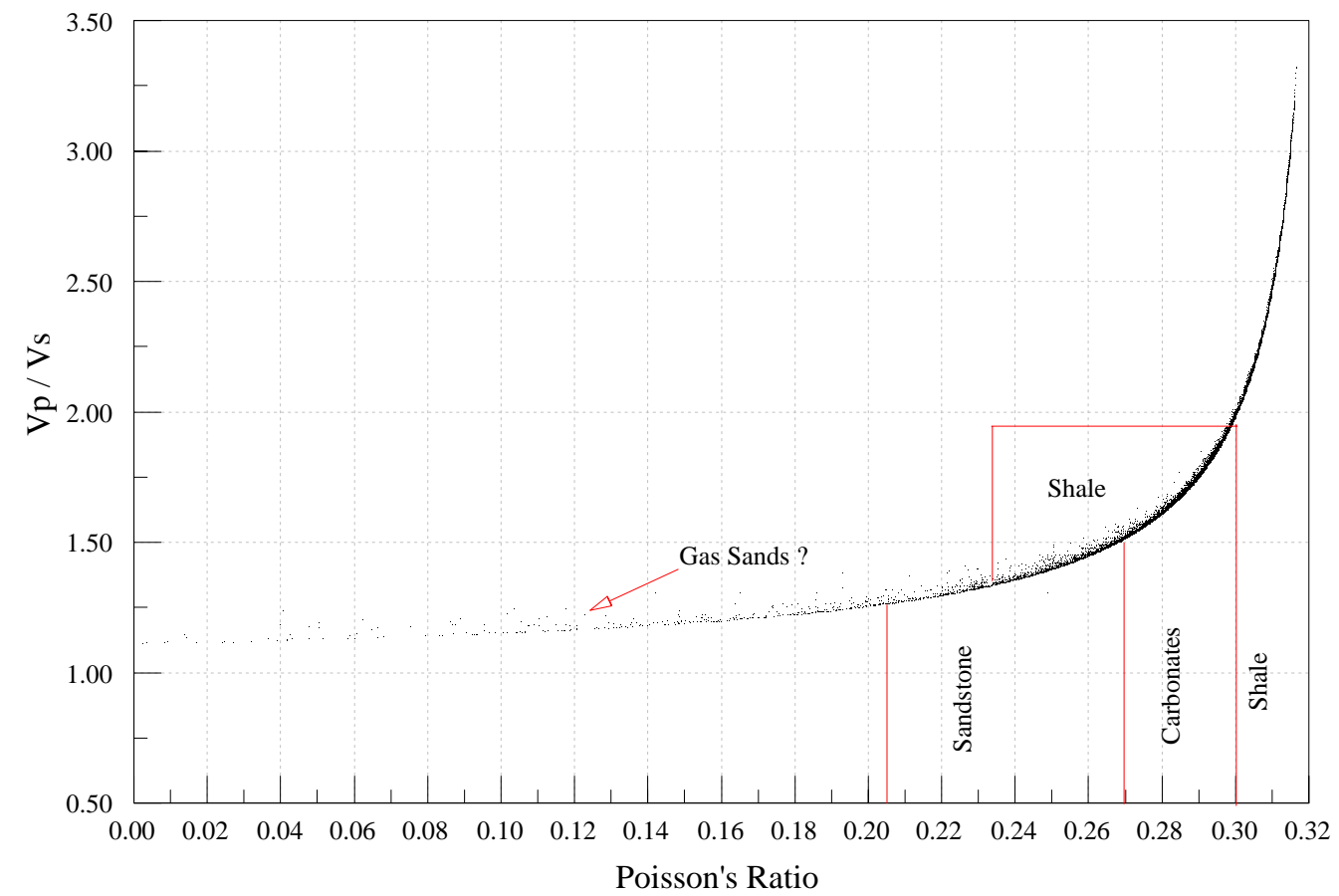

Figure 6.14: Poisson's ratio Vs. Vp/Vs ratio plot. The interpreted lithology boundaries are represented by the red lines.

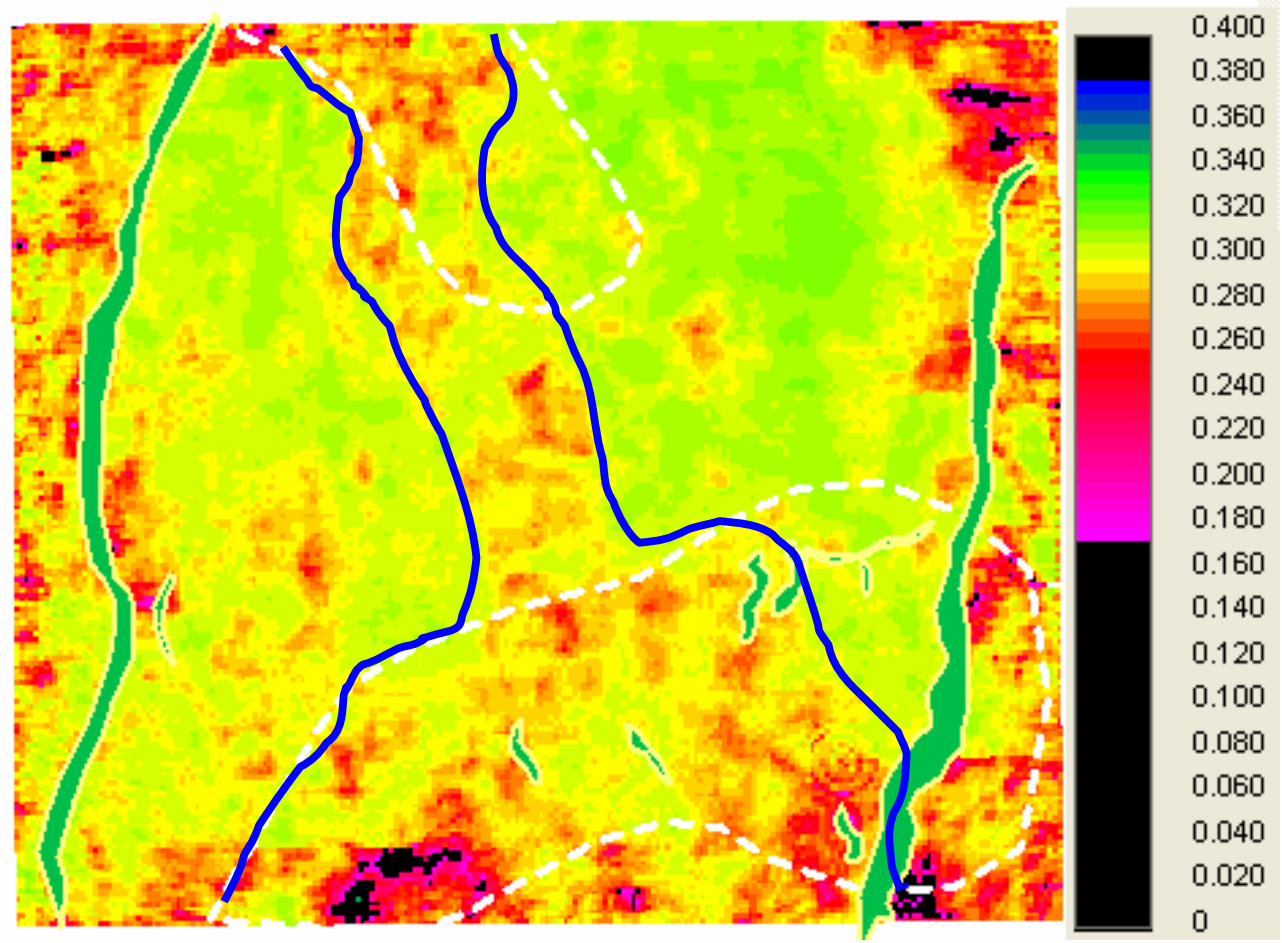

Figure 6.15: Average of the Poisson's ratio between 5-10 ms interval below the Morrow reflection event. Areas representing possible sands are red to yellowish red. 
distribution. As suggested above, the range of seismic derived ratios associated with a given lithology may vary due to a variety of factors: P-and PS-wave bandwidth, tuning, time shift between P- and PS-wave volumes, and Fresnel zone. The location of the Harris Channel seems to be better defined by Poisson's ratios in the 0.2 to 0.3 region (Figure 6.15). The distribution of carbonate environments would appear to have Poisson's ratios in the 0.3 to 0.34 range. Poisson's ratios associated with shale, overlap those of sand and carbonates so that shale zones mixed with sands and carbonates will not be differentiated.

Recursive inversion of P-wave and PS-wave seismic responses yields estimates of the respective P- and PS-wave acoustic impedances. Scaling of Poisson's ratios derived from P and PS wave impedances to those calculated from P and S wave sonic helps associate the seismic scale Poisson's ratios with specific lithology. Maps of average Poisson ratio derived from a window of data that includes the Harris Channel reveals a distribution of Poisson's ratios in the 0.2 to 0.3 range associated with the distribution of oil production in the field. This range of Poisson's ratios associated with a given lithology is likely to differ from those observed in the well log. The sand response appears to be bordered by regions of higher Poisson's ratio (0.3-0.34). These regions are interpreted to consist of shale and limestone. The representation of seismic response in terms of Poisson's ratios yields an interpretation that is consistent with interpretations derived from the P-wave data. The interpretation is enhanced by possible association to lithology in the depositional environment. 


\section{CONCLUSION}

The study provides a detailed analysis of the structural and stratigraphic controls on oil production form the Buffalo Valley field in southeastern New Mexico. Oil in the field is produced from the Harris Channel in the lower Morrow section of the lower Pennsylvanian. Although the reservoir trap is primarily stratigraphic, the heart of the Buffalo Valley field is bounded by steep faults along its eastern and western boundaries. The main focus of the study is centered on the analysis of 3D reflection seismic data from the field provided by WesternGeco. Data provided for the study included both P-wave and converted mode shear wave (PS-wave) 3D volumes. The main objective of the seismic interpretation was to determine whether the Harris Channel could be delineated seismically using P-wave and combined P- and PS-wave data sets. The study also incorporates regional and local well log correlation and mapping of the Mississippian through middle Permian strata that blanket the Northwestern Shelf area in which the field is developed.

The study area is located along the northern part of Eddy County and southern part of Chavez County, New Mexico. Geologically, the study area is situated on the Northwestern Shelf of the Delaware Basin. The primary zone of interest in the study is the lower Pennsylvanian Atoka-Morrow interval. The regional study reveals that the field develops in what appears to be a dropped block that trends nearly north-south across the northeast trending Northwest Shelf (see Figure 3.3).

Detailed mapping of lower Pennsylvanian Atoka-Morrow interval was difficult. The log responses from this interval varied considerably from well to well. The 
depositional environments in which these strata were formed consist of complex nearshore-deltaic depositional systems. These depositional systems are very heterogeneous at local scale, making well-to-well correlation difficult to establish.

Stratigraphically, the Morrow Formation is informally divided into lower, middle and upper Morrow intervals. The lower Morrow interval was deposited in a fluvialdeltaic environment while the middle and the upper Morrow intervals were deposited in near-shore marine environments. Sea level transgression occurred during deposition of middle and upper Morrow. As noted, oil production in the field is confined to a lower Morrow channel sand known as the Harris Channel. The sand is associated with a low gamma ray and high density response.

Analyses of structure and isopach maps were used to establish the regional setting of the Buffalo Valley field. Regional maps were constructed from the Mississippian Chester through the lower-middle Permian Glorietta Formation. These maps reveal that these upper Paleozoic strata dip southeast into the Delaware Basin and strike northeastsouthwest along the Shelf margin. The Chester-Atoka isopach map (Figure 3.17) reveals a belt of thickened section that rends roughly north-south through the field. This belt coincides with a structural low on the Chester (see Figure 3.8). The thickened Atoka-toChester section suggests syndepositional development of the Chester structure.

Two major north-south trending faults along the eastern and western margins of the field were interpreted to traverse the area. Strata up through the lower Permian Wolfcamp Formation show thickening along this northwest trend. During deposition of the Glorietta Formation the basin appears to have uplifted relative to the margin. The Glorietta thickens to the west and north across the Northwest Shelf. The structural 
framework of the field appears to have developed during deposition of the reservoir interval and overlying Pennsylvanian and lower Permian strata. The development of this structural low during deposition of reservoir strata may have controlled the course of the Harris Channel. The 5 year cumulative oil production from the lower Morrow reveals a roughly north-south production trend through the field, further suggesting concentration of channel development along this structural low. The regional production trend is roughly north-south, but it is likely that channel meanders will carry the channel across the margins of the structure.

The course of the Harris Channel through the field was also examined indirectly from the isopach map of the Barnett Shale. It was assumed that the channel scoured down into the Barnett Shale, thinning it along its course. An overlay of thinned Barnett Shale areas coincides well with the high production trend (see Figure 3.31). This association provides additional indirect evidence of the location of the Harris Channel.

Resolution limits for both P- and PS-wave data were evaluated to provide perspective on the horizontal and vertical scale of features likely to be imaged in the seismic data. Vertical resolution limits (tuning thickness) for the P- and PS-wave data are estimated to be $60 \mathrm{ft}$ and $68 \mathrm{ft}$, respectively using interval velocity characteristics of the Morrow channel sand. Fresnel zones in the P- and PS-wave data are estimated to have radii of $1055 \mathrm{ft}$ and $1122 \mathrm{ft}$, respectively. The Morrow channel sands vary in thickness from about 5 to $30 \mathrm{ft}$. Although the Harris Channel is below the resolution limit the amplitude of reflections from the channel may be detectable or produce significant influence on amplitudes of composite reflection events arising from the lower Morrow strata. 
Interpretation of the 3D P-wave seismic data volume reveals that the field is bounded by steep north-south trending faults along its eastern and western borders. Net offset along these faults is down to the east. These faults were active during deposition of upper Mississippian through the lower Permian strata. Dip reversals along the length of these faults suggest these faults may have strike-slip origin. The nature of these faults is similar to those described by Hills along the western margin of the Delaware Basin, being steep and cutting from the Mississippian though the lower Wolfcamp Formation (lower Permian). The faults were active during the deposition of the Pennsylvanian and lower Permian interval. The seismic data provided a detailed view of field scale structure.

Isopach and isochron maps of the Atoka-Morrow interval show significant thickening to the southeast across the central block. Such thickening suggests differential subsidence into the Delaware Basin during the deposition of Atoka-Morrow interval.

The time structure on the top of the Cisco (top of the Pennsylvanian) shows similar structure to that of the underlying units with pronounced thickening to the southeast.

The structure and Isochron maps of the Morrow to the Wolfcamp formations (the Pennsylvanian age sections) show eastward dip into the Delaware Basin being interrupted by abrupt steps across the western boundary fault. The structural relief across the western boundary fault also progressively decreases through the Pennsylvanian into the lower Permian Wolfcamp. Significant thickening across the boundary fault suggests these faults were active during deposition of the Pennsylvanian and lower Permian strata. However, during Wolfcamp, sediments over the central block thickened to the west (Figure 5.17) 
suggesting that the central block rotated to the west along the western boundary fault during the Wolfcampian time.

Isopach of the top of the Glorietta to top of the Wolfcamp reveals that middle Permian strata thicken to the north and west across the field. This thickening although not clearly related to movements along the boundary faults suggests the central block dropped to the north-northwest during this time representing inversion of earlier block motion.

Seismic attributes provided some insights into the relationship of seismic response to oil production and channel sand distribution within the Buffalo Valley field. Calculation of seismic attributes and averaging within a time window that includes the lower Morrow channel sand revealed distinctive north-south trend similar to the oil production trend. Integrated amplitudes in a $20 \mathrm{~ms}$ window of data from the lower Morrow (Figure 5.23) were high along a zone that coincide roughly with the oil production trend in the field. Similarly, RMS of P-wave in a window of data extending from $10 \mathrm{~ms}$ below the Atoka event to 9 ms below the Morrow event (Figure 5.24) also showed some association to the oil production trend.

This study also includes analysis of combined P and PS wave acoustic impedance volumes. Recursive inversions of the P- and PS-wave data were used to estimate P and S wave acoustic impedance. The ratio of these two volumes yields a $V_{p} / V_{s}$ ratio which can then be transformed into Poisson's ratio. The range of Poisson's ratios obtained in this process extended well beyond the expected range of Poisson's ratios of 0 to 0.5 . The majority of values were clustered in the -1.1 to 0.5 range with a distribution that looks much like the distribution normally associated with Poisson's ratios for limestone, shale, 
and sandstone. There are several sources of possible error that need to be explored in future studies of the data. These include errors in the conversion of PS-wave travel times to P-wave travel times, the effects of tuning on relative amplitude differences, and the variations in bandwidth between the P- and PS-wave data sets.

P- and S-wave velocities obtained from the Lula 3 well were used to calibrate Poisson's ratios to lithology (see figures 6.9 and 6.10). Using this as a guide, the Poisson's ratio distribution obtained from the combined 3D P- and PS-wave inversions were transformed into the range of Poisson's ratios calculated from the well log.

Amplitudes of reflection events in the P- and PS-wave data sets will be proportional to P- and PS-wave reflection coefficients only for isolated reflection events. In general this is not the case; the geology is often complex and reflection events are a composite of overlapping reflections. At Buffalo Valley the stratigraphy is heterogeneous at scales less than the vertical and horizontal resolution limits of the data. Isolated reflection events are not common in this data set.

Within the context of these limitations and possibilities for error, $\mathrm{Vp} / \mathrm{Vs}$ ratios and Poisson's ratios derived from the combination of 3D volumes may have limited direct relationship to these physical properties. However, the computations presented in this study represent a method for combining the P- and PS-wave seismic responses into a single attribute that has potential lithologic significance. The spatial distribution of the Poisson attribute (see Figure 6.15) shows some association to the distribution of oil production mapped in the field and stands as a seismic feature that might be used to locate additional wells within the field. The rough coincidence of Barnett Shale thinning, 
high production and Poisson's ratios in the sand range supports a lithologic interpretation of the seismic derived Poisson's ratio.

This combined well log and 3D seismic interpretation indicates that the early Pennsylvanian Harris Channel was guided through a structural low associated with syndepositional movement along steeply dipping faults that border the field (see Figure 5.9). Thickened areas in the Morrow isopach show some association to the distribution of oil production. Productive channel sands are thin and spatially heterogeneous within the context of seismic resolution limits. Their presence is not easily inferred from the seismic response. Integrated amplitude and RMS acoustic impedance in time windows that straddle the Morrow interval yield show some association to the distribution of high producing areas in the field and to the inferred course of the Harris Channel. Lower Morrow Vp/Vs and Poisson's ratio distributions obtained from the combined P-wave and PS-wave volumes define potential sand dominated areas that also coincide roughly with the major production trends in the field. The results of this study provide a basis for regional exploration and field-scale development of lower Morrow channel sand plays along the Northwestern Shelf of the Delaware Basin. 


\section{REFERENCES}

Allen, P.A. and Allen, J.R., 1990, Basin Analysis: Principles and Applications. Blackwell Science Limited, 440 p.

Bacon, M., Simm, R., and Redshaw, T., 2003, 3-D seismic interpretation. Cambridge University Press, pp. 102-119.

Badley, M.E., 1985, Practical Seismic Interpretation: International Human Resources Development Corporation, Boston, P. 264.

Casavant, R.R., 1999, Speculations on Basement tectonics: Insights from the White City Penn gas field, Eddy County, New Mexico., in R. E. Worthington and M. Brown, eds., A symposium of the oil and gas fields of southeastern New Mexico, 1999 supplement, Pennsylvanian gas fields: Roswell Geological Society, pp. 25-53.

Casavant, R.R., and Mallon, K.M., 1999, Facies and Reservoir characterization of the Morrow sandstones, White City Penn gas pool, Eddy County, New Mexico., in R. E. Worthington and M. Brown, eds., A symposium of the oil and gas fields of southeastern New Mexico, 1999 supplement, Pennsylvanian gas fields: Roswell Geological Society, pp. 55-96.

DeAngelo, M.V., Backus, B.,Murray, P., 1996, Depth registration of P-wave and C-wave seismic data for shallow marine sediment characterization, Gulf of Mexico. The Leading Edge, February 2003.

Dutton, S., Kim, E., Broadhead, R., Breton, C., Raatz,, W., Ruppel, S., and Kerans, C., 2004, Play Analysis and Digital Portfolio of Major Oil Reservoirs in the Permian Basin: Application and Transfer of Advanced Geological and Engineering Technologies for Incremental Production Opportunities: Final Report to DOE of work performed under DE-FC26-02NT15131, prepared by the Texas Bureau of Economic Geology and the New Mexico Bureau of Geology and Mineral Resources, P. 428.

Dvorkin, J., Fasnacht, T., Uden, R., Smith, M., Derzhi, N., and Walls, J., 1997. Rock physics diagnostics for porosity and lithology mapping in NE GOM. Stanford 
University, Anadarko Petroleum Corporation, and Rock Solid Images.

Galley, J.E., 1968. Some principles of tectonics in the Permian Basin. Basins of the Southwest, V. 1 -- AAPG, SW Sec., 10th Ann. Meeting, pp. 5-20.

Hanagan, M., 2003, Overview of 3D seismic-based siluro-devonian exploration efforts in Chaves county, New Mexico. Adapted from Transactions, AAPG SW Sec., Ruidoso, New Mexico, June 2002. Retrieved from technical publication database hosted by Petris Technology. http://www.searchanddiscovery.com/documents/2003/hanagan/index.htm.

Harding, T.P., and Lowell, J.D., 1979, Structural styles, their plate-tectonic habitats, and hydrocarbon traps in petroleum provinces. AAPG bulletin, 63(7), pp. 1016-1058.

Hills, J.M., 1970, Late Paleozoic structural directions in southern Permian Basin, West Texas and Southeastern New Mexico. AAPG bulletin, 54(10), pp. 1809-1827.

Hills, John M., 1984, Sedimentation, tectonism, and hydrocarbon generation in Delaware Basin, West Texas and Southeastern New Mexico. AAPG bulletin 68(3), pp. 250267.

Hilterman, F., J., 2001, Seismic Amplitude interpretation: 2001 Distinguished Instructor Short Course. Society of Exploration Geophysicists, 236p.

Hilterman, F.J., and Liang, L.C., 1983, Seismic Exploration Modeling Course, November 9-10, 1983, Singapore, Geophysical Development Corporation, pp. A9-A10.

Hoffman, J., 1008, Illumination, resolution, and image quality of PP- and PS-waves for survey planning. The Leading Edge, September, 2001.

James, A.D., 1984, Lower Pennsylvanian reservoirs of the Parkway-Empire south field area, Eddy county, New Mexico. West Texas Geological Society, SWS-84-78, pp.33-52.

James, A.D., 1985, Producing Characteristics and Depositional Environments of Lower Pennsylvanian Reservoirs, Parkway-Empire South Area, Eddy County, New Mexico. AAPG bulletin, 69(7), pp. 1043-1063.

Kallweit, R.S., and Wood, L.C., 1982, The limits of resolution of zero-phase wavelets. Geophysics, 47(7), pp. 1035-1046. 
Koefoed, O., 1955, On the effect of Poisson's ratios of rock strata on the reflection coefficients of plane waves. Eighth meeting of the European Association of Exploration Geophysicist may 18-20, pp. 381-387.

Kottlowski, F.E., 1968, Influence of Pedernal uplift on sedimentation, Basins of the Southwest, V. 1 -- AAPG, SW Sec., 10th Ann. Meeting, pp. 21-40.

Leiphart, D.J., Hart, B.S., 2001, Comparison of linear regression and probabilistic neural network to predict porosity from 3-D seismic attributes in Lower Brushy Canyon channeled sandstone, southeast New Mexico, Geophysics, 66(5), pp. 1349-1358.

Mazzullo, L.J., 1999, Significance of Intraformational Unconformities in the Morrow Formation of the Permian Basin. West Texas Geological society, vol.99-106, pp.55-61.

Mazzullo, S.J., 1995, Permian stratigraphy and facies, Permian Basin ( Texas- New Mexico) and adjoining areas in the mid-continent United states, Department of Geology, Wichita State University, Wichita, Kansas 67260, pp. 41- 59.

Montogomery, S.L, Worral, J., Hamilton, D., 2000, Delaware Mountain Group, West Texas and Southeastern New Mexico, A case of profound opportunity: part 1Brushy Canyon, AAPG bulletin, 83 (12), pp. 1901-1926.

Neidell, N., and Pogglagliolmi, E., 1977, Stratigraphic modeling and interpretation geophysical principles and techniques: in C. E. Payton, ed., Seismic stratigraphy applications to hydrocarbon exploration. AAPG Memoir 26, pp. 389 - 416.

Okaya, D.A., 1995, Spectral properties of the earth's contribution to seismic resolution. Geophysics, 60(1), pp. 241-251.

Ota, S., 2001, Integrated 3-D seismic analysis of Atoka Formation sandstone reservoirs, Vacuum Field Vicinity, Lea County, New Mexico. MS. Thesis, New Mexico Institute of Mining and Technology.

Pyakurel, S., Wilson, T., Toro, J., and Mohagheg, S., 2004, Interpretation of 3D seismic and subsurface data from the Buffalo Valley field, Chavez County, New Mexico: Geological Society of America Annual Meeting, Denver, CO.

Russell, B.H., 1988, Introduction to Seismic Inversion Methods: Course Notes Series, Volume 2, Society of Exploration Geophysicists, pp. 3-9. 
Sanchez, A., 2004, 3D Seismic Interpretation and Synthetic Modeling of the Atoka And Morrow Formations, in the Buffalo Valley Field (Delaware Basin, N.M, Chaves Co.) for Reservoir Characterization Using Neural Networks. M.S. Thesis, West Virginia University.

Shumaker, R.C., 1992, Paleozoic structure of the central basin uplift and adjacent Delaware basin, West Texas. AAPG bulletin, 46 (11), pp. 1804-1824.

Sheriff, R., 1977, Limitations on resolution of seismic reflections and geologic detail derivable from them: in C. E. Payton, ed., Seismic stratigraphy - applications to hydrocarbon exploration: AAPG Memoir 26, pp. 3-14.

Sheriff, R.E., Aspects of Seismic Resolution, University of Houston, Houston, Texas. pp. $1-10$.

Stewart, R.R., Gaiser, J.E., Brown, R.J., and Lawton, D.C., 2003, Converted-shear wave seismic exploration: methods. Geophysics, 67, pp. 1348-1363.

Stewart, R.R., Gaiser, J.E., Brown, R.J., and Lawton, D.C., 2003, Converted-shear wave seismic exploration: applications. Geophysics, 68, pp. 40-57.

Taner, T. M., 2001, Seismic Attributes, Rock Solid Images, Houston, U.S.A., pp. 49-56.

VanDok, R., Gaiser, J., Western, 2001, Stratigraphic description of the Morrow Formation using mode-converted shear waves: Interpretation tools and techniques for three land surveys. The Leading Edge, September, pp.1042-1047.

Viele, G.W., and Thomas, W.A, 1989, Tectonic synthesis of the Ouachita orogenic belt, in Hatcher, R.D., Jr., Thomas, W.A., and Viele, G.W., eds., The Geology of the North America, Volume F-2, The Appalachian-Ouachita Orogen in the United states: Geological society of America.

Widess, M.B., 1973, How thin is a thin bed. Geophysics, 38(6), pp. 1176-1180.

Wilson, T. H., 2002: Lecture Notes: Geology 554: Environment and Exploration Geophysics II, Department of Geology and Geography, West Virginia University.

Wilson, T.H., and Pyakurel, S., 2005, An intelligent systems approach to reservoir characterization: Task 1: Geophysics, Final report from Department of Geology and Geography to the U.S. Department of Energy National Energy Technology 
Laboratory.

Worthington, R., 1999, Shugart North (Morrow), in R. E. Worthington and M. Brown, eds., A symposium of the oil and gas fields of southeastern New Mexico, 1999 supplement, Pennsylvanian gas fields: Roswell Geological Society, 247 p.

Yang, K., Dorobek, S.L, 1995, The Permian basin of west Texas and new Mexico: Tectonic history of a "composite” foreland basin and its effects on stratigraphic development, in Dorobek, S.L., and Ross, G.M., eds., Stratigraphic Evolution of Foreland Basins: Tulsa, OK, SEPM Special Publication No. 52, pp. 147-172.

Yang, Kenn-Ming; Dorobek, S.L., 1992, Mechanisms for late Paleozoic synorogenic subsidence of the Midland and Delaware basins, Permian Basin, Texas and New Mexico, West Texas Geological Society, 92-91, pp.45-60. 